\author{
Universidade de São Paulo \\ Faculdade de Saúde Pública
}

\title{
SAÚDE COLETIVA E SUS: análise sobre as mútuas influências entre o campo e o sistema de saúde no Brasil
}

\section{Mariana Bertol Leal}

Tese de Doutorado apresentada ao Programa de Pós-Graduação em Saúde Pública da Faculdade de Saúde Pública da USP para obtenção do título de Doutora em Ciências.

Área de Concentração: Prática de Saúde Pública

Orientadora: Dra. Laura Camargo Macruz

Feuerwerker

São Paulo

2015 


\title{
SAÚDE COLETIVA E SUS: análise sobre as mútuas influências entre o campo e o sistema de saúde no Brasil
}

\author{
Mariana Bertol Leal
}

Tese de Doutorado apresentada ao Programa de Pós-Graduação em Saúde Pública da Faculdade de Saúde Pública da USP para obtenção do título de Doutora em Ciências.

Área de Concentração: Prática de Saúde Pública

Orientadora: Dra. Laura Camargo Macruz

Feuerwerker

\section{Versão Original \\ São Paulo \\ 2015}


É expressamente proibida a comercialização deste documento, tanto na forma impressa como eletrônica. Sua reprodução total ou parcial é permitida exclusivamente para fins acadêmicos e científicos, desde que, na reprodução, figure a identificação do autor, título, instituição e ano da tese. 
Meu esforço ao longo dessa produção foi motivado pelo desejo de que a ciência produza conhecimentos de utilidade pública e que seja possível qualificar a saúde, o campo da Saúde Coletiva e o SUS no Brasil. Por isso, dedico ao meu país e ao povo brasileiro que me inspirou a questionar a ciência e a política com o objetivo de dar pistas sobre o que ainda pode melhorar. Dedico a todos que me apoiaram, de alguma forma, a estudar em instituições públicas, como é o caso da Universidade de São Paulo, e tornaram essa produção possível. A todos vocês (pessoas e instituições) eu dedico essa tese@! 


\section{AGRADECIMENTOS}

Agradeço aos afetos e as conexões que eles produzem!

O caminhar desse doutorado foi cheio de escolhas, de frustrações, de alegrias, de encontros, de choros, de aprendizados, de altos e baixos... foi intenso e afetuoso! E no final desse caminhar, quero agradecer aos afetos, os mais felizes e aos mais tristes, aos mais vivos e aos menos presentes, agradeço a possibilidade de ter vivido tudo e, agora, ser alguém melhor, com mais maturidade e com mais força para lutar pelo que acredito e pelo que acho justo!

Os afetos produziram conexões incríveis e me desestabilizaram assim como me reconectaram, eles foram essenciais para o caminhar ter acontecido passo a passo!

Por isso, começo agradecendo ao começo de tudo: meus pais, meus grandes incentivadores, educadores, os quais sempre foram presença acolhedora e estimuladora na minha vida. Sempre me deram apoio em todos os vôos que dei. Obrigada por não terem me deixado desistir e desacreditar que era possível sempre fazer mais!

Agradeço a família onde cresci! Em especial à minha avó Heloy que, com 91 anos, me inspira, sempre reza e acredita que podemos sonhar e conquistar mais!

Agradeço especialmente as minhas crianças! Minhas afilhadas Ísis, Clara e Yara, que me dão alegria e que mobilizam a minha criança! Ao meu amado sobrinho Marcos que me desafia a ser uma tia/mãe a cada dia e que me fala que sou a melhor tia do mundo! E aos outros pequenos que iluminam minha vida e alegram meu coração: Giovana, Olívia, Sofia, Davi, Chico, Cecília, Lucas, Bia, Ana Victória, Gabriel. Aos recém-chegados Martin e Stella e aos que estão quase chegando para trazer ainda mais vida para meus dias!

Agradeço a minha companheira de madrugadas de estudo e que, com seu olhar e presença constante, deixava minha alma mais leve e meu coração mais cheio de amor, minha Naná! Agradeço a família que conquistei, queridos amigos que fizeram cada dia menos difícil e mais alegres! Agradeço a Liu, a Silvia, a Manu, o Mateus, a Mari Leite, a Fernanda, a Dani, o Ricardo, a Aline, a Gisélia, a Aninha, a Odete, a Liliana, o Estevão, o Osvaldo, a Andrea, a Lectícia, a Luzmarina, a Fabiana, a Emanuelly, o Carlos, a Dai, a Miriam, a Reis, a Lene, a Talita, a Vanessa, a Priscila, e a tantos outros que nesse momento de nervosismo com certeza esqueci de listar.

Faço um agradecimento especial à Liu, minha irmã, que, apesar dos tropeços e dos momentos de desentendimentos, foi parceira na produção desse doutorado na minha vida. A idéia começou com ela, com um plano de uma nova aposta para as nossas vidas. Vivemos intensamente e superamos tudo o que nos fez crescer e, mesmo, às vezes, distante, esteve presente e junto comigo. Obrigada! 
Também faço um agradecimento especial para minha amiga guerreira Odete porque sem ela não teria sido tão agradável esse caminhar nem sempre alegre. Ao compartilharmos nossos doutorados, compartilhamos amor e fé, acreditamos uma na outra e nos fortalecemos juntas nas nossas produções! Obrigada por tudo, pela companhia, pela casa, pelas pizzas e pela Cecília!

Agradeço aos que me ajudaram a ser a profissional que sou e que, de alguma forma, me ajudaram a conseguir prosseguir: a Maria Luiza e o Alcindo. Obrigada pelos conselhos, pelo apoio e por estarem por perto.

Agradeço as amigas que foram especialmente parceiras nessa produção: a Fabiana, a Karina e a Maria Luiza. Fundamentais nos últimos minutos do segundo tempo!

Agradeço a Lidiane e ao Pedro, casal amigo que me ajudou muito no final dessa produção com suas habilidades de programação de sistemas! Um obrigadão especial a família toda que esteve comigo durante algumas madrugadas!

Agradeço ao Fórum Nacional de Pós-Graduandos em Saúde e a Associação Nacional de Pós-Graduandos por, desde o meu mestrado, me propiciarem espaços e momentos de militância! Encontrar companheiros nessa caminhada que buscam construir uma política de educação e de ciência e tecnologia mais convergente com as necessidades do país foi fundamental para me animar em muitos momentos. Destaco o agradecimento aos companheiros Chicão, Pedro, David, Lúcia, Aninha e Manu.

Agradeço a Faculdade de Saúde Pública da USP por ter me acolhido vinda de longe e me propiciado muitos aprendizados.

Agradeço ainda ao meu país e ao povo brasileiro por apostarem na educação e no desenvolvimento da ciência e tecnologia. Parte dos impostos pagos, revertidos em disponibilidade de vagas em universidades públicas, me propiciou cursar esse doutorado, por isso, agradeço ao investimento.

Agradeço aos participantes da minha banca de qualificação que me ajudaram a repensar o projeto e a recortar a abrangência inicial. Alcindo, Emerson e Frazão.

Agradeço aos participantes da minha banca de defesa, por aceitarem o convite e por me possibilitarem pensar a partir de um novo olhar sobre minha produção. Vocês foram escolhidos justamente porque quero o diálogo que seja produtivo para problematizar o tema que tanto me mobilizou. Por isso, obrigada! Arthur que aceitou abrir uma brecha na sua agenda atribulada. Emerson pela presença afetuosa e crítica em vários momentos da minha formação. Ruben pela presença constante no meu caminhar. Cristina pelo encontro feliz. Também agradeço aos suplentes que ficaram a postos e foram parceiros para um olhar a mais: Débora, Marília, Tatiana, Marco e Oswaldo. 
E, agradeço especialmente a minha orientadora! Que foi mais do que orientadora, conselheira, companheira, amiga, Laura foi uma parceira incondicional! Entendeu meu tempo e meu movimento, respeitou minha opinião, me fez pensar e repensar, me colocou em análise, me agenciou a vontade de querer terminar essa produção, nunca deixou de acreditar que era um estudo interessante. Às vezes, acreditava mais do que eu! Tudo o que vivemos, os choros, as risadas, os aprendizados, os estudos, etc, etc, tudo foi muito importante! Laura, meu muito obrigada aqui é pouco mas simboliza o que senti ao longo desse processo. Uma grande parceria que nunca imaginei ter! Obrigada! Obrigada! E obrigada!

Aproveito e agradeço ao Pililico, filho felino da Laura, e que, em muitos encontros de orientação, noites compartilhadas, feriados, finais de semana e cafés da manhã, foi parceiro, esteve por perto, pedindo e dando carinho, sempre observando, sempre por perto! E agradeço, de forma especial, a três pessoas importantes na minha vida e que me deixaram durante o processo desse meu doutorado. A ausência repentina delas me agenciou um tremendo sofrimento e hoje a superação dele me faz enxergar o que ficou de bom apesar de tudo isso. Agradeço a minha avó Tita por ter acreditado em mim e por ter incentivado o encontro das primas que aconteceu quando fui morar em SP; agradeço por ter sido forte e por ter me ensinado muitas coisas inclusive com a sua teimosia. Agradeço a minha Tia Beth, minha segunda mãe, que nos deixou precocemente e que ainda faz falta. Tenho certeza de que estaria orgulhosa dessa sua filha emprestada. E, agradeço a minha grande amiga e parceira de trabalho, de família e de afeto baiano, Conceição Benigno. Ela me estimulou desde o início a deixar a Bahia para fazer esse doutorado e sempre arranjou um jeito de me manter por lá conectada. Acho que foi uma das pessoas que mais acreditou em mim e no meu potencial técnico e político, foi aquela pessoa que tinha toda confiança em mim. Ela foi alguém tão forte na minha vida, alguém que me fez aprender tanto e que sempre me desafiou a fazer o meu melhor. Sinto sua falta a cada dia e tenho certeza que estaria aqui vibrando comigo por essa produção.

Foram 3 grandes perdas, 3 grandes obras na casa dos meus pais, 3 anos com a minha casa guardada num depósito, 3 anos de retorno de saturno e 3 cidades/estados onde morei ao longo desse doutorado. Ah, também foram 3 países em que vivi algum tempo nesse período. Sobrevivi e hoje, por último, agradeço, então, aos astros que me trouxeram até aqui, que me viraram de cabeça para baixo durante o retorno de saturno, que me agenciaram o melhor e o pior de mim e que hoje me possibilitam superar e continuar a caminhar. Essa tese não é, ainda, um fim, é um dispositivo para mais e mais conversas e produções que ainda virão! 


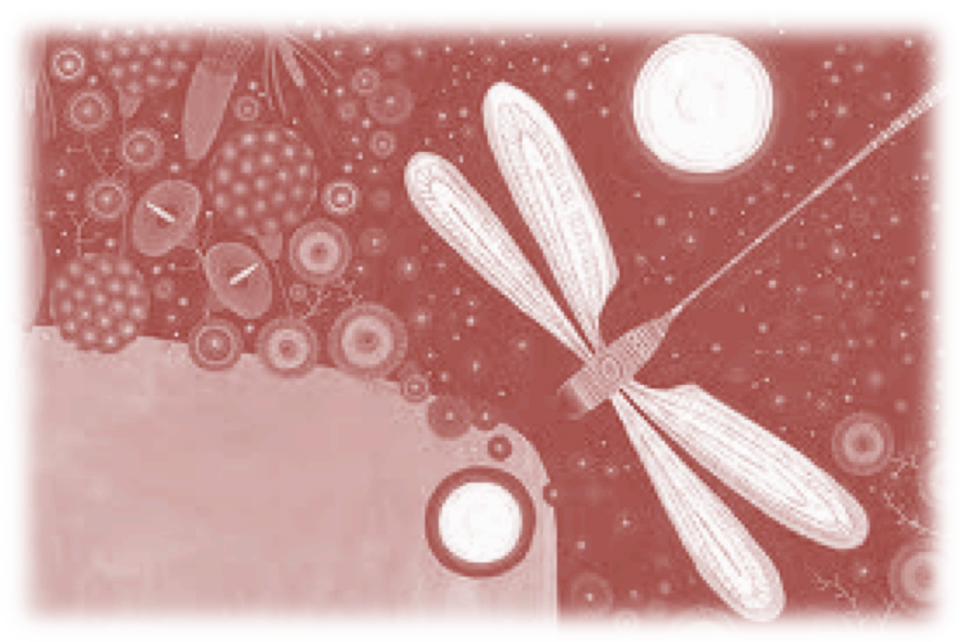

No Vietnã, tradicionalmente, a libélula é o símbolo da transformação e o processo constante de mudança da vida. Elas são excelentes voadoras, disparam como a luz e mudam de direção com rapidez.

Considerada uma mensageira, ela transita entre ar e água, transpassando as influências de ambos os elementos por onde passa.

Renovação, forças positivas e o poder da vida são as principais representações deste inseto.

Ao tocar leve e rapidamente a água, elas sugerem que nossos pensamentos mais profundos emergem, vêm à tona e que é preciso ir além da superfície e buscar as decorrências mais profundas dos aspectos da vida.

A sua agilidade e capacidade de se mover em todas as direções demonstram um poder de equilíbrio - o que só acontece na vida adulta da libélula, e para Neos, com a maturidade. Ela se movimenta pra frente, pra trás, paira, pra cima, pra baixo, para os lados, como o sopro da mente. $A$ vida é um sopro.

Dizem que as libélulas só vivem um dia, mas não é verdade, e se ela viveu um dia só, foi na sua vida adulta. A libélula vive a grande parte de sua vida como uma criança, imatura. Voar é apenas uma fração da sua vida e dura apenas alguns meses. Ao alçar vôo, ela já é adulta e o faz intensamente. Ela não tem tempo pra perder e nos lembra do poder do viver o momento e viver a vida ao máximo. Ela nos lembra que é vivendo o agora que você está em plena consciência de quem é, onde está, o que faz, o que quer e o que não quer

Elas simbolizam coragem, força e felicidade. Sorte a sua se um pousar em você. Os Vietnamitas prevêem as chuvas pela maneira como as libélulas voam - vôos baixos significam chuva chegando, vôos altos significam dias de sol.

Em Laos me ensinaram que a libélula representa três valores do Budismo Teravada: desapego (do stress) humildade (com seu entorno) efemeridade (do momento)

Então vamos viver com estes princípios, com vivacidade e sem arrependimentos, como uma libélula adulta.

Fonte: http://escapismogenuino.com/o-simbolismo-da-libelula/

As libélulas são seres presentes na minha vida em muitos momentos, e, sempre acredito que elas me trazem algum recado, me ajudam a pensar e a enxergar as coisas com mais serenidade e clareza! São seres de luz, que aparecem do nada e que muito me ajudaram a superar os desafios postos, inclusive para finalizar essa produção. 


\section{Resumo}

A Saúde Coletiva é um movimento político-ideológico-intelectual que se constituiu como campo de produção de conhecimento, de saberes e práticas, configurado pela intercessão entre as áreas específicas. Assim, o entredisciplinar é um conceito interessante para refletirmos sobre esse campo que se produz pelo encontro, para além das fronteiras. Tomando como contexto o campo da Saúde Coletiva no Brasil e o SUS, o estudo buscou analisar as interações e mútuas relações que se estabeleceram entre o campo e o Sistema Único de Saúde (SUS) a partir da identificação do movimento de produção das políticas de saúde e do movimento de produção do campo.

Para tanto foram pesquisados bancos de teses e dissertações de programas de Saúde Coletiva, artigos de 3 periódicos reconhecidos como relevantes e textos e documentos referentes às políticas. As políticas estudadas foram: atenção básica, educação na saúde e regionalização e organização do SUS.

A partir do conceito de política como dispositivo e do ciclo de análise de políticas proposto por Ball, foram investigados dois movimentos de produção de textos: os referentes à formulação das políticas e a produção acadêmica.

De maneira geral, pudemos notar que a agenda das políticas interfere na agenda das pesquisas, contudo, o que está sendo publicado não reflete o produto do que é produzido no campo e nem sempre dialoga com as necessidades do SUS.

Assim, existe uma mútua influência, mas não necessariamente no sentido da potência. Foram muitos os achados do estudo e é possível afirmar que, de modo geral, as questões que existem no SUS são pouco estudadas na Saúde Coletiva. As produções do campo dialogam mais com um movimento de afirmação das políticas e levantamento de algumas dificuldades e desafios para sua implementação e isso, justamente, não converge nem como o conceito de política a que esse estudo se refere. A política se produz a partir das relações e está em constante movimento de disputa, sendo assim, a micropolítica pode ser observada a todo momento e seria de muito utilidade para o SUS se o campo da Saúde Coletiva pudesse abrir mais algumas janelas e construir estratégias de investigação e formulação de novos conhecimentos que possam ser tão interessantes e militantes como os saberes que foram produzidos e afirmados 
durante o processo de construção do SUS de autoria desse campo de conhecimento e que agora precisa ser tencionado para se ressignificar.

Palavras-chave: política, Saúde Pública, Saúde Coletiva, Sistema Único de Saúde, análise, política de saúde 


\section{Abstract}

Public Health is a political-ideological movement that was formed as a field of knowledge production, knowledge and practices, configured by the intersection between the specific areas. Thus, the between-discipline is an interesting concept to reflect on this field that is produced by the encounter, beyond the borders. Taking as a scope the field of public health in Brazil and the SUS, the study investigates the interactions and mutual relations established between the Public Health field and the Unified Health System (SUS) based on the identification of the production of health policies movement and the field production movement.

To achieve that, theses and dissertations banks of Public Health programs, articles from 3 relevant periodicals, and texts and documents relating to these policies were researched. The policies studied were: primary care, health education, regionalization and SUS organization.

Based on the concept of politics, two text production movements were investigated: the ones related to the formulation of policies and the academic production.

In general, we may notice that the political agenda interferes in the research agenda. However, what is being published does not reflect the product of what is produced in the field and does not always dialogue with the SUS needs. Thus, there exists mutual influences but not necessarily related enhancements. The study had many findings and it is possible to affirm that, in general, the issues that exist in the SUS are understudied in Public Health. The productions of the field dialogue mostly with a policy statement movement and the raising of some difficulties and challenges in its implementation and that, precisely, does not converge with the concept of politics to which this study refers. Politics is produced based on relations and is constantly in a dispute movement, thus micropolitics can be observed at all times and it would be very useful to the SUS that the public health field could open a few more windows and build research strategies and development of new knowledge that could be as interesting and militant as the knowledges that were produced and affirmed during the SUS 
construction process created by this same field of knowledge and that now needs to be tensioned to resignify itself.

Keywords: Policy, Public Health, Unified Health System, analysis, health policy 


\section{Sumário}

A SAÚDE COLETIVA NO BRASIL: O CENÁRIO E OS PRESSUPOSTOS DO ESTUDO $\quad 24$

O TEMA ESTUDADO: $\quad 27$

PERGUNTA-CHAVE: $\quad 27$

OBJETIVOS

OBJETIVO GERAL:

OBJETIVOS ESPECÍFICOS:

OS VÔOS POR VÁRIAS DIREÇõES E OS PLANOS ANALÍTICOS DA PESQUISA: OS PASSOS DESENVOLVIDOS PARA VIABILIZAR O ESTUDO 28

CONTEXTUALIZAÇÃO E RESGATE DE FATOS RELEVANTES DO DESENVOLVIMENTO

DA SAÚDE PÚBLICA E DA SAÚDE COLETIVA NO BRASIL

MEDICINA: ALGUNS FATOS MARCANTES DESSA HISTÓRIA

UM DESTAQUE PARA A REFORMA SANITÁRIA NO BRASIL

O NASCIMENTO DA SAÚDE COLETIVA: CONFORMAÇÃO DE UM CAMPO ENGRAVIDADO PELA SAÚdE

PÚBLICA E PELA REFORMA SANITÁRIA BRASILEIRA

EFEITOS... COLATERAIS A PARTIR DO MERGULHO NOS BANCOS DE TESES E NOS

\begin{tabular}{ll} 
PERIÓDICOS & $\mathbf{5 7}$ \\
\hline
\end{tabular}

O ENCONTRO COM AS PALAVRAS-CHAVE

O PROCESSO DE CONSTRUÇÃO DAS CATEGORIAS TEMÁTICAS

A METODOLOGIA DE ANÁLISE DE POLÍTICAS E A DEFINIÇÃO DO OLHAR A PARTIR DO

ENTENDIMENTO DA POLÍTICA COMO DISPOSITIVO

A PARTIR DO OLHAR SOBRE A PRODUÇÃO DAS POLÍTICAS: PONTOS DE

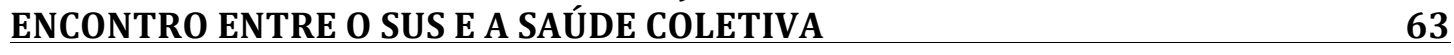

A ESCOLHA DE UMA PERSPECTIVA PARA O OLHAR SOBRE A PRODUÇÃO DAS POLÍTICAS 63 UM OLHAR DIRECIONADO AOS TEXTOS OFICIAIS DAS POLÍTICAS

SOBRE OS ENCONTROS: ALGUMAS REFLEXÕES SOBRE AS POLÍTICAS E SEU PAPEL $\begin{array}{lr}\text { DISPOSITIVO NO SUS } & \mathbf{8 4}\end{array}$

UM OLHAR DIRECIONADO AOS TEXTOS PRODUZIDOS SOBRE A POLÍTICA DE ATENÇ̃̃o BÁSICA 84 UM OLHAR DIRECIONADO AOS TEXTOS PRODUZIDOS SOBRE A POLÍTICA DE REGIONALIZAÇÃO E

ORGANIZAÇÃO DO SUS

UM OLHAR DIRECIONADO AOS TEXTOS PRODUZIDOS SOBRE A POLÍTICA DE EDUCAÇÃO NA SAÚDE

O OLHAR SOBRE AS PRODUÇÕES: ENCONTROS E DESENCONTROS NO CAMPO DA SAÚDE COLETIVA

UM OLHAR GERAL PARA O CENÁRIO doS PROGRAMAS DE Pós-GraduaÇÃo 153

UM OLHAR GERAL PARA OS PERIÓDICOS

UM OLHAR PARA AS POLÍTICAS DE SAÚDE SELECIONADAS E SEUS ENCONTROS COM A CADEIA PRODUTIVA DO CONHECIMENTO DO CAMPO DA SAÚDE COLETIVA POLÍTICA DE ATENÇ̃̃̃O BÁSICA 
DISCUSSÃO: MÚTUAS INFLUÊNCIAS ENTRE O SUS E A SAÚDE COLETIVA NO BRASIL 196

UM POUCO SOBRE DIÁLOGOS ENTRE O SUS E A SAÚDE COLETIVA 196

MÚTUAS INFLUÊNCIAS. MÚTUAS INSUFICIÊNCIAS 196

O SUS QUE FABRICAMOS TEM A VER COM O SUS QUE DIZEMOS QUERER?

OS MODELOS TECNOASSISTENCIAIS E A DISPUTA PELO CONCEITO E PRÁTICAS DE SAÚDE 200

E A SAÚDE COLETIVA CONTINUA SUSTENTANDO OS COMPROMISSOS QUE A INAUGURARAM COMO

CAMPO DE SABERS E PRÁTICAS? $\quad 204$

PENSANDO NA ANÁLISE DE POLÍTICAS $\quad 206$

\begin{tabular}{lr} 
REFERENNCIAS & 209 \\
\hline
\end{tabular}

ANEXO 1: PARECER DO COEP/FSP/USP

ANEXO 2: PÁGINA INICIAL DO CURRÍCULO LATTES DA AUTORA 223

ANEXO 3: PÁGINA INICIAL DO CURRÍCULO LATTES DA ORIENTADORA $\quad 224$ 


\section{Lista de Tabelas}

Tabela 1: Distribuição dos trabalhos segundo data de início do banco on line, número total de trabalhos e número de trabalhos selecionados

Tabela 2: Distribuição dos trabalhos selecionados segundo programa e grau acadêmico

Tabela 3: Distribuição dos trabalhos selecionados por ano de produção e grau acadêmico

Tabela 4: Lista das categorias e sub-categorias temáticas utilizadas para a categorização dos dados das produções do campo da Saúde Coletiva selecionadas Tabela 5: Distribuição dos artigos segundo data de início do banco on line e número de artigos selecionados

Tabela 6: Distribuição dos artigos selecionados segundo periódico e tipo de produção

Tabela 7: Distribuição dos artigos selecionados por ano e tipo de produção

Tabela 8: Seleção de Palavras-chave e idéias-chave, Descritores e Possíveis classificações segundo grandes áreas de debate

Tabela 9: Palavras-chave, categorias utilizadas na pesquisa e termos utilizados igualmente em ambas as classificações

Tabela 10: Descritores, descritores semelhantes as categorias temáticas, palavras-chave semelhantes aos descritores

Tabela 11: Distribuição das teses e dissertações selcionadas por programa de pós-graduação ao longo dos anos (ano da defesa)

Tabela 12: Distribuição das teses e dissertações selecionadas por programa de pós-graduação

Tabela 13: Distribuição das teses e dissertações selecionadas por programa de pós-graduação, classificadas na categoria experiências/práticas e teórico/conceitual

Tabela 14: Distribuição das teses e dissertações selecionadas por programa de pós-graduação, classificadas na categoria que indica a região de abrangência das pesquisas

Tabela 15: Distribuição dos artigos selcionados por periódico ao longo dos anos (ano da publicação)

Tabela 16: Distribuição dos artigos selecionados por periódico, classificados na categoria de trabalho científico

Tabela 17: Distribuição dos artigos selecionados por periódico, classificados na categoria que indica a região de abrangência das pesquisas

Tabela 18: Artigos publicados em periódicos resultantes de pesquisas nos programas de pós-graduação pesquisados segundo ano de publicação

Tabela 19: Distribuição dos artigos por periódico e por tempo de intervalo entre produção e publicação 


\section{Lista de Gráficos}

Gráfico 1: Distribuição das teses e dissertações selecionadas por programa de pós-graduação

Gráfico 2: Distribuição dos artigos por periódico

Gráfico 3: Distribuição das teses, dissertações e artigos selecionados por categoria temática da Política de Atenção Básica, segundo ano de ocorrência

Gráfico 4: Distribuição dos artigos selecionados por categoria temática da Política de Atenção Básica, segundo ano de publicação

Gráfico 5: Distribuição das teses e dissertações selecionadas por categoria temática da Política de Atenção Básica, segundo ano de defesa

Gráfico 6: Distribuição das produções selecionadas da Política de Atenção Básica por tipo de produção segundo ano ocorrência

Gráfico 7: Distribuição dos artigos selecionados da Política de Atenção Básica segundo periódico

Gráfico 8: Distribuição das teses e dissertações selecionadas da Política de Atenção Básica segundo programa de pós-graduação

Gráfico 9: Distribuição das teses, dissertações e artigos selecionados por categoria temática da Política de Regionalização e Organizacão do SUS, segundo ano de ocorrência

Gráfico 10: Distribuição dos artigos selecionados por categoria temática da Política de Regionalização e Organização do SUS, segundo ano de publicação

Gráfico 11: Distribuição das teses e dissertações selecionadas por categoria temática da Política de Regionalização e Organização do SUS, segundo ano de defesa

Gráfico 12: Distribuição das produções selecionadas da Política de Regionalização e Organização do SUS por tipo de produção segundo ano ocorrência

Gráfico 13: Distribuição dos artigos selecionados da Política de Regionalização e Organização do SUS segundo periódico

Gráfico 14: Distribuição das teses, dissertações e artigos selecionados por categoria temática da Política de Educação na Saúde, segundo ano de ocorrência

Gráfico 15: Distribuição dos artigos selecionados por categoria temática da Política de Educação na Saúde, segundo ano de publicação

Gráfico 16: Distribuição das teses e dissertações selecionadas por categoria temática da Política de Educação na Saúde, segundo ano de defesa

Gráfico 17: Distribuição das produções selecionadas da Política de Educação na Saúde por tipo de produção segundo ano ocorrência

Gráfico 18: Distribuição dos artigos selecionados da Política de Educação na Saúde segundo periódico

Gráfico 19: Distribuição das teses e dissertações selecionadas da Política de Educação na Saúde segundo programa de pós-graduação 


\section{Lista de Linhas do Tempo}

Linha do Tempo 1: Documentos Oficiais da Política de Atenção Básica Linha do Tempo 2: Documentos Oficiais da Política de Atenção Básica Linha do Tempo 3: Documentos Oficiais da Política de Regionalização e Organização do SUS

Linha do Tempo 4: Documentos Oficiais da Política de Educação na Saúde Linha do Tempo 5: da Política de Atenção Básica do SUS

Linha do Tempo 6: da Política de Regionalização e Organização do SUS

Linha do Tempo 7: da Política de Educação na Saúde do SUS

Linha do Tempo 8: da Política de Atenção Básica do SUS (produção da SC e do SUS)

Linha do Tempo 9: da Política de Regionalização e Organização do SUS (produção da SC e do SUS)

Linha do Tempo 10: da Política de Educação na Saúde do SUS (produção da SC e do SUS)

Linha do Tempo 11: da Política de Atenção Básica do SUS (relação entre a produção da SC e do SUS)

Linha do Tempo 12: da Política de Regionalização e Organização do SUS (relação entre a produção da SC e do SUS)

Linha do Tempo 13: da Política de Educação na Saúde do SUS(relação entre a produção da SC e do SUS) 


\section{Lista de Siglas}

Abrasco - Associação Brasileira de Saúde Coletiva

AIH - Autorização de Internação Hospitalar

AIS - Ações Integradas de Saúde

AIS - Ações Integradas de Saúde

AMAQ - Autoavaliação para Melhoria do Acesso e da Qualidade de Atenção

Básica

AMQ - Avaliação para Melhoria da Qualidade da Estratégia Saúde da Família

APS - Atenção Primária à Saúde

ASSS - Administração de Sistemas e Serviços de Saúde

BIRD - Banco Internacional para Reconstrução e Desenvolvimento

BVS - Biblioteca Virtual da Saúde

CAPES - Coordenação de Aperfeiçoamento de Pessoal de Nível Superior

CAPs - Caixas de Aposentadoria e Pensões

CEBES - Centro Brasileiro de Estudos em Saúde

CEO - Centro de Especialidades Odontológicas

CEREST - Centro de Referência de Saúde do Trabalhador

CIB - Comissões Intergestores Bipartites

CIES - Comissão Permanente de Integração Ensino Serviço

CINAEM - Comissão Nacional de Ensino Médico

CIT - Comissão Intergestores Tripartite

CNRMS - Comissão Nacional de Residências Multiprofissionais em Saúde

CNS - Conselho Nacional de Saúde

COAP - Contrato Organizativo de Ação Pública

CONASEMS - Conselho Nacional de Secretários Municipais de Saúde

Conasp - Conselho Consultivo de Administração da Saúde Previdenciária

CONASS - Conselho Nacional de Secretários Estaduais de Saúde

COREDES - Conselhos Regionais de Desenvolvimento

CPMF - Contribuição Provisória sobre a Movimentação Financeira

DeCS - Descritores em Ciência da Saúde

DGSP - Diretoria Geral de Saúde Pública

EAD - Educação à Distância

ENSP/Fiocruz - Escola Nacional de Saúde Pública Sérgio Arouca/Fundação

Osvaldo Cruz

EPS - Educação Permanente em Saúde

ESF - Equipe de Saúde da Família

FIES - Fundo de Financiamento Estudantil

Finep - Financiadora de Estudos e Projetos

FMI - Fundo Monetário Internacional

FSP/USP - Fcauldade de Saúde Pública/Universidade de São Paulo

GERUS - Programa de Desenvolvimento Gerencial de Unidades Básicas de Saúde

HIV/AIDS - Vírus da Imunodeficiência Humana/ Síndrome da imunodeficiência

adquirida

IAPs - Institutos de Aposentadoria e Pensões

IDA - Integração Docente-Assistencial

IDH - Índice de Desenvolvimento Humano

IMS - Instituto de Medicina Social 
IMS/UERJ - Instituto de Medicina Social/Universidade do Estado do Rio de Janeiro

INAMPS - Instituto Nacional de Assistência Médica da Previdência Social

ISC/UFBA - Instituto de Saúde Coletiva/Universidade Federal da Bahia

LDB - Lei de Diretrizes e Bases da Educação Nacional

MEC - Ministério da Educação

MES - Ministério da Educação e da Saúde Pública

MPAS - Ministério da Previdência e Assistência Social

MPREV/UNICAMP - Medicina Preventiva/Universidade de Campinas

MPREV/USP - Medicina Preventiva/Universidade de São Paulo

MS - Ministério da Saúde

NASF - Núcleo de Apoio à Saúde da Família

NOAS - Norma Operacional de Assistência à Saúde

NOB - Norma Operacional Básica

OMS - Organização Mundial da Saúde

OP - Orçamento Participativo

OPAS - Organização Pan-americana para Saúde

PAB - Piso de Atenção Básica

PACS - Programa de Agentes Comunitários de Saúde

PAIS - Programa de Ações Integradas de Saúde

PDR - Plano Diretor de Regionalização

PDRH-OPAS - Programa de Desenvolvimento de Recursos Humanos

PET-SAÚDE - Programa de Educação pelo Trabalho para a Saúde

PGASS - Programação Geral de Ações e Serviços de Saúde

PIASS - Programa de Interiorização das Ações de Saúde e Saneamento

PIASS - Programa de Interiorização das Ações de Saúde e Saneamento

PISUS - Programa de Interiorização do Sistema Único de Saúde

PITS - Programa de Interiorização do Trabalho em Saúde

PMAQ - Programa de Melhoria, Acesso e Qualidade da Atenção Básica

PPI - Programação Pactuada e Integrada

PPSUS - Programa de Pesquisa para o SUS

PREPS - Programa de Preparação Estratégica de Pessoal da Saúde

Prev-Saúde - Programa Nacional de Serviços Básicos de Saúde

PRO-SAÚDE - Programa Nacional de Reorientação da Formação Profissional em

Saúde

PROESF - Programa de Expansão e Consolidação da Saúde da Família

PROFAE - Programa de Profissionalização dos Trabalhadores da Área de

Enfermagem

PROMED - Programa de Reorientação da Formação Médica

PROVAB - Programa de Valorização da Atenção Básica

PSE - Programa Saúde na Escola

PSF - Programa de Saúde da Família

RENASES - Relação Nacional de Ações e Serviços de Saúde

SAMHPS - Sistema de Atenção Médico-Hospitalar da Previdência Social

SAMU - Serviço de Atendimento Móvel de Urgência

SGTES - Secretaria de Gestão do Trabalho e da Educação na Saúde

SIA/SUS - Sistema de Informação Ambulatoriais do SUS

SIH/SUS - Sistema de Informações Hospitalares do SUS

SUDS - Sistema Unificado e Descentralizado de Saúde 
SUS - Sistema Único de Saúde UBS - Unidade Básica de Saúde

UCA - Unidade de Cobertura Ambulatorial

UERGS - Universidade Estadual do Rio Grande do Sul

UERJ - Universidade do Estado do Rio de Janeiro

UNASUS - Universidade Aberta do SUS

UNISC/RS - Universidade de Santa Cruz/Rio Grande do Sul

VER-SUS - Projeto de vivências e estágios na realidade do SUS 


\section{Apresentação}

Essa tese debate a Saúde Coletiva no Brasil analisando as mútuas influências entre o campo e as políticas públicas do Sistema Único de Saúde.

O desejo de estudar a Saúde Coletiva advém da implicação que a própria pesquisadora tem com o campo como formação e prática profissional.

Desde o ingresso na Universidade Estadual do Rio Grande do Sul (UERGS), no curso de graduação em Administração de Sistemas e Serviços de Saúde (ASSS), as interrogações sobre o campo eram inevitáveis. Na época, esse era o primeiro e o único curso de graduação em Saúde Coletiva no Brasil. Assim, desafiada como militante política e como profissional em busca de alternativas para atuação e inserção no mundo do trabalho, uma das maiores inquietações durante minha formação foi compreender melhor o campo da Saúde Coletiva.

A UERGS foi criada em 2001, a partir do Orçamento Participativo Estadual ${ }^{1}$ (OP) e visava a formação profissional qualificada às necessidades locorregionais como estratégia de fortalecimento da máquina estatal.

O curso de graduação em ASSS surgiu nessa lógica, visando à qualificação da gestão do Sistema Único de Saúde (SUS). 0 pleito por qualificação da gestão do SUS era reivindicado há mais de 10 anos pelo Controle Social gaúcho, com a expectativa de assim contribuir para a organização efetiva do SUS e para a atenção às demandas sociais de saúde. 0 curso também foi apontado como prioritário nos Fóruns dos Conselhos Regionais de Desenvolvimento ${ }^{2}$ (COREDES).

\footnotetext{
${ }^{1}$ Durante o governo estadual de Olívio Dutra, no Rio Grande do Sul, foi criado o Orçamento Participativo (OP) com o intuito de democratizar o processo decisório sobre o planejamento financeiro do Governo. "O OP é um processo auto-regulamentado, que abre à participação direta da população a elaboração da Proposta Orçamentária do Estado, o acompanhamento da sua execução, bem como a discussão de indicadores de carência e da situação econômica e financeira do Governo" (FERLA; JAEGER, 2002, p. 182).

2 Os COREDES foram criados no Estado do Rio Grande do Sul em 1994, como estratégia de fomentar o desenvolvimento regional. Consistem em uma estrutura de articulação em 22 Regiões do Estado, mobilizando prioritariamente gestores públicos, instituições de ensino e pesquisa, representantes dos setores econômicos mais expressivos em cada região e alguns setores do movimento social. Na prática, essas estruturas têm a prerrogativa de constituir diagnósticos de necessidades e eleger prioridades regionais para subsidiar o Governo na elaboração da proposta orçamentária. No período de vigência do Orçamento Participativo Estadual (OP), constituiu-se um conjunto de tensões entre essas estruturas e a dinâmica do OP, cuja participação era ascendente, com instâncias abertas e eleição de representantes para as etapas fechadas. Um protocolo de cooperação entre o Governo do Estado e a estrutura dos COREDES aproximou ambas as estratégias, cabendo aos Conselhos parte do protagonismo na mobilização do processo
} 
A graduação foi criada com o intuito de formar profissionais qualificados para a gestão do sistema de saúde em seus diversos âmbitos, havendo ênfase especial à transformação do modelo de atenção.

Atualmente já são 21 cursos enfrentando o desafio de formar não somente gestores, mas sanitaristas na graduação, uma vez que historicamente essa era uma titulação posgraduada. Está em plena efervescência o debate sobre os melhores caminhos a se trilhar nessa formação, considerando a complexidade do campo e a imperativa relevância social e política dessa graduação.

Em março de 2007, o mestrado em Saúde Coletiva, no Instituto de Medicina Social da Universidade do Estado do Rio de Janeiro, foi o espaço escolhido para refletir sobre os saberes e as práticas da Saúde Coletiva no Brasil, sua formulação e constituição nos arranjos organizacionais, acadêmicos, sociais e governamentais, explorando a singularidade do movimento aqui produzido.

Para o doutorado, a busca foi diferente. Após quase 4 anos de trabalho na Secretaria de Saúde do Estado da Bahia, experimentando e vivenciando o SUS cotidianamente, pude perceber as dificuldades na operação e gestão do sistema, e a pergunta que me instigava era como pensar em novas alternativas e inovações para o sistema? A Saúde Coletiva estaria trabalhando nesse sentido? 0 conhecimento eventualmente produzido estaria chegando aos gestores e trabalhadores?

Assim, nasceu o tema da pesquisa. Analisar as mútuas influências entre Campo da Saúde Coletiva e SUS. Estão em sintonia? Potencializam-se?

A tese apresenta alguns achados que instigam a problematização de importantes questões no campo da Saúde Coletiva, interrogando sua lógica produtiva, bem como no SUS, do ponto de vista de sua relação com a academia e da produção de políticas. A proposta do ciclo de análise de políticas de Ball foi a base conceitual desta produção.

0 que nos interessa colocar em debate com gestores e pesquisadores é a "sensação genérica" de desencontro entre as necessidades do SUS e as pesquisas. Trabalhar com gestores quais seriam suas perguntas, perspectivas, problemas, e confrontá-las com a produção acadêmica recolhida a partir das teses, 
dissertações e artigos, é objetivo desse estudo. Assim, ser dispositivo para abrir o debate e repensar as produções de ambos os planos e como podem se potencializar caso se reconheçam nessa perspectiva de apoio e colaboração.

Um primeiro olhar feito foi em relação a produção temática tanto das políticas como das produções do campo da Saúde Coletiva. A leitura atenta ao conjunto dos documentos das políticas bem como dos textos que foram produzidos a partir da suas produções, possibilitou um mapeamento dos conceitos e das idéias centrais que circularam ao longo do tempo. Ainda, a análise temática das produções do campo, teses, dissertações e artigos publicados em periódicos, possibilitou identificar os movimentos dos conceitos que foram sendo utilizados e produzidos ao longo dos anos. Ao buscar analisar esses movimentos conceituais, ao longo do tempo, tendo uma visão ampla de ambos os planos de produção, podemos perceber que, em geral, não há uma relação direta de influência entre a produção das políticas e a produção de conhecimentos, e viceversa. 0 que fica envidente é uma relação entre os planos com o motivo de consumo aplicação dos conceitos produzidos, no entanto, não percebemos uma influência de uma plano no outro que produza deslocamento no movimento de produção de cada um. 


\section{A Saúde Coletiva no Brasil: o cenário e os pressupostos do estudo}

Parto do pressuposto de que a Saúde Coletiva no Brasil se conformou enquanto campo científico a partir dos anos 80, considerando, entretanto, a própria definição de campo científico por vezes insuficiente para caracterizar o movimento político-ideológico-intelectual que configura a Saúde Coletiva no Brasil.

A compreensão do campo da Saúde Coletiva estaria não necessariamente nas propriedades que ele apresenta, e sim no conjunto das relações que o permeiam. Segundo Bourdieu (2005), a realidade social das instituições se define e redefine continuamente na disputa de interesses dos agentes que dela fazem parte, conforme suas posições e habitus, conformando o campo de forças antagonistas ou complementares que explicam a razão de ser das instituições e seus efeitos. Portanto, ao compreender que os campos se conformam apoiados na disputa de Verdades e que essas são produzidas por indivíduos ou coletivos, pode-se compreender que os mesmos, revestidos de poder, estão em interação para a legitimação dos saberes.

A constituição deste campo de saberes e práticas foi marcada pela ousadia na junção e intercessão entre as áreas específicas objetivando produzir um novo que reunisse a riqueza das partes e das especificidades. Reconhecendo a importância da diversidade destes saberes e práticas, mas propondo um modo inovador de pensar e fazer saúde, inicialmente foi priorizada a interlocução e relação entre os diferentes. Talvez seja interessante dizer que não se trata de superposição, mas de agregação e composição, tensionando para que os limites destas divisões sejam fluidos, para que se estabeleçam intercessões que remodelem estas divisões historicamente estabelecidas em resposta às necessidades em saúde. (Morin, 2005)

A Saúde Coletiva não se coloca enquanto campo para disputar uma única Verdade sobre a saúde e sua produção, pois é um campo multi, inter, transdisciplinar, marcado por diferentes correntes teóricas, que traz a riqueza da articulação de diversas Verdades para a produção de novos saberes e novas práticas. O campo da saúde coletiva se produz nos encontros: entre as disciplinas, as teorias, os conceitos, para nesse mesmo espaço serem produzidos saberes e práticas, produto de diversas interações e conjunções, para produzir 
novidade para além das fronteiras rígidas das ciências, para conversar com a vida e ter sentido social, considerando que a realidade da saúde é complexa e multifatorial. Trata-se de um campo singular, único. (CECCIM, 2004; MERHY, 2007)

A partir dessa compreensão, é importante lembrar que a trajetória da Saúde Coletiva no Brasil sofreu interferências e influências do processo e movimento da Reforma Sanitária e da criação do SUS. Contudo, não se esgotam aí os vetores da sua produção. A história da Reforma Sanitária não é a história da Saúde Coletiva no Brasil: ela é parte contida e intercessora dessa trajetória; às vezes se confundem em determinados episódios marcantes, mas se diferenciam em outros. As duas não são a mesma e devem ser entendidas nas suas singularidades históricas e político-conceituais.

Sônia Fleury, durante a entrevista para o mestrado da autora, já destacava que: "A gente trabalhava mais ou menos os mesmos eixos, da determinação, das práticas, e tudo isso, mas eu acho que tudo isso deu uma identidade política e não só científica, não era só um campo científico, era um campo de atuação política, tinha a visão política de compreensão da saúde do ponto de vista político. (diferente dos outros campos de conhecimento) Havia um esforço muito grande dos epidemiólogos para parecer que eram cientistas mas eu acho que não é bem o caso da saúde coletiva, ela tinha outros objetivos, queria também saber como interpretar o mundo, mas acho que a interpretação era muito política, muito no sentido de transformá-lo." Essa particularidade nos encontros entre a Saúde Coletiva enquanto campo e o movimento da Reforma Sanitária foi objeto de análise desse estudo.

Contudo, qual é mesmo essa relação estabelecida entre a Saúde Coletiva e o SUS? Para o campo da Saúde Coletiva, a criação do SUS representou um conjunto de conquistas do movimento da Reforma Sanitária e, ao mesmo tempo, um marco para um processo de estatização das lutas sociais postas em ação na década de 70 e 80. Se na academia as lutas sociais foram levadas ao espaço de elaboração de conhecimento a partir das ciências oficiais, no Estado, elas perderam forças para as disputas pelo estabelecimento de espaços formais e oficiais para sua ação. A construção do SUS fortaleceu o projeto social de um novo modelo de atenção e gestão para a saúde no Brasil, mas para o movimento que buscava 
estar em constante reflexão sobre si mesmo esse novo cenário deixou claro o enfraquecimento de algumas forças, especialmente pelo modus operandi da produção da política e da ciência.

Entrelaça-se aqui, a questão da política na e da Saúde Coletiva. Em outros termos, na medida em que existe uma articulação estreita entre a produção do conhecimento, concebida enquanto uma prática política, e a estratégia política real do movimento sanitário brasileiro, esta acabou por imprimir a marca àquela, que se configura, então, como um saber militante (COHN, 1992, p. 99-100).

A mesma autora destaca que a prática política da Reforma Sanitária Brasileira se constituiu como horizonte e ao mesmo tempo como limite para a produção de conhecimento no campo. Isso aconteceu, pois o campo, num âmbito, buscava se institucionalizar como um novo modelo político para saúde no país, e noutro âmbito, buscava construir um projeto potente para produção de novos conhecimentos. No entanto, a produção de conhecimento do campo, apesar de influenciada pelo movimento sanitário que disputou uma nova forma de produção, teve forte influência das ciências oficiais o que a limitou. Tanto o SUS como a Saúde Coletiva estiveram influenciados pelas disputas postas no cenário e ambos foram por elas limitados.

Assim, é importante ressaltar que, desde o início da conformação do campo da Saúde Coletiva no Brasil, os coletivos sempre influenciaram a conformação das produções científico-conceituais e a formulação e implementação das políticas. Foram os grupos e os movimentos desses grupos que mobilizaram as produções, que significaram as disputas e que validaram as Verdades. É sobre essas relações, esses encontros entre os atores e as produções que eles protagonizaram que o presente estudo pretende focar, com o intuito de explorar que articulações e interseções do campo e do sistema de saúde ocorreram no Brasil.

Pretendeu-se identificar as relações, as influências na conformação dos campos, os poderes que atravessaram o contexto de determinadas produções, sejam políticas ou conhecimentos. A partir de que problemas as agendas políticas são produzidas? O SUS ou a Saúde Coletiva protagonizam esse movimento? Como esse movimento se estabelece? Quais interesses estão envolvidos? Que vetores atravessam os campos? Que relações se estabelecem? Como e quais são os encontros e desencontros que acontecem? 
Assim, a partir dessas e de outras perguntas, compreendendo o cenário do estudo, pretendeu-se explorar as bases da construção deste projeto.

\section{O tema estudado:}

As relações (articulações e interseções) que se estabelecem entre o campo da Saúde Coletiva e o Sistema Único de Saúde

\section{Pergunta-chave:}

Como o campo da Saúde Coletiva e o Sistema Único de Saúde se influenciam mutuamente na construção (conceitual e política) de suas agendas no Brasil?

\section{Objetivos}

\section{Objetivo Geral:}

Analisar as interações entre o campo da Saúde Coletiva e o Sistema Único de Saúde (SUS) na construção de suas agendas.

\section{Objetivos Específicos:}

1. Identificar o movimento de produção das políticas de saúde (como circulam conceitos e atores - disputas, processos, cenários); e

2. Identificar o movimento de produção do campo da Saúde Coletiva (especialmente no campo da gestão e das políticas). 
Os vôos por várias direções e os planos analíticos da pesquisa: os

\section{passos desenvolvidos para viabilizar o estudo}

A proposta desse estudo se deu a partir de um protagonismo da pesquisadora em sua relação afetiva com a temática. As reflexões que foram desenvolvidas neste estudo buscam trazer novos elementos para entender o campo da Saúde Coletiva e sua relação com o SUS.

É importante registrar que neste estudo reconheço que:

Na investigação social (...) a visão de mundo do pesquisador e dos atores sociais estão implicadas em todo o processo de conhecimento, desde a concepção do objeto até o resultado do trabalho. É uma condição da pesquisa, que uma vez conhecida e assumida pode ter como fruto a tentativa de objetivação do conhecimento. Isto é, usando-se todo o instrumental teórico e metodológico quue ajuda uma aproximação mais cabal da realidade, mantém-se a crítica não só sobre as condições de compreensão do objeto como do próprio pesquisador. Conforme nos adverte Lévy Strauss:" Numa ciência onde o observador é da mesma natureza que o objeto, o observador é, ele mesmo, uma parte de sua observação" (Strauss, 1975 apud Minayo, 2004, p.21).

Para análise dos encontros e desencontros, das mútuas influências entre o campo da Saúde Coletiva e o SUS, foi feito um recorte para o campo temático da política e da gestão - o que intensifica a implicação da autora, já que exatamente esse tem sido seu campo de atuação profissional.

O objeto, o foco do estudo e as estratégias e investigação refletem a capacidade do analista de se reconhecer e de enunciar as questões que o mobilizam. (...) se já há interesse por analisar política é porque jea ocorreu a entrada do analista no jogo e, por isso, não há como não se implicar e não se reconhecer nele; mas para se reconhecer também é preciso romper, sair do espaço da obviedade e do sentido normativo da política, sair do domínio daqueles que entendem de política para assumir a postura de quem não entende, mas que pode falar e refletir sobre ela; assumir que não se quer render-se ao domínio daqueles que pretensamente sobem o que é política (Mattos e Baptista, 2011b, p. 66).

Ao investigarmos as produções do campo da saúde coletiva, buscamos explorar que colaborações o campo trouxe para a construção dos saberes e conhecimentos difundidos por ele e em que esse campo influenciou na implementação e organização do sistema.

Para pensar políticas de saúde, tomou-se como um conceito relevante o de biopolítica trazido por Foucault, que situa a medicina e as ações de saúde 
(individuais e coletivas) como estratégias de biopoder construídas socialmente. O reconhecimento da biopolítica como estratégia da governamentalidade neoliberal nos exige um olhar crítico sobre a construção das políticas de saúde no Brasil e pode nos ajudar na análise dessas políticas em relação às formulações do campo da Saúde Coletiva. Mais adiante vamos explorar o conjunto de conceitos que foram essenciais para o olhar desenvolvido pelo estudo.

Além desse, outros vetores também compões movimentos de atravessamento a ambos os planos, são eles: Agenda internacional da Saúde (OPAS, Banco Mundial, etc), Agenda da Reforma Sanitária, Interesses econômicos, o complexo médicoindustrial, e etc.

Foram os seguintes os procedimentos adotados para a realização da pesquisa:

a) análise sistemática de banco de teses e dissertações (ENSP/Fiocruz, IMS/UERJ, MPREV/UNICAMP, FSP/USP, MPREV/USP, ISC/UFBA) e de periódicos (Ciência e Saúde Coletiva, Cadernos de Saúde Pública e Revista de Saúde Pública) relevantes para o campo da saúde coletiva;

b) construção da matriz inicial de análise documental (principais documentos oficiais das políticas selecionadas para análise);

c) construção das categorias de análise considerando um conjunto de elementos investigados;

d) análise de textos produzidos sobre a construção e implementação das políticas pesquisados;

e) produção de uma síntese analítica sobre as mútuas influências observadas através do movimento de produção de textos sobre as políticas de saúde tanto nos textos oficiais como nos textos de quem escreveu sobre elas.

Os dois últimos passos foram produzidos a partir de leituras e análises sobre os documentos institucionais e oficiais das políticas, descritos mais adiante detalhadamente, e sobre textos de autores que escreveram sobre a construção e implementação da política.

Sobre a matriz de análise construída, é importante registrar que foram organizadas as informações da seguinte forma: 
Os Bancos de Teses e Dissertações selecionadas foram organizados a partir de uma leitura atenciosa feita nos bancos intencionalmente selecionados, disponíveis na internet. A seleção levou em consideração os achados da pesquisa de mestrado da autora que apontou esses 5 programas como altamente relevantes ao campo da Saúde Coletiva desde o processo de constituição do SUS. É importante registrar que muitos bancos das universidades ainda não estão totalmente digitalizados e por isso há um recorte temporal heterogêneo entre as instituições/programas. Somente foram selecionadas produções já disponíveis nos sítios eletrônicos durante a pesquisa.

Durante esse processo de busca, houve idas e vindas na definição das categorias, à medida que se ampliava o olhar sobre o material.

A seleção das teses, dissertações e artigos foi feita a partir da leitura do título, das palavras-chave e do resumo das teses e dissertações, havendo leitura de parte da produção completa somente quando havia dúvida sobre o tema e seu desenvolvimento.

Para a organização do banco de teses e dissertações, foram coletadas as seguintes informações: ano da defesa; tipo de produção (tese, dissertação e dissertação profissional); autor; orientador (e co-orientador quando havia); título; palavras-chave; resumo; link onde está disponível. 0 banco foi organizado em excel com planilhas separadas por programas de pós-graduação.

Foram encontradas 300 teses, dissertações e dissertações profissionais no ISC/UFBA desde 2000; 1308 na ENSP/Fiocruz desde 2005; 517 no IMS/UERJ desde 1989; 952 na FSP/USP desde 1999; 191 na MPREV/USP desde 1995; e 250 na MPREV/UNICAMP desde 1991. Após leitura atenta, foram selecionadas 432 producões. Destas, 280 são dissertações de mestrado, 19 dissertações de mestrado profissional, 131 teses e 2 teses de livre-docência. 
Tabela 1: Distribuição dos trabalhos segundo data de início do banco on line, número total de trabalhos e número de trabalhos selecionados

\begin{tabular}{lccc} 
Bancos pesquisados & Ano - on line & Quantidade total & $\begin{array}{l}\text { Quantidade } \\
\text { selecionada }\end{array}$ \\
\hline ISC/UFBA & 2000 & 300 & 34 \\
ENSP/Fiocruz & 2005 & 1308 & 169 \\
IMS/UERJ & 1989 & 517 & 67 \\
FSP/USP & 1999 & 952 & 41 \\
MPREV/USP & 1995 & 191 & 36 \\
MPREV/UNICAMP & 1991 & 250 & 85
\end{tabular}

Há uma diversidade de produção de acordo com cada Programa analisado, o que será explorado adiante.

Tabela 2: Distribuição dos trabalhos selecionados segundo programa e grau acadêmico

\begin{tabular}{lccccc} 
Programas & Dissertação & $\begin{array}{c}\text { Dissertação - } \\
\text { Profissional }\end{array}$ & Tese & $\begin{array}{c}\text { Tese } \\
\text { LD }\end{array}$ & Total \\
\hline ENSP/Fiocruz & 133 & & 36 & & 169 \\
FSP/USP & 26 & & 13 & 2 & 41 \\
IMS/UERJ & 39 & 2 & 26 & & 67 \\
ISC/UFBA & 13 & 17 & 4 & 34 \\
MPREV/UNICAM & 46 & & 39 & 85 \\
P & 23 & & 13 & & 36 \\
MPREV/USP & & & &
\end{tabular}

Como se pode ver na tabela abaixo, há uma concentração da produção. Em parte isso se justifica pelo fato de que muitos bancos de teses e dissertações ainda não estão totalmente disponíveis em formato digital bem como pelo período de criação dos programas.

A FSP/USP tem o Programa mais antigo, com início em 1970, juntamente com o Programa de Medicina Preventiva da USP. O Programa da UNICAMP teve seu início em 1965, mas somente em 1970 foram introduzidas questões da Medicina Social. O Programa do IMS/UERJ teve início em 1973. O Programa da ENSP/Fiocruz foi iniciado em 1977. Na UFBA foi criado em 1973 um Mestrado 
em Saúde Comunitária na Faculdade de Medicina, mas somente em 1995 foram criados o ISC e o Programa de Pós-Graduação em Saúde Pública.

Tabela 3: Distribuição dos trabalhos selecionados por ano de produção e grau acadêmico

\begin{tabular}{|c|c|c|c|c|c|}
\hline Ano & Dissertação & $\begin{array}{c}\text { Dissertação - } \\
\text { Profissional }\end{array}$ & Tese & Tese LD & Total \\
\hline 1991 & & & 1 & & 1 \\
\hline 1995 & 2 & & 1 & & 3 \\
\hline 1997 & 3 & & 1 & & 4 \\
\hline 1998 & 3 & & & & 3 \\
\hline 1999 & 5 & & & & 5 \\
\hline 2000 & 3 & & 3 & & 6 \\
\hline 2001 & 9 & & 4 & & 13 \\
\hline 2002 & 2 & & 2 & & 4 \\
\hline 2003 & 1 & & 2 & & 3 \\
\hline 2004 & 9 & & 2 & 1 & 12 \\
\hline 2005 & 4 & 1 & 10 & & 15 \\
\hline 2006 & 10 & & 13 & & 23 \\
\hline 2007 & 10 & & 16 & 1 & 27 \\
\hline 2008 & 23 & 1 & 8 & & 32 \\
\hline 2009 & 55 & 1 & 12 & & 68 \\
\hline 2010 & 31 & 8 & 15 & & 54 \\
\hline 2011 & 35 & 2 & 14 & & 51 \\
\hline 2012 & 37 & 2 & 11 & & 50 \\
\hline 2013 & 34 & 4 & 10 & & 48 \\
\hline 2014 & 4 & & 6 & & 10 \\
\hline Total & 280 & 19 & 131 & 2 & 432 \\
\hline
\end{tabular}

Para exploração do banco de dissertações e teses, foram criadas categorias temáticas e de tipologia da produção, são elas:

Planos Analíticos: Qual?

- Teórico-conceitual

- Experiências/práticas

Experiência/Locus: Qual?

- Serviço/local

- Município Pequeno

- Município Médio

- Município Grande 
- Região

- País

- ND

A sigla ND foi criada para as produções onde não foi possível identificar um locus específico.

Tipo de Análise: Qual?

- Analítico Descritivo

- Analítico Propositivo

Buscou-se identificar se se o estudo produziu uma análise mais descritiva do objeto estudado, ou se conseguiu, a partir das reflexões, formular propostas concretas para atuação em relação ao problema do estudo.

Contextualização do cenário/atores/etc:

- Contextualizado

- Não definido

A categoria relacionada ao contexto investigou se as produções apresentavam a contextualização do cenário estudado.

Em cena: apresenta atores, arenas, etc?

- Coloca atores em cena/jogos de poder/ disputas de projeto

- Não apresenta

Metodologia utilizada:

- Quantitativa

- Qualitativa

- Quanti-qualitativa

Fontes dos Dados:

- Dados Primários

- Dados Primários e Secundários

- Dados Secundários 
Foram criadas as categorias temáticas para potencializar a análise sobre as produções . Dentro de cada uma das categorias temáticas, que destacam grandes elementos de cada uma das políticas aqui analisadas (Política de Atenção Básica; Política de Educação na Saúde; Regionalização e organização do SUS) foram criadas outras sub-categorias e no processo de categorização foram apontadas duas para cada produção, a temática principal e secundária.

A ideia foi proporcionar uma visibilidade ampliada sobre o conjunto de temáticas abordadas nas pesquisas em foco.

São as seguintes as categorias utilizadas:

Tabela 4: Lista das categorias e sub-categorias temáticas utilizadas para a categorização dos dados das produções do campo da Saúde Coletiva selecionadas

\begin{tabular}{|c|c|}
\hline & Atenção Básica \\
\hline 1.1 & Doenças e agravos prioritários (hipertensão, diabetes, tuberculose, etc) \\
\hline 1.1 .1 & AIDS/HIV e outras doenças sexualmente transmissíveis \\
\hline 1.1 .2 & outras coisas \\
\hline 1.1.3 & política \\
\hline 1.1.4 & processo de trabalho \\
\hline 1.1.5 & resultado de ações de saúde \\
\hline 1.1 .6 & usuário (ponto de vista) \\
\hline 1.1.7 & vigilância em saúde \\
\hline 1.1 .8 & violência \\
\hline 1.2 & Trabalho \\
\hline 1.2.1 & acolhimento \\
\hline 1.2.10 & ACS \\
\hline 1.2.2 & ambiente/condições de trabalho \\
\hline 1.2 .3 & apoio/matriciamento \\
\hline 1.2 .4 & atuação de categorias profissionais \\
\hline 1.2 .5 & equipe de saúde \\
\hline 1.2.6 & micropolítica \\
\hline 1.2 .7 & NASF \\
\hline 1.2 .8 & outras ferramentas de gestão do trabalho \\
\hline 1.2 .9 & processo de trabalho \\
\hline 1.3 & Perspectiva do Usuário \\
\hline 1.3.1 & adesão a ações e programas \\
\hline 1.3 .2 & ponto de vista/avaliação \\
\hline 1.4 & $\mathrm{AB}$ e redes de cuidado \\
\hline 1.4 .1 & acesso as ações e serviços de saúde \\
\hline 1.4.10 & ações programáticas (bucal, nutrição, assist. Farmac., etc) \\
\hline 1.4.11 & Articulação dos serviços - rede \\
\hline 1.4 .12 & biopolítica \\
\hline 1.4 .13 & ciclos de vida \\
\hline 1.4.14 & Dispositivos de gestão do cuidado \\
\hline 1.4 .2 & diversificação de ofertas de cuidado (saúde mental, práticas integrativas, etc) \\
\hline 1.4 .3 & encaminhamento/referência \\
\hline 1.4.4 & grupos e educação em saúde \\
\hline 1.4 .5 & Integralidade \\
\hline
\end{tabular}




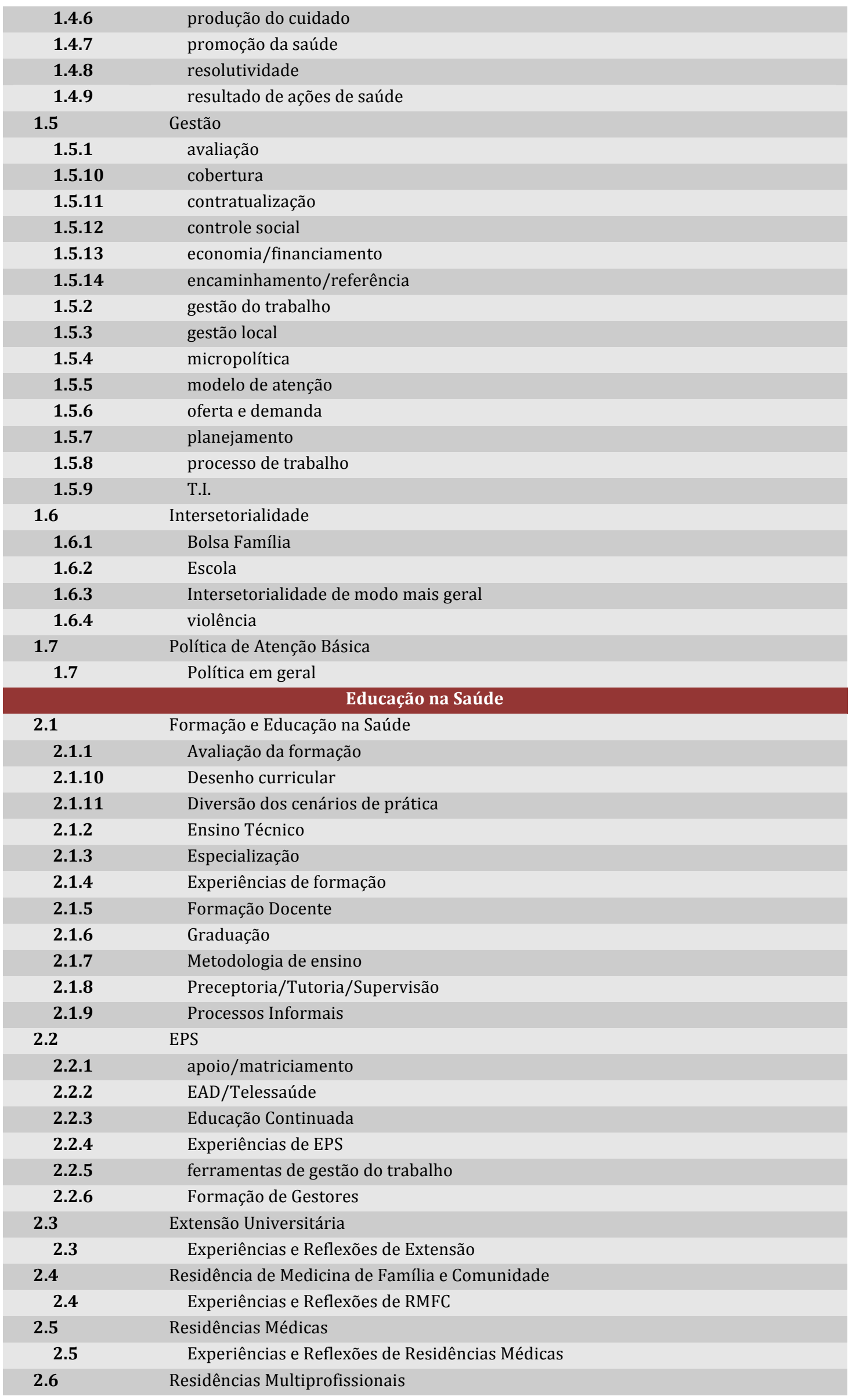




\begin{tabular}{|c|c|}
\hline 2.6 & Experiências e Reflexões de RMS \\
\hline 2.7 & VER-SUS \\
\hline 2.7 & Experiências e Reflexões de VER-SUS \\
\hline 2.8 & Política de EPS \\
\hline 2.8 .1 & Análise da política \\
\hline 2.8.10 & Aprender-SUS \\
\hline 2.8 .2 & Avaliação da política \\
\hline 2.8.3 & Escolas de Saúde Pública e de ETSUS \\
\hline 2.8.4 & estratégia de gestão \\
\hline 2.8 .5 & Pet-Saúde \\
\hline 2.8 .6 & Política de EPS (Pólos de EPS e Pólos de SF) \\
\hline 2.8 .7 & Pólos e outros espaços colegiados (CIES, etc) \\
\hline 2.8.8 & Pró-Saúde \\
\hline \multirow[t]{2}{*}{2.8 .9} & Promed \\
\hline & Regionalização e Organização do SUS \\
\hline 3.1 & Regionalização \\
\hline 3.1 & Sobre Regionalização \\
\hline 3.2 & Descentralização \\
\hline 3.2 & Sobre Descentralização \\
\hline 3.3 & Municipalização \\
\hline 3.3 & Sobre Municipalização \\
\hline 3.4 & Colegiados Regionais \\
\hline 3.4 & Sobre Colegiados Regionais \\
\hline 3.5 & Relação Interfederativa \\
\hline 3.5 .1 & articulação intergestores \\
\hline 3.5 .2 & Disputas/conflitos políticos \\
\hline 3.5.3 & espaços colegiados (CIB, CIT, colegiados, etc) \\
\hline 3.6 & Redes Regionalizadas \\
\hline 3.6 & Sobre Redes Regionalizadas \\
\hline 3.7 & Financiamento \\
\hline 3.7 & Sobre Financiamento \\
\hline 3.8 & Planejamento \\
\hline 3.8 & Sobre Planejamento \\
\hline 3.9 & Instrumentos da política \\
\hline 3.9 .1 & avaliação em saúde \\
\hline 3.9 .2 & consórcios \\
\hline 3.9 .3 & decreto \\
\hline 3.9 .4 & normas operacionais \\
\hline 3.9 .5 & pacto \\
\hline 3.10 & Relação Público-Privada \\
\hline 3.10 .1 & Contratos \\
\hline 3.10 .2 & contratualização \\
\hline 3.10 .3 & Relações políticas \\
\hline 3.11 & Aspectos políticos e operativos do sistema de saúde (modelos de gestão e atenção) \\
\hline 3.11 & Aspectos políticos e operativos do sistema de saúde (modelos de gestão e atenção) \\
\hline 3.12 & Modelagens de gestão (apoio, estratégias inovadoras, etc) \\
\hline 3.12 & Modelagens de gestão (apoio, estratégias inovadoras, etc) \\
\hline 3.13 & Acesso e Integralidade (produção do cuidado) \\
\hline 3.13 & Acesso e Integralidade (produção do cuidado) \\
\hline
\end{tabular}

Para a coleta e análise dos artigos publicados nos periódicos foi utilizada a mesma sistemática, com pequenas modificações. A seleção foi feita partir da 
leitura do título, palavras-chave e resumo, sendo que foi lida parte da produção completa somente quando havia dúvida sobre o tema e seu desenvolvimento. Vale ressaltar que em função do tamanho limitado dos resumos e da adoção de títulos pouco descritivos, a leitura parcial dos artigos foi necessária para 30 a $40 \%$ dos artigos.

Para a organização do banco foram coletadas as seguintes informações: ano da publicação; tipo de produção (pesquisa, revisão bibliográfica, análise documental, opinião, experiência); autor(es); título; palavras-chave; resumo; link em que está disponível.

Outra informação coletada foi o ano de realização da pesquisa, quando disponível, e a língua de publicação para quando o português não era a língua principal. As mesmas categorias utilizadas para as Teses e Dissertações foram aplicadas aqui.

A escolha dos periódicos foi feita considerando a avaliação CAPES de periódicos e outras experiências encontradas na literatura, particularmente dois artigos que apontam os 3 periódicos com maior número proporcional de publicações da Saúde Coletiva/Saúde Pública e alguns dos fatores de impacto mais altos do campo. São eles: Cadernos de Saúde Pública, Ciência \& Saúde Coletiva e Revista de Saúde Pública. (Viacava, 2010; e Barros, 2006)

No total da busca e da seleção de artigos dos 3 periódicos, foram selecionados 684 artigos.

Tabela 5: Distribuição dos artigos segundo data de início do banco on line e número de artigos selecionados

\begin{tabular}{|lcc|}
\hline Periódicos pesquisados & $\begin{array}{c}\text { Ano - on } \\
\text { line }\end{array}$ & $\begin{array}{c}\text { Quantidade } \\
\text { selecionada }\end{array}$ \\
\hline Cadernos de Saúde Pública & 1989 & 228 \\
Ciência e Saúde Coletiva & 1998 & 376 \\
Revista de Saúde Pública da USP & 1989 & 80
\end{tabular}

Foram usados os seguintes critérios de exclusão: artigos em outra língua que não tivessem pelo menos o resumo em português (entre os artigos selecionados, 8 foram escritos na língua inglesa, todos na Revista Cadernos de Saúde Pública); artigos de opiniões dos debates (os debates de temas afins com o estudo foram selecionados, mas as opiniões, replicas, etc não foram selecionadas); resenhas de 
livros e outras publicações; editoriais das revistas; e artigos de publicações institucionais específicas. 
Tabela 6: Distribuição dos artigos selecionados segundo periódico e tipo de produção

\begin{tabular}{lccccc} 
Periódicos & Teórico & Experiência & Opinião & Pesquisa & $\begin{array}{c}\text { Revisão } \\
\text { Bibliográfica }\end{array}$ \\
\hline $\begin{array}{l}\text { Cadernos de } \\
\text { Saúde Pública }\end{array}$ & 23 & 9 & 8 & 186 & 2 \\
$\begin{array}{l}\text { Ciência e } \\
\begin{array}{l}\text { Saúde Coletiva } \\
\text { Revista de }\end{array}\end{array}$ & 48 & 17 & 15 & 274 & 22 \\
$\begin{array}{l}\text { Saúde Pública } \\
\text { da USP }\end{array}$ & 2 & 6 & 1 & 68 & 3 \\
\hline
\end{tabular}

Se observados os artigos, por sua tipologia, ao longo dos anos, veremos a seguinte distribuição. É interessante registrar que essas tipologias foram elaboradas a partir da observação dos artigos. Apesar de destacarmos uma como pesquisa, não necessariamente quer dizer que as demais produções não sejam produtos de um trabalho de pesquisa, mas, o destque feito é referente a pesquisas que envolvem trabalho de campo, onde fica evidente um processo de coleta de dados que não seja somente a pesquisa bibliográfica e/ou documental. 0 dado interessante nessa categorização de tipo de artigos, ao encontrar a seleção realizada, é a predominância de artigos produzidos a partir de pesquisas, o que evidencia o movimento que o campo da Saúde Coletiva está fazendo na produção de pesquisas, seja no âmbito dos próprios programas de pósgraduação, seja nos diferentes grupos e projetos de pesquisa que são financiados de diferentes formas. Ou seja, existe um movimento relevante de produção de pesquisas no campo e o estudo buscou conhecer melhor qual o objeto, metodologia, etc, e a que questões e problemas estão se direcionando. 
Tabela 7: Distribuição dos artigos selecionados por ano e tipo de produção

\begin{tabular}{|c|c|c|c|c|c|}
\hline Ano & Teórico & Experiência & Opinião & Pesquisa & Revisão Bibliográfica \\
\hline 1989 & & 3 & 1 & 1 & \\
\hline 1990 & & 1 & 1 & & \\
\hline 1991 & & & & 2 & \\
\hline 1992 & 1 & 2 & 1 & 3 & \\
\hline 1993 & & & 2 & 1 & \\
\hline 1995 & & & & 2 & \\
\hline 1996 & & 1 & & & \\
\hline 1997 & 2 & & & 1 & \\
\hline 1998 & & 1 & & 3 & \\
\hline 1999 & 5 & 2 & & 4 & \\
\hline 2000 & 4 & 1 & & 2 & \\
\hline 2001 & 2 & 2 & 1 & 9 & \\
\hline 2002 & 4 & 1 & 3 & 10 & 2 \\
\hline 2003 & 5 & 2 & 4 & 3 & \\
\hline 2004 & 1 & 1 & 2 & 12 & 1 \\
\hline 2005 & 3 & 2 & 1 & 19 & \\
\hline 2006 & 2 & & 2 & 23 & 2 \\
\hline 2007 & 11 & & 1 & 23 & 1 \\
\hline 2008 & 2 & 3 & 1 & 60 & 3 \\
\hline 2009 & 10 & 2 & 2 & 56 & 1 \\
\hline 2010 & 5 & 2 & & 62 & 4 \\
\hline 2011 & 10 & & 1 & 75 & 2 \\
\hline 2012 & 2 & 4 & & 65 & 2 \\
\hline 2013 & 2 & & 1 & 41 & 4 \\
\hline 2014 & 2 & 2 & & 51 & 5 \\
\hline Total & 73 & 32 & 24 & 528 & 27 \\
\hline
\end{tabular}

Para exploração do banco de artigos de periódicos, foram utilizadas as categorias temáticas e de tipologia da produção já apresentadas. Assim, foi possível analisar ambos os bancos juntos e separados, demonstrando os diferentes movimentos entre o que está sendo produzido no campo e o que está sendo publicado nos periódicos de maior relevância para o campo.

Além desse trabalho com os bancos de dados, foi desenvolvido um estudo teórico e conceitual, documental para qualificar as reflexões e análises sobre as políticas. Na tentativa de identificar conceitos-chave e as principais disputas na produção das políticas ao longo do tempo, terminei construindo uma certa história das políticas selecionadas. 
O projeto de doutorado respeitou os princípios éticos previstos na Resolução CNS 196/00. 0 projeto foi submetido ao Comitê de Ética e Pesquisa da Faculdade de Saúde Pública da USP e aprovado pelo parecer 193.050, emitido em 01 de fevereiro de 2013. O projeto foi submetido ao Comitê de Ética porque havíamos planejado uma escuta de atores que não foi possível realizar para a tese, mas que será efetivada depois da defesa. 
Contextualização e resgate de fatos relevantes do desenvolvimento da Saúde Pública e da Saúde Coletiva no Brasil

Não é uma tarefa fácil definir a Saúde Pública e a Saúde Coletiva tomando como ponto de referência o contexto brasileiro. A Saúde Pública - não somente no Brasil, mas internacionalmente - se desenvolveu por meio das políticas e ações de saúde dirigidas aos coletivos e as populações. Então, pode-se compreender a Saúde Pública enquanto política (social) governamental, articulada às relações entre Estado e o conjunto das classes sociais em um dado período histórico (MERHY, 1992, p.22).

Mas como foi produzido esse processo? Que fatos conformaram essa Saúde Pública? Ela pode ser melhor explicada com que conceitos? Que atores a conformaram? E a Saúde Coletiva? Como se configurou? Como pode ser compreendida? Para entendermos um pouco sobre essa história, vamos resgatar alguns fatos que podem ser considerados importantes marcadores. Esse resgate ajuda a embasar as reflexões que serão apresentadas posteriormente, pois é o campo da Saúde Coletiva que foi mais explorado aqui.

\section{Medicina: alguns fatos marcantes dessa história}

Desde a transição do feudalismo para o capitalismo, as ações de saúde pública foram parte da configuração do Estado e da construção do corpo social como objeto da ação desse Estado, sendo a saúde uma agenda central nessa produção. A partir da segunda metade do século XVIII, na Europa Ocidental, o disciplinamento dos corpos se deu pelas ações de Higiene e da Polícia Médica. A Revolução Industrial produziu um grande impacto nas condições de vida e de saúde, o que acabou gerando a necessidade de produção de novas respostas já que a organização dos trabalhadores e dos movimentos sociais trouxe para pauta política as condições de trabalho e de vida. Assim, nasceu o que acabou chamando-se de Medicina Social. (PAIM e FILHO, 2000; PAIM, 1992)

Foucault, em seus escritos sobre o nascimento da Medicina Social, nos ajuda a compreender como foi essa produção em três países.

A primeira experiência foi a Medicina de Estado, desenvolvida especialmente na Alemanha no começo do século XVIII, e que criou a noção de ciência do Estado. 
Nesse período, quando estavam sendo criadas as formas de organização do Estado, esses conhecimentos foram sendo criados para alicerçar seu próprio funcionamento. No caso da Alemanha, essa preocupação também se justificava pela estagnação do desenvolvimento econômico alemão e a ocupação da massa burguesa e pensante da sociedade para organização das estruturas estatais.

Houve também o desenvolvimento de uma prática médica que visava a melhoria da saúde da população a partir de uma polícia médica criada em 1764. Teve sua prática centrada em quatro dimensões: a implantação de um sistema de observação da morbidade e seus reflexos nos fenômenos endêmicos e epidêmicos; a normalização da prática e do saber do médico; a organização administrativa para controle da atividade do médico; e a criação da função pública do médico nomeado para se responsabilizar por uma determinada região e população, conformando o papel do médico como gestor/administrador de saúde.

Por todas essas características é que podemos designar a nomenclatura de Medicina de Estado, pois tratou-se de uma produção estatal de ações e serviços de saúde, tanto individuais como coletivas. (FOUCAULT, 2005, p. 80-85)

A segunda experiência foi a da conformação da Medicina Urbana na França num contexto histórico de constituição do corpo urbano enquanto estratégia de unificação do poder urbano/das cidades. Essa organização urbana era necessária especialmente por razões econômicas já que aí multiplicavam-se relações comerciais, havia a conformação de uma zona de mercado e de uma zona de produção. Outra razão existente é a política, pois, com o crescimento da economia de mercado, produziu-se uma plebe em vias de se proletarizar e com grandes chances de se rebelar.

Nesse contexto a estrutura urbana era uma necessidade para a sobrevivência de diversos segmentos. Sem essa estrutura, havia amontoados urbanos e com eles inúmeras doenças e o medo da cidade. Essa inquietude político-sanitária foi controlada a partir do modelo médico e político da quarentena, em que as pessoas deveriam permanecer em casa sob os cuidados de uma autoridade sanitária responsável por bairros. Cabia também a esta autoridade alimentar um sistema de registro geral, verificando se todos estavam vivos, configurando uma espécie de inspetoria. Ao mesmo tempo, era feita uma desinfecção de cada casa 
com ajuda de perfumes queimados. Aí nasceu um modelo de vigilância. Um modelo que previa a purificação da cidade, em que se buscava agir no foco das doenças, com intuito de isolá-lo e evitar sua propagação pela circulação dos indivíduos na cidade, pelo ar ou pela água.

Foi também pela medicina urbana que nasceu o conceito de salubridade, que mais tarde tem desdobramentos importantes para o conceito de sanitarismo. Foi aí também que foi produzida a noção de higiene pública como prática social e política. (FOUCAULT, 2005, p. 86-93)

Foi na Inglaterra que se produziu a Medicina da Força de Trabalho, a medicina dos pobres, dos operários, da força produtiva das nações industriais. Os trabalhadores vivem nas cidades, com precárias condições de subsistência devido a exploração de seu trabalho; com o tempo, tornam-se um perigo em função das revoltas urbanas.

Foi assim que a "Lei dos pobres" deu origem a Medicina Social inglesa, tendo como objetivo desenvolver um controle médico sobre o pobre. Os pobres eram tratados gratuitamente para que os ricos não fossem acometidos por suas doenças. A partir de 1870, a Medicina Social inglesa se estruturou enquanto política de Estado, obrigando todos trabalhadores a se vacinarem; organizando um registro epidemiológico sobre os acontecimentos da saúde de cada um e obrigando a assinatura de declaração de doença perigosa; e localizando os lugares insalubres para extermínio do foco da insalubridade. Nessa política, vêem-se claramente as funções da vigilância sanitária, ambiental e epidemiológica.

Essa medicina dos pobres, com intuito de garantir a força produtiva e evitar os riscos para os mais ricos, levou à produção de subsistemas de saúde, um responsável pelo controle dos pobres (medicina assistencial); outro pelo controle das doenças, epidemias, vacinação em massa (medicina administrativa); e um outro, responsável pela assistência à saúde para quem podia pagar os serviços (medicina privada).

Esse modelo de organização das ações e serviços de saúde levou ao desenvolvimento da Medicina Social que mais tarde também se estruturou enquanto campo científico, pois necessitava desenvolver conhecimento para 
lidar com as diferentes situações sociais que envolviam a saúde da sua população. (FOUCAULT, 2005, p. 93-98)

\begin{abstract}
A medicina é política aplicada no campo da saúde individual e a política nada mais é que a aplicação da medicina no âmbito social, curando-se os males da sociedade. A participação política é a principal estratégia de transformação da realidade de saúde, na expectativa de que das revoluções populares deveria ressaltar democracia, justiça e igualdade, principais determinantes da saúde social. Apesar de desbaratado no plano político, o movimento da Medicina Social gera importante produção doutrinária e conceitual que fornece as bases para os esforços subsequentes de pensar a questão da saúde na sociedade (Paim e Almeida Filho, 1998, p.303).
\end{abstract}

Em outros lugares do mundo, em tempos diferentes a partir de seus processos político-econômico-sociais, foram produzidas medidas semelhantes para o controle da saúde de seus povos. Como a Europa foi o primeiro continente a se estruturar em Estados, ele foi o primeiro continente a enfrentar os problemas acarretados pelo crescimento populacional, criação das cidades e industrialização enquanto modelo produtivo do capitalismo.

Avançando bastante no tempo, já em torno da Segunda Guerra Mundial, destaco o Plano Beveridge, elaborado na Grã-Bretanha e base para muitos países, pela primeira vez, consolidarem ações que garantam o direito à saúde.

É a partir desse período que se produz intenso desenvolvimento tecnológico atrelado à medicina: o desenvolvimento do antibiótico e de novas tecnologias de atenção à saúde. Grandes impactos, mas também aumento de custo. Ao mesmo tempo, a medicina avançava e o seu uso político e econômico, como prática social da saúde, colocava o setor em crise, sendo que decorrem desse período muitas das questões que levaram a mudança na medicina. (FOUCAULT, 2011, p. 374381)

Rosen é outro autor importante no debate sobre a Medicina Social, (1979). Segundo ele é possível entender uma aproximação entre Medicina Social e o conceito de Saúde Coletiva: a saúde do povo é um objeto de inequívoca responsabilidade social; condições econômicas e sociais devem ser submetidas à investigação científica; medidas para promover a saúde e combater a doença devem ser sociais e médicas.

Na produção da Medicina Social, portanto, há também disputas de projeto. Desde as insurreições anti-médicas, a formulação de diferentes teorias para explicar e 
lidar com as doenças do ponto de vista individual e coletivo, até diferentes projetos políticos que reconheciam a produção da saúde como articulada com a produção de arranjos societários econômicos e políticos.

Medicina Social, Medicina Preventiva, Medicina Comunitária são projetos formulados nesse caminho, com alguma influência sobre a organização das ações de saúde, com foco maior ou menor na medicina, na ação sobre os indivíduos e/ou sobre os coletivos.

\begin{abstract}
Diferente da Higiene e da Saúde Pública, a Medicina Preventiva é uma evolução da higiene privada, articulando um conjunto de medidas de prevenção, resultando em condutas que preencheriam uma atitude ausente da prática médica, ou seja, a atitude preventiva e social. Como se fora um partido da nova atitude (integral, preventiva e social), a Medicina Preventiva tornou-se um "centro polarizador de disciplinas não tradicionais dentro da escola médica" (AROUCA, 2003, p. 22).
\end{abstract}

A Medicina Comunitária segundo Donnangelo e Pereira (1979) é um projeto de reforma médica. Projeto que retoma e reorienta questões do campo da prática médica, subordina a prática à dimensão social do processo saúde-doença, superando o corte entre aspectos orgânicos e psicossociais, entre condutas preventivas e curativas, entre prática individual e efeitos coletivos da atenção à saúde. Enfim, é uma resposta à dificuldade da prática médica em responder às necessidades de saúde das populações. Necessidades que, segundo certos projetos políticos, devem ser solucionadas tanto como resposta ao princípio do direito à saúde como por sua significação para o processo de desenvolvimento social.

Bom, mas voltemos ao tema Saúde Pública e Saúde Coletiva.

A Saúde Pública é uma produção internacional - ou seja tem materialidade política e prática em diferentes países do mundo. Pode ser definida a partir do desenvolvimento das ações higienistas, das práticas sanitárias, para o desenvolvimento de políticas públicas que incluem ações coletivas e ações individuais, considerando que ambas devem compor o conjunto de ações que o Estado deve desenvolver. A Saúde Pública, portanto, se estrutura como prática social de cunho político para ação sobre as populações nos processos saúdedoença, tendo sua produção intensificada a partir do final do século XIX, levando em conta a urbanização e as necessidades do modelo agroexportador. 
A Saúde Coletiva se organiza no Brasil posteriormente como campo de saberes e práticas mais amplo que a Medicina Social, Preventiva e Comunitária e mais amplo que a própria Saúde Pública, já que se conformou também como estratégia política de atuação já na resistência contra ditadura, no que se costuma chamar de movimento pela reforma sanitária brasileira. Contrapondose à Saúde Pública existente, a Saúde Coletiva trouxe marcadamente o tema da saúde como direito de cidadania, um conceito ampliado de saúde informado principalmente pela ideia da determinação social do processo saúde-doença, o combate ao modelo médico-hegemônico de organização das práticas de saúde (e daí temas como a equipe de saúde, a interprofissionalidade, o foco no coletivo, etc.).

\section{Um destaque para a Reforma Sanitária no Brasil}

A Reforma Sanitária no Brasil foi produzida no contexto histórico da resistência à Ditadura Militar, que ganhou força a partir da metade dos anos 70. Portanto, o projeto de saúde desse movimento era bem mais amplo que o desenho de um sistema de saúde, era um projeto social para garantir o direito universal à saúde nos seus diversos âmbitos. Foi esse projeto social que mobilizou um conjunto de atores sociais, agentes e instituições, para a formulação e conquista desse direito social e político.

Para compreendermos um pouco como teve início o movimento da Reforma Sanitária devemos recuperar alguns acontecimentos marcantes. Entre eles, a crise da Saúde Pública em São Paulo, que levou a criação do curso para formação de sanitaristas na USP. José da Silva Guedes (MINISTÉRIO DA SAÚDE, 2006) comenta que, em 1975, Leser conta com o apoio do Ministério da Saúde para criar o chamado "curso curto" junto com a Faculdade de Saúde Pública da USP, com o objetivo de formar 400 sanitaristas em curto prazo.

A estratégia para combater a crise da saúde pública em São Paulo com a formação de sanitaristas teve significativa importância para a organização dos atores sociais em torno de questões sobre a saúde que estavam em análise no período. Digamos que houve encontros entre um fato que deveria ser enfrentado e um movimento que desejava questionar os modos de enfrentamento. A partir daí, não foram criados modelos de amortizar a taxa de mortalidade, mas foram 
elaborados métodos de análise dos indicadores relacionando com os campos sociais. Isso resultou em um grande encontro de atores para o campo. Destes encontros, nasceu o Cebes em 1976.

Na segunda metade da década de 1970, enquanto se aprofundam as contradições no âmbito do setor saúde, um renascimento dos movimentos sociais foi produzido, envolvendo a classe trabalhadora, setores populares, estudantes, intelectuais e profissionais da classe média (PAIM, 2008, p. 77).

Ao mesmo tempo em que existia um clima social de revolta com a situação de saúde do país, havia um espaço de formulação sobre a saúde na USP, além dos outros programas de pós-graduação que também buscavam ressignificar a Medicina e a Saúde Pública. Em 1973 foi criado o primeiro programa de pósgraduação em Saúde Coletiva no Instituto de Medicina Social na UERJ, o que indica a convergência dos movimentos desencadeados no plano político e no plano acadêmico para a construção desse novo campo.

Em 1979 foi criada a Abrasco, já com intuito de organizar os processos formativos no novo campo que se estava produzindo, a Saúde Coletiva. Além disso, podemos destacar a participação organizada do Cebes (Centro Brasileiro de Estudos em Saúde) e da Abrasco (Associação Brasileira de Saúde Coletiva) nos movimentos sociais de combate à ditadura.

\footnotetext{
Para Nelson Rodrigues dos Santos, o Cebes é criado para agregar, aglutinar, congregar, conduzir e até comandar o movimento crescente não só de sanitaristas, mas de vários sujeitos estudiosos da saúde. Para ele o Cebes foi o grande aglutinador que politizou o debate, como um movimento suprapartidário. Para José Gomes Temporão, o Cebes foi um espaço muito importante de formulação, divulgação e propaganda da Reforma Sanitária, e a revista foi um veículo dessas idéias (MINISTÉRIO DA SAÚDE, 2006, p. 57 e 58).
}

0 grande objetivo desse movimento social era a conquista da democracia, a construção de um projeto de sociedade que garantisse aos cidadãos um conjunto de direitos sociais universais. Para a saúde o projeto era ousado, pois pretendia a construção de um sistema de saúde universal e que garantisse a integralidade e a equidade do cuidado, assegurando a saúde como direito social e dever do Estado. Era um projeto tipicamente de esquerda, influenciado pelo marxismo que se fortalecia no interior de diferentes correntes do movimento social democrático em luta contra o avanço do capitalismo neoliberal. 
No Brasil as políticas socias tomam proporções importantes no período de redemocratização política, trazendo como pressuposto o chamado "resgate da dívida social" legada pelo regime militar. A esperança de uma redistribuição da renda fazia parte dos cálculos do processo democrático em marcha no período. No começo dos anos 80, os tecnocratas da equipe econômica sob comando de Delfim Neto preferiram evitar a adoção integral de políticas de austeridade, tal como propostas pelo Fundo Monetário Internacional- FMI. A elevação das taxas de juros, os cortes nos gastos públicos, a abertura da economia e a flexibilidade cambial que faziam parte do receituário do FMI, poderiam, se colocados em prática, comprometer a transição política (STOTZ, 2003).

Na saída da ditadura, prevaleceu a idéia da constituição de um Estado de direito em que um "kit básico" de ações sociais foram apresentados como resposta dos governos e se consolidaram como medidas políticas contraditórias para um governo neoliberal, ou mesmo, enquanto estratégias compensatórias diante do avanço liberal do capital.

Nesse sentido, o Estado de direito se constitui numa lógica de construção de pactos sociais participativos, em que os direitos são assegurados ao coletivo e aos indivíduos por meio das políticas públicas que atendem as necessidades e interesses da população nos diversos âmbitos, particulares e coletivos. No caso do Brasil, os direitos foram inscritos no texto constitucional, formalmente assegurados, mas tem sido necessárias lutas e mobilização contínuas para que se efetivem na prática - de modo desigual conforme setores e segmentos.

Habermas dissertou sobre as formas participativas de arranjos do Estado, das formas de comunicação que se estabelecem para garantir os direitos sociais e humanos na conformação desse Estado, que é de direito e pode ser legal. Os foros participativos e as formas comunicacionais são instrumentos do governo das nações, de diálogo com os interesses e necessidades que são satisfeitas pelo conjunto de políticas públicas que constituem o governo, e, assim, o Estado de direito assegura os direitos ao conjunto da população por meio de políticas públicas.

Considerando que a Reforma Sanitária representa um projeto de reforma social e política, poderíamos considerar que vislumbrava uma revolução do modo de vida, não apenas uma reforma parcial como alguns integrantes do movimento 
acreditavam. Essa revolução foi almejada a partir da crítica ao desenvolvimento da sociedade e do Estado para consolidação do capitalismo, acreditava-se serem necessárias mudanças mais profundas na base da constituição social do Estado brasileiro. (PAIM, 2008, p. 38-39)

O movimento sanitário, que agregava um conjunto de atores mobilizados em torno do debate sobre os problemas de saúde e alternativas para combatê-los, produziu intensa mobilização social em torno do direito à saúde. Assim, na $8^{\text {a }}$ Conferência Nacional de Saúde, realizada em 1986, aprovou-se a proposta de sistema nacional de saúde universal, integral e equânime, organizado de forma hierarquizada, regionalizada e seguindo os preceitos da descentralização ${ }^{3}$. 0 conjunto de formulações que compôs o arcabouço constitucional para organização do SUS no Brasil foi inspirado no exemplo e na análise crítica de experiências de outros países.

A Reforma Sanitária se constituiu como um acontecimento histórico que explica a construção do SUS como um projeto social ampliado. Aparece aí também o componente da singularidade da Saúde Coletiva, desse campo que é científico, disciplinar, político, ideológico, militante e social.

O campo da Saúde Coletiva está em aberto e se nutre de muitas idéias para se explicar, traz o componente histórico para a compreensão de muitos fatos políticos e sociais dos episódios marcantes, porém também traz a perspectiva da produção de conhecimentos que hoje se apresentam organizados nos espaços da ciência e da vida.

Os desafios postos pelos sanitaristas, as críticas à Medicina Preventiva, a descrição da crise da Saúde Pública, os desafios identificados na Medicina Comunitária e as iniciativas construídas para superação desses desafios são eventos marcantes dessa história, garantindo, constitucionalmente, o direito à saúde para os brasileiros. A Reforma Psiquiátrica, a proposição da epidemiologia social e o desenvolvimento do planejamento e da gestão em saúde são também

\footnotetext{
${ }^{3} 0$ conceito de descentralização aqui abordado considera-a como um processo de transferência de responsabilidades de gestão para os estados e os municípios, e, procura definir as atribuições específicas de cada esfera de governo. Até hoje, tem operado na lógica de descentralizar responsabilidades operativas do sistema, também descentraliza recursos financeiros mas vinculados a acões, programas e projetos.
} 
importantes marcos da história de constituição do campo da Saúde Coletiva, fortalecidos pelo movimento sanitário.

A Reforma Sanitária mobilizou os atores tanto para a atuação junto aos espaços político-institucionais, quanto para a atuação nos espaços acadêmicos. Em muitos momentos, eram os mesmos atores e instituições que acumulavam papéis, por isso, é difícil separar a história da Reforma Sanitária da história da Saúde Coletiva, da crise da Saúde Pública e da Medicina e da construção do SUS.

Os fatos marcantes dessas histórias foram potencializadores do SUS e da consolidação de um novo campo de conhecimento. Não podem ser confundidos, mas devem ser analisados concomitantemente para identificar os atravessamentos que se colocaram desde esse período histórico até os dias de hoje.

\section{O nascimento da Saúde Coletiva: conformação de um campo engravidado pela Saúde Pública e pela Reforma Sanitária Brasileira}

Na América Latina como um todo, a Saúde Pública se consolidou como grande campo de conhecimento, prática e política. No entanto, no Brasil, com o fim da ditadura e o fortalecimento das questões sociais dentro do cenário político e institucional do Estado, as ciências sociais e humanas foram introduzidas no campo de forma incisiva levando à criação de um novo campo, mais amplo, chamado de Saúde Coletiva.

Em diferentes países, houve a criação de cursos de pós-graduação em Medicina Social e a revisão das abordagens predominantes em centros universitários e de Saúde Pública. No Brasil, esse movimento se inicia, como já dito, com a criação da pós em Medicina Social no IMS-UERJ. Posteriormente, esse movimento se expandiu, concretizando o movimento científico para consolidação dessa nova ou remanufaturada ciência. (LEAL, 2009)

Conforme Paim descreve, nos anos 70, os mesmos atores que lutavam pela Reforma Sanitária eram os autores que pensavam o campo da Saúde Coletiva. Todos tinham uma posição anti-capitalista, eram socialistas e alguns com opção marxista e eram os formuladores desses processos históricos. Sérgio Arouca, Madel Luz, Hésio Cordeiro, Cecília Donnangelo, etc, são alguns dos personagens que atuaram nessa história e que buscaram um novo projeto social para a saúde. 
No bojo desse movimento político, houve um debate importante que demonstrou que a Medicina Preventiva era "filha da Higiene", ou seja, centrava suas ações na luta politico-ideológica contra a intervenção do Estado na saúde e contra as transformações sociais necessárias à melhoria da situação de saúde, em contraposição à Saúde Pública e a Medicina Social.

Segundo a tese de Arouca, a Medicina Preventiva possibilitou uma reorganização do conhecimento médico, uma nova forma de pensar a prática médica, a partir do estabelecimento de um conjunto de conceitos estratégicos que pretendiam mudanças da própria prática médica, como, também, das condições de saúde da população.

Esse debate da tese do Arouca que produz a crítica à prática do médico foi feito colocando em questão essa prática, inclusive a dos ditos preventivistas. Pois, se em algum momento, o discurso preventivista esteve ligado à crítica sobre a formação dos profissionais médicos e a necessidade de se ter uma nova atitude, integral, preventiva e social, mais tarde, pode ser vista como aspecto importante a ser trabalhada pelo conjunto das mudanças que eram necessárias na saúde, compreendendo-a como limitada ao ato do fazer do médico.

O discurso preventivista foi objeto de estudo nos cursos básicos e regionalizados de Saúde Pública da Escola Nacional de Saúde Pública, e nos demais cursos de pós-graduação da área, bem como foi importante no debate do Cebes. Sendo que, em 1978, no Encontro Nacional de Pós-Graduação em Saúde Coletiva, as críticas à Medicina Preventiva e à Medicina Comunitária compuseram o processo de criação da Abrasco. (PAIM, 2003b, p. 151-154)

Mas havia outros atores e outros projetos também em cena, tanto que:

Não é possível analisar exaustivamente a contribuição da tese
do Arouca no desenvolvimento das práticas política, teórica e
científica do Cebes e da Abrasco, enquanto sujeitos coletivos, e
seus intelectuais orgânicos. Também não se podem examinar
inteiramente as suas repercussões na constituição do
movimento sanitário, na proposta de criação do SUS (...) outros
sujeitos, saberes e práticas agregaram-se e se articularam na
tríade da Saúde Coletiva: conhecimento, consciência sanitária e
organização do movimento sanitário (PAIM, 2003b, p.154-
155).

Em 1979, a Abrasco foi organizada para agregar os diferentes atores e instituições portadoras de saberes sobre os objetos que hoje compõem um único 
campo. Ela incentivou a organização de programas de pós-graduação em Saúde Coletiva e pretendeu organizar a produção de conhecimento no campo.

Após 1988, enquanto a criação do SUS foi palco de consolidação das inúmeras lutas que compunham a carta de reinvindicação do movimento sanitário, o próprio sistema de saúde servia como laboratório para avaliação e reconstrução dos conhecimentos que embasaram sua construção.

Ao observarmos as intercessões entre os espaços de produção de saúde, notaremos que as políticas públicas foram desdobramentos dos movimentos da Reforma Sanitária e de criação do SUS. Nesse período é possível afirmar que os espaços acadêmicos forneceram importantes elementos para as políticas e arranjos inicialmente experimentados na construção do SUS.

Os desdobramentos posteriores - na construção do SUS e do campo da saúde coletiva - são objeto de polêmica e disputa:

A Reforma Sanitária, enquanto fenômeno histórico e social, poderia ser analisada como idéia-proposta-projetomovimento-processo: idéia que se expressa em percepção, representação, pensamento inicial; proposta como conjunto articulado de princípios e proposições políticas; projeto enquanto síntese contraditória de políticas; movimento como articulação de práticas ideológicas, políticas e culturais; processo enquanto encadeamento de atos, em distintos momentos e espaços que realizam práticas sociais, econômicas, políticas, ideológicas e simbólicas (PAIM, 2008, p. 36).

Será que estávamos diante da dita "nova Saúde Pública"? - conforme define Oliveira (2005), a nova abordagem da Saúde Pública, com sua ênfase na natureza multidimensional dos problemas relacionados à saúde, juntamente com a ênfase na promoção da escolha informada, abre o campo da promoção da saúde das populações a diversos tipos de disciplinas e especialistas.

$\mathrm{Ou}$ estamos testemunhando as disputas que se dão entre os campos de conhecimento na busca da melhor explicação para os fenômenos biológicos, sociais, políticos, econômicos?

A constituição da Saúde Coletiva, tendo em conta os seus fecundos diálogos com a Saúde Pública e com a Medicina Social, tal como vem se concretizando nas duas últimas décadas, permite uma delimitação compreensivelmente provisória desse campo científico, enquanto campo de conhecimento e âmbito de práticas. Enquanto campo de conhecimento, a saúde coletiva contribui com o estudo do fenômeno saúde/doença em populações enquanto processo social; investiga a produção e distribuição das doenças na sociedade como processos de produção e reprodução social; analisa as práticas de saúde 
(processo de trabalho) na sua articulação com as demais práticas sociais; procura compreender, enfim, as formas com que a sociedade identifica suas necessidades e problemas de saúde, busca sua explicação e se organiza para enfrentá-los (PAIM, ALMEIDA FILHO, 1998, p.309).

Sônia Fleury afirma que, os atores em cena no movimento sanitário tentaram fugir da discussão sobre se a Medicina era ou não era social, sobretudo pela influência de Foucault, afirmando, assim, que ela sempre foi social. 0 objeto em questão, portanto, não era um corpo individual, mas um corpo social. E, para aprofundar essa compreensão, foi analisado o lugar social da prática médica, do ponto de vista dos serviços e da estrutura política, e da determinação social do processo saúde-doença, o que levou a um outro tipo de visão da determinação social da doença, uma visão marxista, a partir da qual se identificava que a estrutura de classes se reproduzia nesse campo do processo saúde-doença.

Nunes apud Campos (2000a, p. 222) descreveu que o termo Saúde Coletiva passou a ser utilizado, no Brasil, em 1979, quando um grupo de profissionais, oriundos da Saúde Pública e da Medicina Preventiva e Social procuraram fundar um campo científico com uma orientação teórica, metodológica e política que privilegiava o social como categoria analítica.

Como se vê, por vezes, ocorre uma sobreposição entre a idéia do campo da saúde coletiva e do Movimento da Reforma Sanitária. Essa é uma riqueza de uma história tipicamente brasileira, pois conta com o referencial político e ideológico da luta por uma mudança no sistema de saúde brasileiro, ao mesmo tempo em que é permitido construir um campo que se traduz em saberes e práticas agenciados pelo movimento e com autonomia para se constituir também enquanto ciência. (LEAL, 2009)

A Saúde Coletiva é, simultaneamente, um campo científico e um âmbito de práticas, contribuindo com a Reforma Sanitária Brasileira mediante produção de conhecimentos e sua socialização junto aos movimentos sociais. Como campo científico, distancia-se da Saúde Pública institucionalizada e, como práxis, tem a possibilidade de radicalizar seus compromissos históricos com o povo, com as pessoas, com as classes dominadas (Paim, 2007, p.2521).

Entrelaça-se aqui, a questão da política na e da Saúde Coletiva. Em outros termos, na medida em que existe uma articulação estreita entre a produção do conhecimento, concebida enquanto uma prática política, e a estratégia política real do movimento sanitário brasileiro, esta acabou por imprimir a marca àquela, que se configura, então, como um saber militante (COHN, 1992, p. 99-100). 
A Saúde Coletiva é formada a partir dos movimentos da Medicina Social e da Saúde Pública, fabricando como objeto da sua atuação um projeto de mudança social, que incluía produção da saúde como direito, a transformação das condições de vida e a construção de um sistema de saúde, a partir de uma perspectiva que considera as relações entre saúde e sociedade. Está, portanto, fundamentada a partir da formulação do movimento sanitário e desse projeto político-ideológico que propiciou novos olhares para os objetos de indagação, produzindo conhecimento a partir desse contexto e numa lógica que trazia como critério de investigação e produção o olhar ampliado para as questões da saúde. (ABRASCO, 1985, p. 37-38)

Emerson Merhy afirma não ser possível definir que a Saúde Coletiva é mais "ciência" porque agrega ao saber da Saúde Pública mais qualidade e porque introduz o materialismo histórico; ou seja, questiona a ideia de que novos saberes ampliariam a verdade da Saúde Coletiva em relação à verdade da Saúde Pública. Havia uma pretensão de Verdade no movimento que deu início às formulações do campo da Saúde Coletiva, mas não para ser ciência, mas para ser intervenção social. Portanto, para entender a Saúde Coletiva como campo de ciência, é necessário compreender a Saúde Coletiva como um campo de militância e a sua conformação como território da militância social.

Paim (2006) defende que a Saúde Coletiva pode ser vista como um movimento ideológico que gerou um campo científico e um âmbito de práticas contrahegemônicas, com diferenças significativas em relação à Saúde Pública e ao modelo médico hegemônico. Enquanto a Saúde Coletiva se afirmava como campo científico e âmbito de práticas, contribuiu na formulação do projeto da Reforma Sanitária Brasileira e na construção de sua dimensão institucional - o Sistema Único de Saúde (SUS) (PAIM, 2006, p. 144).

Camargo Junior (2003) afirma que uma das características mais significativas da Saúde Coletiva, tomada como campo disciplinar, é a convivência entre a intervenção e a reflexão, dimensões sinalizadas no jargão do campo como "serviço" e "academia". Partindo do pressuposto de que a Saúde Coletiva no Brasil se conformou enquanto campo científico em determinado momento histórico, consideramos que a própria definição de campo científico por vezes é 
insuficiente para caracterizar o movimento político-ideológico-intelectual particularmente brasileiro.

Nessa perspectiva, também é importante lembrar que, ao longo dos anos, houve um movimento de afastamento entre as vertentes teórica e política da Saúde Coletiva, já apontando dificuldades para tornar efetiva a relação interativa entre o plano da política e o plano da produção de conhecimento.

Uma das possíveis explicações é de que não era suficiente para os atores que entraram na cena política o conjunto de formulações teóricas acumuladas, e, talvez, isso também tenha ocorrido reciprocamente. Essa foi uma das interrogações orientadoras deste estudo. 
Efeitos... colaterais a partir do mergulho nos bancos de teses e nos periódicos

Aqui vou apresentar questões relevantes, que escapam ao objeto central do estudo, mas que vale a pena apontar e explorar mais.

\section{O encontro com as palavras-chave}

Quando da exploração dos bancos de teses e dissertações bem como nos periódicos, iniciamos pelo campo das palavras-chave, pois acreditavámos que seriam úteis para identificação do tema.

No processo de coleta notamos uma certa fragilidade na definição das plavraschave de cada uma das produções. Esperavámos que essas palavras-chave fossem pertencentes ao banco de Descritores em Ciência da Saúde (Decs), contudo, não foi o que encontramos

Segundo definição da Wikipédia (2014),

O DeCS é a sigla para Descritores em Ciências da Saúde, uma versão ampliada trilíngue do MeSH [Medical Subject Headings] da U.S. National Library of Medicine, que originalmente foi construído em inglês. Trata-se de um vocabulário controlado, mundialmente utilizado para representar o assunto dos documentos das principais bases de dados em saúde como MEDLINE, LILACS, Cochrane. Contém mais de 30 mil conceitos das 16 categorias do MeSH, e mais 4 categorias próprias: Saúde Pública, Homeopatia, Ciências e Saúde e Vigilância Sanitária. (Wikipédia, 2014, disponível em: http://wiki.bireme.org/pt/index.php/DeCS__Descritores_em_Ci\%C3\%AAncia_da_Sa\%C3\%BAde).

O DeCS foi adotado com base em um critério de internacionalização da circulação da produção acadêmica. Os critérios internacionais partem da lógica produtiva da medicina e das ciências biomédicas, no entanto essa lógica de indexação da medicina foi expandida para toda a área da saúde. A Biblioteca Virtual da Saúde (BVS) utiliza a terminologia em saúde do Decs para descrever os artigos científicos indexados nas bases de dados LILACS e MEDLINE. No entanto, não foi essa a realidade encontrada na maioria das produções aqui estudadas.

Fizemos um primeiro exercício de identificar os possíveis descritores constantes no Decs para analisar se por seu intermédio identificaríamos a produção desejada. Também fez-se um exercício de levantamento dos grandes temas e 
possíveis idéias-chave que estariam presentes nas produções que seriam selecionadas. Com essa lógica, produziu-se a Tabela abaixo:

Tabela 8: Seleção de Palavras-chave e idéias-chave, Descritores e Possíveis classificações segundo grandes áreas de debate

\begin{tabular}{|c|c|c|c|}
\hline $\begin{array}{l}\text { Grandes Áreas de } \\
\text { Debate }\end{array}$ & $\begin{array}{l}\text { Palavras-chave e idéias-chave } \\
\text { esperadas na pesquisa }\end{array}$ & Descritores da base Decs & $\begin{array}{c}\text { Sub- } \\
\text { classificações } \\
\text { Temáticas }\end{array}$ \\
\hline Educação na Saúde & $\begin{array}{l}\text { educação, formação, qualificação, } \\
\text { processos educativos, } \\
\text { desenvolvimento dos } \\
\text { trabalhadores, ensino, educação } \\
\text { permanente, educação } \\
\text { continuada, integralidade na } \\
\text { formação, ensino em saúde, } \\
\text { ensino médico, pólos de educação } \\
\text { permanente, comissões de } \\
\text { integração ensino-serviços, } \\
\text { ativadores da mudança, } \\
\text { integração docente-assistencial, } \\
\text { VER-SUS, aprender-SUS, ensina- } \\
\text { SUS, integração ensino-serviço- } \\
\text { comunidade, residência } \\
\text { multiprofissional, residência } \\
\text { médica, escolas }\end{array}$ & $\begin{array}{c}\text { administração de recursos } \\
\text { humanos, educação continuada, } \\
\text { educação médica, educação } \\
\text { médica continuada, Educação } \\
\text { de Pós-Graduação em Medicina, } \\
\text { Educação de Graduação em } \\
\text { Medicina, Educação em } \\
\text { Enfermagem, Educação } \\
\text { Continuada em Enfermagem, } \\
\text { Educação de Pós-Graduação em } \\
\text { Enfermagem, Educação em } \\
\text { Farmácai, Educação } \\
\text { Continuada em Farmácia, } \\
\text { Educação de Pós-Graduação em } \\
\text { Farmácia, Educação } \\
\text { Profissionalizante, Educação } \\
\text { em Veterinária, Apoio ao } \\
\text { Desenvolvimento de Recursos } \\
\text { Humanos, Educação em Saúde, } \\
\text { Educação Superior, Educação } \\
\text { Profissional em Saúde Pública, } \\
\text { Política de Educação Superior }\end{array}$ & $\begin{array}{c}\text { política, } \\
\text { dispositivos e } \\
\text { estratégias, } \\
\text { práticas, } \\
\text { profissões }\end{array}$ \\
\hline Atenção Básica & $\begin{array}{l}\text { atenção básica, atenção primária, } \\
\text { saúde da família, equipe, } \\
\text { território, agentes comunitários } \\
\text { de saúde, PACS, PSF, ESF, NASF, } \\
\text { apoio, apoio institucional, } \\
\text { unidade básica de saúde, médico } \\
\text { de família }\end{array}$ & $\begin{array}{c}\text { governança clínica, } \\
\text { gerenciamento da prática } \\
\text { profissional, assistência } \\
\text { centrada no paciente, } \\
\text { visitadores domiciliares }\end{array}$ & $\begin{array}{l}\text { política, } \\
\text { serviços, } \\
\text { estratégias, } \\
\text { equipe, prática }\end{array}$ \\
\hline $\begin{array}{c}\text { Regionalização/ } \\
\text { Gestão } \\
\text { Interfederativa }\end{array}$ & $\begin{array}{l}\text { regionalização, pacto, COAP, } \\
\text { descentralização, intergestores, } \\
\text { relação intergestores, articulação } \\
\text { regionalizada, CIR, CGMR, NOB, } \\
\text { NOAS, colegiados de gestão } \\
\text { regional, colegiados } \\
\text { intergestores, CIB, interfederativo }\end{array}$ & $\begin{array}{c}\text { Regionalização, } \\
\text { Descentralização, } \\
\text { Desenvolvimento Regional }\end{array}$ & $\begin{array}{c}\text { política, } \\
\text { instrumentos, } \\
\text { práticas, } \\
\text { espaços }\end{array}$ \\
\hline
\end{tabular}

No entanto, ao longo do processo de coleta das informações, constatamos um enorme afastamento entre as palavras-chave presentes nas produções e os descritores existentes no Decs.

Muitas produções não utilizam o Decs para definir as palavras-chave!!!!

Fiz, então, um processo comparativo entre as palavras-chave encontradas nas produções selecionadas e os descritores encontrados no Decs relativos as 
temáticas aqui estudadas. Observem as duas tabelas abaixo que identificam um pouco desse movimento de desencontro:

Tabela 9: Palavras-chave, categorias utilizadas na pesquisa e termos utilizados igualmente em ambas as classificações

\begin{tabular}{|c|c|c|c|}
\hline $\begin{array}{c}\text { Grandes } \\
\text { Áreas de } \\
\text { Debate }\end{array}$ & $\begin{array}{c}\text { Palavras-chave e idéias- } \\
\text { chave }\end{array}$ & Categorias Utilizadas & $\begin{array}{c}\text { Palavras- } \\
\text { chave } \\
\text { encontradas } \\
\text { semelhantes } \\
\text { as categorias }\end{array}$ \\
\hline $\begin{array}{l}\text { Educação } \\
\text { Permanente }\end{array}$ & $\begin{array}{c}\text { educação, formação, qualificação, } \\
\text { processos educativos, } \\
\text { desenvolvimento dos trabalhadores, } \\
\text { ensino, educação permanente, } \\
\text { educação continuada, integralidade na } \\
\text { formação, ensino em saúde, ensino } \\
\text { médico, pólos de educação } \\
\text { permanente, comissões de integração } \\
\text { ensino-serviços, ativadores da } \\
\text { mudança, integração docente- } \\
\text { assistencial, VER-SUS, aprender-SUS, } \\
\text { ensina-SUS, integração ensino-serviço- } \\
\text { comunidade, residência } \\
\text { multiprofissional, residência médica, } \\
\text { escolas }\end{array}$ & $\begin{array}{l}\text { Formação e Educação, Graduação, Experiências } \\
\text { de formação, Diversão dos cenários de prática, } \\
\text { Metodologia de ensino, Desenho curricular, } \\
\text { Formação Docente, Ensino Técnico, } \\
\text { Especialização, Processos Informais, Avaliação } \\
\text { da formação, Preceptoria/Tutoria/Supervisão, } \\
\text { EPS, Experiências de EPS, apoio/matriciamento, } \\
\text { ferramentas de gestão do trabalho, Educação } \\
\text { Continuada, EAD/Telessaúde, Formação de } \\
\text { Gestores, Extensão Universitária, Residência de } \\
\text { Medicina de Família e Comunidade, Residências } \\
\text { Médicas, Residências Multiprofissionais, VER- } \\
\text { SUS, Política de EPS, Pólos e outros espaços } \\
\text { colegiados (CIES, etc), Política de EPS (Pólos de } \\
\text { EPS e Pólos de SF), Pró-Saúde, Promed, Pet- } \\
\text { Saúde, Aprender-SUS, Escolas de Saúde Pública } \\
\text { e de ETSUS, Avaliação da política, Análise da } \\
\text { política, estratégia de gestão }\end{array}$ & $\begin{array}{l}\text { Metodologia do } \\
\text { ensino, Preceptoria, } \\
\text { Residência Médica } \\
\text { em Pediatria, } \\
\text { política de educação } \\
\text { profissional em } \\
\text { saúde, educação } \\
\text { permanente em } \\
\text { saúde, Formação de } \\
\text { recursos humanos } \\
\text { em saúde, extensão } \\
\text { universitária, } \\
\text { Escolas de Saúde } \\
\text { Pública, avaliação da } \\
\text { formação }\end{array}$ \\
\hline $\begin{array}{l}\text { Atenção } \\
\text { Básica }\end{array}$ & $\begin{array}{c}\text { atenção básica, atenção primária, } \\
\text { saúde da família, equipe, território, } \\
\text { agentes comunitários de saúde, PACS, } \\
\text { PSF, ESF, NASF, apoio, apoio } \\
\text { institucional, unidade básica de saúde, } \\
\text { médico de família }\end{array}$ & $\begin{array}{l}\text { Doenças e agravos prioritários (hipertensão, } \\
\text { diabetes, tuberculose, etc), resultado de ações } \\
\text { de saúde, processo de trabalho, política sobre } \\
\text { doenças e agravos prioritários, usuário (ponto } \\
\text { de vista), outras coisas sobre doenças e agravos } \\
\text { prioritários, violência, AIDS/HIV e outras } \\
\text { doenças sexualmente transmissíveis, vigilância } \\
\text { em saúde, Trabalho, atuação de categorias } \\
\text { profissionais, equipe de saúde, processo de } \\
\text { trabalho, acolhimento, NASF, } \\
\text { apoio/matriciamento, outras ferramentas de } \\
\text { gestão do trabalho, ACS, micropolítica, } \\
\text { ambiente/condições de trabalho, Perspectiva do } \\
\text { usuário, adesão a ações e programas, ponto de } \\
\text { vista/avaliação do usuário, AB e redes de } \\
\text { cuidado, Integralidade, Articulação dos serviços } \\
\text { - rede, dispositivos de gestão do cuidado, } \\
\text { produção do cuidado, } \\
\text { encaminhamento/referência, resolutividade, } \\
\text { grupos e educação em saúde, promoção da } \\
\text { saúde, diversificação de ofertas de cuidado } \\
\text { (saúde mental, práticas integrativas, etc), ações } \\
\text { programáticas (bucal, nutrição, assist. Farmac., } \\
\text { etc), biopolítica, ciclos de vida, resultado de } \\
\text { ações de saúde, acesso as ações e serviços de } \\
\text { saúde, Gestão, gestão do trabalho, processo de } \\
\text { trabalho, economia/financiamento, modelo de } \\
\text { atenção, gestão local, controle social, } \\
\text { planejamento, avaliação, oferta e demanda, } \\
\text { encaminhamento/referência, cobertura, } \\
\text { micropolítica, T.I., contratualização, } \\
\text { Intersetorialidade, Bolsa Família, Escola, } \\
\text { Violência, Intersetorialidade de modo mais } \\
\text { geral, Política de Atenção Básica }\end{array}$ & $\begin{array}{l}\text { Diversidade, } \\
\text { Economia da Saúde, } \\
\text { Processo de } \\
\text { trabalho, Vigilância } \\
\text { da saúde, Trabalho, } \\
\text { Processo de } \\
\text { trabalho, } \\
\text { integralidade, } \\
\text { Promoção da Saúde, } \\
\text { Processo de } \\
\text { trabalho, Modelo de } \\
\text { atenção, } \\
\text { Intersetorialidade - } \\
\text { pt, } \\
\text { Intersetorialidade - } \\
\text { pt, Equipe de } \\
\text { Enfermagem, gestão, } \\
\text { financiamento } \\
\text { AIDS (Doença) - } \\
\text { Recife (PE), Apoio } \\
\text { Matricial, Ambiente } \\
\text { de Trabalho, Clinica } \\
\text { ampliada, Ciclos de } \\
\text { política, Avaliação, } \\
\text { Cobertura, Bolsa } \\
\text { Família, Avaliação } \\
\text { em Saúde }\end{array}$ \\
\hline $\begin{array}{l}\text { Regionalizaçã } \\
\text { o/Gestão } \\
\text { Interfederati } \\
\text { va }\end{array}$ & $\begin{array}{l}\text { regionalização, pacto, COAP, } \\
\text { descentralização, intergestores, } \\
\text { relação intergestores, articulação } \\
\text { regionalizada, CIR, CGMR, NOB, NOAS, } \\
\text { colegiados de gestão regional, } \\
\text { colegiados intergestores, CIB, } \\
\text { interfederativo }\end{array}$ & $\begin{array}{l}\text { Regionalização, Descentralização, } \\
\text { Municipalização, Colegiados Regionais, Relação } \\
\text { Interfederativa, Disputas/conflitos políticos, } \\
\text { articulação intergestores, espaços colegiados } \\
\text { (CIB, CIT, colegiados, etc), Redes Regionalizadas, } \\
\text { Financiamento, Planejamento, Instrumentos da } \\
\text { política, normas operacionais, pacto, decreto, } \\
\text { consórcios, avaliação em saúde, Relação } \\
\text { público-privado, Contratualização, Contratos, } \\
\text { Relações políticas, Aspectos políticos e } \\
\text { operativos do sistema de saúde (modelos de } \\
\text { gestão e atenção), Modelagens de gestão (apoio, } \\
\text { estratégias inovadoras, etc), Acesso e } \\
\text { Integralidade (produção do cuidado) }\end{array}$ & $\begin{array}{l}\text { Planejamento, } \\
\text { municipalização, } \\
\text { financiamento, } \\
\text { Contratos, } \\
\text { Descentralização, } \\
\text { Colegiado de gestão } \\
\text { regional, Consórcio } \\
\text { Intermunicipal de } \\
\text { Saúde - pt, Contratos }\end{array}$ \\
\hline
\end{tabular}


Tabela 10: Descritores, descritores semelhantes as categorias temáticas, palavras-chave semelhantes aos descritores

\begin{tabular}{|c|c|c|c|}
\hline $\begin{array}{l}\text { Grandes } \\
\text { Áreas de } \\
\text { Debate }\end{array}$ & Descritores & $\begin{array}{c}\text { Descritores } \\
\text { encontrados } \\
\text { semelhantes as } \\
\text { categorias }\end{array}$ & $\begin{array}{l}\text { Palavras-chave semelhantes aos } \\
\text { Descritores }\end{array}$ \\
\hline $\begin{array}{l}\text { Educação } \\
\text { Permanente }\end{array}$ & $\begin{array}{c}\text { administração de recursos } \\
\text { humanos, educação continuada, } \\
\text { educação médica, educação } \\
\text { médica continuada, Educação } \\
\text { de Pós-Graduação em Medicina, } \\
\text { Educação de Graduação em } \\
\text { Medicina, Educação em } \\
\text { Enfermagem, Educação } \\
\text { Continuada em Enfermagem, } \\
\text { Educação de Pós-Graduação em } \\
\text { Enfermagem, Educação em } \\
\text { Farmácai, Educação } \\
\text { Continuada em Farmácia, } \\
\text { Educação de Pós-Graduação em } \\
\text { Farmácia, Educação } \\
\text { Profissionalizante, Educação } \\
\text { em Veterinária, Apoio ao } \\
\text { Desenvolvimento de Recursos } \\
\text { Humanos, Educação em Saúde, } \\
\text { Educação Superior, Educação } \\
\text { Profissional em Saúde Pública, } \\
\text { Política de Educação Superior }\end{array}$ & $\begin{array}{c}\text { Educação } \\
\text { Profissional em } \\
\text { Saúde Pública, } \\
\text { educação continuada, } \\
\text { administração de } \\
\text { recursos humanos }\end{array}$ & $\begin{array}{l}\text { Administração de Recursos Humanos, } \\
\text { Administração de Recursos Humanos em } \\
\text { Saúde, Educação Continuada, Educação } \\
\text { Continuada/história, Educação } \\
\text { Continuada/recursos humanos, } \\
\text { Educação de graduação em medicina, } \\
\text { educação e prática médica, Educação } \\
\text { Médica, educação médica - Brasil, } \\
\text { Educação Médica/recursos humanos, } \\
\text { Educação Médica/tendências, Educação } \\
\text { em Enfermagem, Educação em } \\
\text { Enfermagem/recursos humanos, } \\
\text { Educação em Farmácia/recursos } \\
\text { humanos, educação farmacêutica, } \\
\text { Educação Profissional em Saúde Pública, } \\
\text { Educação Profissional em Saúde } \\
\text { Pública/recursos humanos, Educação } \\
\text { Profissionalizante, Educação } \\
\text { Profissionalizante/recursos humanos, } \\
\text { Educação, Apoio ao Desenvolvimento de } \\
\text { Recuros Humanos, Educação em saude, } \\
\text { Educação em Saúde/métodos, Educação } \\
\text { em Saúde/organização \& administraçäo, } \\
\text { Educação em Saúde/recursos humanos, } \\
\text { Educação em Saúde/recursos humanos, } \\
\text { Educação em Saúde/utilizaçäo } \\
\text { Educação Superior, política de educação } \\
\text { profissional em saúde, Política Nacional } \\
\text { de Educação Permanente em Saúde }\end{array}$ \\
\hline $\begin{array}{l}\text { Atenção } \\
\text { Básica }\end{array}$ & $\begin{array}{l}\text { governança clínica, } \\
\text { gerenciamento da prática } \\
\text { profissional, assistência } \\
\text { centrada no paciente, } \\
\text { visitadores domiciliares }\end{array}$ & $\begin{array}{l}\text { administração de } \\
\text { recursos humanos, } \\
\text { Educação } \\
\text { Profissional em } \\
\text { Saúde Pública }\end{array}$ & $\begin{array}{l}\text { governança, gerência de serviços de } \\
\text { saúde, Assistência à Saúde, Visita } \\
\text { domiciliar, Visitadores domiciliares }\end{array}$ \\
\hline $\begin{array}{l}\text { Regionalizaçã } \\
\text { o/Gestão } \\
\text { Interfederati } \\
\text { va }\end{array}$ & $\begin{array}{c}\text { Regionalização, } \\
\text { Descentralização, } \\
\text { Desenvolvimento Regional }\end{array}$ & $\begin{array}{l}\text { Descentralização, } \\
\text { Regionalização }\end{array}$ & $\begin{array}{c}\text { Regionalização, Regionalização - pt, } \\
\text { Regionalização da Saúde, regionalização } \\
\text { dos sistema de saúde, } \\
\text { Regionalização/hierarquização, } \\
\text { Regionalização/organizaçäo \& } \\
\text { administraçäo, Descentralização, } \\
\text { descentralizção da política de saúde, } \\
\text { Descentralização da vigilância sanitária, } \\
\text { Descentralização/organizaçäo \& } \\
\text { administraçäo, Planejamento Regional } \\
\text { de Saúde }\end{array}$ \\
\hline
\end{tabular}

No conjunto de artigos, teses e dissertações selecionadas e estudadas, foram identificadas 960 palavras-chave diferentes e, na comparação com o conjunto dos descritores do DeCs identificados pela temática abordada, identificamos 47 palavras-chave semelhantes a eles. Ou seja, menos de $5 \%$ do total das palavraschave utilizadas nas produções do campo pertencem ao banco do DeCs. Interessante essa constatação!

Algumas explicações nos ocorreram: o Decs é construído na lógica da biomedicina e essa lógica não se aplica bem à Saúde Coletiva! As palavras-chave não são neutras, são construídas com base em certos referenciais teórico- 
conceituais, daí a recusa de muitos autores a adotarem esse vocabulário. Educação Permanente não é o mesmo que educação continuada. Atenção não é o mesmo que assistência. E por aí vai.

Por outro lado, pudemos constatar que vários neologismos são produzidos na definição das palavras-chave. Novos conceitos em busca de novas expressões? Isso é um problema! Muitas pesquisas que envolvem pesquisa e/ou revisão bibliográfica baseiam-se em buscas de descritores. Portanto, muita coisa se perde! Esse é um tema para debate e providências no campo das informações bibliográficas!

\section{O processo de construção das categorias temáticas}

Após as leituras sobre as políticas a serem estudadas, foi feita uma definição inicial de um conjunto de possíveis categorias classificadoras. Tal lista foi um ensaio a partir da expectativa sobre o que era desejado encontrar como produções do campo. Essa lista foi importante mas não suficiente e, ao longo do processo de coleta de dados e, posteriormente, com o processo de categorização, foram sendo incluídos mais temas a essa lista. Tal lista encontra-se na Tabela 4 anexada anteriormente.

As categorias temáticas definiram os grandes temas de cada uma das políticas, contudo, para aprofundar as análises, foram construídas as sub-categorias. Ao observar que algumas produções traziam temas diferentes mas igualmente relevantes para a análise do objeto dos estudos, defimos que seriam utilizadas 2 categorias temáticas para cada produção. Uma assumiria o papel de expressar o tema principal e a segunda daria destaque ao tema secundário.

É interessante destacar que nem todas as categorias e sub-categorias construídas, foram encontradas nas produções selecionadas. As categorias referentes a política de Educação na Saúde foram as menos utilizadas, já que poucas apresentaram ocorrências significativas. Isso indica certa tendência na formulação das questões de estudo e pesquisa sobre essa política. Vamos abordar mais sobre isso adiante. 


\section{A metodologia de análise de políticas e a definição do olhar a partir do entendimento da política como dispositivo}

O encontro com a metodologia de análise de políticas construída por Stephen Ball foi fundamental para o desenvolvimento deste estudo. Ball modifica a ideia do ciclo de políticas, tradicionalmente compreendido como composto por momentos estanques: formulação, implementação e avaliação. Segundo a compreensão, as disputas estão concentradas no momento de definição do problema e de formulação dos modos de enfrentá-lo.

Ball, partindo das ideias de Foucault, reconhece que há disputas o tempo todo na produção das políticas: o tempo todo há formulação/produção de novos textos. Assim, há produção de texto em todos os contextos de produção de uma política. De acordo com essa formulação, este estudo coloca em diálogo dois vetores de produção de texto: o texto das políticas em si e os textos sobre as políticas produzidos pela academia/saúde coletiva. Esse poderia ser um momento de disputa de projetos, se a academia se colocar também como ator social que formula!!

A compreensão da política como dispositivo também foi fundamental para ajustar o olhar durante todo o processo investigativo deste estudo. Ajudou a questionar o próprio referencial de política adotado por diversos atores sociais, assim como a questionar a sua funcionalidade comumente chamada de indutora. Seria a política indutora ou produtora? Seria um convite á invenção ou um dispositivo aprisionante? Seria a política emancipatória ou doutrinária? Essas questões nortearam o processo de análise. 
A partir do olhar sobre a produção das políticas: pontos de encontro entre o SUS e a Saúde Coletiva

\section{A escolha de uma perspectiva para o olhar sobre a produção das políticas}

Como já comentado, para desenvolver a análise proposta o primeiro movimento realizado foi a busca de uma perspectiva teórica e conceitual que dialogassecom o movimento analítico proposto pela pesquisa.

Segundo Mainardes et.al. (2011), há vários modelos lineares de formulação e análise de políticas que buscam aferir e avaliar o processo e o impacto da implementação das políticas sem tomar o contexto como um elemento analítico importante. Segundo o mesmo autor, há outras perspectivas que consideram que as políticas podem ser entendidas como processo e produto que envolvem articulações entre textos e processos, considerando que o processo político é complexo e envolve variados contextos.

No segundo grupo econtram-se diferentes perspectivas teóricas, tais como o materialismo histórico e dialético, as teorias estruturalistas, as teorias pósestruturalistas, as teorias feministas e as teorias pluralistas, sendo que as pósestruturalistas e pluralistas se destacam por alguns elementos que podem ser explicitados.

\footnotetext{
Os pós-estruturalistas consideram a ação dos sujeitos um aspecto crucial para a compreensão das políticas e enfatizam a fluidez do poder e sua posse pelos diferentes agentes. A perspectiva pós-estruturalista aponta a importância de analisar o discurso das políticas (Mainardes et. al, 2011, pg 156).
}

Entende-se o processo como uma arena em que existe um processo permanente de disputas das apostas constantes nos discursos e nas idéias, reconhecendo a produção ativa de políticas em todos os espaços em todo momento. Essa perspectiva inspirou outras formulações, como a de Stephen Ball, que propõe que as políticas sejam analisadas como texto, como discurso, e como prática/efeitos.

A proposta de Ball batizada de "Policy Cycle Approach" ,melhor traduzido como "Abordagem do Ciclo de Políticas”, não estabelece relação de dependência, hierarquização ou relação temporal entre os movimentos ou planos de análise. 
Ball reconhece que existem muitos elementos constitutivos das políticas, muitos atores, forças e interesses e que estes estão em constante movimento, promovendo arranjos hiper-complexos; então, propõe que as políticas podem ser produzidas de forma diferente a partir desses contextos e movimentos.

Ball (2001) considera que uma política é texto mas também é discurso, e ela se configura ainda como ação, prática, processo. Nesse sentido, os textos podem ser considerados produtos de múltiplas influências e agendas, e a formulação deles envolve múltiplas negociações entre os diferentes atores, incluindo as intenções e negociações necessárias dentro do Estado.

A política como texto pode ser encontrada nos documentos oficiais que representam o acúmulo do processo de negociação e pactuação possível com linguagem adaptada ao conjunto de leitores. Por isso, ao analisarmos os documentos das políticas precisamos identificar as influências que não estão expressas nos textos, mas que ocorreram pelas disputas entre os atores, os interesses em jogo, os conceitos e idéias que disputaram seu espaço na formulação delas.

A política como discurso é expressa pela fala verbalizada, ela pode estar permeada, demonstrar o movimento de disputa de poder, de controle sobre o conhecimento ou a ideia expressa. Segundo Mainardes et. al (2011) a política como discurso estabelece limites para o pensamento e verbalização das ideias, já que se admite que somente algumas vozes censeguirão ser ouvidas e consideradas como legítimas e investidas de autoridade. Por isso, em algumas formulações esse é chamado como contexto de influência.

A política como processos e consequências, prática e efeitos, foi definida a partir da noção de movimento: a política não é estática e está em movimento constante, por isso ela pode ser expressa a partir da prática num contexto em que ocorrem disputas e conflitos e tudo isso interfere na sua própria produção. (Mattos e Baptista, 2011)

Ball sugere que as políticas produzem "regimes de verdade" a partir da compreensão que Foucault traz de verdade. Isso significa que diferentes atores em disputa o fazem a partir de diferentes regimes de verdade. Diferentes regimes de verdade que fabricam diferentes processos de subjetivação a partir 
das relações de poder que implementam. Conexão direta com a ideia de micropolítica de Foucault.

A disputa sobre a política não se esgota no movimento da sua formulação como texto e discurso pois ela está presente de forma permanente durante todo o movimento da sua produção, seja na formulação das idéias sobre a política, seja no seu processo de produção prático nos diferentes territórios e cotidianos. A disputa e a formulação estão presentes o tempo todo, elas também se expressam no espaço prático atravessadas pelo movimento ativo dos diferentes atores nos contextos e cenários. Assim, consideramos que a política existe quando em movimento, em ação, quando os diferentes atores operam seus interesses e forças, travam disputas e quando ela se estabelece a partir desses movimentos.

Outro conceito importante que emerge nesta discussão é o de poder, pois esses movimentos são operados a partir da defesa e disputa de projetos, ideias, apostas. Para Foucault (1979) o poder não existe em si; o que existem são relações de poder produzidas a partir de práticas sociais. 0 poder é exercido, funciona em rede e pode ser entendido como estratégia.

Um aspecto interessante trazido pelo autor é o deslocamento do exercício do poder do lócus do Estado, pois identifica que existem as relações de poder são produzidas em todos os lugares, dentro e fora do Estado. Isso expressa um deslocamentoem relação à teoria política tradicional que atribui ao Estado o monopólio de poder.

0 Estado se expressa também por meio de uma rede de micro-poderes que atravessa a estrutura social. Mas no plano da micropolítica muitas outras redes se misturam e atravessam na produção dos processos de subjetivação.

O poder está em toda parte; não porque englobe tudo, e sim porque provém de todos os lugares (FOUCAULT, 1976, p. 89). Assim, a rede de forças é percebida a partir de muitos vetores e, com isso, é possível perceber vetores de resistência, que exercem alguma força de neutralização ou de persuasão.

\footnotetext{
Temos que admitir que o poder produz saber (e não simplesmente favorecendo-o porque o serve, ou aplicando-o porque é útil); que poder e saber estnao diretamente implicados; que não há relação de poder sem a constituição correlata de um campo de saber, nem saber que não suponha e não constitua ao mesmo tempo relações de poder. Essas relações de "poder-saber" não devem ser analisadas a partir de um sujeito de conhecimento que seria ou não livre em relação aoa sistema de poder; mas é preciso considerar ao contrário
} 
que o sujeito que conhece, os objetos a conhecer e as modalidades de conhecimento são outros tantos efeitos dessas implicações fundamentais do poder-saber e de suas transformações históricas. Resumindo, não é a atividade do conhecimento que produziria um saber, útil ou arredio ao poder, mas o poder-saber, os processos e as lutas que o atravessam e o constituem, que determinam as formas e os campos possíveis do conhecimento (FOUCAULT, 1975, p. 30).

Essa reflexão sobre o conceito de poder facilita o pensamento sobre esse processo de produção ativa de políticas. Essa visão sobre as políticas permite compreender seu ciclo de produção a partir de diversos movimentos possibilitando uma compreensão mais ampliada desse processo complexo, buscando, assim, identificar os diversos atores, as forças envolvidas, os interesses que por vezes se cruzam e as diferentes consequências que acabam sendo produzidas a partir da prática, do fazer em ato que se dá no encontro entre o texto e o discurso e a realidade em que ela se concretiza. Esses movimentos, que se dão sem ordem definida e sem necessariamente relação de causalidade entre si, compõem o processo de produção da política de forma permanente, para além dos textos iniciais, possibilitando reformulações neles e nos discursos, assim como na ação.

Para Mainardes et. al. (2011), os três contextos (de influência, de produção de texto e da prática) apresentam suas arenas, seus lugares e grupos de interesse, suas disputas, cada um na sua particularidade. Sendo assim, é importante compreender os diferentes fatores que influenciam nos contextos de produção das políticas.

A análise do contexto considera os antecedentes e pressões produzidas e que influenciam a construção de uma dada política. As políticas produzem sujeitos a partir de processos de subjetivação, e estes, produzem textos, discursos e práticas. Nesse processo de produção, os diferentes atores disputam a definição do que é problema, sua explicação e a proposição das diferentes formas de enfrentá-los. Os interesses econômicos, sociais e políticos se expressam a partir dos atores em disputa. Assim, esses interesses que se configuram como vetores que operam nos diferentes planos e que interferem na produção das políticas e dos sujeitos que as produzem. (Ball e Mainardes, 2011)

Já na análise do texto, devemos olhar o conteúdo da política e das pressuposições que a fundamentam, mapeando os objetivos, os valores implícitos e explícitos, os 
fatos e fatores que não são considerados, bem como as idéias e conceitos explicitados. E tudo isso, influencia diretamente na prática em como os diferentes atores interpretam o texto e a executam. (Ball e Mainardes, 2011) Aqui entra a ideia de dispositivo. Tomamos as políticas como dispositivo, como propulsora de ações e ideias. $O$ conceito de Foucault propõe:

\footnotetext{
Um conjunto decididamente hterogêneo que engloba discursos, instituições, organizações arquitetônicas, decisões regulamentares, leis, medidas administrativas, enunciados científicos, proposicões filosóficas, morais, filantrópicas. Em suma, o ditto e o não ditto são os elementos do sispositivo. 0 dispositivo é a rede que se pode tecer entre esses elementos (Foucault, 2000, p. 244).
}

O autor também definiu que o dispositivo tem sempre uma função estratégica concreta e se inscreve sempre em uma relação de poder, por isso, esse conceito se conecta de forma direta com a noção e conceito de política que aqui estão sendo explorados. Política que se estabelece a partir das relações e que se produz nas disputas e cruzamentos desses vetores de forças e de interesses.

Foucault (2000) ainda sugere que o dispositivo traz em si uma episteme, que é um conceito aceito pela sociedade como científico sobre aquilo que nem sempre é científico. Diz ele que é um caso de episteme mais geral. Ou seja, é o sentido ligado a verdade das coisas. E pode ser expresso pela relação de força dos saberes.

O dispositivo está como uma linha que se produz nas conexões e que pode ser resultado da intersecção entre as relações de poder e as relações de saber. Agamben apud Chignola (2014) destaca que um dispositivo pode ser qualquer coisa que consiga capturar, orientar, determinar, interceptar, modelar, controlar e assegurar os gestos, os comportamentos, as opiniões e os discursos dos seres vivos. Assim, podemos compreender que o dispositivo opera como força e poder sobre algo.

Deleuze (1990) discute o dispositivo como um novelo composto por linhas diferentes emaranhadas e que trazem 3 elementos que podem ter relação entre si: saber, poder e subjetividade. Estas linhas (enunciação, força, subjetivação, ruptura) se tensionam, fraturam, afastam, aproximam, cruzam, abrindo a possibilidade de construção de diferentes planos analíticos.

A micropolítica, segundo Feuerwerker (2014), pode ser entendida como o processo de produção de subjetividades a partir das relações de poder. Ou seja, 
as relações produzem a micropolítica ${ }^{4}$, elas são atravessadas por interesses diversos que disputam espaço e isso produz política, a micropolítica. Podemos dizer que toda política se dá a partir de diferentes perspectivas.

Sendo assim, podemos compreender micropolítica como expressão dessas diferentes produções, jogos de poder, disputas de idéias e projetos, em que todos os atores estão ativamente em produção.

Compreender a perspectiva micropolítica nos ajuda a reconhecer que existem disputas e produção de política em todos os lugares e o tempo todo, assim, é possível construir dispositivos que possam interferir nessas disputas. Nessa perspectiva, também, é importante perceber os diferentes vetores que atravessam o processo de produção da política através da fala dos sujeitos e do modo como eles se relacionam. Desse modo, percebemos que as políticas produzem sujeitos, fabricam processos de subjetivação e, esses sujeitos produzem discursos e práticas.

Deleuze e Guattari (1996, p. 83) definem que “[...] tudo é político, mas toda política é ao mesmo tempo macropolítica e micropolítica". Afirmam ainda que

\begin{abstract}
(...) diz-se erroneamente (sobretudo no marxismo) que uma sociedade se define por suas contradições. Mas isso só é verdade em grande escala. Do ponto de vista da micropolítica, uma sociedade se define por suas linhas de fuga, que são moleculares. (...)o molar e o molecular não se distinguem somente pelo tamanho, escala ou dimensão, mas pela natureza do sistema de referência considerado (Deleuze e Guattari, 1996, p. 86-88).
\end{abstract}

Ao analisar a produção das políticas, então, é necessário investigar quais são os dispositivos propostos para que esta seja produzida nos diferentes contextos e os arranjos propostos para sua implementação. Reconhecendo que existem disputas permanentemente, tais dispositivos são fundamentais para sua produção, contudo, nem sempre eles são convergentes ou suficientes para a sua produção na prática.

\footnotetext{
${ }^{4}$ Alguns autores expressam uma separação dos planos de micro e macropolítica, localizam no plano macro as disputas que se dão na âmbito do Estado, construída num plano mais geral e estrutural do contexto; no plano micropolítico, admitem as relações que se estabelecem para produção dos processos de implementação das políticas. Admitem que também é produzida a partir de conflitos e disputas do cotidiano, num âmbito interno ou mesmo reducionista do ponto de vista dos sujeitos envolvidos. No entanto, a escolha conceitual aqui utilizada para definir o que é política, desconsidera tal dicotomia, e defende a idéia de que a política se constitui de diferentes formas em diferentes momentos e espaços dependendo do contexto onde estão localizados e é expressa pelas relações entre os sujeitos e isso se dá nos diversos planos.
} 
Os dispositivos das políticas podem favorecer rupturas, repetições, produção de regularidades, capturas ou estranhamentos, produção de singularidades e de invenção.

Se dialogarmos com o conceito de planejamento estratégico situacional (PES), amplamente difundido no campo da Saúde Coletiva com referência aos autores Carlos Matus e Mário Testa, podemos fazer uma certa analogia entre métodos de análise do processo de produção de políticas.

Se pensarmos que a formulação de projetos pode ser comparada a formulação de políticas, o processo de planejamento estratégico proposto demonstra alguns pontos em comum com o Ciclo de Análise de Políticas proposto por Ball. O PES, considerado somente como método e não como objeto, como o próprio Matus propõe, tem ação limitada na produção de políticas, no entanto, quando assumimos o conceito de que "todo mundo governa" e entendemos a etapa estratégica como a que de fato viabiliza o planejamento em si, talvez, possamos buscar essa similaridade com o conceito trazido por Ball.

Tal comparação é especialmente útil quando isolamos o contexto de producão de textos, que aqui foi analisado em um conjunto de políticas. A formulação dos projetos, dos planos, dos programas, das leis e das políticas, prevista pelo planejamento, de certa forma, tem alguma relação com a etapa de produção de texto aqui explorado a partir do conceito de Ball.

Para auxiliar nessa reflexão, Testa nos apresenta o conceito de política como uma proposta de distribuição de poder e de estratégia como a forma de implementação de uma política. A partir desse conceito de poder, desenvolveu-se uma tipologia para a saúde que separa o poder político, técnico e administrativo, a qual buscou mapear os atores, os interesses e os jogos de poder que estão produzindo as políticas de saúde. Esse olhar demonstra de forma mais clara a rede de poder que existe no sistema de saúde e na própria sociedade. (Testa apud Teixeira, 2010b)

Nessa perspectiva, o Postulado da Coerência, formulado pelo Testa, é uma possibilidade para análise dos processos de formulação e implementação de políticas de saúde. Ele estabelece 3 elementos que devem ser analisados considerando que estão em constante influência, são eles: propósitos (relações que produzem as propostas políticas e definem as apostas dos projetos), 
métodos (conceitos utilizados para concretizar os propósitos) e organização (estruturas e formas de organização dos processos de trabalho onde são produzidas as atividades governamentais). Analisando a coerência entre esses 3 elementos, pode-se indicar a maior ou menor potência de uma política, plano ou projeto para produzir os efeitos propostos. (Testa apud Teixeira, 2010b)

Tais formulações trazem elementos importantes para análise das políticas e fortalecem a escolha do referencial utilizado pois reforçam que existem mais elementos a serem considerados.

Do pensamento de Matus e Testa, uma outra idéia interessante é o reconhecimento de que todo mundo planeja, todo mundo governa e portanto, todo mundo faz e produz política. Esse conceito dialoga com o conceito da micropolítica.

A partir da perspectiva aqui adotada, reconhece-se que existem disputas em todo o processo de produção das políticas e não somente no momento de produção de textos. Portanto, o plano de produção de textos foi escolhido para analisar as mútuas influências entre as produções do sistema de saúde e da academia.

Atuando na produção de textos, a academia poderia atuar como produtora de política: formulando, interrogando, reafirmando, validando, avaliando. Essa foi uma das questões exploradas.

No âmbito do SUS, foi realizada uma breve análise sobre a produção das políticas selecionadas buscando mapear os conceitos produzidos ao longo do tempo.

O primeiro olhar sobre os documentos oficiais e institucionais encontrados como referências no SUS. Foram selecionadas portarias, leis, decretos, normas, e alguns documentos síntese publicados pelo próprio Ministério da Saúde.

\section{Um olhar direcionado aos textos oficiais das políticas}

Os documentos institucionais referentes a política de Atenção Básica estudados foram selecionados a partir do olhar dos arranjos organizativos da atenção à saúde e dos modos de organização do cuidado. Num primeiro olhar, foram encontrados e analisados 6 documentos oficiais classificados em: política, gestão, atenção e financimento. 
Linha do Tempo 1: Documentos Oficiais da Política de Atenção Básica

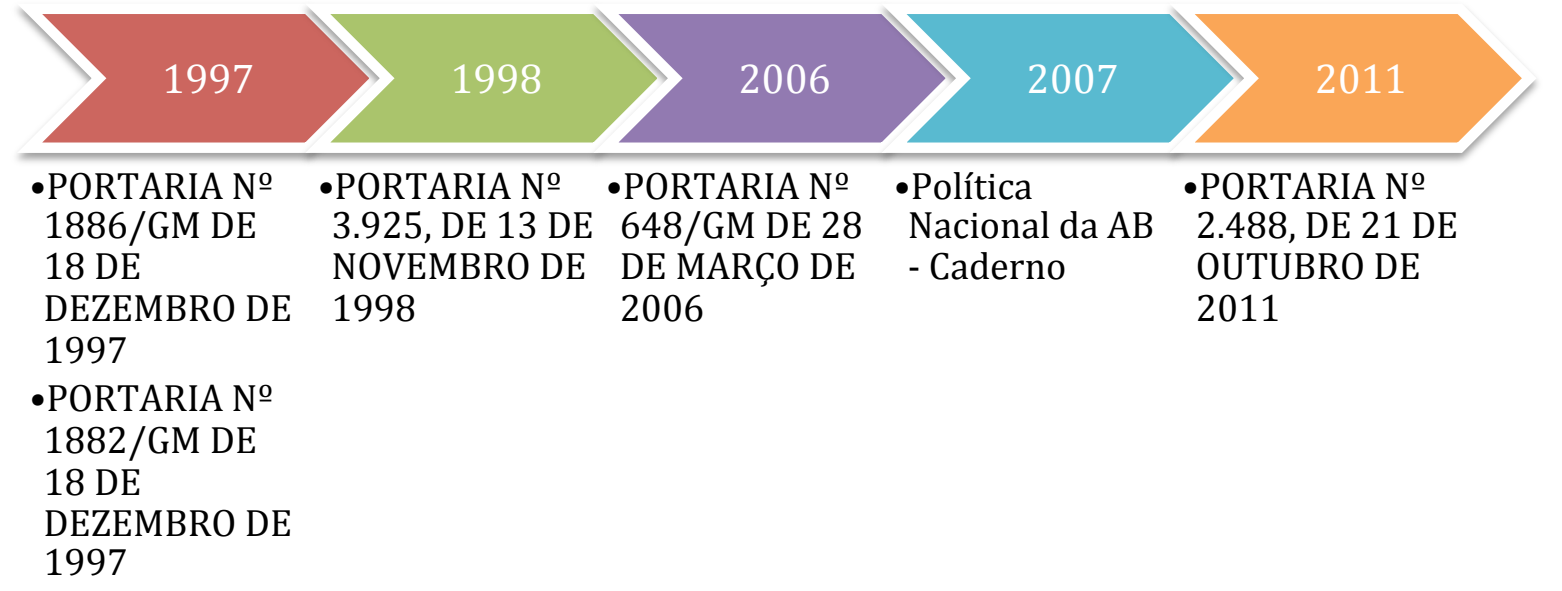

Cada um desses documentos foi analisado com o intuito de identificar quais as principais propostas contidas de cada um. Quais eram os conceitos disputados pela formulação política? Que dispositivos mobilizavam?

\section{PORTARIA № 1882/GM DE 18 DE DEZEMBRO DE 1997}

Objeto: Regulamenta o Piso da Atenção Básica - PAB e sua composição.

Principais Propostas: Reafirmar o Piso da Atenção Básica - PAB para o financiamento da atenção básica à saúde; Definir parte fixa e variável e fluxos de repasse fundo a fundo; Definir os diversos incentivos da atenção básica; Definir sistemas de informação para avaliação.

\section{PORTARIA № 1886/GM DE 18 DE DEZEMBRO DE 1997}

Objeto: Aprova as Normas e Diretrizes do Programa de Agentes Comunitários de Saúde e do Programa de Saúde da Família.

Principais Propostas: Definir as responsabilidades das esferas de gestão na execução e desenvolvimento do PACS e PSF; Definir as diretrizes operacionais dos programas; Definir os requisitos para adesão ao PSF.

\section{PORTARIA № 3.925, DE 13 DE NOVEMBRO DE 1998}

Objeto: Aprova o Manual para Organização da Atenção Básica no Sistema Único de Saúde.

Principais Propostas: Aprovar o Manual para Organização da Atenção Básica no Sistema Único de Saúde; Definir recursos orçamentários para a atenção básica e 
fluxos para transferência; Definir os indicadores de acompanhamento da atenção básica para o ano de 1999; Dar diretrizes para organização da atenção básica no SUS; Definir responsabilidades sanitárias para a atenção básica das diferentes esferas; Definir estratégias para cuidados específicos; Apresentar diretrizes operacionais para a política; Definir sistemas de informação; Definir processo de avaliação; Definir diretrizes para cadastramento e incorporação de serviços; Definir indicadores para acompanhamento da Atenção Básica.

\section{PORTARIA № 648/GM DE 28 DE MARÇO DE 2006}

Objeto: Aprova a Política Nacional de Atenção Básica, estabelecendo a revisão de diretrizes e normas para a organização da Atenção Básica para o Programa Saúde da Família (PSF) e o Programa Agentes Comunitários de Saúde (PACS).

Principais Propostas: Aprovar a Política Nacional de Atenção Básica; Definir os recursos orçamentários da política; Definir as responsabilidades das esferas; Definir a infra-estrutura, processo de trabalho das equipes e educação permanente das equipes; Definir as especificidades da Estratégia de Saúde da Família; (Re)Definir o financiamento da política (PAB fixo e variável); Definir as atribuições dos profissionais da equipe.

\section{Política Nacional da Atenção Básica - Caderno}

Objeto: Conjunto de portarias e documentos.

Principais Propostas: Reunir o conjunto de documentos oficiais sobre a política: Portaria no 648/GM de 28 de março de 2006, Portaria no 649/GM de 28 de março de 2006, Portaria nº 650/GM de 28 de março de 2006, Portaria no 822/GM de 17 de abril de 2006, Portaria no 2.133/GM de 11 de setembro de 2006, e Portaria no 1.624/GM de 10 de julho de 2007; Aprovar a Política Nacional de Atenção Básica; Definir os recursos orçamentários; Definir valores de financiamento para o ano de 2006, com vistas à estruturação de Unidades Básicas de Saúde para as equipes Saúde da Família, como parte da Política Nacional de Atenção Básica; Definir valores de financiamento do PAB fixo e variável mediante a revisão de diretrizes e normas para a organização da Atenção Básica, para a estratégia de Saúde da Família e para o Programa de Agentes Comunitários de Saúde, instituídos pela Política Nacional de Atenção 
Básica; Alterar critérios para definição de modalidades das ESF dispostos na Política Nacional de Atenção Básica; Definir o valor mínimo da parte fixa do Piso de Atenção Básica - PAB, para efeito do cálculo do montante de recursos a ser transferido do Fundo Nacional de Saúde aos municípios e ao Distrito Federal, e divulga os valores anuais/mensais da parte fixa do PAB, por município e Distrito Federal; Regulamentar, para o ano de 2007, a transferência dos incentivos financeiros referentes à Compensação de Especificidades Regionais - CER, componente da parte variável do Piso da Atenção Básica.

\section{PORTARIA № 2.488, DE 21 DE OUTUBRO DE 2011}

Objeto: Aprova a Política Nacional de Atenção Básica, estabelecendo a revisão de diretrizes e normas para a organização da Atenção Básica, para a Estratégia Saúde da Família (ESF) e o Programa de Agentes Comunitários de Saúde (PACS). Principais Propostas: Aprovar a Política Nacional de Atenção Básica; Definir os recursos orçamentários da política; Definir as diretrizes gerais e operacionais; Definir o papel da atenção básica na rede de atenção à saúde; Definir as responsabilidades das esferas; Apresentar e regulamentar as diretrizes de funcionamento dos componentes e das estratégias da política; Propor diretrizes para o processo de trabalho das equipes; Definir o financiamento e os recursos para os diversos componentes e estratégias.

No conjunto desses documentos oficiais analisados, percebemos que trazem questões sobre os seguintes temas: 1.5 .3 (economia/financiamento); 1.5 .4 (modelo de atenção); e 1.7 (Política de Atenção Básica). 0 exercício de análise com as categorias, destacou 3 categorias para cada política, sendo principal, secundária e terciária. Dessa forma, essas 3 categorias já citadas foram as de maior ocorrência, sendo que ainda foram utilizadas mais 2, são elas: 1.5 .13 (tecnologia e sistemas de informação) com 1 ocorrência; e 1.5.5 (gestão local).

Outros dois documentos foram analisados mas sua temática principal tratava de questões relacionadas com a política de regionalização e organização do SUS, contudo, trazem em seu conteúdo questões importantes sobre a definição do financiamento para as ações de atenção básica. Se olharmos novamente a linha 
do tempo, veremos que estes dois documentos devem ser considerados como relevantes para o entendimento dos desdobramentos da própria política

Linha do Tempo 2: Documentos Oficiais da Política de Atenção Básica

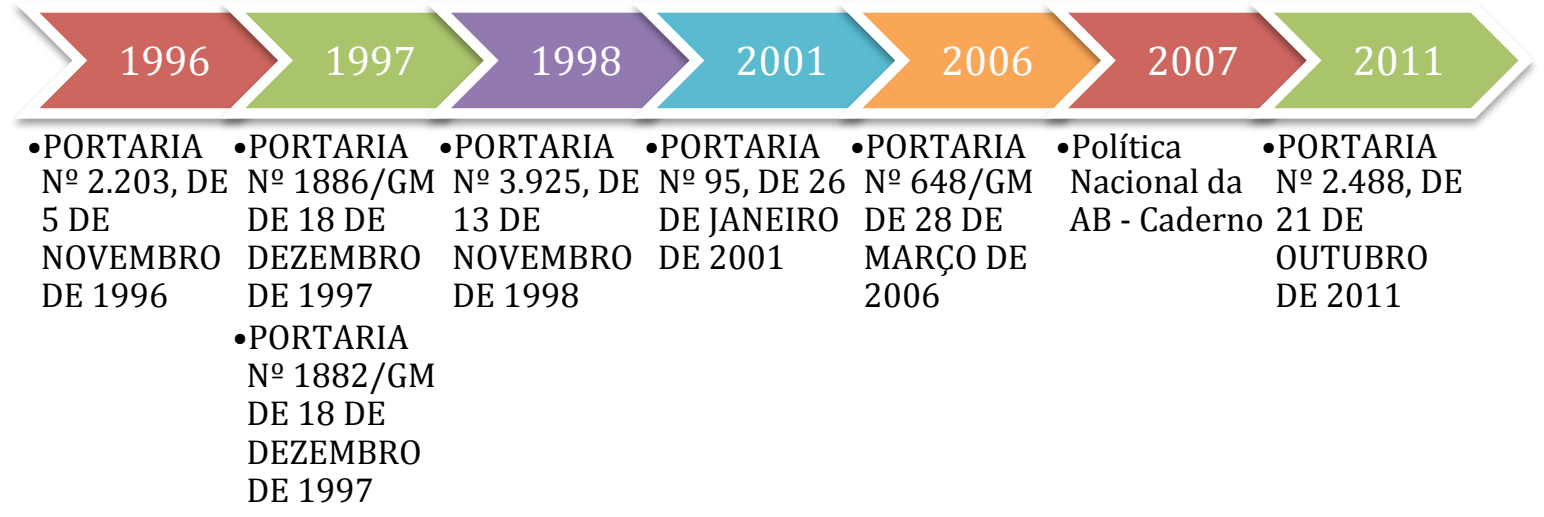

A Portaria № 2.203, de 5 de novembro de 1996, institui a NOB 1/96, cria o PAB, os incentivos pro PSF e pro PACS, assim como as condições de gestão dos municípios (gestão plena da atenção básica e gestão plena do sistema municipal), reconhecendo que os municípios devem, no mínimo, ser responsáveis pelo conjunto de ações de atenção básica no seu território.

Importante reconhecer que a NOB $1 / 96$, ao definir o financiamento, iniciou o porcesso de precarização dos vínculos de trabalho para as equipes do PSF considerando as diretrizes quanto a política de recursos humanos.

A Portaria № 95, de 26 de janeiro de 2001, que aprova a NOAS, instituiu a Gestão Plena da Atenção Básica Ampliada (GPAB-A) e o PAB fixo e variável como forma de financiamento da atenção básica, também volta a reconhecer a forma de habilitação dos municípios como gestão plena da atenção básica e gestão plena do sistema municipal.

Ambos documentos abordam o tema do financiamento e dos instrumentos de normatização do processo de descentralização, buscando definir as responsabilidades de gestão no sistema.

Os documentos institucionais selecionados sobre a política de regionalização e organização do SUS no âmbito da gestão para serem estudados consideraram o olhar para as suas estratégias de organização do conjunto da gestão do sistema 
de saúde. Foram localizados e analisados 9 documentos oficiais classificados em: política, gestão, atenção, participação e financiamento.

Linha do Tempo 3: Documentos Oficiais da Política de Regionalização e Organização do SUS

\begin{tabular}{|c|c|c|c|c|c|c|}
\hline \multicolumn{7}{|c|}{ • RESOLUÇÃO • PORTARIA } \\
\hline $\begin{array}{l}\text { DE } 19 \text { DE } \\
\text { SFTFMBRO }\end{array}$ & № 258, DE 07 & 545, DE 20 DE 2.203 , DE 5 D & E 373, DE $27 \mathrm{de}$ & $399 / \mathrm{GM}$ DE 22 & 27.508, DE 28 & 1.580, DE 19 \\
\hline $\begin{array}{l}\text { SETEMBRO } \\
\text { DE } 1990\end{array}$ & DE JANEIRO & MAIO DE 1993 NOVEMBRO & fevereiro de & $\mathrm{DE}$ & DE JUNHO DE & DE JULHO DE \\
\hline \multirow{2}{*}{\multicolumn{4}{|c|}{$\begin{array}{l}\text { - LEI № 8.142, } \\
\text { DE } 28 \text { DE }\end{array}$}} & DE 2006 & & \\
\hline & & & & - PORTARIA № & & \\
\hline \multirow{3}{*}{$\begin{array}{l}\text { DEZEMBRO } \\
\text { DE } 1990\end{array}$} & & & & 699, DE 30 DE & & \\
\hline & & & & MARÇO DE & & \\
\hline & & & & & & \\
\hline
\end{tabular}

Cada um desses documentos foi analisado com o intuito de identificar quais as principais propostas contidas de cada um. Buscou-se identificar quais eram os conceitos disputados pela formulação política,.

\section{LEI № 8.080, DE 19 DE SETEMBRO DE 1990}

Objeto: Dispõe sobre as condições para a promoção, proteção e recuperação da saúde, a organização e o funcionamento dos serviços correspondentes e dá outras providências.

Principais Propostas: Dispor sobre as condições para a promoção, proteção e recuperação da saúde, a organização e o funcionamento dos serviços; Definir a saúde como direito social; Definir que o SUS é constituído pelo conjunto de ações e serviços de saúde prestados por órgãos e instituições públicas federais, estaduais e municipais, da Administração direta e indireta e das fundações mantidas pelo Poder Público bem como pela iniciativa privada de forma complementar; Definir os objetivos do SUS; Definir os princípios e diretrizes do SUS; Definir a organização, gestão e organização do SUS; Definir as competências e atribuições das esferas no SUS; Criar o Subsistema de atenção à saúde indígena; Apresentar o subsistema de atendimento e internação domiciliar; Apresentar o subsistema de atenção ao parto; Definir diretrizes para assistência terapêutica e para a incorporação de tecnologia em saúde; Definir o funcionamento e participação dos serviços privados no SUS; Apresentar a política de recursos 
humanos na área da saúde; Definir o financiamento do SUS e seus desdobramentos na gestão.

\section{LEI № 8.142, DE 28 DE DEZEMBRO DE 1990}

Objeto: Dispõe sobre a participação da comunidade na gestão do Sistema Único de Saúde (SUS\} e sobre as transferências intergovernamentais de recursos financeiros na área da saúde e dá outras providências.

Principais Propostas: Instituir a participação popular no SUS a partir das Conferências de Saúde e Conselhos de Saúde; Definir a alocação dos recursos financeiros do FNS mediante critérios e requisitos.

\section{RESOLUÇÃO № 258, DE 07 DE JANEIRO DE 1991}

Objeto: Aprovar a Norma Operacional Básica/SUS no 01/91, constante do Anexo I da presente Resolução, que trata da nova política de financiamento do Sistema Único de Saúde - SUS para 1991

Principais Propostas: Definir os mecanismos de financiamento das atividades ambulatoriais; Criar e estruturar os instrumentos de acompanhamento, controle e avaliação da execução das atividades do SUS (Conselhos de Saúde, Fundo de Saúde, Consórcios Administrativos, Relatórios de Gestão); Estabelecer programação, planos de aplicação, e processos de prestação de contas dos Fundos; Instituir os processos de controle a avaliação no SUS sob coordenação do MS.

\section{PORTARIA № 545, DE 20 DE MAIO DE 1993}

Objeto: Estabelece normas e procedimentos reguladores do processo de descentralização da gestão das ações e serviços de saúde, através da Norma Operacional Básica - SUS 01/93.

Principais Propostas: Aprovar a Norma Operacional Básica - SUS 01/93, constantes do anexo único desta portaria, que regulamenta o processo de descentralização da gestão dos serviços e ações no âmbito do Sistema Único de Saúde e estabelece os mecanismos de financiamento das ações saúde, em particular da assistência hospitalar e ambulatorial e diretrizes para os investimentos no setor; Definir regras de financiamento no SUS; Definir as 
condições de gestão (Condição de gestão incipiente, Condição de gestão parcial, Condição de gestão semi-plena); Definir o processo de gerenciamento da descentralização a partir do funcionamento da Comissão Intergestores Tripartite (CIT) e do Conselho Nacional de Saúde (CNS), em âmbito nacional; e do funcionamento da Comissão Intergestores Bipartite (CIB) e do Conselho Estadual de Saúde, em âmbito estadual.

\section{PORTARIA № 2.203, DE 5 DE NOVEMBRO DE 1996}

Objeto: Aprovar, nos termos do texto anexo a esta Portaria, a NOB 1/96, a qual redefine o modelo de gestão do Sistema Único de Saúde, constituindo, por conseguinte, instrumento imprescindível à viabilização da atenção integral à saúde da população e ao disciplinamento das relações entre as três esferas de gestão do Sistema.

Principais Propostas: Redefinir o modelo de gestão do SUS; Definir campos da atenção à saúde; Definir normas de organização do sistema de saúde municipal e para a relação entre os sistemas municipais; Definir o papel do gestor estadual e do gestor federal; Instituir os espaços de articulação entre os gestores; Definir bases para um novo modelos de atenção à saúde; Definir as regras de financiamento do SUS; Instituir a PPI; Instituir o PAB, os incentivos pro PSF e pro PACS, o FAE, o TFAM, o TFAE, e outras formas de custeio e fnanciamento; Definir as condições de gestão dos estados e municípios (gestão plena da atenção básica e gestão plena do sistema municipal ou gestão avançada do sistema estadual e gestão plena do sistema estadual).

\section{Portaria no 373, DE 27 de fevereiro de 2002}

Objeto: Aprovar a Norma Operacional da Assistência à Saúde - NOAS-SUS 01/2002 que amplia as responsabilidades dos municípios na Atenção Básica; estabelece o processo de regionalização como estratégia de hierarquização dos serviços de saúde e de busca de maior eqüidade; cria mecanismos para o fortalecimento da capacidade de gestão do Sistema Único de Saúde e procede à atualização dos critérios de habilitação de estados e municípios.

Principais Propostas: Estabelecer o processo de regionalização; Instituir o PDR; Instituir a Gestão Plena da Atenção Básica Ampliada (GPAB-A), como uma das 
condições de gestão dos sistemas municipais de saúde (PAB fixo e variável); Definir a PPI como instrumento político-financeiro para garantia do acesso aos serviços de média e alta complexidade; Instituir a CNRAC; Instituir processo de controle, regulação e avaliação; Instituir normas de habilitação dos estados e municípios como gestão plena da atenção básica e gestão plena do sistema municipal e gestão avançada do sistema estadual e gestão plena do sistema estadual; Regulamentar a relação com os hospitais e prestadores de serviço.

\section{PORTARIA № 399/GM DE 22 DE FEVEREIRO DE 2006}

Objeto: Divulga o Pacto pela Saúde 2006 - Consolidação do SUS e aprova as Diretrizes Operacionais do Referido Pacto.

Principais Propostas: Divulgar o Pacto; Aprovar as Diretrizes Operacionais do Pacto pela Saúde em 2006; Definir diretrizes de organização do SUS no âmbito da atenção, gestão e participação, definindo indicadores de pactuação, monitoramento e avaliação; Definir responsabilidades das esferas de gestão na regionalização e organização do sistema; Redefinir blocos e formas de repasse do financiamento no SUS.

\section{PORTARIA № 699, DE 30 DE MARÇO DE 2006}

Objeto: Regulamenta as Diretrizes Operacionais dos Pactos Pela Vida e de Gestão. Principais Propostas: Regulamentar a implementação das Diretrizes Operacionais dos Pactos Pela Vida e de Gestão e seus desdobramentos para o processo de gestão do SUS bem como a transição e o monitoramento dos Pactos, unificando os processos de pactuação de indicadores e metas; Estabelecer as responsabilidades sanitárias dos gestores; Definir os instrumentos de pactuação entre os gestores; Estabelecer normas para a definição, alteração e suspensão dos valores do Limite Financeiro Global do Município, Estado e Distrito Federal; Explicitar a participação financeira dos gestores na execução das ações e serviços de saúde. 


\section{DECRETO № 7.508, DE 28 DE JUNHO DE 2011}

Objeto: Regulamenta a Lei no 8.080, de 19 de setembro de 1990, para dispor sobre a organização do Sistema Único de Saúde - SUS, o planejamento da saúde, a assistência à saúde e a articulação interfederativa, e dá outras providências.

Principais Propostas: Regulamentar a organização e funcionamento do SUS; Instituir as regiões de saúde e sua forma de organização das ações e serviços de saúde; Regulamentar o planejamento da saúde; Definir os instrumentos de planejamento e organização do SUS; Regulamentar as relações interfederativas no SUS; Instituir o COAP como instrumento de pactuação entre gestores; Definir portas de entrada e formas de organização das redes de atenção.

\section{PORTARIA № 1.580, DE 19 DE JULHO DE 2012}

Objeto: Afasta a exigência de adesão ao Pacto pela Saúde ou assinatura do Termo de Compromisso de Gestão, de que trata a Portaria no 399/GM/MS, de 22 de fevereiro de 2006, para fins de repasse de recursos financeiros pelo Ministério da Saúde a Estados, Distrito Federal e Municípios e revoga Portarias.

Principais Propostas: Definir que o repasse federal do SUS ocorrerá independente da adesão ao Pacto ou assinatura do TCG.

Esses documentos oficiais, quando categorizados pelas categorias utilizadas para análise das produções das teses, dissertações e artigos publicados, revelam 5 como categorias temática principais. São elas: 3.11 (Aspectos políticos e operativos do sistema de saúde); 3.1 (Regionalização); 3.9 .3 (Decreto); 3.7 (Financiamento); e 3.9.2 (Pacto).

0 exercício de análise com as categorias, destacou 3 categorias para cada política, sendo principal, secundária e terciária. Dessa forma, essas 5 categorias já citadas foram as de maior ocorrência, sendo que ainda foram utilizadas mais 6, são elas: 3.2 (Descentralização) com 4 ocorrências; 3.8 (Planejamento) com 2 ocorrências; 3.5.2 (Articulação Intergestores) com 2 ocorrências; 3.5 .3 (Espaços colegiados), 3.9.1 (Normas Operacionais) e 1.5.3 (Economia/Financiamento da Política de Atenção Básica). 
Os documentos institucionais sobre a política de Educação na Saúde selecionados e estudados partiram de uma perspectiva sobre a educação permanente em saúde como estratégia de gestão e qualificação da organização do sistema de saúde tanto no âmbito da gestão como do cuidado. Foram selecionados 5 documentos oficiais classificados em: política, gestão, educação e financiamento.

Linha do Tempo 4: Documentos Oficiais da Política de Educação na Saúde

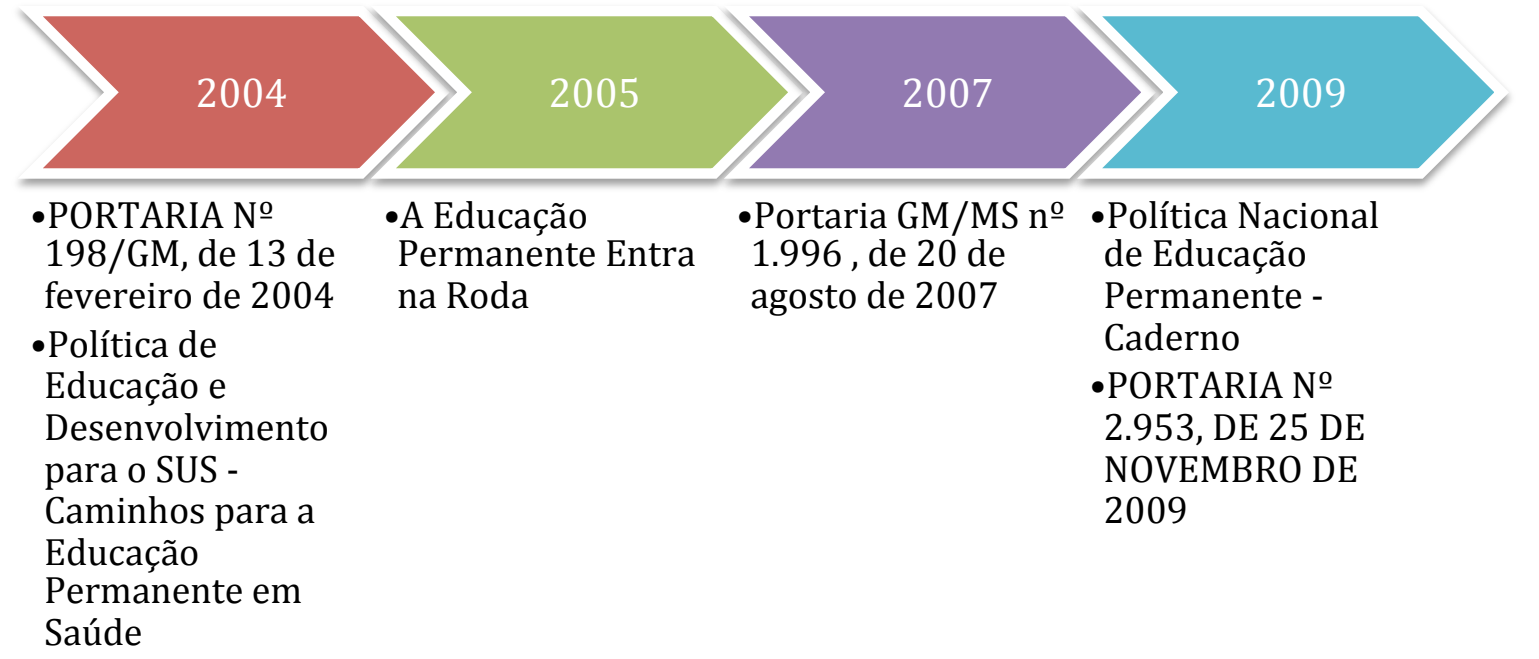

Cada um desses documentos foi analisado com o intuito de identificar quais as principais propostas contidas de cada um. Da mesma forma que com as outras duas políticas, aqui esperava-se identificar quais eram os conceitos disputados pela formulação política, quais os dispositivos propostos etc.

\section{Política de Educação e Desenvolvimento para o SUS - Caminhos para a Educação Permanente em Saúde}

Objeto: Caderno de Apoio à Política. Após aprovação e pactuação desta política, o Deges deu início ao processo de constituição dos Pólos de Educação Permanente em Saúde e à aprovação de projetos.

Principais Propostas: Apresentar de forma ampliada a Política Nacional de Educação Permanente; Definir diretrizes operacionais para o funcionamento dos Pólos de Educação Permanente em Saúde no SUS; Apresentar o conjunto de ações e estratégias propostas para o apoio e a dinamização da constituição da educação permanente em saúde e o fortalecimento do trabalho de formação e 
desenvolvimento em saúde; Apresentar o conjunto da legislação que subsidia essa política.

\section{PORTARIA № 198/GM Em 13 de fevereiro de 2004}

Objeto: Institui a Política Nacional de Educação Permanente em Saúde como estratégia do Sistema Único de Saúde para a formação e o desenvolvimento de trabalhadores para o setor e dá outras providências.

Principais Propostas: Instituir a Política Nacional de Educação Permanente em Saúde como estratégia do Sistema Único de Saúde para a formação e o desenvolvimento de trabalhadores para o setor; Conformar os Pólos de Educação Permanente em Saúde para o SUS e diretrizes para seus funcionamentos; Definir orçamento para viabilizar a política; Instituir processo e responsáveis pelo acompanhamento da política.

\section{A Educação Permanente Entra na Roda - encarte institucional}

Objeto: Caderno sobre conceitos e caminhos a percorrer, apoio à política.

Principais Propostas: Apresentar a importância da política de formação e desenvolvimento para o SUS, o que já foi feito e os desafios ainda existentes; Apresentar as propostas e estratégias da política; Apresentar reflexões sobre o tema da educação permanente e sua potencialidade para o SUS; Apresentar os Pólos de Educação Permanente em Saúde e como estnao sendo implementados no país.

\section{Portaria GM/MS no 1.996 , de 20 de agosto de 2007}

Objeto: Dispõe sobre as diretrizes para a implementação da Política Nacional de Educação Permanente em Saúde e dá outras providências.

Principais Propostas: Definir novas diretrizes e estratégias para a implementação da Política Nacional de Educação Permanente em Saúde; Definir estratégias de execução da política; Vincular os CGR como espaços de definição do planejamento da política em nível regional; Instituir as CIES e seu funcionamento; Definir os espaços de deliberação da agenda da educação permanente; Definir os recursos financeiros que financiarão a política nas diferentes esferas; Definir o papel do Ministério da Saúde na indução e apoio à 
política; Reativar a Comissão Nacional de Acompanhamento da Política Nacional de Educação Permanente em Saúde.

\section{Política Nacional de Educação Permanente - Caderno}

Objeto: Conjunto de portarias e documentos.

Principais Propostas: Divulgar a Portaria GM/MS nº 1.996, de 20 de agosto de 2007 que Dispõe sobre as diretrizes para a implementação da Política Nacional de Educação Permanente em Saúde e dá outras providências; Instituir e definir diretrizes operacionais para o funcionamento das CIES; Definir a alocação financeira da política; Definir diretrizes e orientacões para a formação dos trabalhadores em nível técnico; Definir diretrizes para as responsabilidades do Pacto referentes à educação; Apresentar estudo sobre o tema dos recursos humanos previamente desenvolvido.

\section{PORTARIA № 2.953, DE 25 DE NOVEMBRO DE 2009}

Objeto: Define recursos financeiros do Ministério da Saúde para a Política Nacional de Educação Permanente em Saúde, e dá outras providências.

Principais Propostas: Definir novos recursos financeiros do Ministério da Saúde para a implementação da Política Nacional de Educação Permanente em Saúde, no exercício de 2009; vincular o exercício financeiro da política ao Plano Estadual de Educação Permanente em Saúde; estabelecer diretrizes, critérios e fluxos para a anealise do Plano considerando em suas açõesa articulação com Programas estratégicos do SGTES: Pró-Saúde, PET-Saúde, Telessaúde, Residência Médica em Medicina de Família e Comunidade, Residência Multiprofissional em Saúde, Formação Profissional Técnica de Nível Médio, Programa de Capacitação Gerencial, PROGESUS, dentre outras ações.

No conjunto desses documentos oficiais analisados, quando categorizados pelas mesmas sub-categorias utilizadas para análise das produções das teses, dissertações e artigos publicados, encontramos a ocorrência de 1 delas como categoria temática principal: 2.8.2 (Política de EPS). 0 exercício de análise com as categorias, destacou 3 categorias para cada política, sendo principal, secundária e terciária. Dessa forma, essa categoria já citada obteve ocorrência em todos os 
documentos analisados, sendo que ainda foram utilizadas mais 3, são elas: 2.8.1 (Pólos e outros espaços colegiados) com 5 ocorrências; 2.8 .10 (estratégia de gestão) com 4 ocorrências; e 2.8.9 (Análise da política).

Ainda foram explorados outros documentos para ajudar a compreender esses documentos. No entanto, é importante registrar que se compreende que as políticas expressas nos textos têm papel de dispositivo e propõem dispositivos para a prática e para a implementação das estratégias e das diferentes operações por ela formuladas.

Mas os diferentes atores posicionam-se, fazem uso, disputam sentidos e produções no cotidiano da gestão e do trabalho.

Por outro lado, também é importante reconhecer os atravessamentos a partir da biopolítica ou dos saberes e poderes biomédicos instituídos. E interrogar a potência das políticas e de seus dispositivos no encontro com esse instituído No próximo capítulo, vamos explorar um pouco mais sobre as políticas produzidas e aqui analisadas com o intuito de que seja possível identificar essas possíveis influências. 
Sobre os encontros: algumas reflexões sobre as políticas e seu papel dispositivo no SUS

Com o objetivo de mapear as linhas de produção dos conceitos encontrados nas políticas, terminei narrando os processos históricos de produção das três políticas selecionadas, destacando os atores, os contextos, as apostas, os interesses e jogos de poder em questão quando houve possibilidade para tal análise.

Nesse exercício busquei destacar conceitos em disputa na produção das ações e práticas que dão vida a política e seu processo de permanente produção e reprodução.

\section{Um olhar direcionado aos textos produzidos sobre a Política de Atenção} Básica

A atenção básica vinha sendo produzida de diferentes formas, mesmo antes da existência do SUS, nos municípios brasileiros. Já nos anos 20 , com a criação dos primeiros centros de saúde em São Paulo, uma certa ideia de atenção básica, fortemente focada nas ações materno-infantis, veio sendo produzida.

A década de 70 destaca-se como momento de experimentações municipais e de expansão de algumas redes, como no estado de São Paulo. Municípios que desenvolveram experiências interessantes: Niterói, Londrina, Campinas, Montes Claros, entre outros. Em geral, os gestores desses municípios eram contrários ao regime militar e se preocupavam em formular novas formas de organizar os serviços de saúde, dando os primeiros passos no que imaginavam ser a constituição de um sistema de saúde.

Também é importante situar que nesse momento vivíamos um processo de estruturação das ações de saúde pública, fomentadas e coordenadas pelo Ministério da Saúde. Mas a lógica da saúde pública não dialogava com a da assistência médica. Ministério da Saúde e Ministerio da Previdência e Assistência Social em ações distintas, fabricavam distintos arranjos. 
Enfim, era um período complexo e os movimentos sociais estavam se organizando e se fortalecendo para pressionar pelo fim da ditadura e também pela construção de um sistema de saúde brasileiro.

Também na década de 70, começou a ser organizando um movimento sanitário brasileiro. Esse movimento já foi comentado quando discutimos a produção da saúde coletiva brasileira. Vale destacar que a nascente saúde coletiva/movimento sanitário emplacou várias formulações e conceitos no movimento da constituinte e depois da organização do SUS.

Nesse período foram propostos programas que tiveram um impacto político importante, como foi o caso do Programa Nacional de Alimentação e Nutrição (PRONAM) e Programa de Interiorização das Ações de Saúde e Saneamento (PIASS). Tratavam-se de programas voltados, na teoria, para a atução preventiva, na tentativa de buscar eliminar as condições causadoras das enfermidades. 0 PRONAM estava sendo lançado numa segunda tentativa e, desta vez, não mais centrava suas ações sobre a industrialização de alimentos, mas sim tinha em vista a compra de insumos e o estímulo à oferta de alimentos básicos. Já o PIASS propunha-se a implementar e operar uma estrutura básica de saúde e saneamento.

Em 1977, os atendimentos de urgência passaram ser realizados de forma ampla, sem restrições ao segmento previdenciário, e isso trouxe consequências financeiras para o setor exigindo mais eficiência enconômica. Em resposta, foram criados o Programa Nacional de Serviços Básicos de Saúde (Prev-Saúde), que teve inúmeras versões mas nunca conseguiu ser, de fato, implementado, e o Conselho Consultivo de Administração da Saúde Previdenciária (Conasp) criado pelo Decreto $\mathrm{n}^{\circ} 86.329$, de 02 de setembro de 1981. É interessante registrar que o Conasp chegou a propor que houvesse uma descentralização do sistema de assistência médica criando uma única porta de entrada a partir do aproveitamento da rede de serviços ${ }^{5}$ do Inamps e somente havendo complementariedade de serviços privados onde houvesse necessidade. Nesse

\footnotetext{
${ }^{5}$ A idéia da municipalização e descentralização das ações é de diretriz para organização e produção das ações de saúde nas diversas regiões, estados e municípios. A partir da formulação do Conasp, buscou-se descentralizar o sistema de assitência médica a partir da rede de serviços do INAMPS, especialmente para ampliar o acesso, especialmente para urgências.
} 
período, a municipalização passou a ser entendida como estratégica. (Merhy \& Queiroz, 1993)

Nesse mesmo ano de 1977, vários países do mundo paraticiparam da 30ª reunião da Assembléia Mundial da Saúde, onde os governantes se comprometeram em melhorar o nível mundial de saúde até os anos 2000. Em 1978, em Alma Ata, a Conferência Internacional sobre Atenção Primária à Saúde (APS), promovida pela OMS, afirmou que a APS 6 é a estratégia para conseguirmos saúde para todos no ano 2000. A partir desse episódio, a OMS começou a defender a APS, e, o Banco Mundial, a financiar projetos e políticas voltadas para seu desenvolvimento. Esses fatos marcaram e ainda marcam a atenção básica desenvolvida em muitos países incluindo o Brasil. Tanto a OMS como o Banco Mundial são atores relevantes e desde então tem sido influentes na definição das políticas de saúde de muitos países, especialmente os países pobres ou em desenvolvimento.

Nesse momento, de intensa luta pela redemocratização do país, já existiam espaços de formulação e debate sobre um novo campo de conhecimento na saúde, já havia movimentos politicos em torno do direito à saúde, também existia uma importante crise econômico-financeira da Previdência Social. (Giovanella \& Mendonça, 2008)

Em 1983, foi criado o Programa de Ações Integradas de Saúde (PAIS), que visava universalizar a assistência médica com financiamento baseado na produção para todos os municípios. Mais tarde, em 1985, o PAIS vira as AIS (Ações Integradas de Saúde), resultado de um movimento de integração da saúde com a previdência e que evidencia a produção de um discurso e práticas que incluiam conceitos como a descentralização e a universalização ${ }^{7}$. As AIS possibilitaram a construção de unidades de saúde em boa parte dos municípios brasileiros. Tudo isso acontecia em pleno movimento de mudança do regime politico do país, com pressões de vários segmentos sociais e políticos.

\footnotetext{
${ }^{6}$ A APS foi considerada uma estratégia potente para ampliar o acesso e a promoção da saúde para todos por meio de serviços de atenção primária. A partir de Alma-Ata e da atuação da OMS e do Banco Mundial, foram apoiados e financiados projetos em diversos países.

${ }^{7}$ Proposta de amplo acesso aos serviços de assistência médica. A partir do PAIS, foram financiadas ações de assistência médica para todos os municípios.
} 
As AIS, no SUDS, em 1987, fizeram o deslocamento das responsabilidades da saúde para os Estados; foram ações essencialmente descentralizadoras ${ }^{8} \mathrm{e}$ buscavam universalizar o acesso aos serviços básicos de saúde. Portanto, nesse momento já ocorriam ações concretas a partir de conceitos que depois foram formalizadas como princípios e diretrizes do sistema de saúde. (Giovanella \& Mendonça, 2008)

Segundo Merhy et. al. (2004), a política de saúde no Brasil, nos anos 80, foi produzida de forma paradoxal, pois seus instrumentos jurídico-legais apresentavam um certo texto e discurso baseados na concepção universalizante do sistema, contudo, as práticas sociais eram pautadas na exclusão e pelo acesso seletivo aos serviços.

Nesse contexto, foram feitas diversas experimentações de arranjos organizativos para a construção do SUS, em que alguns municípios e o Ministério da Saúde assumiram um papel protagonista.

Na Constituição Federal de 88, aprovados o direito à saúde, a criação do SUS e também o reconhecimento do setor privado, desde que complementar ao SUS. Foi afirmada a idéia-conceito da pirâmide ${ }^{9}$ como modelo de atenção, inspirada no Relatório Dawson. Apesar das críticas ao modelo medico-hegemônico lideradas pelo movimento sanitário, a fomulação da pirâmide na prática institui/reforça a hierarquia entre diferentes práticas de saúde, colocando a atenção hospitalar no topo e a atenção básica na base. Falava-se de níveis de complexidade pensando na gravidade clínica dos processos de adoecimento e na incorporação de equipamentos e saberes especializados, sem levar em conta a complexidade politico-social dos problemas de saúde/ sofrimentos vivenciados nos territórios.

Essa perspectiva de organização do sistema adotada no Brasil já existia em outros sistemas universais, como na Inglaterra e no Canadá, em que a garantia do

\footnotetext{
${ }^{8} \mathrm{~A}$ idéia de descentralização dos serviços básicos de saúde pode ser definida como a desconcentração das responsabilidades pela oferta de serviços básicos de saúde. A partir das AIS, houve apoio para construção de unidades de saúde, e descentralização das responsabilidades para os Estados, apesar de estando ainda amarrado o financiamento a partir do registro da produção.

${ }^{9}$ Modo de organização e articulação dos serviços de saúde considerando os diferentes níveis de complexidade de cuidado e incremento de tecnologias assistenciais. Inspirado no Relatório Dawson, os serviços de saúde devem ser organizados a partir de uma lógica hierarquizada para o acesso, considerando que a base seria a atenção básica como porta de entrada do sistema. Financiamento racionalizado e acesso regulado.
} 
direito à saúde não estava articulada com a necessidade de superação das desigualdades sociais, nem com propostas políticas "emancipatórias" e antihegemônicas.

Ou seja, o modelo da pirâmide responde a certos princípios, mas é tenso em relação a outros, presentes nas aspirações da reforma sanitaria brasileira. Ele também supõe uma certa racionalidade economico-financeiro no desenho da rede de serviços, supondo uma certa economia de escala para efetivação racional de serviços especializados.

No Canadá essa racionalidade não funciona quando se trata de estabelecer serviços e fixar profissionais no norte gelado e vazio do país. No Brasil, então, que convive com fortíssimas desigualdades socias intra e interregionais e que nos grandes centros urbanos enfrenta a concorrência da saúde suplementar, o desenho da pirâmide fica completamente esgarçado na prática.

Outros elementos, embora questionados, permanecem sustentados a partir da força de certos vetores. Por exemplo, a contratação de serviços por procedimentos e depois a remuneração de serviços por procedimentos, por exemplo, foram quebradas no financiamento da atenção básica por meio do per capita, mas persistem no financiamento à "media e alta complexidade", designação que também fabrica a atenção básica num lugar de inferioridade, simplicidade e subordinação em relação aos demais arranjos assistenciais.

Nesse momento de construção inicial do SUS, havia diferentes interesses em disputa no âmbito dos serviços, pois, durante a ditadura, um importante ator foi fabricado a partir do financiamento estatal: o setor privado de saúde, representado nesse momento sobretudo pelos donos de hospitais privados e de operadoras de saúde.

Também havia os interesses das diferentes corporações, sobretudo dos médicos, em disputa por um lugar de boa remuneração e autonomia na produção de seu trabalho.

E, ainda, havia os interesses do capital, de todo o complexo medico-hospitalar, interessados na ampliação do Sistema, desde que sob a lógica do modelo medicohegemônico. 
Como já mencionado, OMS e Banco Mundial também atuavam em prol de uma expansão da rede básica, focada em ações educativas, de prevenção, de promoção e na vigilância em saúde ${ }^{10}$.

Portanto havia disputa de projetos em torno da atenção básica: que atenção básica, com que apostas, articulada de que modo ao restante do Sistema, fortalecendo que modelo assistencial, movida por que trabalhadores e em cima de qual agenda? No interior do prórpio movimento sanitário havia divergências em relação a essas questões.

O país se encontrava num cenário complexo, reestruturando-se após um longo regime militar e de uma forte crise financeira, tensionado pelo crescente capitalism financeirizado, desafiado para assegurar o conjunto de políticas sociais conquistadas constitucionalmente.

Na saúde, o cenário era marcado por disputas importantes, decisivas para determinar qual a concepção de saúde iria ser construída e desenvolvida no país (direito/consumo; universalidade/focalização; medicalização/defesa da vida; biologismo/integralidade; participação/paternalismo; centralidade no medico/centralidade na equipe; cuidado/subordinação etc, pares binários representativos de planos de disputa intensivos).

Silva Junior (2006) nos apresenta o modelo dos Silo de formulação original da OPS, implementado em em vários lugares, incluindo o município de Salvador, que propunha a construção de sistemas locais de saúde por meio de distritos sanitários, que implicariam a descentralização das ações e das decisões sobre os problemas locais, ampliando o acesso às ações de saúde. A epidemiologia ${ }^{11}$ era utilizada como ferramenta central para identificar e analisar os problemas de saúde do território e para construir propostas para seu enfrentamento. Dessa experiência, é importante resgatar algumas idéias como a noção de planejamento ${ }^{12}$, de regionalização, de território, de programação e de vigilância.

\footnotetext{
${ }^{10}$ Lógica de organização de ações de saúde voltadas para proteção de condições de risco e vulnerabilidade à saúde. Pautada pelo controle, fiscalização e proteção à saúde.

${ }^{11}$ Conjunto de conhecimentos e tecnologias para estudo das doenças e das condições de adoecimento. A lógica epidemiológica organiza as ações e serviços a partir desses estudos.

${ }^{12}$ Metodologia e ferramenta utilizada para organizar as ações de saúde a partir do processo de diagnóstico, análise situacional e proposição de ações de saúde que respondam aos problemas identificados. Idéia presente desde o modelo dos SILOS.
} 
Essas ideias, de alguma forma experimentadas nos territórios, são essenciais nos debates do movimento sanitário.

Merhy et. al. (2004) chama a atenção para a perspectiva de democratização da sociedade trazida pelos SILOS onde foram criados mecanismos de participação social desde o processo de planejamento, centrado na proposta de intervenção sobre os problemas identificados de acordo com prioridades e visando impacto sobre indicadores. Assim, considera que existe uma relação entre o que o cotidiano produz e o que se expressa nos corpos. Compreende a ideia de território-processo, reconhecendo que por meio de um olhar ampliado para o território ${ }^{13}$ podem ser identificados os problemas de saúde a serem enfrentados. Tal modelo, muito influenciado pelo planejamento, desenvolve ações de vigilância em saúde como mecanismo de organização dos processos de trabalho já que se baseia nos problemas, sobre os quais produz intervenção.

As diferentes experimentações em torno do SILOS foram interessantes para trazer concretude as ações que utilizavam o planejamento estratégico e que criavam espaços participativos dentro dos serviços e dos sistemas de saúde. Teve dificuldades de sustentabilidade a longo prazo, mas foi o precursor dos distritos sanitários depois de implantados em muitos municípios.

As Cidades Saudáveis compuseram uma proposta nascida em Toronto, no Canadá, em 1984, que trazia na sua concepção a idéia da promoção da saúde. A lógica da promoção ${ }^{14}$ enfatizava a melhoria da qualidade de vida num conceito mais ampliado. No Brasil, foi muito influenciada pela experiência dos SILOS e trazia em sua proposta a perspectiva de participação e de desenvolvimento de ações intersetoriais para reorientação dos serviços de saúde. (Merhy et. al., 2004)

O modelo de atenção pautado pela promoção da saúde, influenciado pela Carta de Ottawa, propõe cinco campos centrais de ação: Elaboração e implementação de políticas públicas saudáveis, Criação de ambientes favoráveis à saúde, Reforço

\footnotetext{
${ }^{13} \mathrm{O}$ conceito de território aqui abordado considera que ele é o locus de atuação para produção da assitência, nele são mapeados riscos e indicadores epidemiológicos que possam apontar tendências sobre situações de adoecimento, e, a partir desse locus deveriam ser planejadas as ações. Esse conceito esteve presente desde a produção do modelo de SILOS.

${ }^{14}$ Mecanismo de produção de ações que visem melhores condições e qualidade de vida a partir da reorganização das ações de saúde e sua articulação intersetorial. Idéia presente desde o modelo de CIDADES SAUDÁVEIS.
} 
da ação comunitária, Desenvolvimento de habilidades pessoais, e Reorientação do sistema de saúde. Assim, buscava-se, com a promoção da saúde, a formulação de políticas públicas saudáveis que tivessem influência sobre a população, com a intenção de fortalecer a saúde de todos. (BUSS, 2000)

Inspirado pela promoção, o modelo das Cidades Saudáveis foi introduzido desde o final de 1980 no Brasil a partir de uma proposta da OPAS, que articula o conceito dos distritos sanitários com uma lógica um pouco menos municipalista, prevendo organização, hierarquização e articulação da rede.

\begin{abstract}
A noção de "cidades saudáveis" implica uma visão ampliada da gestão governamental que inclui a promoção da cidadania e o envolvimento criativo das organizações "comunitárias" no planejamento e execução das ações intersetoriais dirigidas à melhoria das condições de vida e saúde, principalmente em áreas territoriais das grandes cidades onde se concentra a população exposta a uma concentração de riscos vinculados à precariedade das condições de vida, incluindo fatores econômicos, ambientais e culturais (WESTPHAL, 1997; MALIK, 1997; KEINERT, 1997; FERRAZ, 1999; RADIS, 2000; apud TEIXEIRA, 2000, p. 45 e 46).
\end{abstract}

Segundo TEIXEIRA (2000) esse debate traz a possibilidade de reorientação das práticas que possam incidir sobre as condições e modos de vida da população, produzindo efeitos diretos e indiretos sobre o perfil de necessidades e demandas que serão apresentadas ao sistema no futuro. Introduziria, assim, uma perspectiva de temporalidade ao processo saúde-doença a partir da compreensão de que diversos fatores influenciam no modo de vida da população e levando em conta desafios impostos pela transição demográfica e epidemiológica.

A proposta de Saudicidade do município de Curitiba propunha uma lógica semelhante a dos SILOS para a organização dos serviços, mas trazia a articulação intersetorial de forma inovadora e como decisiva para o enfrentamento dos determinantes sociais ${ }^{15}$ dos problemas de saúde, assim reconhecia e identificava de forma mais ampla a multifatorialidade dos problemas de saúde.

Essa proposta já trazia os agentes comunitários como sujeitos importantes para o processo de articulação de ações no território. Ela teve seu início em 1979 e

\footnotetext{
${ }^{15}$ A idéia dos determinantes sociais da saúde considera que os problemas de saúde tem causas amplas e são diretamente influenciados pelo meio e contexto. Presente desde o modelo SAUDICIDADE.
} 
por mais de duas décadas se manteve em continuidade devido a permanência de governos com afinidades político-ideológicas.

Durante esse período, pode-se investir na qualificação dos demais serviços da rede mas o principal elemento dessa proposta foi a produção de saúde a partir de outros arranjos e encontros nos territórios ${ }^{16}$ e não necessariamente dentro dos serviços de saúde.

O modelo Em Defesa da Vida, formulado pelo LAPA-UNICAMP, no final da década de 80, reflete um esforço de parcela dos pensadores do campo da Saúde Coletiva brasileira em produzir estratégias de superação do modelo médico-hegemônico. Esta proposta também foi inspirada em outras experiências desenvolvidas de forma isolada em alguns municípios como Volta Redonda, Belo Horizonte e Betim, etc. Propunha-se uma gestão democrática ${ }^{17}$ com envolvimento ativo dos trabalhadores na produção de mudanças no cotidiano das práticas, busca de contribuições da saúde coletiva e mental para inovar arranjos e ferramentas para a produção do cuidado, entre outros elementos. Procurava-se, a partir do cotidiano, produzir um novo desenho organizacional para os serviços, para a gestão e para as práticas de saúde, pensando não somente a atenção básica, mas também o hospital e o arranjo das redes de atenção à saúde (uns trabalhando com o conceito da integralidade, outros com a clínica ampliada).

Essa proposta buscava contemplar os princípios constitucionais, dialogando com os conceitos do planejamento estratégico situacional de Matus e Testa e buscando lidar com as questões do trabalho médico e do cuidado individual. Buscava superar as barreiras criadas por idéias que opunham coletivo e individual, epidemiologia e clínica. Buscava produzir cuidado individual conectado ao coletivo. Por isso, sua principal ação envolvia a relação dos trabalhadores com o Estado e com os usuários e, a partir destas, sua atuação para agenciar a produção da atenção à saúde. (Merhy et. al., 2004)

A experiência procurou abrir as portas dos serviços para o diálogo com a população com o objetivo de ampliar a escuta para que as demandas pudessem

\footnotetext{
${ }^{16}$ Aqui o conceito de território é de espaço de articulação da comunidade e das acões de saúde, espaço de promoção da saúde, e espaço e locus de ação do agente comunitário da saúde. Esse conceito estev presente na produção do modelo de SAUDICIDADE.

${ }^{17}$ A gestão compartilhada e/ou participativa se caracteriza pela participacão ativa do conjunto de trabalhadores e gestores na produção de mudanças no cotidiano das práticas de saúde. Idéia que esteve presente na produção do modelo EM DEFESA DA VIDA.
} 
vir dos usuários. Posteriormente, para atender estas demandas, o serviço era organizado pelo conjunto da equipe com a participação da comunidade, trabalhava-se com equipes multiprofissionais e mais de uma especialidade básica médica (pediatra, clínico e ginecologista), já identificando a complexidade das necessidades a serem trabalhadas.

Nessa experiência, foi testado o acolhimento ${ }^{18}$ como estratégia de qualificação da escuta e da identificação de necessidades. A gestão das unidades era feita de forma colegiada e o diálogo entre trabalhadores e gestores era estimulado e aproximado. Procurava-se inventar formas de lidar com as apostas da reforma sanitária, construir discursos de forma mais horizontal e, por fim, fabricar ações que interferiram diretamente na realidade. (Merhy et. al., 2004)

Segundo Merhy (2004) um modelo Em Defesa da Vida deve pensar em como ampliar a dimensão cuidadora do trabalho em saúde, desencadeando processos mais conjuntos e partilhados no interior da equipe e junto aos usuários. Isso para melhorar a eficácia e adequabilidade da ação específica com os processos usuários centrados, assumindo e reconhecendo que certas abordagens profissionais, em certas circunstâncias, são, de fato, mais eficazes que outras, contudo, não deve permitir que uma profissão se imponha sobre a outra.

A responsabilização dos profissionais e das equipes por seus atos cuidadores, bem como o desenvolvimento de avaliações mais coletivas do processo de trabalho, podem apoiar o processo de o trabalho nos serviços de saúde, modificando a maneira de organizar as relações de agencimento de compromissos nos processos de produção dos atos de saúde.

Nessa altura, início dos anos 90, a Saúde Coletiva já era um campo estruturado, havia muitos programas depós-graduação em saúde coletiva e, ao longo do tempo, foram sendo produzidos estudos e intervenções por alguns grupos de universidades. Foram, portanto, ofertados novos conhecimentos que poderiam servir de referência para mudanças no sistema de saúde.

Assim, reconhece-se um esforço conceitual importante para compreender os processos de adoecimento em cada população e território, e, para propor modos de organização do sistema e das práticas de saúde. Ou seja, nesse momento, o

\footnotetext{
${ }^{18}$ Escuta qualificada na porta de entrada para encaminhamento eficiente. Idéia presente desde o modelo EM DEFESA DA VIDA.
} 
campo da saúde coletiva aparecia como formulador de conceitos-ferramentas ou conhecimentos-estratégias que auxiliavam na implementação de políticas públicas de atenção à saúde.

Se é correta essa afirmação, percebe-se a aproximação entre campo científico e política pública e a diferença entre eles é quase imperceptível a medida que tanto o campo quanto a política aprendem com as experiências para ressignificarem os saberes e as práticas que os constituem.

Algumas dessas experiências explicitadas acima buscaram potencializar especialmente o diálogo entre a realidade e os textos produzidos pelo movimento sanitário.

Momento inicial, muitas questões em aberto, interrogações, muitas surpresas nas tentativas de produzir mudanças de gestão e de práticas de saúde à luz das apostas do SUS. Na tentativa de inovar e inventar outros formatos cuidadores que pudessem produzir a política na prática inspirada nos textos e discursos, foram sendo inventados diferentes estratégias assistenciais adaptadas a cada realidade.

Ainda nesse momento, nota-se que muitos dos protagonistas do movimento sanitário estavam nas universidades e buscavam ter relação direta com os serviços e sistemas de saúde para apoiar a construção dessas estratégias.

Esse movimento de encontro entre academia e serviço foi fundamental nesses primeiros anos de desenvolvimento do SUS no país.

Para o grupo que se organiza em torno do Instituto de Saúde Coletiva da UFBa, a noção de risco e, especialmente a identificação dos fatores de risco envolvidos na determinação das doenças, possibilitaria a modernização das estratégias de ação no campo da saúde pública. A vigilância em saúde enquanto proposta de organização assistencial prevê um conjunto de práticas orientadas a controlar os determinantes, os riscos e os danos, a partir de uma nova organização das ações e serviços de saúde que consideram cada território e cada população. Segundo TEIXEIRA et al. (1998), esse modelo apresenta sete categorias: intervenção sobre problemas de saúde (danos, riscos e/ou determinantes); ênfase em problemas que requerem atenção e acompanhamento contínuo; operacionalização do conceito de risco; articulação entre ações promocionais, preventivas e curativas; 
atuação intersetorial; ações sobre o território; e intervenção sob a forma de operações.

Essa proposta influencia a organização da atenção básica de forma importante, pois foi incorporada, junto com as ações programáricas, no PACS (Programa de Agentes Comunitários de Saúde) e depois na saúde da família.

0 modelo assistencial baseado nas ações programáticas ${ }^{19}$ considerava a programação, advinda das concepções do planejamento, como base para a reorganização do sistema, ampliando os atendimentos individuais, estabelecendo atividades de rotina e eventuais. A programação, apesar de visar o coletivo ou o desenvolvimento de ações para o coletivo, define como seu agente o médico sanitarista, que atua baseado em diagnósticos epidemiológicos para prevenção ou tratamento de doenças que assolam parcela da população. Dessa idéia de organização da programação definem-se os ditos programas específicos de saúde e as ações programáticas de saúde. (NEMES, 1993)

Para TEIXEIRA (2006), a proposta das ações programáticas se constitui como alternativa para implementação dos "pacotes tecnológicos" a serem incorporados aos serviços de saúde. São semelhantes a normas técnicas de intervenção, já que as recomendações de cada ação programática derivam de estudos científicos sobre os problemas de saúde relacionados, contudo, desconsideram as especificidades de cada território e de cada população, portanto, são verticais, normativos, prescritivos.

Assim, essa proposta busca

\begin{abstract}
o aperfeiçoamento das práticas pela incorporação crítica dos saberes, conhecimentos e tecnologias disponíveis para delimitação de objetos de intervenção referidos às necessidades de grupos populacionais específicos (mulheres, adolescentes, idosos, etc) ou problemas específicos que se apresentam na prática clínica, relacionando-os no espaço social mais amplo das determinações sociais e políticas (TEIXEIRA, 2006, p. 35).
\end{abstract}

Segundo TEIXEIRA (2006), apesar da ênfase na utilização da epidemiologia como componente definidor das ações programáticas, essa epidemiologia se limitou a influenciar a clínica. As ações programáticas foram organizadas como pacotes de

\footnotetext{
${ }^{19}$ Aa ações programáticas podem ser entendidas com a idéia de que a assistência deve ser organizada a partir de pacotes de ofertas assistenciais para determinados grupos populacionais, que agregam características comuns em relação ao risco do adoecimento, seja faixa etária, seja sexo e idade, seja situação de saúde.
} 
ofertas assistenciais, sendo que, entre elas, estavam os que eram possíveis de serem realizados no âmbito da atenção básica.

Desde os anos 80, já havia experiências que contavam com a figura dos Agentes Comunitários de Saúde e, finalmente, em 1991, foi proposto pelo Ministério da Saúde o Programa de Agentes Comunitários de Saúde (PACS), muito difundido, especialmente no Nordeste brasileiro onde existiam os maiores vazios assistenciais.

Baseado na lógica da epidemiologia, das ações programáticas, e reconhecendo a necessidade de ampliar as ações de atenção básica, o PACS foi fabricado para atender esses interesses e chegar mais perto da população, organizando o processo de trabalho do programa com ações centradas, especialmente, nas práticas de prevenção, educação e promoção da saúde, a exemplo da prevenção da mortalidade materna e infantil. (Sousa, 2001)

Não podemos esquecer que, especialmente no Norte e Nordeste brasileiro, existiam condições muito adversas de vida e saúde, casos de desnutrição severos e a mortalidade por doenças advindas de baixas condições de vida e de higiene era comum. Nesse cenário, o PACS foi sendo implementado. (ROSA e LABATE, 2005)

O PACS teve um papel fundamental para, em parte, ampliar o diálogo sobre a saúde com a população, no entanto, efetivamente, a clínica não estava sendo desenvolvida e as equipes precisavam ser ampliadas para promoverem mais ações de saúde. Sendo assim, o Ministério da Saúde, em 1994, propôs a reorganização da atenção básica ou da atenção primária por meio do programa que, naquele momento, se estruturou como estratégia assistencial e, mais tarde, organizou-se como política de Saúde da Família. (ROSA e LABATE, 2005)

0 Programa de Saúde da Família ${ }^{20}$ (PSF) articulou práticas propostas anteriormente pelos SILOS, pela promoção da saúde, pela programação da saúde e pela vigilância da saúde. (FEUERWERKER, 2005; TEIXEIRA, 2006)

Nesse momento, falavam da saúde da família como base para a reorganização de um modelo de atenção à saúde do SUS para todo o território nacional, com

\footnotetext{
${ }^{20}$ O conceito de Saúde da Família aqui trazido é de modelo de atenção à saúde organizado para ampliação das ações de saúde no território baseado nos programas assistenciais e na relação dos trabalhadores com a comunidade e território.
} 
potencial de mudança na organização da média e alta complexidade a partir de políticas de controle e regulação. (TEIXEIRA, 2006)

É interessante observar aqui que havia uma formulação proposta, que estava em disputa, e que era divulgada e apoiada pelo Ministério da Saúde, ator relevante e financiador do SUS. Outros atores se posicionavam, apoiavam ou discordavam das propostas do programa. Os reflexos dessas disputas no cotidiano operativo do PSF foram observados ao longo dos anos e destacaremos adiante.

Em 1994, o Ministério da Saúde lançou o primeiro documento orientador chamado "Programa Saúde da Família: Saúde dentro de casa". Já nesse documento encontram-se alguns conceitos que traduziam a intencionalidade desse modelo assistencial proposto para o SUS, sendo a atenção básica desenvolvida a partir do PSF o componente ordenador do restante da rede de serviços.

Deve-se ter em mente que o objetivo geral da estratégia Saúde da Família é de "contribuir para a reorientação do modelo assistencial a partir da atenção básica, em conformidade com os princípios do Sistema Unico de Saúde, imprimindo urna nova dinâmica de atuação nas unidades básicas de saúde, com definição de responsabilidades entre os serviços de saúde e a população". E, para atingí-lo, a Equipe de Saúde da Família (ESF) precisa conhecer a realidade da população sob sua responsabilidade: os contextos familiares e a vida comunitária, desenvolvendo um processo de planejamento pactuado em cada uma de suas fases: na programação, na execução e na avaliação (BRASIL, 2000, p.10).

Em 1996, com a publicaçãoo da NOB 01/96, o financiamento do programa passa a considerar critérios populacionais para o desenvolvimento das atividades assistenciais, sendo influenciado pela lógica da programação. A partir desse momento, o financiamento da atenção básica passou a ser per capita e não por produção. E a Saúde da Família incentivada a partir do PAB variável.

As transferências federais aos municípios que aderissem ao PSF nesse momento praticamente cobriam os custos das equipes. Esse movimento foi fundamental para a expansão do programa, especialmente nas regiões Norte e Nordeste.

Ao lado da expansão de cobertura, havia tensionamentos em função do subfinanciamento geral a que o SUS já estava submetio. Foram criados dispositivos de controle e novos critérios para adesão e implementação do PSF. Tais tensões fortaleciam o vetor "cesta básica" na construção da saúde da família: 
equipe mínima, agenda mínima e grande número de famílias a serem acompanhadas em cada território.

Aqui já é possível perceber problemas. A saúde da família propicia o encontro da equipe com a população no território, mas define a priori a agenda de trabalho. Então, apesar de proporcionar o conhecimento da realidade, os arranjos e a agenda de trabalhos são fixos, do Oiapoque ao Chuí. É preciso reconhecer, no entanto, que a proposta estava orientada aos municípios menores e mais pobres. Era estratégico que os municípios pequenos também pudessem ser atores nesse processo.

Havia nesse momento uma conjunção de interesses para a expansão do programa. O Ministério da Saúde estava imbuído da missão de universalizar o SUS. O Banco Mundial estava interessado em apoiar sistemas de saúde que ampliassem a cobertura e impactassem nos principais indicadores de saúde. Os gestores municipais de saúde estavam preocupados em ampliar as ações de saúde e em obter apoio federal para tal.

Muitos atores do campo da Saúde Coletiva concordaram que esse modelo seria suficiente para ampliar e qualificar a atenção para todos e que seria possível inverter o modelo de atenção a partir da atenção básica organizada segundo saúde da família.

Em 1998, a lógica do financiamento foi aperfeiçoada e, garantiu que os recursos do Plano Plurianual referentes aos repasses do PAB, fossem transferidos por mecanismo fundo a fundo ao conjunto dos municípios, e isso os incentivava a aderirem ao programa.

Em 1999, o Ministério da Saúde publicou o Manual para Organização da Atenção Básica no SUS e implantou o Pacto de Indicadores da Atenção Básica. 0 documento traz um conjunto de conceitos e idéias para enfrentar as dificuldades do processo de implantação de um novo modelo de atenção. Esse Pacto de Indicadores demonstra que a lógica da epidemiologia e da vigilância estava implícita e que os mecanismos de controle estavam convergentes com os mecanismos de financiamento. Ou seja, estava em implantação o que, por muitos ficou conhecida como uma política indutora, Segundo a qual poderiam receber financiamento federal os municípios que cumprissem com as regras propostas pelo Ministério da Saúde. 
Destacamos que o financiamento, pensado como dispositivo da política para induzir sua implementação, limita ativamente a possibilidade de produção autônoma e criativa de cada território. Por isso, a expressão da política como indutora pode ser questionada. Induz? Reproduz? Captura? Ou se produz a partir de outra perspectiva nos encontros, nos territórios?

Saúde da Família passou a ser adotada cada vez mais como estratégia preferencial para organização da atenção básica, que passou também a ser designada como a porta de entrada preferencial de todo o sistema de saúde. Apostava-se que o modelo proposto fosse capaz de resolver e/ou evitar a maioria dos problemas de saúde, desenvolver e articular ações coletivas e intersetoriais que impactassem nos determinantes do processo saúde e doença, assim como melhorasse a qualidade de vida e trabalho da população.

As ações deveriam ser pautadas por um processo de planejamento e programação da saúde a partir dos problemas de saúde identificados no território. Nessa perspectiva, a epidemiologia aparece como ferramenta de planejamento importante para a programação. 0 território ${ }^{21}$ no processo de atenção básica por meio da implementação da Saúde da Família se configura como o componente-objeto do processo de cuidado.

O modelo da vigilância em saúde por dentro da estratégia de saúde da família foi eficaz para interferir na mortalidade infantil, prevenir e vigiar especialmente as doenças infecto-parasitárias e promover educação, atividades educativas de conscientização assim como ampliar o pacote de imunizações. (Sousa, 2001)

Merhy et. al. (2004) retomou a idéia de que o Ministério da Saúde, em seus documentos oficiais, expressou que o PSF surgiu com o objetivo de superação do modelo de assistência marcado por serviços hospitalares e centrado nos atendimentos médicos e ações curativas, ele pretendia reorganizar a atenção básica no país. O PSF seria a proposta para substituição das práticas convencionais de assistência por um novo processo de trabalho centrado na

\footnotetext{
${ }^{21} \mathrm{O}$ conceito de território/população construído pelo modelo de Saúde da Família tem o sentido de locus de produção e articulação de atividades de prevenção, promoção, educação e recuperação da saúde para ações pertencentes ao nível básico de atenção à saúde. Espaço e população adscrita pela equipe de Saúde da Família, parte da base da pirâmide, sendo este ordenador do cuidado na rede.
} 
vigilância em saúde e baseado na territorialização para organização das suas ações.

Segundo SOUZA (2001), o processo de implantação do PSF foi marcado por alguns elementos que posteriormente influenciaram diretamente no seu modo de funcionamento. O PSF busca substituir o modelo hegemônico da prática médica flexneriana, que entende a saúde como ausência de doença, por um modo de produzir saúde a partir da qualidade de vida, com influência direta do meio e da sociedade nesse modo de produção.

Segundo essa mesma autora, o PSF radicaliza o princípio da universalidade e visa garantir o direito social à saúde, avançando no cenário existente anteriormente onde não havia acesso ampliado. Busca integrar práticas individuais e coletivas a partir de uma integração da epidemiologia, com a clínica e o componente social, assim consegue mapear o risco e prioriza o cuidado. Busca defender a equipe multiprofissional diferentemente das práticas tradicionais centradas no profissional médico.

O modelo clássico de assistência tem o hospital como serviço estratégico onde são construídos os espaços de poder do saber médico a partir de uma prática curativa focada na doença e no uso da tecnologia, no PSF, essa lógica não existiria e se reconhece como o melhor lugar para produção do cuidado, a casa ou o espaço mais próximo da casa das famílias. E, por último, indica uma mudança significativa foi na inversão da lógica de produção da saúde pois antes o doente procurava o profissional e o serviço, e, com o PSF, a lógica é que a equipe procure os usuários e os ajude na prevenção e promoção ou com o intuito de encaminhálo para um outro nível de cuidado.

Já identificamos que existiam diversos interesses em ação nesse processo de produção e elaboração do programa de Saúde da Família. Apesar dos textos e do dispositivo do financiamento que buscava induzir a implementação desse modelo, ao longo do tempo houve o reconhecimento de que a Saúde da Família estava sendo produzida de diferentes formas e com diferentes desafios nos diferentes territórios, com dificuldades para cumprir muitas das apostas originais.

Em 1999, houve a criação do Departamento de Atenção Básica, do Ministério da Saúde, que se ocupou de consolidar o modelo, fortalecê-lo e ampliá-lo. No 
entanto, esse departamento identificou alguns desafios a serem enfrentados para ampliar e qualificar o programa.

Avaliava-se que o modelo de atenção preconizado pelo PSF não estava sendo plenamente implementado e acreditava-se que um dos motivos para tal era a falta de conhecimentos dos profissionais para atuar nesse novo modelo. Portanto, era necessário ensinar aos profissionais como atuar nesse espaço de produção da saúde no território/população e a solução apresentada foram inúmeras capacitações profissionais.

Em 1997, começaram a ocorrer as transferências de recursos, por meio de de convênios, para a implementação dos Pólos de Capacitação em Saúde da Família. Os pólos tinham o objetivo promover articulações para capacitação, formação e educação permanente para os trabalhadores da saúde da família. Em 1999, já eram 21 pólos no país envolvendo cerca de 100 Instituições de Ensino Superior e secretarias municipais e estaduais de saúde. (Souza, 2001)

Segundo Souza (2001), esses pólos produziram uma rede comprometida com a integração ensino-serviço com o objetivo de qualificar e desenvolver os trabalhadores da Saúde da Família. Considerava- se que a entrada desses atores em cena na política de atenção básica seria importante na disputa desse modelo de produção da atenção em saúde no SUS.

Várias iniciativas - I Mostra de Produção em Saúde da Família (1995), Revista Brasileira em Saúde da Família (1999), série Cadernos de Atenção Básica (1999) - tinham o objetivo de fazer circular experiências e serem informativos para gestores e trabalhadores.

Também em 1999 foi lançado o Projeto de Residência em Saúde da Família. (Souza, 2001). Vários projetos foram construídos em todo o país, principalmente de Residência Multiprofisisonal, mas também alguns de Residência de Medicina de Família e Comunidade. Como existia a crença na necessidade de mudança na formação para fortalecer a implementação da Saúde da Família, as residências, capacitações e especializações eram consideradas estratégias indispensáveis para implementação desse modelo de atenção.

Se de um lado, o PSF traz na sua concepção teórica a tradição herdada da Vigilância à Saúde, por outro, reconhece que a mudança do modelo assistencial dá-se a partir da reorganização do processo de trabalho. Partindo de uma crítica ao atual modelo, que tem nas ações e saberes médicos a 
centralidade dos modos de fazer a assistência, propõe um novo modo de operar o trabalho em saúde. A alternativa pensada estrutura o trabalho assistencial a partir de equipes multiprofissionais (FRANCO e MERHY, 1999, p. 8).

Mas a proposta da Saúde da Família apresenta

múltiplas tensões na organização do trabalho na Saúde da Família. Apesar das práticas com o coletivo, com as famílias, nas casas, nos locais de trabalho e convivência serem teoricamente uma atribuição do conjunto da equipe, elas são assumidas principalmente pelos agentes comunitários, seguidos pelos profissionais da enfermagem. A carga de atenção por meio das consultas clínicas é extremamente pesada e ocupa grande parte da agenda dos médicos. Portanto, sem romper o isolamento, sem a produção de novas tecnologias para o cuidado em saúde e sem colocar a construção de linhas de cuidado na agenda da gestão do sistema (rompendo com o isolamento da atenção básica e com a hierarquização burocrática), dificilmente será possível produzir atenção à saúde de qualidade, atendendo às expectativas dos usuários, todos esses elementos indispensáveis para a consolidação política do SUS (FEUERWERKER, 2005, p. 495 e 496).

Os desafios eram imensos para garantir a integralidade e a resposta às realidades de saúde impostas pela diversidade regional. Seriam necessárias formulações articuladas, novos arranjos, para produzir desde a ampliação de acesso a novos equipamentos assistenciais até propostas para organização e articulação do conjunto dos serviços.

No entanto, a partir da ideia de que a partir da atenção báica/saúde da família se reorganizaria todo o sistema de saúde, houve uma concentração de proposições nessa área, que permaneceu sendo construída de modo apartado do restante dos serviços de saúde. Atenção especializada e hospitalar foram objeto de escassas reflexões e experiências inovadoras, apesar de concentrarem boa parte dos recursos financeiros do sistema.

E todo aquele clima de debate, formulações, experimentações e diálogos, ao longo dos anos 90, esfriou. Nos anos 2000, no campo da atenção básica, fixou-se a escolha em torno da saúde da família e da vigilância em saúde como organizadora das práticas. E quase um pensamento único passou a vigir. Poucas eram as vozes dissonantes.

Antes de 1994, a atenção básica era custeada a partir do registro da produção realizada pela tabela SIA/SUS. Reconhecia-se que a proposta precisava ter outra referência de financiamento coerente com outros modos de produzir atenção. 
O marco na mudança na modalidade do PSF foi a NOB 01/1996, que além de criar novas modalidades de habilitação e formas de repasses financeiros, criou o Piso de Atenção Básica (PAB) em dois formatos: fixo e variável. O PAB fixo representava um valor per capita a ser repassado para todos os municípios de acordo com sua população; o PAB variável foi composto por um conjunto de incentivos a ser repassado de acordo com ações e programas específicos definidos.

Com essa nova forma de financiamento da atenção básica, Vasconcelos (2013) afirma que a concepção de atenção básica, adotada pelo Ministério da Saúde e reforçada pelas agências internacionais, era de um programa focalizado e seletivo, com uma cesta restrita de serviços conforme definido na literatura como Atenção Primária Seletiva.

Contudo, apesar de o per capita desatrelar o financiamento da capacidade instalada e da produção de serviços, o Ministério da Saúde usou o PAB variável para instituir o financiamento como indutor da adesão de a programas e ações. E, ao longo do tempo, o Ministério restringiu ao PAB fixo o financiamento da atenção básica aos municípios que não aderiam ao programa. Dessa forma, acabou havendo um desfinanciamento de qualquer outra modelagem de atenção básica que não atendia aos critérios propostos à saúde da Família.

A Saúde da Família, então, cresceu dos municípios menor e mais pobres para os maiores, em suas regiões de maior vulnerabilidade social, do nordeste e do norte para o sudeste e para o sul. Por isso, também, é comum ser designada como um modelo de saúde para pobres.

Os municípios que aderiram parciamente ao PSF, passaram a se responsabilizar praticamente sozinhos pelo financiamento da atenção básica nas chamadas "UBS tradicionais".

Somente em 1998 houve a regularização na transferência do PAB fundo a fundo e novos incentivos foram criados. Em 1999, os valores do PAB foram reajustados e foi incluída uma nova forma de cálculo para a transferência dos incentivos do PAB variável, aumentando o repasse para os municípios com maior cobertura do PSF. Mais uma vez, essa medida valoriza os municípios que aderiram ao programa, reforçando a importância da adesão aos demais municípios, no entanto, desfinancia a atenção básica nos municípios que tem dificuldades na sua 
implementação ou não optaram pelo modelo proposto. Dessa forma, entendendo o papel do financiamento federal no SUS, podemos entender que o desfinaciamento para essa política impacta no próprio desempenho do SUS nos diversos municípios.

Desde o ano 2000, foram incluídas as equipes de saúde bucal - compostas po um cirurgião-dentista, um técnico de higiene dental e um agente de consultório dentário - nas equipes da estratégia de Saúde da Família. Ao longo desses anos, a cesta básica ofertada foi ampliada, mais no discurso que na prática.

Em 2001, com a NOAS, a atenção básica tem sua responsabilidade assistencial ampliada e, para sustentar essa mudança, foi criado o PAB ampliado que tinha como objetivo financiar mais programas, priorizando o controle da tuberculose, a eliminação da hanseníase, o controle da hipertensão arterial, o controle da diabetes mellitus e a saúde da criança, da mulher e bucal. A partir dessa priorização, é possível identificar a influência da epidemiologia determinando as prioridades assistenciais, a influência da vigilância exercendo um certo controle sobre os agravos e as doenças e a influência das ações programáticas definindo o cardápio a ser ofertado no modelo de Saúde da Família.

Esse modo de organizar a atenção básica e induzir a implantação do PSF pode ser identificado quando se observa que, entre 1998 e 2003, os valores repassados pelo PAB fixo (que vão para todos os municípios) praticamente não foram alterados, mas os valores repassados pelo PAB variável cresceram muito; foram sendo criados mais e mais incentivos de acordo com os programas propostos.

Esse movimento demonstra mais uma vez a aposta política na indução baseada no financiamento. Os gestores de modo geral acreditavam ser possível induzir uma política., principalmente num cenário de poderes tão desequilibrado. 0 gestor federal, responsável por cerca de $50 \%$ do orçamento que custeia a saúde, tem grande peso. Quando o Ministério da Saúde apresenta regras e critérios atrelados ao repasse do recurso financeiro, ele exerce sobre os demais gestores uma pressão importante e definidora da política de saúde no conjunto dos estados e municípios.

Outro exemplo que corrobora essa percepção foi a Portaria GM n 1.350 de 24 de julho de 2002 que instituiu um incentivo financeiro adicional ao PSF e PACS vinculado a idéia de qualificação dos municípios. A avaliação da qualificação 
seria feita a partir de critérios específicos definidos e os municípios qualificados para a Saúde da Família receberiam uma parcela única anual adicional aos demais recursos que serviria como uma espécie de bonificação para quem conseguisse seguir a receita do programa. Nos dias de hoje, ao analisar tal portaria, identificamos ação indutora semelhante reeditada e readequada por meio do Programa de Melhoria, Acesso e Qualidade da Atenção Básica (PMAQ). Em 2003, com o início do governo Lula, havia uma avaliação de que o PSF teria chegado a um certo esgotamento, em função de vários desafios que limitavam sua expansão, especialmente nos grandes centros urbanos e nos lugares muito afastados. Um desses desafios era a indisponibilidade de profissionais de saúde, tanto do ponto de vista de provimento para o conjunto de serviços existentes, como do ponto de vista da qualificação necessária para atuação no programa. Também não havia financiamento bem definido e suficiente para o custeio de tantos dispositivos atrelados ao programa.

Até esse momento, apesar do discurso de prioridade para a atenção básica, tinha havido proporcionalmente um crescimento maior do financiamento da atenção hospitalar e especializada, um claro resultado da disputa pela manutenção do modelo médico hegemônico continuasse.

Diante desse cenário, são feitas mudanças no financiamento da atenção básica e os valores do PAB fixo são reajustados e corrigidos. Novos incentivos para regiões mais pobres, com baixo IDH, populações ribeirinhas, quilombolas etc foram criados, incluídos no PAB variável.Também foi criado o Programa de Expansão e Consolidação da Saúde da Família (PROESF) com o objetivo de ampliar a Saúde da Família nos municípios com mais de 100 mil habitantes.

Tudo isso resultou em um aumento real de cobertura, pois, em 2004, a saúde da família estava presente em 80,2\% dos municípios, garantindo cobertura para 39\% da população, o que correspondia a 69,1 milhões de pessoas; já em 2006, a cobertura aumentou para 46,2\%, garantindo acesso à Saúde da Família para 85,7 milhões de pessoas.

Em 2006, duas portarias do Ministério da Saúde produzem mudanças na política de atenção básica. A Portaria GM no 399, de 22 de março de 2006, institui os Pactos pela Saúde que tinham o objetivo de modificar a relação intergestores, 
produzindo um processo de pactuação que definiria o financiamento de forma compartilhada.

Para atenção básica, os Pactos pela Vida e pela Gestão evidenciam um forte incentivo para que haja qualificação e expansão da Saúde da Família e priorizam programas que tem muitas de suas ações presentes na atenção básica. Também, definem um bloco de financiamento exclusivo para a atenção básica.

A Política Nacional de Atenção Básica foi publicada por meio da Portaria GM no 648, de 28 de março de 2006. Novos conceitos trazidos para o texto expressam o reconhecimento de que, do modo como vinha sendo implementada, a Saúde da Família não vinha apresentando potência para a qualificação da atenção. A portaria define que

A Atenção Básica caracteriza-se por um conjunto de ações de
saúde, no âmbito individual e coletivo, que abrangem a
promoção e a proteção da saúde, a prevenção de agravos, o
diagnóstico, o tratamento, a reabilitação e a manutenção da
saúde. É desenvolvida por meio do exercício de práticas
gerenciais e sanitárias democráticas e participativas, sob forma
de trabalho em equipe, dirigidas a populações de territórios
bem delimitados, pelas quais assume a responsabilidade
sanitária, considerando a dinamicidade existente no território
em que vivem essas populações. Utiliza tecnologias de elevada
complexidade e baixa densidade, que devem resolver os
problemas de saúde de maior freqüência e relevância em seu
território. É o contato preferencial dos usuários com os
sistemas de saúde. Orienta-se pelos princípios da
universalidade, da acessibilidade e da coordenação do cuidado,
do vínculo e continuidade, da integralidade, da
responsabilização, da humanização, da equidade e da
participação social. A Atenção Básica considera o sujeito em
sua singularidade, na complexidade, na integralidade e na
inserção sócio-cultural e busca a promoção de sua saúde, a
prevenção e tratamento de doenças e a redução de danos ou de
sofrimentos que possam comprometer suas possibilidades de
viver de modo saudável. A Atenção Básica tem a Saúde da
Família como estratégia prioritária para sua organização de
acordo com os preceitos do Sistema Único de Saúde (BRASIL,
2006).

Antes do Pacto, o financiamento atrelado ao PAB variável era para ações de vigilância, PACS, farmácia básica, Saúde da Família e combate as carências nutricionais. Agora, muitos desses elementos são trazidos para o PAB fixo e o variável ficou atrelado a outros dispositivos dirigidos somente para municípios que adotassem a Saúde da Família. Esse foi um movimento do Pacto: a tentativa de desmanchar "as caixinhas" por meio das quais as transferências do Ministério eram feitas para os municípios. 0 objetivo era ampliar a governabilidade dos 
municípios na contextualização das políticas - partindo de um pacto em relação a princípios e diretrizes.

Os novos conceitos incorporados à política nacional de atenção básica tinham a ver com processo de trabalho e práticas de saúde. Conceitos advindos de todas as vertentes da "defesa da vida" e de outras propostas que pensavam a produção do cuidado em saúde foram incorporados ao texto: acolhimento, vínculo, continuidade do cuidado, integralidade etc.

Não estão explicitadas as razões para tal incorporação, mas pode-se imaginar que tenham a ver com as dificuldades que vinham sendo enfrentadas para transformar o modelo de atenção. Não só não tinha havido reorientação do sistema, como na própria atenção básica proliferavam modelos de clínica empobrecida, práticas médico-centradas etc.

No entanto esses conceitos foram incorporados sem penetrar no "coração" da saúde da família, já que o processo de trabalho e os modos de avalia-lo continuaram orientados pela vigilância em saúde e pelas ações programáticas. Não havia mudança de conceito, portanto, apenas uma justaposição, cujo sentido ou potência precisa ser interrogado.

Outras dificuldades, além da potência de mudança, voltaram a ser vocalizadas: a dificuldade de provimento de médicos, a precarização dos vínculos trabalhistas (já que a maior parte da expansão da saúde da família vinha sendo feito mediante a terceirização das contratações de trabalhadores), a rigidez em relação à composição da equipe etc.

Da mesma forma, os recursos já não mais cobriam as necessidades e estavam atrelados a esses diferentes programas e dispositivos ou a conformação da equipe. Nesse último aspecto, vários gestores verbalizavam sua inquietude pois o descredenciamento e, por consequência, o desfinanciamento de equipes por falta de algum profissional, acabava sendo um grande limitador para a sustentabilidade da Saúde da Família como modelo.

Apesar disso, a cobertura da Saúde da Família foi crescente ao longo dos anos. Segundo dados do próprio Ministério da Saúde, quando foi criado o PSF sua abrangência era de 3,51\%, em 1998 chegou a 6,57\% da população brasileira. Em dezembro de 1999, chegou em 29,9\% dos municípios brasileiros com uma cobertura de aproximadamente 14 milhões de brasileiros. Em 2002, já eram 54 
milhões de pessoas cobertas pela estratégia. Essa expansão é relevante do ponto de vista de ampliar o acesso a serviços de saúde no grande terroritório nacional mas não necessariamente em melhorar a saúde da população.

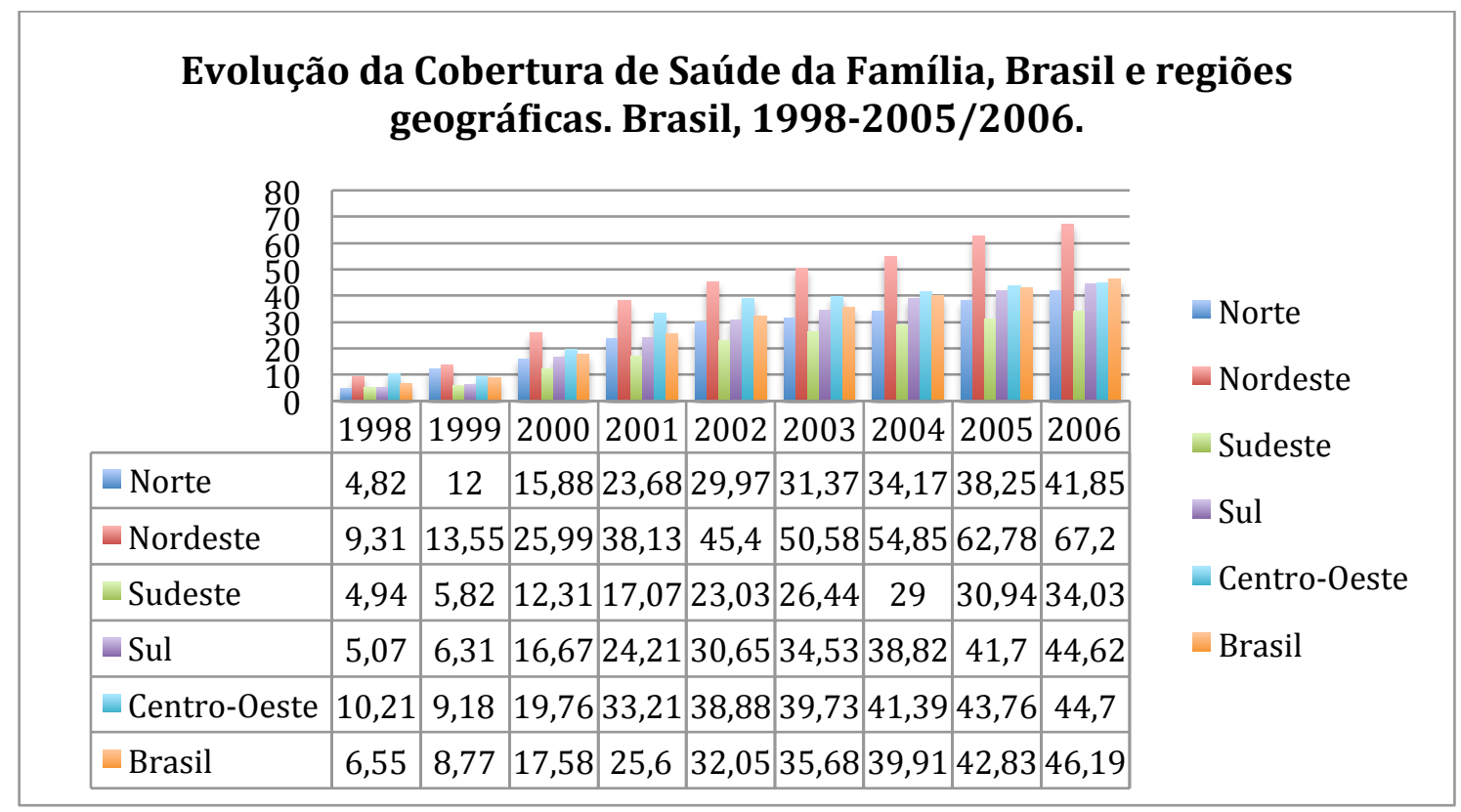

Gráfico adaptado do Documento "Saúde da Família no Brasil: uma análise de indicadores selecionados 1998-2005/20006" elaborado pelo Ministéro da Saúde, Brasil, 2006.

Nesse gráfico não é possível perceber que a concentração maior da Saúde da Família estava localizada em municípios pequenos, muitas vezes, mais pobres. Em 2006, segundo dados do documento do Ministério da Saúde, a cobertura da estratégia em municípios de pequeno porte era de $77 \%$ e nos municípios de grande porte era somente $32,05 \%$. Além disso, o grupo dos municípios com menor renda, em 2006, apresentava cobertura de 72,93\%, e o o grupo dos municípios com maior renda, apresentava cobertura de $28,87 \%$.

0 financiamento a partir de um bloco específico para a atenção básica também pode ser considerado um dispositivo da política e que definiu mecanismos de controle e monitoramente atrelados aos indicados do Pacto pela Saúde e Pacto de Gestão. A proposta do Pacto que potencialmente traria uma novidade para a relação intergestores foi reduzida a um conjunto de procedimentos burocratizados, já que a partir do início do segundo governo Lula o Ministério da Saúde deixou de apostar na renovação da relação intergestores como uma prioridade.

No início do governo Dilma, a Portaria GM n².488, de 21 de outubro de 2011, aprovou nova versão da Política Nacional de Atenção Básica, com modificações 
em diretrizes e normas para organização da atenção básica. 0 texto expressa os seguintes conceitos:

A atenção básica caracteriza-se por um conjunto de ações de saúde, no âmbito individual e coletivo, que abrange a promoção e a proteção da saúde, a prevenção de agravos, o diagnóstico, o tratamento, a reabilitação, a redução de danos e a manutenção da saúde com o objetivo de desenvolver uma atenção integral que impacte na situação de saúde e autonomia das pessoas e nos determinantes e condicionantes de saúde das coletividades. É desenvolvida por meio do exercício de práticas de cuidado e gestão, democreaticas e participativas, sob forma de trabalho em equipe, dirigidas a populações de territórios definidos, pelas quais assume a responsabilidade sanitária, considerando a dinamicidade existente no território em que vivem essas populações. Utiliza tecnologias de cuidado complexas e variadas que devem auxiliar no manejo das demandas e necessidades de saúde de maior frequência e relevância em seu território, observando critérios de risco, vulnerabilidade, resiliência e o imperativo ético de que toda demanda, necessidade de saúde ou sofrimento devem ser acolhidas. É desenvolvida com o mais alto grau de descentralização e capilaridade, próxima da vida das pessoas. Deve ser o contato preferencial dos usuários, a principal porta de entrada e centro de comunicação da Rede de Atenção à Saúde (Brasil, 2012, p. 19).

Novamente, alguns conceitos e dispositivos são incorporados na proposta política, sem que o "coração" da vigilância e das ações programáticas seja modificado. A mudança mais significativa foi a do financiamento da atenção básica.

A proposta previu um aumento em torno de $40 \%$ no valor total de recursos a serem investidos na política, recursos esses a serem repassados fundo a fundo ao conjunto de municípios. Foram criados extratos populacionais com características atreladas ao grau de pobreza e, quanto maior o percentual de população com maior grau de pobreza, maior seria o repasse do PAB fixo. (Brasil, 2012)

Dessa vez, a nova política pretendeu promover mais equidade na estruturação dos serviços de atenção, e o critério estava vinculado aos usuários e suas necessidades.

Também foi proposto um componente ligado a qualidade na Saúde da Família, relacionado a um processo de contratualização de indicadores e metas de resultado da qualidade, que premiaria as equipes com um incentivo financeiro. 0 Programa de Melhoria do Acesso e Qualidade da atenção básica foi estruturado a partir de instrumentos de pesquisa e contratualização. (Brasil, 2012) 
Muitos dos indicadores propostos já estavam presentes no Pacto, mas houve um diferencial no modo de produzir as informações e na relação com os gestores municipais e trabalhadores.

Ao invés de os dados/nformações serem produzidos/informados pelos gestores municipais, com aval dos espaços bipartites, eles passaram a ser produzidos a partir de uma coleta externa, assumida por várias universidades do país. Ao invés da relação de confiança intergestores, a intermediação de um terceiro.

A lógica do PMAQ está fortemente baseada no controle, na fiscalização e em incentivos financeiros, já que os municípios daas equipes que atingissem as metas pactuadas seriam contemplados com acréscimos de recursos.

Segue vigente o conceito da atenção básica como ordenadora das redes de atenção, mas agora pensadas de modo mais horizontal, requerendo pactuação e estratégias de conexão entre diferentes serviços. Antes o conceito era de porta de entrada do sistema, reforçava o modelo da pirâmide e colocava na responsabilidade da atenção básica o acesso seletivo aos demais níveis de atenção, bem como de produção de cuidado de forma integral.

O PACS, que ainda existia em alguns lugares independente da equipe de Saúde da Família, a partir da publicação da política, em 2011, foi considerado como estratégia de agentes comunitários da saúde e incorporado como um dos dispositivos da política, articulado à Saúde da Família sempre que possível. Em alguns territórios, isso não era viável porque havia dificuldades de provimento profissional para lugares de difícil acesso, pouca estrutura urbana e também para populações específicas como é o caso de comunidades de moradores de rua, indígenas, quilombolas, ribeirinhas e fluviais e etc.

Foram criados ou atualizados vários dispositivos da política, dentre os quais podemos destacar: o Núcleo de Apoio à Saúde da Família, as Equipes de Consultório na Rua, o Programa Saúde na Escola

Os Núcleos de Apoio à Saúde da Família (NASF) haviam sido criados em 2008 com o objetivo de ampliar a resolubilidade da atenção básica e, acoplando de modo matricial equipes amultiprofissionais às equipes de Saúde da Família. (Brasil, 2012)

As Equipes de Consultório na Rua têm responsabilidade pela atenção à saúde da população de rua, desenvolvendo ações no seu território itinerante e buscando 
se articular com os demais serviços de saúde para ampliar a integralidade do cuidado a essa população. (Brasil, 2012)

O programa Saúde na Escola (PSE) tinha o objetivo de promover ações que promovam a integralidade, tais como: avaliação clínica e psicossocial; promoção e prevenção que articulam práticas de formação e educação voltadas para promoção de vida mais saudável; e educação permanente para qualificação dos profissionais da educação e da saúde. (Brasil, 2012)

Além desses, também foram criados dispositivos como a Academia da Saúde, a estratégia de atenção domiciliar denominada Melhor em Casa, assim como o Telessaúde. Mais recentemente, foi criado o e-SUS que pretende servir como dispositivo para qualificar o registro, produção e uso de informação na produção do cuidado em atenção básica.

Cada um desses dispositivos da política foi sendo produzido e incentivado a partir de mecanismos de financiamento específicos. Essa versão da política nacional de atenção básica intensifica a relação de indução financeira e o papel controlador do Ministério da Saúde em relação aos outros entes federados.

Apesar de haver críticas crescentes à homogeneização das práticas e arranjos diante de contextos tão heterogêneos Brasil afora, da sobrecarga que os mecanismos de controle têm implicado para as equipes, da centralidade do médico nas práticas instituídas, da dificuldade de manejo dos agravos não transmissíveis, entre outros, não se vêem sinais de ampliação do debate por parte dos gestores em geral ou de pistas para mudanças por parte do Ministério. Ao longo desta análise da política, já apresentei algumas observações críticas. 0 processo de construção desta política foi disputado inicialmente, com muitas experimentações municipais e proposições acadêmicas, mas a partir da definição da saúde da família como arranjo preferencial houve um silenciamento do debate em torno de arranjos distintos ou proposições alternativas.

Havia muito em jogo: a necessidade de universalizar o acesso, de fazer o SUS existir em todos os municípios brasileiros. Havia disputa entre cesta básica e universalidade/integralidade. Disputa entre apostas: no trabalho vivo e na criatividade dos trabalhadores ou no trabalho morto (padronização, protocolização) e no controle de seu trabalho. Disputas em relação ao conceito de saúde e ao lugar da clínica, da epidemiologia, do cuidado dentro dele. Disputas 
em relação ao lugar de gestores, trabalhadores e usuários nessa produção. Disputa entre o reconhecimento da singularidade da produção das existências e dos modos de vivenciar os sofrimentos e agravos entre a afirmação das regularidades a partir dos processos biológicos e da determinação social do processo saúde-doença.

Disputa entre atenção básica potente e SUS de pobre para pobre. Disputa em relação ao papel dos três entes federados na formulação, financiamento e efetivação da atenção básica. Corporação médica disputando manutenção do modelo médico centrado e médico hegemônico. Governamentalidade neoliberal atravessando corações e mentes e fortalecendo modelo disciplinarizador da vida, culpabilizando usuários por sua "rebeldia" e seus problemas de saúde. Forte atravessamento da indústria farmacêutica e de equipamentos médicos no sentido de modelo de atenção centrado nos procedimentos. Disputas em relação à formação de profissionais de saúde. Omissão em relação a temas complexos, mas candentes, como a violência.

Entre as correntes da reforma sanitária, apesar das divergências, também houve também acordos em relação ao modelo de atenção e a atenção básica: a noção de território; a definição de problema de saúde de maneira mais ampla do que as doenças; o estabelecimento de estratégias para a percepção das desigualdades regionais e microrregionais; a reorganização das práticas de saúde privilegiando uma abordagem interdisciplinar que considera os aspectos individuais e coletivos; a ampliação da percepção dos trabalhadores sobre os usuários enquanto sujeitos que devem ser compreendidos nos seus aspectos biológicos, psíquicos e sociais; a revisão dos conceitos clássicos de hierarquização de serviços; a articulação do setor saúde com os demais setores; e a gestão democratizada com a maior participação dos trabalhadores e usuários nos processos decisórios (BRASIL (A), 2005, p. 84).

Alguns conceitos vêm de longe, como a pirâmide, baseada em Dawson e nas experiências dos outros sistemas universais. Desconexão entre $A B$ e atenção hospitalar e especializada também, embora com agravantes locais. Outros, como a rigidez na definição da área de abrangência e a promoção da saúde trabalhada na perspectiva dos estilos de vida são produto de estratégias biopolíticas de 
controle endossadas acriticamente, principalmente no que diz respeito às ações sobre a população mais pobre.

Retomando a ideia de Ball sobre análise de políticas, vale reconhecer que as políticas são produzidas a partir de seu texto, mas também a partir das disputas de projetos que se materializam em diferentes âmbitos e mobilizando diferentes atores. Como todo mundo faz gestão e produz política, há 32 mil equipes e 32 mil saúdes da família, mas há muito mais regularidades do que singularidades produzidas pelas políticas: tanto pela potência como pela falência dos dispositivos que elas colocaram em marcha.

No que pudemos localizar, as disputas foram as mencionadas. Clara influência de certos segmentos da academia e do movimento sanitário na construção dos elementos componentes da saúde da família (vigilância, programação, promoção). Pequena influência de outros na problematização do arranjo majoritário. Baixa capacidade dos dispositivos e conceitos colocados em marcha para superar o modelo m'dico-hegemõnico.

A pesquisa sobre os bancos de teses, dissertações e artigos pode trazer mais elementos para análise do papel que o campo da saúde coletiva jogou na produção desta política por meio da produção de textos: disputando ou reforçando as formulações vigentes.

Observem a seguir a Linha do Tempo da Política de Atenção Básica do SUS, que apresenta o movimento conceitual da política bem como o conjunto de documentos oficiais identificados e estudados. 


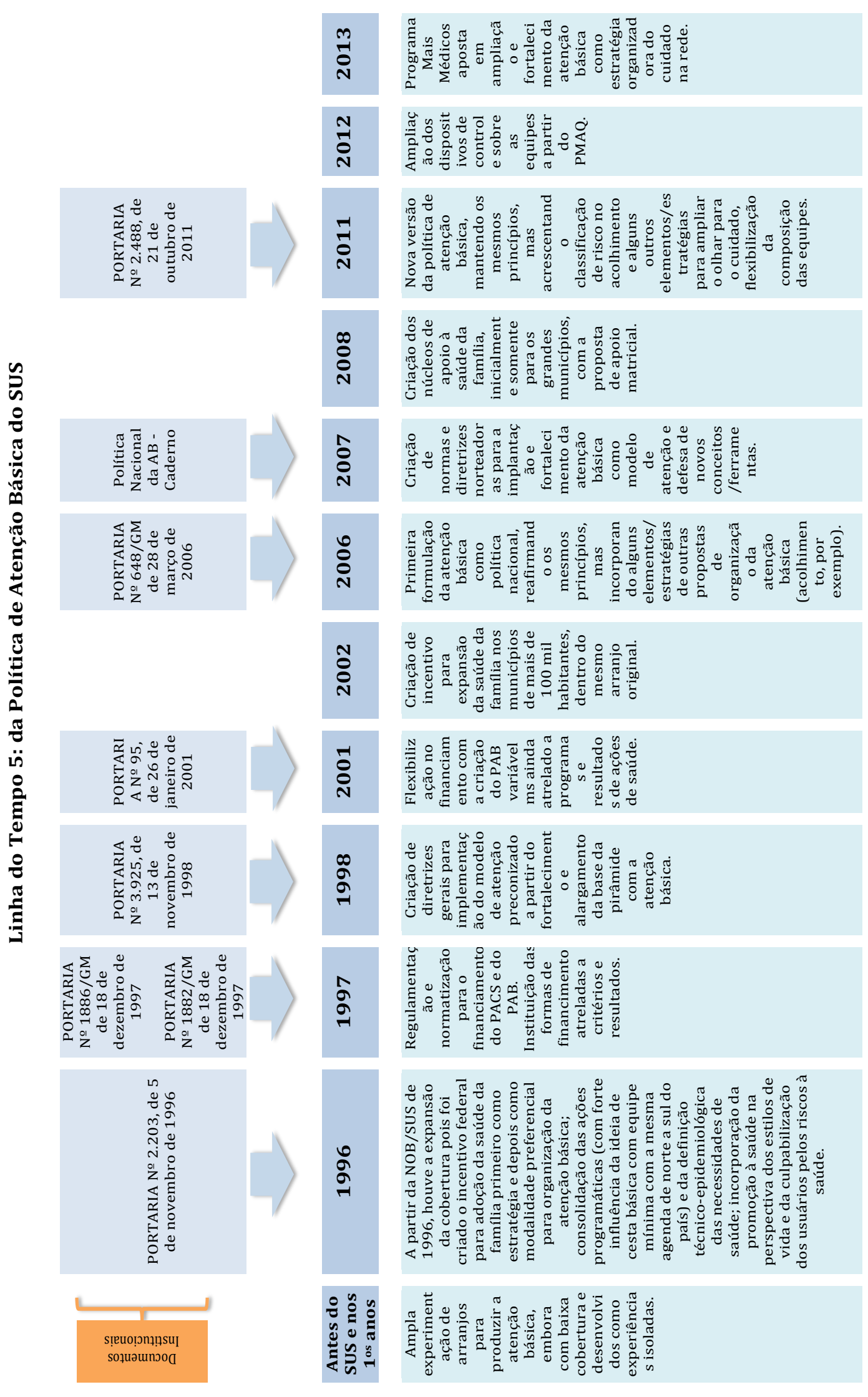




\section{Um olhar direcionado aos textos produzidos sobre a Política de Regionalização e Organização do SUS}

Inicialmente vamos fazer um rápido mapeamento de influências políticas e conceituais na definição dos princípios do SUS, para então examinar a construção da política de regionalização.

Para este exercício analítico, é importante trazer para a cena o contexto político no momento da produção do texto constitucional e nos anos seguintes de construção dos arranjos e proposições para efetivação do sistema.

Na Assembleia Constituinte que marca a saída do país de um período ditatorial que durou 21 anos, as tensões e lutas entre diferentes grupos políticos e movimentos sociais ficou claramente expressa. Garantia constitucional de direitos, sim, que na prática marca um momento de vitória em uma longa batalha, já que foi necessário seguir lutando pela construção de políticas que os efetivassem, de modo heterogêneo e desigual ao longo dos anos, a partir de movimentos intensos de disputa mais ou menos acirrados e capilarizados e a partir de diferentes acumulações teórico-políticas.

No âmbito da saúde, foi possível emplacar o direito cidadão e dever do estado, mas não a criação de um sistema público estatal. Nos anos que antecederam a criação do SUS, foram efetivados vários movimentos políticos no sentido da montagem de uma rede de serviços e também de nichos diversos de formulação de conceitos e propostas que sustentassem a construção de um sistema de saúde. Havia forças políticas organizadas trabalhando nesse sentido e outras que haviam produzido o longo dos anos de ditadura os primeiros arranjos para um sistema privado de saúde. Movimentação intrincada, por que ambos movimentos se efetivavam no cenário vivo de produção da atenção à saúde no país, na rede de serviços real que ia sendo produzida.

As primeiras eleições presidenciais depois do fim da ditadura marcam já uma guinada em relação à orientação político-econômica de produção de país. Segue-se acirramento de disputas entre desregulamentação e efetivação de direitos. E o SUS veio sendo construído nessa contramão da história e intensamente marcado por essa circunstância. 
Do ponto de vista da produção de ideias e conceitos, o Movimento da Reforma Sanitária Brasileira dialogou em muitos aspectos com a Reforma Sanitária Italiana. Para começar pelo movimento em si, como expressão social semelhante, que apresenta como ponto central a luta pelo direito à saúde. Em ambos os países houve mobilização social e política para conquistar direitos. Ambos os sistemas de saúde foram propostos na lógica da seguridade social e trabalhavam com um conceito ampliado de saúde.

A aposta desses dois movimentos de reforma, por sua vez, foi inspirada no sistema de saúde inglês, o National Health System (NHS). Não só por tomarem a saúde como direito cidadão e dever do Estado, mas também porque ambos foram, como o NHS, influenciados pelas proposições contidas no Informe Dawson, de 1920. Nesse documento estão formulados explicitamente os conceitos de regionalização, descentralização, fluxo e regulação do acesso, assim como o conceito de organização da rede de serviços por níveis de atenção. É nesse documento, publicado, logo após a Primeira Grande Guerra Mundial, que se expressa a primeira formulação de um sistema universal. Com base nessas proposições, após a segunda guerra, foi construído o sistema de saúde inglês, referência mundial para sistemas universais de saúde.

No SUS, a proposta de hierarquização entre níveis de atenção materializa a pirâmide e reforça a ideia de complexidade diferenciada entre os serviços de saúde: do primário ao terciário. Do mais simples ao mais complexo. Supõe também uma distribuição regionalizada de oferta, de modo que os serviços primários estejam mais capilarizados, os secundários e terciários crescentemente concentrados, todos articulados entre si por meio da referência e da contrarreferência. Está implícita nessa proposição uma certa racionalidade na disponibilização dos recursos e equipamentos necessários à garantia do acesso universal, que não leva em conta a desigualdade na distribuição da riqueza que é marcante em nosso país. Ou seja, não seria/é/será suficiente a definição técnica da pirâmide para garantir a existência dos serviços na disposição regional suposta para atender as necessidades de saúde da população, também heterogeneamente distribuída. 
No SUS, a ideia de regionalização está articulada à descentralização da gestão e da responsabilidade sanitária entre os entes federados, mas ao contrário da ideia de hierarquia entre serviços, no caso da relação entre União, estados e municípios está definida a autonomia de cada esfera em seu âmbito de atuação, numa tensa combinação.

A participação social, aposta democratizante na construção do sistema e das políticas, tem seu arranjo organizativo atrelado ao das esferas de gestão, o que indica que a descentralização, mais que um princípio organizativo, expressa um arranjo de poder.

Integralidade e equidade, princípios fundamentais do SUS, precisam ser efetivados nesse tenso emaranhado de arranjos e relações entre níveis de atenção, esferas de gestão, relações de poder e distribuição de riquezas.

Os princípios do SUS marcam uma perspectiva de proteção social, na lógica da Seguridade Social, articulando previdência, saúde e assistência social. No entanto, em função da guinada política na produção do país, na regulamentação dos princípios constitucionais, essa articulação não foi sustentada, agregando à construção do sistema importante complexidade - tanto por não haver na mesma intensidade a garantia ou a efetivação de outras políticas sociais fundamentais para a produção da saúde entendida de modo ampliado, como pelas limitações/indefinições relacionadas ao financiamento do sistema.

Diante desse quadro, foram produzidos movimentos setoriais na tentativa de garantir a efetivação do sistema de saúde. Assim foi produzido todo um arcabouço de normas infra legais para nortear a produção das políticas e dos serviços e as relações entre os diferentes atores implicados nesse processo. Somente em 2011, o Decreto Presidencial 7.508/11 regulamentou a Lei Orgânica da Saúde (Lei 8.080/90). Essa condição já é analisadora da construção do SUS como política: na contramão, à margem, o que tem implicações na movimentação dos diferentes atores e em seus movimentos de disputa.

A organização do nosso Estado já apontava movimentos descentralizadores desde 1891, na Constituição que criou a República dos Estados Unidos do Brasil com característica federativa, dividida em 20 estados com grande autonomia 
administrativa (mas que se configurava num federalismo dual: SP e MG, oligarquias que dominavam o poder decisório).

Em 1934, houve a expansão de relações intergovernamentais, com disponibilização de recursos e assistência técnica às unidades subnacionais, com a possibilidade de arrecadação local para os municípios. Em 1934 foi lançada uma nova Constituição que define um novo centralismo político-administrativo. Em 1937, com o golpe de Vargas, o Brasil viveu uma ditadura política, marcada pelo ideário de "centralização do poder para desenvolver a nação".

A volta do federalismo aconteceu em 1946, numa nova Constituição de carácter extremamente municipalista, que incluiu a tributação no pacote de competências dos municípios, promovendo a distribuição dos recursos para os municípios sem mecanismo de equalização fiscal.

Em 1953, foi criado o Ministério da Saúde que se ocupou, principalmente, do desenvolvimento de ações coletivas e de saúde pública. Em 1960 foi criada a Lei Orgânica da Previdência Social, que buscou regulamentar o setor e organizar a seguridade social.

Em 1964, ocorreu o golpe militar no país, que marcou mais uma vez mudanças no processo federativo. A reforma tributária de 1966 centralizou poder político e tributário na esfera federal, retrocedendo nos mecanismos redistributivos já existentes. No entanto, houve um avanço relativo a distribuição tributária com a implantação do primeiro sistema de transferência intergovernamental por fundos de participação, que oportunizou uma maior equalização fiscal pelos critérios de distribuição adotados (população e renda per capita). Esses novos arranjos modificaram um pouco a organização do Estado e foram marcados por disputas as quais demonstraram que não havia consenso sobre como melhor organizar o Estado, vivia-se um período de ditadura e havia manifestações populares e em diferentes setores do Estado.

0 regime militar, marcado pela disputa de interesses entre latifundiários e industriais com o restante da população, deflagrou uma época de regulação rígida do Estado, marcada por um processo de modernização e desenvolvimento, chamado de "milagre econômico". 
Após um período de intensas lutas e o fim da ditadura military, em 1985, José Sarney convocou a Assembléia Nacional Constituinte .

A Constituição Federal de 1988, finalmente, redefiniu o desenho federativo do país e estabeleceu responsabilidades para os entes federados e, apesar de reforçar o movimento descentralizatório, reforçando o papel dos municípios, e aumentando as transferências de recursos federais, ainda não considerou a diversidade regional e não avançou na equalização fiscal, pois não institucionalizou mecanismos de relações intergovernamentais.

O movimento Constituinte apresentou uma tendência para adoção de regras uniformes a todas as unidades subnacionais, com o discurso de que "o poder para ser efetivo deve ser dividido" apesar de haver grande diversidade nas capacidades de governo das unidades subnacionais, seja do ponto de vista financeiro, técnico e de gestão existentes. Portanto, com esse desenho federativo do Brasil, os municípios ganharam mais autonomia política, e foram configurados múltiplos centros de poder. Conformou-se um sistema complexo de dependência política e financeira entre as esferas de governo.

Ao mesmo tempo, a Constituição apresentou uma proposta de recentralização de recursos fiscais em nome da política macroeconômica, mas com a instituição de novos critérios para a repartição de receitas entre união, estados e municípios. Ou seja, houve um movimento descentralizador na constituinte, com direção única em cada esfera de governo (Art. 196 da Constituição Federal; diretriz 1), mas o resultado foi uma descentralização aos pedaços, apesar da descentralização ter sido definida no texto e no discurso. É claro que somente se configurou assim por conta das muitas disputas de interesses.

A Constituição de 1988 garantiu, segundo seu artigo 196, que "a saúde é um direito de todos e um dever do Estado, garantido mediante políticas sociais e econômicas que visem à redução do risco de doenças e de outros agravos e ao acesso universal e igualitário às ações e serviços para a sua promoção, proteção e recuperação". Juntamente com o amparo legal da saúde, foram incorporados os princípios de universalidade, eqüidade e integralidade, caracterizando-a como política pública.

Ficou definido que competiria aos municípios prestar, com a cooperação técnica e 
financeira da União e do Estado, serviços de atendimento à saúde da população, contudo, o processo de construção do sistema de saúde não foi tão linear.

Depois da constituição promulgada, nas eleições presidenciais, vence um governo que se opunha a boa parte das deliberações constituintes.

Em função disso, o Governo Collor atrasou a regulamentação da Reforma Sanitária, que só ocorreu no final de 1990, com a Lei 8.080 (Lei Orgânica da Saúde), de 19 de setembro de 1990, que prevê no seu artigo 4º que o Sistema Único de Saúde (SUS) é "o conjunto de ações e serviços de saúde, prestados por órgãos e instituições públicas federais, estaduais e municipais, da Administração direta e indireta e das fundações mantidas pelo Poder Público (...)".

Assegura, no artigo 7ํㅡ, inciso IX, que um dos seus princípios é a "descentralização político-administrativa, com direção única em cada esfera de governo: a) ênfase na descentralização dos serviços para os municípios; b) regionalização e hierarquização da rede de serviços de saúde".

Define que um de seus objetivos, segundo a artigo 5ํㅜ, inciso III, é "a assistência às pessoas por intermédio de ações de promoção, proteção e recuperação da saúde, com a realização integrada das ações assistenciais e das atividades preventivas", enfim, é essa a lei que destaca os princípios operacionais e organizativos do SUS.

Já a Lei 8.142, de 28 de dezembro de 1990, dispõe sobre a participação da comunidade na gestão do SUS e sobre as transferências intergovernais de recursos financeiros na área da saúde e dá outras providências", enfatizando a importância da Conferência de Saúde e do Conselho de Saúde.

Esse referencial legal definiu grandes diretrizes operacionais para o funcionamento do SUS contudo, não houve, por muito tempo, nenhuma regulamentação dessas disposições gerais.

Pensando no ciclo de políticas de Ball, a não regulamentação pode ser reconhecida como um modo de produzir textos: por omissão e imprecisão. Por isso mesmo, as forças interessadas na efetivação do SUS passaram a operar no plano infralegal, definindo normas para a implementação do sistema e tomando as providências necessárias para sua configuração. 
O Instituto Nacional de Assistência Médica da Previdência Social (INAMPS) foi vinculado ao Ministério da Saúde em março de 1990. Nesse mesmo ano, a Fundação Nacional da Saúde foi criada e os Escritórios Regionais do INAMPS e os Serviços Locais de Medicina Social foram extintos. O Ministério da Saúde foi reestruturado e o SUS foi formalmente implantado com a criação do Departamento do SUS, subordinado à Secretaria Nacional de Assistência à Saúde. Esse momento marcou o processo de transição do INAMPS para o SUS, de um sistema de saúde previdenciário para um sistema de saúde universalizante.

Em Junho de 1990, o Ministério da Saúde começou a criar mecanismos de controle e autorizou a implantação do Sistema de Informações Hospitalares do SUS (SIH-SUS) e do Sistema de Informações Ambulatoriais do SUS (SIA-SUS). O SIH-SUS se apoiou no Sistema de Atenção Médico-Hospitalar da Previdência Social (SAMHPS) e em seu instrumento de a Autorização de Internação Hospitalar (AIH).

Existia uma herança de grandes hospitais privados e filantrópicos que atendiam à população previdenciária, que precisavam seguir prestando serviços ao sistema, sendo financiados e incorporados a uma lógica universalizante.

Como parte desse processo houve uma concentração da atenção dos gestores do SUS para enfrentar esse desafio, concentrando a atenção para a média e alta complexidade, especialmente para o cuidado especializado e hospitalar. Nesse momento, o debate sobre a atenção básica não emplacava espaço na agenda política. Em Agosto de 1990, ocorreu a universalização da tabela de valores a serem pagos para os procedimentos realizados. Logo após, em Dezembro de 1990, o Ministério delegou ao INAMPS, por meio de da Portaria GM 1.481 de 31 de dezembro de 1990, a tarefa de implantar a nova política de financiamento do SUS para 1991, por meio de da NOB - SUS 1/91.

Houve, então, um movimento intenso de redefinição dos serviços e da organização do sistema de saúde. Essa transição do INAMPS para o SUS foi complexa, não só porque mudavam os paradigmas organizativos e da lógica do mercado sobre o setor saúde, mas também porque ainda estava indefinido o processo de como os serviços já existentes iriam passar a integrar o SUS com suas novas diretrizes. Enfim, foi um 
momento complexo e de profundos movimentos de mudança mas que precisavam ser melhor definidos e regulamentados.

Em 1991, a NOB - SUS 1/91 foi publicada e tratou de fornecer uma base para o gerenciamento dos serviços e ações de saúde e para operacionalizar a implantação dessa nova política de financiamento, abrangendo as atividades ambulatoriais e hospitalares, o custeio do INAMPS e de Programas Especiais de Saúde, além dos recursos existentes para investimentos.

Ela recebeu muitas críticas por estabelecer mecanismos convencionais para o repasse de recursos e por ser centralizadora, apesar de aparentemente apoiar a descentralização, reforçando o poder municipal. No entanto, os municípios ficaram caracterizados somente como gerentes de unidades, tratados como prestadores de serviço.

As tranferências de recursos tinham que ser negociadas caso a caso e foi criada a unidade de cobertura ambulatorial (UCA) para que esses tipos de procedimentos fossem pagos diretamente a hospitais e ambulatórios.

Por causa das críticas, a Resolução do INAMPS nº 273, de 17 de julho de 1991, modifica a norma, considerando as propostas de diferentes segmentos da sociedade organizada que atuam na área da saúde.

Vale destacar as contradições entre o texto, o discurso e a ação. Os gestores do SUS herdaram uma máquina de produção hospitalar, uma carta de intenções de um sistema universal e integral e uma nova estrutura estatal. Além disso, foram cercados por atores com distintos interesses.

A realidade política e institucional do SUS mudou e os papéis e poderes das secretarias municipais e estaduais da saúde assim como do Ministério da Saúde foram revisados. Especialmente o CONASEMS se apresentou como um ator de muita relevância nesse espaço de disputa.

No momento conturbado pelo qual passava o país, o Movimento Sanitário pressionou e exigiu a realização da IX Conferência Nacional de Saúde, que deveria ter ocorrido dois anos antes, apoiada somente pelo Ministério da Saúde e pelo Conselho Nacional de Saúde. Realizada entre 9 e 14 de agosto de 1992, a conferência teve como tema central "Saúde: A Municipalização é o Caminho", indicando a 
vontade e força acumulados pelos defensores do SUS para que fosse completado o processo descentralizador das ações e serviços de saúde.

Em fins de 1992, diretrizes são formuladas pelo Grupo Especial de Descentralização do Ministério da Saúde, acentuando a presença do projeto municipalista. Ao mesmo tempo, no entanto, o novo cenário delimitou uma escassa existência de mecanismos de coordenação e cooperação intergovernamentais, tanto vertical como horizontal para apoiarem a integração entre as esferas de gestão, acentuando esse afastamento do estado na mediação e produção da política de saúde nos territórios.

O governo mudou novamente e assumiu a gestão da saúde um grupo técnicopolítico do Movimento Sanitário que tinha o compromisso com o SUS. Outra norma, então, é publicada, a NOB - SUS 1/93, de maio de 1993, com o título de "A Ousadia de Cumprir e Fazer Cumprir a Lei".

Essa norma teve como objetivo "disciplinar o processo de descentralização de gestão das ações e serviços de saúde na perspectiva de construção do Sistema Único de Saúde" (introdução da NOB - SUS 1/93), regulando o processo de descentralização das ações e serviços de saúde de forma gradativa devido a sua complexidade.

O conceito de unicidade do sistema de saúde preconizado na legislação não deve ser entendido como forma única de organização em todo o território nacional. É preciso levar em consideração as enormes desigualdades identificadas no país, sejam elas de natureza cultural, econômica ou social. (...) A expressão ÚNICO de que falam a Constituição e a Lei 8.080 deve ser entendida como um conjunto de elementos de natureza doutrinária ou organizacional, comuns aos diversos modelos ou sistemas de saúde existentes ou que possam vir a existir. Do ponto de vista doutrinário, estaria englobando a universalidade, a eqüidade e a integralidade e, do ponto de vista organizacional, a descentralização, a regionalização e o controle social. (BRASIL, 1993) Fonte: Descentralização das Ações e Serviços de Saúde: a ousadia de cumprir e fazer cumprir a lei - NOB SUS 01/93

Na NOB - SUS 1/93 foram estabelecidos níveis de gestão com diferentes graus de complexidade e responsabilidade, o que auxiliou nas situações de transição da municipalização da gestão. Para os municípios foram criadas três modalidades de autonomia: gestão incipiente, em que o município somente assumia a responsabilidade por algumas ações; gestão parcial; e gestão semi-plena, em que o município assume todas as responsabilidades das ações e serviços de saúde por meio dos recursos repassados do governo federal para o fundo municipal de saúde. 
Isso incluia definições políticas, execução, acompanhamento, controle e avaliação dos serviços no interior de seus territórios. Já para os estados somente designadas duas modalidades: a gestão parcial e a gestão semi-plena.

Com intenção de agilizar esse processo, foram designadas as Comissões Intergestoras e os Conselhos de Saúde para coordenar, gerenciar e controlar a efetivação desse processo de descentralização. Foram criados, então, foros permanentes de negociação e deliberações, assim todas as ações poderiam ser discutidas e pactuadas.

Até esse momento, o governo federal impunha limites nos gastos apenas para os procedimentos ambulatoriais, as internações hospitalares eram reguladas por um limite físico de funcionamento, contudo, com o tempo, ficou claro a inviabilidade de um planejamento do sistema nesses moldes.

Por isso, foram estabelecidos tetos financeiros para os estados e municípios, baseados na série histórica dos gastos. Os tetos dos estados foram discutidos com a Comissão Intergestores Tripartite (CIT) e foram regulados como provisórios para iniciar a descentralização com revisão prevista para 100 dias, o que só ocorreu em 1995.

Os tetos dos municípios foram discutidos e aprovados com as Comissões Intergestores Bipartites (CIB). Porém, o somatório dos municípios não poderia ser maior do que o do estado, por isso, o processo de pactuação deveria ser articulado entre os entes, o que não ocorreu, pelo menos não em todos os estados. Dessa forma, se iniciava o processo de programação pactuada que posteriormente acabou recebendo o nome e o conjunto de normativas da PPI - Programação Pactuada Integrada.

Em 30 de agosto de 1994, o Decreto 1.232 foi aprovado, regulamentando o repasse direto de recursos do Fundo Nacional de Saúde para os Fundos Estaduais, Municipais e do Distrito Federal de Saúde, o chamado repasse "fundo a fundo", esse foi mais um passo importante para a implementação da descentralização do sistema. Assim, muitos municípios foram habilitados e assumiram a condição de gestão semiplena. Aos poucos, o sistema ia tomando uma nova configuração regional e o seu processo de organização ia sendo construído a partir dos consensos possíveis. 
A ação do CONASEMS intensa, militante e de cunho municipalista, foi importante para viabilizar o SUS, especialmente nos grandes municípios, onde havia concentração de serviços. Houve, entretanto dificuldades para os pequenos municípios, que ainda ficaram vinculados ao estado para execução do seu papel de gestor dos serviços de que dependiam.

A regulamentação dos tetos financeiros e dos repasses fundo a fundo baseadas em séries históricas dificultaram a promoção da eqüidade já que se basearam em séries históricas de produção de serviços.

A NOB - SUS 1/96, publicada em 5 de novembro, em anexo a Portaria 2.203, pretendia impulsionar a municipalização apesar das dificuldades referentes ao financiamento do SUS. Previa a construção de um novo pacto federativo para a saúde, revendo a responsabilidade sanitária de cada gestor; reorganizando o modelo assistencial descentralizado; aumentando a porcentagem de repasses fundo a fundo.

Fortaleceu a gestão compartilhada entre as três esferas de pode e para tanto foram criadas Comissões Intergestores Bipartites e Tripartite, como espaços de negociação entre os gestores. Estabeleceu ainda vínculo entre o cidadão e o SUS, por meio de do cadastramento e da criação do cartão SUS-municipal. Além desses objetivos, essa norma foi caracterizada por estabelecer a "direção única em cada nível de governo" (NOB - SUS 1/96) garantindo que as responsabilidades assumidas pelo gestor fossem cumpridas; e por caracterizar os Sistemas Municipais de Saúde como:

(...) a totalidade das ações e serviços de atenção à saúde, voltadas ao atendimento integral de sua população, desenvolvidas em um conjunto de estabelecimentos com seus serviços de saúde, inserido de forma indissociável no SUS e, organizado em uma rede regionalizada e hierarquizada. (NOB - SUS 1/96)

Foi previsto na NOB - SUS 1/96 que as relações entre os municípios devem ser mediadas pelo estado e que as relações entre os estados devem ser mediadas pelo Ministério da Saúde, sendo que o principal instrumento formalizador das relações seria a Programação Pactuada e Integrada (PPI), traduzindo as responsabilidades, os objetivos, as metas, as referências inter municipais, os recursos e os tetos orçamentários e financeiros, em todos os níveis de gestão, assegurando o acesso 
universal por intermédio da relação gestor-gestor. Estabeleceu-se que os níveis estaduais e federal têm o papel redistributivo, visando garantir a eqüidade.

Também previa a transferência da responsabilidade da gestão plena de atenção básica ambulatorial para a maioria dos municípios, garantindo a transferência dos repasses de recursos aos mesmos (PAB: piso ambulatorial básico = $\mathrm{R} \$ 1,00 /$ mês/hab, estabelecido como repasse mensal), além da incorporação de ações da Vigilância Sanitária e de Epidemiologia e Controle de Doenças.

Como já mencionado e discutido anteriormente, também favoreceu a ampliação da cobertura do Programa de Saúde da Família (PSF) e do Programa de Agentes Comunitários (PACS).

Enfim, foi essa norma que estabeleceu novas regras para a gestão do SUS, possibilitou estabelecer formas de organizar as ações e serviços de saúde em busca dos preceitos do sistema, de universalidade, eqüidade e integralidade e atendendo aos princípios que regem o SUS: regionalização e hierarquização, de resolução, de participação dos cidadãos por meio de do controle social, de complementaridade do setor privado e de descentralização, transferindo as responsabilidades com as ações e serviços de saúde entre os vários níveis de governo.

Continuava crítico, entretanto, o problema do financiamento do sistema, já que não havia fontes asseguradas, nem percentuais de investimento definidos. 0 problema foi parcialmente contornado com a aprovação da Contribuição Provisória sobre a Movimentação Financeira (CPMF) que aumentou a alocação de recursos para a saúde.

Em 2000, foi aprovada a Emenda 29/2000, definindo a vinculação, progressiva, de percentuais dos orçamentos municipais e estaduais e consignando um percentual de $5 \%$ do incremento do produto interno bruto, se esse aumentasse de um ano fiscal para outro, pois visava à expansão da alocação para a saúde de recursos fiscais de estados e municípios de forma compulsória.

Infelizmente, essa emenda não foi apoiada pela equipe econômica (nem desse, nem de outras gestões federais) e sua regulamentação foi adiada por mais de dez anos. Mais uma vez, havia um cenário econômico e político desfavorável aos avanços do SUS. 
Em 2001, o Ministério da Saúde publicou a Norma Operacional de Assistência à Saúde (NOAS 1/2001), que propunha instrumentos de regionalização da assistência, conduzidos pelas secretarias estaduais de saúde, procurando produzir outro equilíbrio de forças para a gestão do SUS.

Também foi na NOAS que houve atualização dos critérios de habilitação de estados e municípios com uma ambição de regular a competição entre os municípios, resultando na incorporação de tecnologias mais complexas e de maior custo.

Para os municípios foi proposta a gestão plena de atenção básica ampliada e a gestão plena do sistema municipal. Para os estados, gestão avançada do sistema estadual e gestão plena do sistema estadual.

Além disso, foram definidas áreas mínimas de atuação para os municípios: controle de tuberculose, controle da hipertensão arterial, controle do diabetes melito, eliminação da hanseníase, saúde da criança, saúde da mulher e saúde bucal. O PAB também é transformado nessa NOAS, deixando de ser um repasse automático por causa da população, e criando requisitos para a habilitação dos municípios. Somado a essas mudanças está incluída a criação do PAB fixo e do PAB ampliado, recursos "carimbados" pela União, caracterizando mais uma prática centralizadora no SUS.

A NOAS buscou criar alguns mecanismos de gestão a partir do estabelecimento das relações entre as esferas, contudo, produziu também um retrocesso no financiamento da atenção básica. Assim, a virada do século, para o SUS, trouxe mudanças e desafios a serem superados.

A NOAS 2002 reforçou as exigências sobre as ações de controle, avaliação e auditoria; introduziu o conceito de regulação ligado estritamente ao acesso dos usuários aos serviços de saúde. A partir dessa percepção, surgiu o esforço de caracterizar e qualificar conceito e processos de trabalho atrelados a regulação, como por exemplo a Portaria SAS 423/2002, que tinha por objetivo ratificar as diretrizes da política de "Controle, Avaliação e Regulação" e a Portaria SAS 729/2002, que elegeu indicadores com a função de orientar tanto a elaboração quanto avaliar a implementação de planos de Controle, Regulação e Avaliação de estados e municípios. Esta última foi reforçada com o Pacto de gestão em 2006, que define as diretrizes operacionais do SUS. 
O movimento geral foi o de produção de regras e instrumentos considerados pelos governantes necessários paras operacionalizar o sistema de saúde, mas foram feitas escolhas que limitaram as potencialidades do próprio sistema, do SUS.

Assim, logo em seguida, em 2003, após a vitória de Lula na presidência do Brasil, várias dessas limitações impostas pela NOAS foram revogadas.

Com novos gestores no Ministério, muitos deles participantes do movimento da reforma sanitária, foram produzidas mudanças para a defesa daquele projeto. Muitas mudanças foram feitas para o fortalecimento da atenção básica, já comentadas anteriormente, inclusive recuperando a transferência automática do PAB fixo e incrementando o PAB variável.

Houve também um grande investimento para a reorganização da relação intergestores com a proposta dos Pactos pela Saúde - Pacto pela Vida, Pacto em defesa do SUS e Pacto de Gestão. 0 objetivo desse conjunto de pactuações era contribuir para a reavaliação do papel das instâncias gestoras do sistema, fortalecendo os espaços de pactuação regionalizados e auxiliando na definição das prioridades do SUS, no sentido de fortalecer a regionalização da atenção.

Os Pactos recupervam algumas bandeiras de luta do movimento da reforma sanitária e procuraram dar mais flexibilidade aos instrumentos, fortalecendo a pactuação e articulação intergestores ${ }^{22}$ fundamental para o funcionamento do sistema. Novas regiões de saúde compostas em torno da articulação de Colegiados de Gestão regional eram uma possibilidade de construir uma gestão mais colegiada e solidária. Nova tentativa de desfragmentar a transferência de recursos fundo-afundo, como já comentado na discussão da atenção básica.

Entre os principais ganhos com os Pactos, destacam-se:

- Flexibiliza a forma de habilitação dos estados e municípios de acordo com as potencialidades instaladas (Termos de Compromisso de Gestão);

- Indução do processo de descentralização e regionalização (atrelado às pactuacões de ações e metas regionais - CIB`s regionais);

\footnotetext{
22 Movimento de encontro e produção de acordos, de consensos e de possibilidades de compartilhamento de responsabilidades. Pressupõem diálogo em espaço mobilizador de encontros que tenham mediação para apoiar o processo que em muitos momentos é permeado por interesses e apostas divergentes.
} 
- Diminuição do número de "caixinhas" de carimbos para o repasse financeiro:

- 5 blocos de financiamento: Atenção básica/primária, Atenção de média e alta complexidade, Vigilância em Saúde, Assistência Farmacêutica, Gestão do SUS.

- Contratualização de todos os prestadores de serviços;

- Colocação de todos os leitos e serviços ambulatoriais contratualizados sob regulação;

- Extinção do pagamento dos serviços dos profissionais médicos por meio do código 7.

O Pacto pela Vida traz prioridades que foram destacadas para serem pactuadas entre os gestores do SUS, considerando que os estados/regiões/municípios devem desenvolver as ações necessárias para o cumprimento de metas e objetivos propostos. Tais metas e objetivos visam fortalecer as ações de atenção à saúde nessas áreas identificadas como estratégicas para a melhoria da situação de saúde da população e propõe uma agenda estratégica para adesão dos diferentes níveis gestores.

Pontos importantes do Pacto pela Vida:

- Promoção da Saúde

- Atenção Básica

- Idoso

- MH-Dengue-TB Malária e Influenza

- Mortalidade Infantil e Materna

- CA mama e colo

- Saúde do Trabalhador

- Saúde Mental

- Reabilitação

O Pacto em Defesa do SUS pretende reafirmar o compromisso dos gestores com a consolidação da Reforma Sanitária Brasileira e com os princípios do SUS, desenvolvendo ações para qualificar e assegurar o SUS como política pública.

Pontos importantes do Pacto em Defesa do SUS:

- Repolitização da saúde (Reforma Sanitária)

- Promoção da Cidadania (Direito à Saúde) 
- Garantia do financiamento de acordo com as necessidades do sistema

- Carta dos Direitos dos Usuários

- Relação com os movimentos sociais

- Aprovação dos Orçamentos 2006

- PLC-01-03 e REG.EC 29

O Pacto de Gestão em sua proposta estabelece grandes diretrizes às esferas gestoras para implementação das políticas de saúde, bem como propõem novos mecanismos e dispositivos de gestão que pretendem superar a fragmentação causada ao longo da implantação do SUS, nas suas tantas normas e legislações que regulam o sistema de saúde brasileiro.

Pontos importantes do Pacto de Gestão:

- Descentralização

- Regionalização

- Financiamento

- Planejamento e PPI

- Regulação

- Participação Social

- Gestão do Trabalho e Educação na Saúde

- Implantação dos Programas de Saúde Mental, CEO, SAMU, CEREST e outros estratégicos

Os principais instrumentos de planejamento da Regionalização são: Plano Diretor da Regionalização; Plano Diretor de Investimentos; e Programação Pactuada e Integrada da Atenção. O Plano Diretor da Regionalização deveria expressar o desenho final do processo de identificação e reconhecimento das regiões de saúde, em suas diferentes formas, nas Unidades Federadas, objetivando a garantia do acesso, a promoção da equidade, a garantia da integralidade da atenção, a qualificação do processo de descentralização e a racionalização de gastos e otimização de recursos.

Ainda, definido no texto do pacto, a Programação Pactuada e Integrada (PPI) da Assistência à Saúde é um processo por meio do qual seriam definidas e quantificadas as ações de saúde para a população residente em cada território, bem 
como efetuados os pactos intergestores para garantia de acesso da população aos serviços de saúde. (Fonte: Diretrizes para a PPI da Assistência, MS, 2006)

O PDR é o instrumento que aponta a necessidade de investimentos em cada região de saúde, de acordo com o PDR visando garantir a integralidade do cuidado para toda população de abrangência da região recortada. Vai orientar os investimentos na qualificação e expansão da rede assistencial nas diversas regiões.

Entretanto, no segundo mandato de Lula, a nova gestão do Ministério da Saúde abandonou o investimento na politização das relações intergestores, abandonou a aposta de produção solidária do SUS e implementou apenas o plano burocrático do Pacto.

Mais recentemente, o Decreto Presidencial No 7.508, de 2011, regulamenta a Lei no 8.080 para dispor sobre a organização do Sistema Único de Saúde - SUS, o planejamento da saúde, a assistência à saúde e a articulação interfederativa ${ }^{23}$, e dá outras providências. Esse Decreto Presidencial, finalmente, regulamenta vários aspectos das leis orgânicas da saúde e do próprio texto constitucional.

Ele define o conceito de Região de Saúde como o espaço geográfico contínuo constituído por agrupamentos de Municípios limítrofes, delimitado a partir de identidades culturais, econômicas e sociais e de redes de comunicação e infraestrutura de transportes compartilhados, com a finalidade de integrar a organização, o planejamento e a execução de ações e serviços de saúde. Define que as portas de entrada são os serviços de atendimento inicial à saúde do usuário no SUS.

O Mapa da Saúde é definido pelo conceito de descrição geográfica da distribuição de recursos humanos e de ações e serviços de saúde ofertados pelo SUS e pela iniciativa privada, considerando-se a capacidade instalada existente, os investimentos e o desempenho aferido a partir dos indicadores de saúde do sistema.

Outro conceito melhor definido é o de Rede de Atenção à Saúde, trabalhado como um conjunto de ações e serviços de saúde articulados em níveis de complexidade crescente, com a finalidade de garantir a integralidade da assistência à saúde.

\footnotetext{
${ }^{23}$ Movimento de encontro entre os gestores dos diferentes entes federados para produção de acordos e de produções articuladas com vistas a promover a integração articulada das redes regionalizadas de atenção à saúde.
} 
Assim, as regiões de saúde serão referência para os processos organizativos do SUS, entre elas, a programação das ações e serviços de saúde atrelada a programação financeira. Da mesma forma, as regiões de saúde deverão definir seus limites geográficos, a população usuária das ações e serviços de saúde, o roll de ações e serviços que serão ofertados na região, a as respectivas responsabilidades, critérios de acessibilidade e escala para conformação dos serviços.

No âmbito dessa nova proposta, agora a Programação Geral de Ações e Serviços de Saúde deverá contemplar o conjunto da programação a partir da RENASES e comporá parte importante do Contrato Organizativo de Ação Público (COAP), que formalizará o processo de negociação que deverá ser feito para efetivar a contratualização ${ }^{24}$. Ou seja, a "nova" PPI será mais abrangente, terá um papel mais estratégico no planejamento dos sistemas de saúde regionalizados organizados a partir da constituição das redes de atenção à saúde e deverão contemplar o conjunto de fontes de financiamento que sustentam o funcionamento do SUS, trazendo mais transparência nos três níveis de gestão do SUS em como estão sendo aplicados os recursos da saúde.

Embora dê legalidade a várias definições do SUS até então operadas de modo infralegal, o decreto desloca o tom das relações intergestores para a contratualização formal por meio de metas, subestimando as disputas e tensões políticas envolvidas na produção do sistema. Tanto é, que o COAP praticamente não saiu do papel.

Ball nos traz uma reflexão importante sobre como esse processo de construção da política acontece. Os textos relacionados à descentralização e relação intergestores, processo político crítico para a construção do SUS, oscilaram em suas apostas.

Embora as palavras descentralização e regionalização estivessem sempre presentes, cada texto pendia para um lado: mais municipalista, mais fortalecedor da esfera estadual, ora centralizador em torno do Ministério da Saúde como formulador de políticas, ora fortalecedor de dispositivos para a construção compartilhada. Essa

\footnotetext{
${ }^{24}$ Processo de formalização de contrato entre entes federados de forma negociada a partir de critérios previamente definidos para apoiar a elaboração do desenho de rede regional, apoiada pelo conceito de programação do sistema e regulação do acesso para operarem as redes de atenção à saúde a partir da organização hierarquizada do sistema.
} 
orientação fica mais clara a partir da análise dos dispositivos que cada norma colocou em movimento.

Não regulamentar o SUS é um modo de produzir texto de política. Regulamentar numa lógica muito mais contratualizada do que pactuada é um modo de produzir texto de política. Declarar a autonomia de cada esfera de gestão, mas não produzir meios para que essa autonomia se efetive é um modo de produzir texto de política. Defender a construção de regiões, mas não produzir meios para mediar conflitos e desequilíbrios intrarregionais é um modo de produzir texto de política.

Enfim, cada norma propôs dispositivos para operar a diretriz da regionalização e da descentralização de uma forma, sem continuidade e sem apoio para que a gestão local fosse efetivamente fortalecida. Gestão frágil tem baixa capacidade regulatória e isso interfere fortemente na dinâmica pública-privada que atravessa intensamente o SUS e que é constitutiva das distintas dinâmicas regionais!

O próprio modelo de financiamento do sistema não favorece grandes processos inventivos de autonomia das gestões municipais do sistema. Então, mesmo que os textos da política expressassem essa diretriz, o dispositivo financiamento não operava no mesmo sentido.

Não há racionalidade técnica suficiente para superar problemas políticos e a disputa de projetos econômicos! A única proposta que encampou a política na intensidade necessária foi o Pacto, mas não houve sustentação política tempo suficiente para produzir os dispositivos necessários para sua efetivação.

Num cenário tão complexo e de disputas tão intrincadas, parece quase ingênua a aposta de que a atenção básica pudesse operar como ordenadora do sistema!!! Além disso, a produção micropolítica das relações que constituem todas as esferas de gestão e as relações entre elas também nunca entraram em consideração nesse tipo de Normas Organizativas (com exeção potencialmentedo pacto), que supõem sempre uma homogeneidade e a suficiência das normas e dos incentivos financeiros. Assim, parece haver um desencontro fatal entre a proposta organizativa do sistema, a proposta assistencial e ambição antihegemônica do sistema.

Como podemos pensar a organização das redes regionalizadas compostas por municípios com autonomia de gestão, mas sem recursos disponíveis para garantir a 
integralidade do cuidado? Como garantir a integralidade para além dos territórios geopolíticos dos municípios num arranjo federativo que pressupõe essa autonomia dos entes? E como produzir o cuidado em rede, considerando esse cenário, a partir de movimentos de articulação e pactuação entre diferentes âmbitos gestores? Sendo assim, observa-se que existe uma pretensão de construção de uma política de organização regionalizada do sistema, mas o contexto e o modelo assistencial previsto não dialogam entre si.

Não foi possível até o momento superar a grande fragilidade na produção política do próprio sistema, minada ainda mais pela construção do gestor federal como o grande formulador que utiliza os recursos financeiros como indutores dos movimentos de todos os demais atores: gestores estaduais, municipais, trabalhadores e usuários.

Abaixo está anexada a Linha do Tempo da Política de Regionalização e Organização do SUS que sintetiza de forma gráfica o movimento conceitual observado no período de desenvolvimento da política bem como o conjunto de documentos oficiais estudados. 


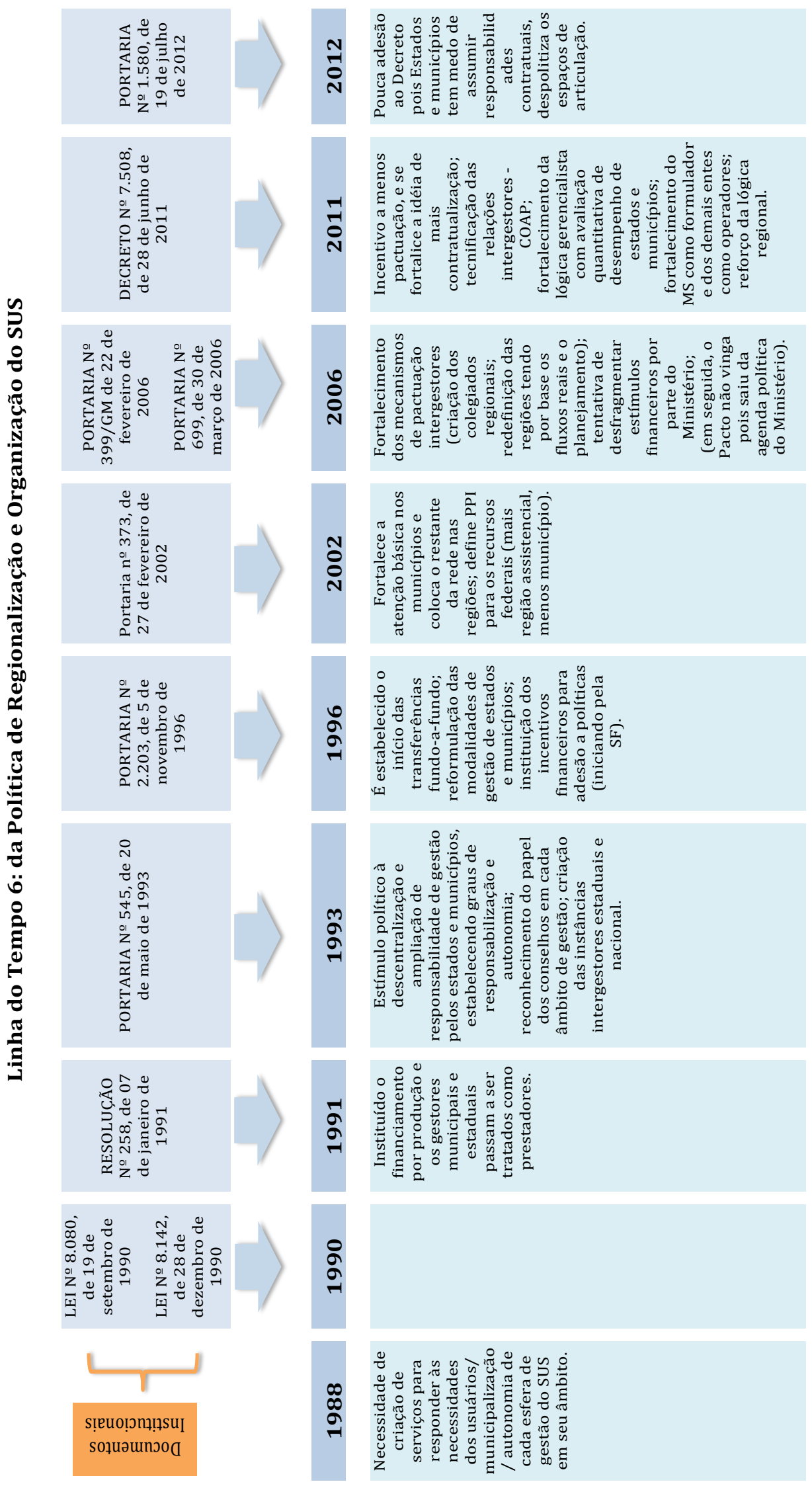




\section{Um olhar direcionado aos textos produzidos sobre a Política de Educação na Saúde}

Pelo menos, a partir da segunda metade do século 20, discutia-se em diferentes espaços internacionais a importância de reorientar a formação profissional em saúde com o objetivo de adequa-la às necessidades dos serviços e dos sistemas de saúde.

A partir da Conferência de Alma Ata e das metas do milênio (dentro da saúde para todos no ano 2000) muitos países passaram a repensar os modelos de formação dos profissionais de saúde.

Além disso, em todos os movimentos de reforma e reorientação dos sistemas de saúde identificava-se como questão crítica o envolvimento dos trabalhadores na produção de novas ordens. A principal estratégia adotada até então eram as capacitações, com resultados muito limitados.

Em 1985, uma equipe do Programa de Desenvolvimento de Recursos Humanos (PDRH-OPAS) da OPAS propõe o conceito de educação permanente alternativamente às capacitações. Por um llado, a educação permanente como estratégia participativa para identificação de problemas e necessidades de aprendizagem. Por outro, a educação permanente como processo coletivo de negociação, reconhecendo que todos governam e todos disputam projetos na efetivação do trabalho em saúde. (Feuerwerker e Merhy, 2013)

No Brasil, as primeiras iniciativas, ainda durante a ditadura, que endereçavam a necessária articulação entre a formação, a gestão e o trabalho foram os projetos de integração docente-assistencial do final dos anos 70 e início dos anos 80.

Em 1986, além da realização da $8^{\text {a }}$ Conferência Nacional de Saúde, foi realizada a $1^{\text {a }}$ Conferência Nacional de Recursos Humanos. A partir dos debates e deliberações de ambas, produziu-se acordo em torno da necessidade de sintonizar a formação de recursos humanos ${ }^{25}$ ao conjunto de conceitos-princípios da reforma sanitaria. A formação era reconhecida como um significativo território de disputa em relação ao modelo de atenção.

${ }^{25}$ A expressão recursos humanos é uma Nomenclatura utilizada para definir o papel dos trabalhadores dentro do sistema de saúde. São considerados recursos, algo que não tem função ativa ou protagonista, é considerado somente um operador do sistema/serviço. 
No início da década de 1980, a partir de um acordo entre Ministério da Saúde, da Educação e da Previdência e Assistência Social, o Projeto de Formação em Larga Escala de Pessoal de Nível Médio foi formalizado pela Portaria Interministerial no 5 , de 11 de março de 1980. Seu objetivo principal era qualificar profissionalmente os trabalhadores de nível médio e elementar que atuavam nos serviços de saúde a partir de metodologias participativas baseadas nas formulações de Paulo Freire. Tal metodologia preconiza a problematização como ponto de partida para a educação de adultos pois permite o diálogo com a realidade concreta, com o cotidiano dos participantes, e coloca a educação como prática de liberdade já que fomenta o olhar crítico para a realidade. (Gryschek, et. al., 2000)

O Projeto Larga Escala foi uma iniciativa relevante tanto na proposta como no alcance, e, sua proposta aproximava a formação dos espaços do serviço. Os profisisonais de saúde dos serviços assumiram o papel de instrutores/supervisores. (Gryschek, et. al., 2000)

Essa iniciativa assumiu a educação como prática transformadora, que se configurou como alternativa potente para a formação profissional de trabalhadores que estavam inseridos nos serviços mas que não possuíam formação específica.

O Larga Escala foi desenvolvido até a regulamentação da atual Lei de Diretrizes e Bases da Educação Nacional (LDB), que extinguiu os cursos supletivos em 1996, incluindo esse programa. De toda forma, foi uma iniciativa muito relevante, no período, pois já trabalhava com algumas questões educacionais interessantes e, que, posteriormente, e até hoje, são debatidas. (Bagnato, 2009)

Como resultado do reconhecimento da importância da sintonia entre formação e políticas de saúde, o Art. 200 da Constituição Federal define como responsabilidade do SUS o ordenamento da formação profissional na área da saúde.

No entanto, como tantos outros, esse artigo nunca foi regulamentado, deixando espaço aberto para uma disputa entre Ministérios da Saúde e da Educação em torno da formulação de políticas para formação. Mas antes da disputa (início do governo Lula), houve foi um vazio de políticas na área.

Foi em função de uma intensa mobilização de docentes e estudantes de graduação, organizados em diferentes movimentos uni e interprofissionais, que o tema da 
necessária aproximação da formação aos princípios e políticas do SUS entrou para a agenda política.

Durante a década de 90 houve a constituição da Comissão Nacional Interinstitucional de Avaliação do Ensino Médico (CINAEM), processo de mobilização que buscou usar a avaliação como estratégia para a produção de mudanças/ou projetos de mudança para a educação médica. Essa agenda mobilizou diversos atores incluindo uma militância importante do movimento estudantil da medicina. A Rede Unida, por meio de de seu atores institucionais, participou, ativamente, desse processo.

A Rede Unida foi constituída a partir da articulação de vários projetos de mudança em diferentes profissões da saúde em torno do que antes tinha sido a Rede IDA (rede de projetos de integração docente-assistencial). Dentre esses projetos/movimentos vale citar os projetos UNI (Programa UNI: união com a comunidade, uma nova iniciativa em educação para os profissionais de saúde), financiados pela Fundação Kellogg em onze países da América Latina de 1991 a 2004. A aposta principal era produzir mudanças na formação de profissionais de saúde a partir da articulação entre universidades, serviços de saúde e comunidade. (FEUERWERKER, 1998 e 2002)

Havia também o movimento da enfermagem, organizada em torno da Associação Brasileira de Enfermagem (ABEn), que estimulou e formulou novas propostas e experiências de formação.

Todos esses atores, articulados aos gestores municipais (Conasems) e ao Conselho Nacional de Saúde jogaram papel fundamental na formulação das novas diretrizes curriculares para a a área da saúde (a partir de um edital lançado pelo MEC, os movimentos produziram uma arena participativa), promulgadas a partir de 2001. As diretrizes embora nunca implementadas pelo MEC, serviram de referência para os movimentos que se seguiram (FEUERWERKER, 2002).

Outra articulação importante, mas envolvendo trabalhadores sindicalizados, foi o processo de construção da Norma Operacional Básica de Recursos Humanos do SUS (NOB/RH SUS). Esse debate se prolongou por alguns anos no Conselho Nacional de Saúde, e, depois de concluída sua formulação, praticamente não foi utilizada. Isso 
pois, no ano seguinte a sua finalização, o Ministério da Saúde iniciou o processo de debate e construção de uma nova política para a gestão do trabalho e da educação na saúde. Como acúmulo desse conjunto de debates, no Documento Princípios e Diretrizes para a NOB/RH SUS é conceituada a Educação Permanente ou Continuada 26 como:

constitui-se no processo de permanente a aquisição de informações pelo trabalhador, de todo e qualquer conhecimento, por meio de escolarização formal ou não formal, de vivências, de experiências laborais e emocionais, no âmbito institucional ou fora dele. Compreende a formação profissional, a qualificação, a requalificação, a especialização, o aperfeiçoamento e a atualização. Tem o objetivo de melhorar e ampliar a capacidade laboral do trabalhador, em função de suas necessidades individuais, da equipe de trabalho e da instituição em que trabalha. (Princípios e Diretrizes para a NOB/RH-SUS, 2002, pag, 28 e 29).

É possível perceber que nesse conceito havia um foco no desenvolvimento do trabalhador e na agenda do trabalho, da carreira, da saúde ocupacional, etc.

Em 2003, a Comissão Intersetorial de Recursos Humanos do Conselho Nacional de Saúde aprovou a Resolução n ${ }^{\circ}$ 330, em 04 de novembro, definindo que tanto o Documento Princípios e Diretrizes para a NOB/RH SUS, quanto a própria norma seriam os textos orientadores de uma possível Política Nacional de Gestão do Trabalho e Educação em Saúde do SUS. Essa era a construção defendida pelo ator movimento sindical que estava disputando a produção da política.

Diante das tentativas (tensas e conflituosas) de construir processos alternativos de formação, docentes e estudantes identificavam a necessidade de políticas específicas de orientação e apoio para as mudanças.

No Ministério da Educação não havia interlocução nesse sentido. No Ministério da Saúde havia um pouco mais. Foi assim que foi proposto o foi o PROMED (Programa de Incentivo a Mudanças Curriculares nas Escolas Médicas), que tomava as Diretrizes Curriculares da Medicina como base para um program de reorientação da formação médica com ênfase na atenção básica. (FEUERWERKER, 2002)

Ainda no âmbito do Ministério da Saúde é preciso registrar os Pólos de Capacitação

\footnotetext{
${ }^{26}$ Processo de permanente a aquisição de informações pelo trabalhador, de todo e qualquer conhecimento, por meio de escolarização formal ou não formal, de vivências, de experiências laborais e emocionais, no âmbito institucional ou fora dele. Assim conceituada desde NOB-RH/SUS.
} 
em Saúde da Família que cumpriram um papel no desenvolvimento do curso introdutório de Saúde da Família, mas que de algum modo intensificaram o diálogo e as trocas entre instituições formadoras eo SUS.

O Programa de Profissionalização dos Trabalhadores da Área de Enfermagem (Profae) foi um grande programa para qualificação técnica do trabalho de enfermagem; o Programa de Desenvolvimento Gerencial de Unidades Básicas de Saúde (Gerus) apoiou a estruturação da atenção básica.

Também houve o Programa de Interiorização do Trabalho em Saúde (Pits) que buscou ampliar o provimento de medicos e enfermeiros para a atenção básica onde havia vazios assistenciais por falta de profissionais.

Além dessas iniciativas programáticas, houve ainda outros processos de capacitação, mestrados profissionais e cursos de formação de conselheiros. Todos esses processos estavam desarticulados e foram ofertados de forma fragmentada, apesar de expressarem a idéia comum de que a formação e qualificação dos profissionais poderia influenciar na implementação das políticas. (BRASIL, 2005)

Em 2003, com o início do governo Lula, houve uma reestruturação do Ministério da Saúde. Uma das mudanças foi a criação a Secretaria de Gestão do Trabalho e da Educação na Saúde. Esse espaço institucional materializou o reconhecimento por parte do governo de que a agenda da formação, da educação, da gestão do trabalho e da regulação do trabalho em saúde era importante para a disputa do projeto social do sistema universal de saúde.

A Secretaria de Gestão do Trabalho e da Educação na Saúde (SGTES), na época sob a direção da Maria Luiza Jaeger, respeitou, na composição da sua equipe, para a agenda da educação, os movimentos sociais de mudança e convidou para compor sua direção militantes de alguns dos principais movimentos na área.

Depois de intensas negociações e debates com diferentes atoresda gestão, do trabalho, da formação e dos movimentos populares, foi instituída a Política de Formação e Desenvolvimento para o SUS - Política de Educação Permanente em Saúde 27.

${ }^{27}$ Dispositivo de produção da política nos diversos territórios a partir da mobilização, articulação e encontros dos atores desses territórios. A partir das produções políticas locorregionais, é 
No início de 2004, esta política foi publicada pela Portaria 198/GM/MS. Nesse e em outros documentos oficiais estavam expressos conceitos da educação permanente em saúde ${ }^{28}$ como estratégia para formação e desenvolvimento no SUS. , numa perspectiva de aprendizagem pela experiência e de intensificação dos encontros entre instituições formadoras e espaços de gestão e atenção do SUS.

Educação permanente é um conceito em disputa. A política partio reconhecimento de que a educação em saúde apresentava de forma clara a disputa pela atualização e capacitação do fazer em saúde a partir de aportes teóricos, metodológicos, científicos e tecnológicos disponíveis. E propunha, também, a disputa pela produção de relações e encontros a partir das práticas dos agentes no cotidiano de cada equipe, das práticas institucionais e das práticas interinstitucionais, considerando que todas apresentam potência de aprendizado com elas. Assim, a política incentivava a mobilização de atores, de instituições e da própria política de saúde (CECCIM, 2005a e 2005b).

Assim, a política apostav que a educação permanente pode potencializar o diálogo entre o mundo da gestão e o mundo do cuidado, fabricando pontes para esse encontro.

Da mesma forma, apostava que a educação permanente podia ser instrumento de disputa de projeto, quando se considera que projetos participativos são construídos com mais legitimidade e força para serem efetivamente implementados. Por isso, além de política, é uma estratégia de gestão potente para promover mudanças no cotidiano e na produção da saúde.

Especificamente em relação à mudança na graduação, a política propôs encontros e apresentou desafios, procurando tornar possível, de diversas maneiras, a aproximação da formação às necessidades sociais de saúde. Nesse percurso considerava-se necessário superar históricas dicotomias, tais como entre cuidados individuais/coletivos; atividades curativas/preventivas; especialistas/generalistas;

\footnotetext{
descentralizado financiamento para apoiar sua implementação.

${ }^{28} 0$ conceito de educação permanente em saúde aqui assumido foi de estratégia para formação e desenvolvimento dos trabalhadores no SUS. Busca aproximar o mundo da educação e do trabalho, potencializando o encontro entre os serviços de saúde e os processos e espaços formadores. Trouxe o conceito do quadrilátero da formação como conceito-vetor de forma transversal. Pode ser uma importante ferramenta para gestão do trabalho. Deve ser dispositivo para produção da política.
} 
unidades básicas/hospitais, abrindo caminho para a produção de uma nova formulação, que propiciasse a integralidade das práticas de saúde e o compromisso com a defesa da vida (FEUERWERKER, 2012).

As diferentes estratégias propostas cumpriam o objetivo de apoiar e fomentar o engajamento de diferentes atores em diferentes possibilidades de articulação, conhecimento recíproco e experimentação de práticas inovadoras:

- $\quad$ Cooperação entre MS e Fórum de Pró-Reitores de Extensão: apoio para o desenvolvimento do internato regional, com o objetivo de ampliar o compromisso de estudantes, docentes e instituições de ensino superior da área da saúde - durante o processo de formação - com a realidade local, seus problemas e soluções.

- Cooperação entre MS e as diferentes Associações de Ensino, agora organizadas num Fórum das Profissões da Saúde (FNEPAS), para favorecer a ação conjunta das Associações pela adoção da integralidade como eixo da formação em saúde, assim como o trabalho de cada uma delas pela implementação das diretrizes curriculares e pelo fortalecimento dos processos de mudança.

- $\quad$ Cooperação direta entre MS e instituições de ensino superior da área da saúde por meio do apoio técnico e financeiro a projetos e/ou estratégias inovadoras que aproximassem os cursos da área da saúde das necessárias mudanças.

- Cooperação entre o MS e o movimento estudantil com o objetivo de proporcionar aos estudantes momentos de vivência e aproximação com osistema de saúde desde a ótica de sua gestão, consubstanciada nas vivências e estágios na realidade do SUS (VER-SUS).

- Constituição dos Pólos de Educação Permanente em Saúde como um dispositivo de agregação e orientação das diferentes instituições para construção de responsabilidade compartilhada por promover a integralidade da atenção à saúde em uma determinada locorregião. Implicavam uma ampliação substantiva dos atores envolvidos na produção de iniciativas locais, pois reuniam gestores, instituições formadoras, estruturas de controle social, movimentos sociais, hospitais de ensino, serviços de saúde e representação estudantil.

- Formação de Ativadores de Processos de Mudança na graduação das profissões da saúde. Esse foi um curso de especialização para docentes e 
profissionais de saúde vinculados à formação de graduação em saúde. Combinando as experiências acumuladas nas áreas de educação e saúde e, considerando que os processos de mudança institucional são dinâmicos, complexos, intersetoriais e exigem o envolvimento e o apoio dos diversos segmentos internos e externos às instituições de ensino superior, o curso pretendeu valorizar e utilizar as experiências e contextos locais, possibilitando a mobilização das capacidades e competências individuais e coletivas necessárias ao desencadeamento dos processos de mudança desejados. 0 curso foi construído com base na sistematização das experiências de Diferentes movimentos de mudança. Foi construído com a perspectiva de que o ativador estimularia a transformação, mas necessariamente se transformaria; favoreceria processos coletivos de produção e, por isso, também se fabricaria como agente /sujeito na ação. (Brasil, 2005b)

Essas iniciativas partiam do reconhecimento de que a produção de mudanças só se realizaria a partir da disputa dos processos de subjetivação no máximo de espaços possíveis e de diferentes modos. Por isso investiam no apoio ao protagonismo de diferentes tipos de atores sociais - individuais e coletivos e esse era o fundamento da maior parte das estratégias. Pretendia-se assim apoiar a disputa dos projetos ético-políticos em diferentes espaços, construída sempre com base na problematização do cotidiano a partir dos impasses e desconfortos. Essa era a base proposta para o desenvolvimento de construções coletivas, colaborativas e negociadas de novas práticas políticas, pedagógicas e assistenciais.

Foi um período de intensa mobilização - de muitos e diferentes protagonistas, incluindo o movimento estudantil e os movimentos sociais. Algumas iniciativas foram melhor conduzidas, outras enfrentaram mais problemas, mas o efeito de provocar, colocar coletivos em movimento e de intensificar as disputas éticopolíticas foi bastante significativo.

A formação de facilitadores de educação permanente, a formação de ativadores de mudança, o VER-SUS e as Residências Multiprofissionais em Saúde foram potentes dispositivos para fabricar/ativar protagonismo político, ou seja, para produzir atores necessários à disputa ético-política vital para a efetivação do SUS. Até hoje, sete anos passados, nos mais diferentes cenários, os efeitos dessa fabricação ainda 
podem ser percebidos - novos gestores, novos professores nas graduações da área da saúde, uma leva de profissionais que disputa a produção do cuidado no cotidiano das unidades de saúde. E uma importante mobilização dos movimentos populares que se materializa na Tenda Paulo Freire em diferentes encontros e congressos da saúde coletiva, pautando temas decisivos para a produção de territórios existenciais mais ricos, com mais conexões e menos capturas.

Algumas dessas estratégias da agenda política foram dispositivos potentes, tanto para mobilização dos atores, como para um certo protagonismo político na defesa e disputa do projeto em questão que visava uma ação ampla e que disputava o fortalecimento do SUS a partir da pauta da educação na saúde. Podemos destacar as seguintes estratégias como bastante potentes nesse processo: a formação de facilitadores de educação permanente, a formação de ativadores de mudança, o VER-SUS e as Residências Multiprofissionais em Saúde. Foram tão potentes que muitos dos atores mobilizados por essa agenda, nesse período, ainda hoje estão comprometidos com essa disputa e construção nos diferentes locais de inserção e participação social e institucional. (FEUERWERKER, 2014)

Por isso, a afirmação de que "todo mundo faz gestão", inspirada em Matus, que afirma que "todo mundo governa", é muito adequada se considerarmos o desenvolvimento dessa política, especialmente no período 2003-2005. A aposta na micropolítica como agenciadora dos atores para a produção da política em cada território foi fundamental para o processo que foi desencadeado em torno do tema da educação permanente. Com essa aposta, o conceito, literalmente, foi usado como ferramenta da própria produção da política. E tal aposta foi tão potente do ponto de vista do empoderamento do conjunto de atores que muitos ainda hoje se sentem ativados.

Assim, em julho de 2005, quando houve troca de ministro da saúde, toda a equipe da Secretaria foi modificada. A política, enquanto texto oficial, não sofreu grandes modificações, contudo, foram radicalmente transformados os dispositivos propostos, as relações com os diferentes atores e os sentidos produzidos com as mesmas palavras.

Em 2007, foi publicada uma nova Portaria que modificou não somente os modos e a 
dinâmica para transferência de recursos para operação da política, mas também as apostas da política.

Os espaços colegiados locorregionais, anteriormente propostos com o nome de Pólos de Educação Permanente em Saúde, apesar de permanencerem no novo texto da política, com o nome de Comissão Interintitucional de Integração Ensino-Serviço, foram transformados em espaços formais de articulação.

Algumas das ações políticas anteriormente produzidas foram sustentadas pelos atores locais, que resistiram e se ressignificaram nesse período. Foi o caso do VERSUS, em algumas experiências isoladas, das Residências Multiprofissionais em Saúde.

O movimento que mobilizou a agenda das Residências Multiprofissionais em Saúde nesse período foi protagonizado pelos residentes, coordenadores de programas e preceptores, além de alguns outros parceiros empoderados pela política no momento anterior, que apostavam na regulamentação dessa modalidade de formação em serviço. Foram organizados seminários regionais e o primeiro seminário nacional a partir de uma proposta apresentada e disputada por um grupo de residentes junto a nova direção da SGTES. Assim, em 2007, foi ativada a Comissão Nacional de Residência Multiprofissional em Saúde, prevista por lei desde 2005.

Fortes disputas entre esses atores e os Ministérios da Educação e da Saúde fizeram que a regulamentação da residência multiprofissional caminhasse a passos muito lentos.

Os demais dispositivos da nova política29, formalizada pela Portaria 1.996, de 20 de agosto de 2007, também foram apresentados a partir dos novos programas, o PROSAÚDE e o PET-SAÚDE e, mais tarde, a UNASUS.

Os dois primeiros, se apresentam como ações programáticas voltadas para a aproximação da formação, especialmente à Saúde da Família, buscando aproximar as práticas da formação profissional de conceitos como o de redes e da integralidade. O PRO-SAÚDE é um programa que apóia projetos apresentados pelas

${ }^{29}$ Conjunto de normas e critérios definidos para a implementação de ações e projetos de educação permanente nos diferentes estados e regiões do país. 0 financiamento se torna dispositivo da política para estimular sua implementação a partir da mobilização dos atores a partir de 2006. 
IES articuladas com as secretarias municipais de saúde para fomentar mudanças na graduação a partir de atividades integradoras junto aos espaços da Saúde da Família. Tal programa apoiou 265 cursos. O PET-SAÚDE foi denominado como programa de educação pelo trabalho e apoiou, por meio de bolsas para estudantes, docentes e trabalhadores, projetos de promoção à saúde, educação em saúde, vigilância sanitária, saúde mental e fortalecimento da Saúde da Família. Ele envolveu 250 cursos. (FEUERWERKER, 2014)

Tais programas envolveram cerca de $10 \%$ dos cursos, sendo que atualmente há mais de três mil cursos da área da saúde. Somente os cursos de medicina e biomedicina têm a maioria (pouco mais de 50\%) das vagas no setor público; nas demais profissões predominam as vagas em instituições privadas $(80 \%$ na odontologia e $90 \%$ em média para as demais profissões da saúde), que ficam de fora desses programas.

Então, mesmo antes de analisar as estratégias de mudança propostas pelo PróSaúde, dá para afirmar que seu impacto é limitado - do ponto de vista de contribuir para uma significativa mudança no perfil dos profissionais que se formam no Brasil, já que, em função de sua lógica de articulação, tem uma capacidade limitada de envolver instituições de ensino no processo.

Ao pensar políticas para favorecer as mudanças na formação, é importante ter claro que há interlocutores nas escolas interessados e com experiência acumulada na produção de movimentos, que trabalham num cenário complexo, atravessado por múltiplos interesses, em que a governabilidade de iniciativas de mudança tem que ser ativa e delicadamente construída. Há que olhar e dialogar com a agenda real das mudanças para efetivamente colaborar para fortalecê-la.

As diretrizes curriculares nacionais transformaram-se na bandeira geral do movimento de mudanças. É em torno delas que se constroem os cuidadosos arranjos de inovação em direção a uma formação geral, humanista e orientada à integralidade - formação necessária à atuação qualificada dos futuros médicos em qualquer cenário de prática. Mas essa operação não se dá sem conflitos. Ao contrário, ela é disputada palmo a palmo. 
A importância de diversificar cenários de aprendizagem é reconhecida amplamente, mas continua sendo muito difícil levar os professores da área clínica para os cenários extra-hospitalares. É difícil rechaçar a importância da aprendizagem ativa, mas tem cabido às escolas encontrar os meios para promover a formação pedagógica dos professores. Ninguém nega a importância do cuidado integral, mas a invenção das tecnologias para produzi-lo fica por conta de quem quer mudar.

A construção das transformações, portanto, implica na formulação e utilização de um conjunto de estratégias para reflexão e produção de desconfortos, mobilização e construção de tecnologias para responder às novas situações. Não há um elemento isolado que, "incentivado" dê conta de desencadear as mudanças.

Como a agenda de mudanças está construída (em torno da implementação das diretrizes curriculares), como há agentes mobilizados em torno dela, ao invés de "induzir" mudanças, caberia ao Ministério da Saúde apoiar e incentivar iniciativas de mudança; buscar criar cenários políticos favoráveis à sua implementação; ampliar a massa de sujeitos com capacidade de implementá-la a partir dos movimentos existentes; ampliar as interfaces com a educação no sentido de apoiar as mudanças. Fazendo tudo isso de maneira a levar o maior número possível de escolas a participar da transformação, pois mudanças localizadas serão de pouca valia na atual conjuntura de construção do SUS (FEUERWERKER, 2014)

Foram também suspensos os desafios que o encontro de instituições formadoras com a gestão, o trabalho e os movimentos sociais implicava. As instituições de ensino passaram a ser convocadas para propor e realizar cursos de capacitação a distância, vinculados ao projeto da UNASUS. Tais ações massificaram o ensino com foco em conhecimentos específicos replicados para todo o país, não disparando conversas com os diferentes atores para escuta sobre as necessidades de cada território.

Durante aproximadamente seis anos, a política de educação na saúde manteve esse movimento, no entanto, em 2012, com mais uma mudança na gestão do Ministério da Saúde, houve mudanças na agenda.

Com apoio do Departamento de Atenção Básica, para a retomada da iniciativa do Projeto VER-SUS/Brasil no país como um todo. Em janeiro e fevereiro de 2012, o VER-SUS mobilizou mais de 3700 estudantes em 69 municípios do país, de 9 Estados diferentes. Em julho e agosto de 2012, 1640 estudantes em 114 municípios do país, de 11 Estados diferentes. Nos anos seguintes, os números do projeto foram 
aumentando e ele se consolidou como uma importante iniciativa para qualificação da formação dos futuros trabalhadores do SUS, aproximando-os da realidade do sistema de forma crítica e produtiva.

No âmbito da SGTES , com a recomposição da equipe de gestão, três grandes temas voltaram a ser trabalhados: formação em saúde, especialmente dos médicos; residências em saúde; e provimento de profissionais de saúde, especialmente para ampliação e fortalecimento da atenção básica.

Havia um reconhecimento de que, com a implementação do SUS, havia problemas no provimento e fixação de profissionais de saúde, especialmente de médicos. Foram feitos muitos estudos para comprovar tal situação e uma das estratégias sugeridas para superação desses problemas foi o investimento no processo de formação, especialmente médica, e de educação permanente para o conjunto dos trabalhadores do SUS. (Carvalho e Sousa, 2013)

Nesse contexto, foi implementado o Programa de Valorização da Atenção Básica (PROVAB), com o intuito de atender a necessidade de prover médicos para a saúde da família. Algumas experiências internacionais demonstravam a potência da articulação entre trabalho e formação para atrair e fixar temporariamente jovens médicos em locais de difícil acesso. (Carvalho e Sousa, 2013)

O programa envolve um conjunto de ações: Lei no 12.202/2010 amplia os benefícios no FIES aos médicos que atuam na atenção básica em regiões prioritárias para o SUS; Revalida é estratégia de revalidação de diplomas de médicos estrangeiros ou formados em outro país; Portarias do MEC de 2013 ampliam o número de vagas em cursos de medicina que desenvolvem um projeto pedagógico voltado para atender à integralidade do cuidado e as redes de atenção à saúde; Expansão de residências médicas como estratégia de fixação e de formação de médicos para o sistema de saúde; e o PROVAB que teve o objetivo de prover e incentivar profissionais para atuação na atenção básica com apoio de estratégias educacionais em EAD e supervisão pedagógica por meio do Telessaúde e dos programas da UNASUS, bem como o bônus de 10\% nas provas de seleção das residências após sua atuação no programa. (Carvalho e Sousa, 2013) 
A abrangência conquistada foi grande; em 2012 contemplou 950 municípios e mobilizou 4.671 profissionais. No entanto, o programa não apresentou propostas muito atrativas para a categoria médica e esta ainda apresentou baixo percentual de adesão e fixação, pois o número de profissionais necessários era muito maior e as áreas mais desprotegidas continuaram descobertas.

A Educação permanente em saúde também foi retomada. Esse movimento acontece quase como o movimento de furar o muro como Deleuze aponta, onde a prática abre esse espaço/furo na teoria/política/barreira. Foi engendrado e implementado um processo formativo chamado Educação Permanente em Saúde em Movimento. Processo parecido com esse já havia sido construído em 2003 e 2004. 0 curso já mobilizou mais de 4 mil pessoas nas várias regiões de saúde do país. Partindo da ideia da aprendizagem pela experiência, ao invés de indução, a EPS em Movimento propõe reconheceimento dos múltiplos processos de aprendizagem disparados cotidianamente nos encontros entre gestores/trabalhadores/ usuários.

Outra agenda retomada foi a da Residência Multiprofissional. A SGTES tensiona para uma nova composição da CNRMS e para a retomada (ainda que lenta) da movimentação da agenda. 0 processo de credenciamento, de avaliação e certificação dos programas está sendo elaborado e negociado com o conjunto de atores da comissão.

Em 2013 o Ministério da Saúde lançou o Programa Mais Médicos, com o objetivo de ampliar draticamente o provimento de profissionais médicos para a atenção básica. São três os seus pilares: universalizar o acesso a Residência Médica; aumentar o número de vagas e de cursos de medicina em diversas regiões do país; e recrutar médicos em outros países. Esta terceira é o que ficou mais conhecido como Programa Mais Médicos para o Brasil, no entanto a legislação que o respalda prevê esse conjunto de ações.

Essa proposta ousada repercutiu negativamente na sociedade num primeiro momento por causa da forte pressão das entidades médicas, contrárias a proposta por razões de defesa de mercado.

Contudo, após o primeiro ano do programa, parcela significativa da sociedade já reconhece a potência do programa. 
A Lei no 12.871, de 22 de outubro de 2013, define como objetivos do programa:

I - diminuir a carência de médicos nas regiões prioritárias para o SUS, a fim de reduzir as desigualdades regionais na área da saúde;

II - fortalecer a prestação de serviços de atenção básica em saúde no País;

III - aprimorar a formação médica no País e proporcionar maior experiência no campo de prática médica durante o processo de formação;

IV - ampliar a inserção do médico em formação nas unidades de atendimento do SUS, desenvolvendo seu conhecimento sobre a realidade da saúde da população brasileira;

V - fortalecer a política de educação permanente com a integração ensino-serviço, por meio da atuação das instituições de educação superior na supervisão acadêmica das atividades desempenhadas pelos médicos;

VI - promover a troca de conhecimentos e experiências entre profissionais da saúde brasileiros e médicos formados em instituições estrangeiras;

VII - aperfeiçoar médicos para atuação nas políticas públicas de saúde do País e na organização e no funcionamento do SUS; e

VIII - estimular a realização de pesquisas aplicadas ao SUS.

E, ainda, propõem como suas ações:

I - reordenação da oferta de cursos de Medicina e de vagas para residência médica, priorizando regiões de saúde com menor relação de vagas e médicos por habitante e com estrutura de serviços de saúde em condições de ofertar campo de prática suficiente e de qualidade para os alunos;

II - estabelecimento de novos parâmetros para a formação médica no País; e

III - promoção, nas regiões prioritárias do SUS, de aperfeiçoamento de médicos na área de atenção básica em saúde, mediante integração ensino-serviço, inclusive por meio de intercâmbio internacional.

Existem muitas intencionalidades por trás dessa agenda, tanto no plano da formação como no plano da atenção. Buscou-se produzir dispositivos potentes para que a agenda do programa fosse capaz para produzir outros movimentos para além do simples provimento de profissionais médicos para trabalharem nas equipes de atenção básicas onde há falta desse profissional. O Programa Mais Médicos virou 
parte da agenda da Presidenta do Brasil, virou pauta da imprensa brasileira, houve um movimento intenso de resistência e enfrentamento por parte das entidades médicas.

Além de mais profissionais para a atenção básica, outros movimentos são pretendidos: consolidação da atenção básica como estratégia de produção do cuidado de forma universal, fortalecimento de uma nova prática na atenção básica a partir da influência, principalmente, dos médicos de família de Cuba, que tem presença relevante no programa; influência positiva para mudança no processo de produção do cuidado a partir de novas práticas menos voltadas para o modelo biomédico, focado na doença e no consumo de tecnologias assistenciais; ampliação no número de vagas de medicina influenciando no mercado da medicina no país; mudança no modelo de formação médica buscando ampliar a formação generalista e com conceito ampliado de saúde; etc.

Atualmente, já há aceitação do programa e muitos médicos brasileiros se interessaram em participar das novas edições em integração com o PROVAB. Novos desafios estão postos: efetivamente transformar a formação médica; superar os limites e riscos impostos pela ampliação de vagas com base majoritariamente em cursos privados; universalização da residência médica com capacidade de produzir outros sentidos para a formação médica, em intensa disputa com a corporação e o setor privado de atenção à saúde.

Não estão claros novos passos em relação à educação permanente - para além da brecha que a EPS em movimento abriu. Aparentemente prevalecerá a ideia de mais e mais cursos a distância, ainda que adotando estratégias mais participativas e convidativas. Não parece haver aposta na efetivação da política de educação na saúde como uma estratégia para produzir mais vida e participação na construção do SUS.

O movimento conceitual produzido pela política ao longo do tempo bem como o conjunto de documentos oficiais estudados podem ser observados na Linha do Tempo da Política de Educação na Saúde do SUS abaixo anexada. 


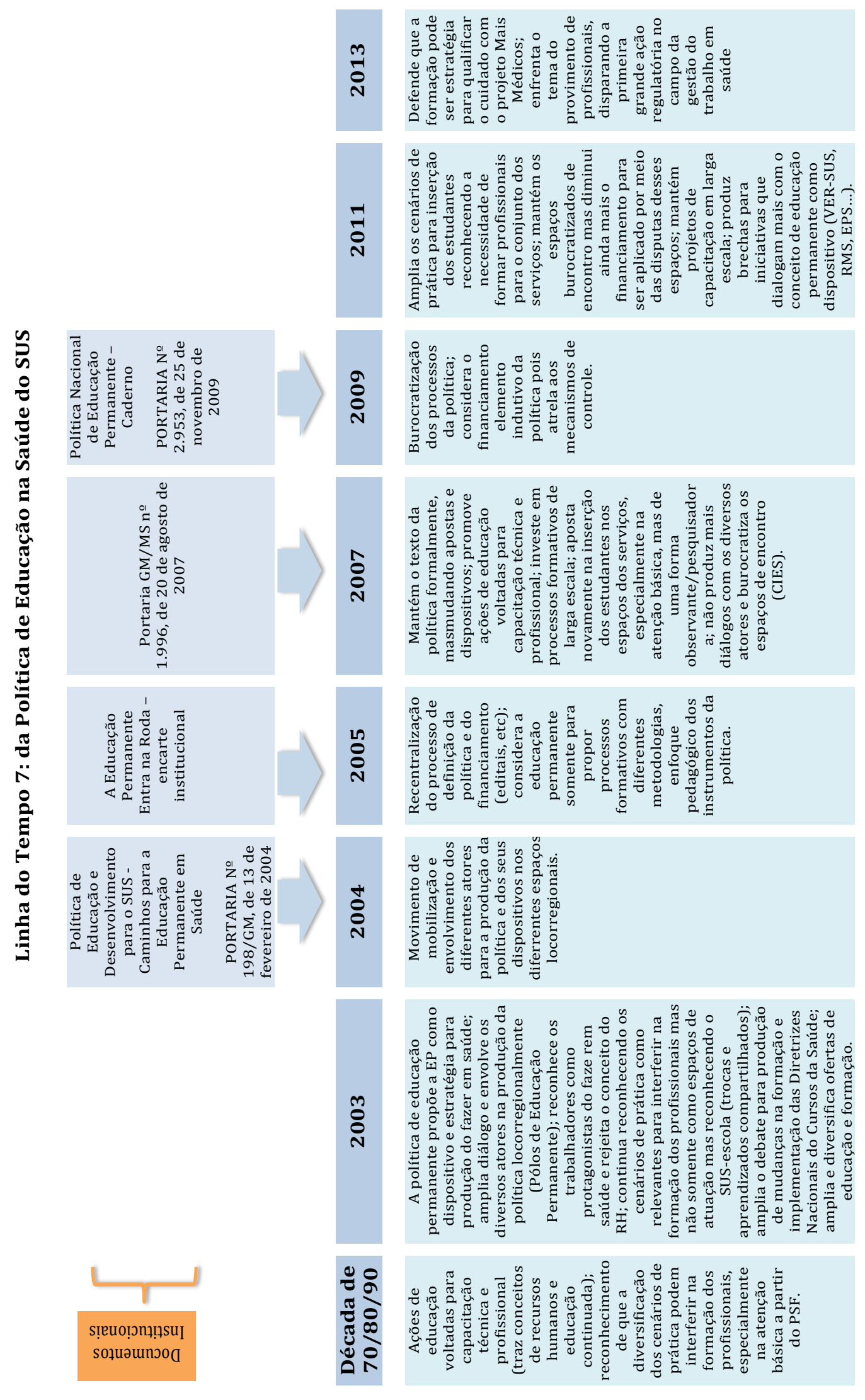


O olhar sobre as produções: encontros e desencontros no campo da

\section{Saúde Coletiva}

O olhar para as produções do campo da Saúde Coletiva foi realizado por meio da seleção, coleta, categorização e análise de teses, dissertações e artigos, Segundo estratégias já explicitadas.

Foram selecionadas 432 teses e dissertações de 6 Programas de Pós-Graduação do campo da Saúde Coletiva (ENSP, FSP/USP, IMS/UERJ, ISC/UFBA, MPREV/USP e UNICAMP). Também foram selecionados 684 artigos de três periódicos de relevância no campo da Saúde Coletiva: Cadernos de Saúde Pública, Ciência e Saúde Coletiva e Revista de Saúde Pública.

\section{Um olhar geral para o cenário dos Programas de Pós-Graduação}

Podemos identificar os diferentes programas e as produções de teses e dissertações sobre as 3 políticas neles selecionadas:

Gráfico 1: Distribuição das teses e dissertações selecionadas por programa de pós-graduação

\section{Programas de Pós-Graduação e produções (teses e dissertações) selecionadas}

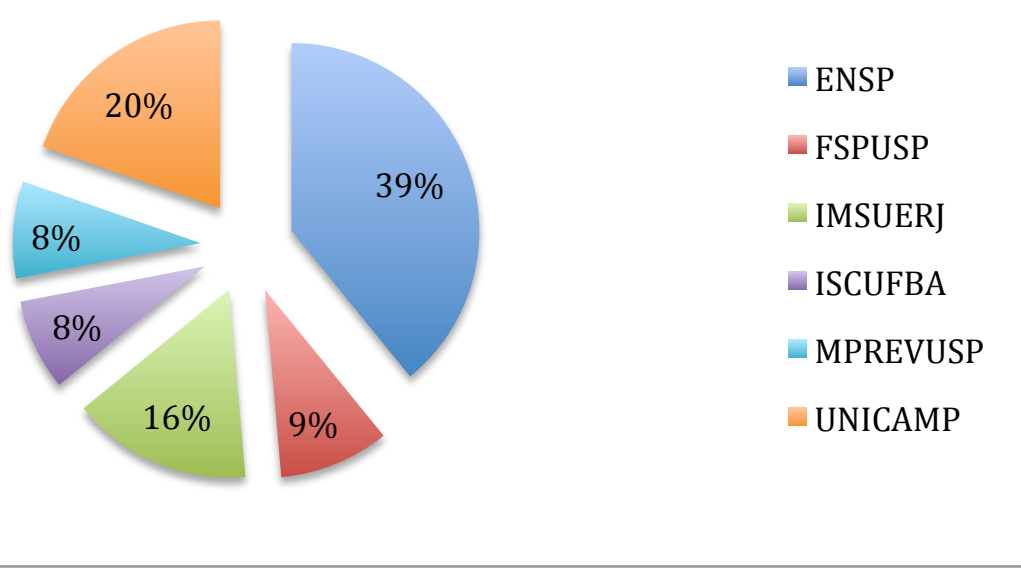

Esse gráfico apresenta a distribuição de dissertações e teses entre os programas a A ENSP apresenta o maior número de produções sobre as políticas estudadas, seguida da UNICAMP. 
A informatização do banco de teses é heterogênea entre as instituições, mesmo assim vale apresentar a distribuição da produção ao longo dos anos:

Tabela 11: Distribuição das teses e dissertações selcionadas por programa de pós-graduação ao longo dos anos (ano da defesa)

\begin{tabular}{|cccccccc|}
\hline Ano da Defesa & ENSP & FSPUSP & IMSUER & ISCUFBA & MPREVUSP & UNICAMP & Total \\
\hline $\mathbf{1 9 9 1}$ & & & & & & 1 & 1 \\
\hline $\mathbf{1 9 9 5}$ & & & & & & 3 & 3 \\
$\mathbf{1 9 9 7}$ & & & & & & 4 & 4 \\
\hline $\mathbf{1 9 9 8}$ & & & & & 1 & 2 & 3 \\
\hline $\mathbf{1 9 9 9}$ & & 1 & & & & 4 & 5 \\
\hline $\mathbf{2 0 0 0}$ & & & 3 & & 1 & 2 & 6 \\
\hline $\mathbf{2 0 0 1}$ & & 2 & 2 & & & 9 & 13 \\
\hline $\mathbf{2 0 0 2}$ & & 1 & & & & 3 & 4 \\
$\mathbf{2 0 0 3}$ & & & & & & 3 & 3 \\
\hline $\mathbf{2 0 0 4}$ & & 1 & & 1 & 1 & 9 & 12 \\
\hline $\mathbf{2 0 0 5}$ & 3 & 2 & & 1 & & 9 & 15 \\
\hline $\mathbf{2 0 0 6}$ & 5 & 2 & 7 & & 2 & 7 & 23 \\
\hline $\mathbf{2 0 0 7}$ & 5 & 5 & 7 & 2 & 5 & 3 & 27 \\
\hline $\mathbf{2 0 0 8}$ & 10 & 3 & 7 & 1 & 5 & 6 & 32 \\
\hline $\mathbf{2 0 0 9}$ & 34 & 5 & 13 & 5 & 7 & 4 & 68 \\
\hline $\mathbf{2 0 1 0}$ & 25 & 7 & 7 & 8 & 5 & 2 & 54 \\
\hline $\mathbf{2 0 1 1}$ & 26 & 4 & 6 & 5 & 4 & 6 & 51 \\
\hline $\mathbf{2 0 1 2}$ & 25 & 6 & 8 & 4 & 3 & 4 & 50 \\
\hline $\mathbf{2 0 1 3}$ & 29 & 2 & 5 & 7 & 1 & 4 & 48 \\
\hline $\mathbf{2 0 1 4}$ & 7 & & 2 & & 1 & & 10 \\
\hline Total & $\mathbf{1 6 9}$ & $\mathbf{4 1}$ & $\mathbf{6 7}$ & $\mathbf{3 4}$ & $\mathbf{3 6}$ & $\mathbf{8 5}$ & $\mathbf{4 3 2}$ \\
\hline
\end{tabular}

A concentração das produções posterior 2004 provavelmente tem a ver com a dinâmica de produção de políticas, uma certa ampliação da interação entre o SUS e o campo da saúde coletiva em função de várias políticas.

Isso, de certa forma, já é um indicador de um fluxo relacional entre os planos de produção das políticas e o da produção acadêmica. .

A próxima tabela mostra o tipo de produção (mestrado, mestrado professional, doutorado ou livre-docência), em cada programa

Tabela 12: Distribuição das teses e dissertações selecionadas por programa de pós-graduação

\section{Instituição e tipo de produção Total}

$\begin{array}{lcc} & \text { ENSP } & \\ \text { Dissertação } & 133 \\ \text { Tese } & 36 \\ \text { ENSP Total } & \mathbf{1 6 9}\end{array}$




\begin{tabular}{|c|c|}
\hline \multicolumn{2}{|c|}{ FSPUSP } \\
\hline Dissertação & 26 \\
\hline Tese & 13 \\
\hline Tese LD & 2 \\
\hline FSPUSP Total & 41 \\
\hline \multicolumn{2}{|c|}{ IMSUERJ } \\
\hline Dissertação & 39 \\
\hline Dissertação - Profissional & 2 \\
\hline Tese & 26 \\
\hline IMSUERJ Total & 67 \\
\hline \multicolumn{2}{|c|}{ ISCUFBA } \\
\hline Dissertação & 13 \\
\hline Dissertação - Profissional & 17 \\
\hline Tese & 4 \\
\hline ISCUFBA Total & 34 \\
\hline \multicolumn{2}{|c|}{ MPREVUSP } \\
\hline Dissertação & 23 \\
\hline Tese & 13 \\
\hline MPREVUSP Total & 36 \\
\hline \multicolumn{2}{|c|}{ UNICAMP } \\
\hline Dissertação & 46 \\
\hline Tese & 39 \\
\hline UNICAMP Total & 85 \\
\hline Total & 432 \\
\hline
\end{tabular}

A maior concentração de dissertações pode ser explicada pela duração mais breve do mestrado, o que proporciona maior rotatividade e produção.

Analisamos se as teses e as dissertações se basearam em pesquisas de campo/e/ou experiências ou se foram produções teóricas e/ou conceituais. 
Tabela 13: Distribuição das teses e dissertações selecionadas por programa de pós-graduação, classificadas na categoria experiências/práticas e teórico/conceitual

Programas experiências/campo teórico/conceitual Total

\begin{tabular}{|lccc|}
\hline ENSP & 145 & 24 & 169 \\
\hline FSPUSP & 41 & & 41 \\
\hline IMSUERJ & 58 & 9 & 67 \\
\hline ISCUFBA & 25 & 9 & 34 \\
MPREVUSP & 31 & 5 & 36 \\
UNICAMP & 74 & 11 & 85 \\
Total & $\mathbf{3 7 4}$ & $\mathbf{5 8}$ & $\mathbf{4 3 2}$ \\
\hline
\end{tabular}

Há uma expressiva concentração das produções em pesquisas de campo/ experiências e/ou práticas.

A maior parte dos estudos analisa a implementação de políticas, muitas das vezes em uma unidade, uma região da cidade. E toma o texto da política como referência para analisar a experiência, obtendo como resultado, na maioria das vezes, a identificação de insuficiências de implementação. Isso tem a ver com a compreensão acerca da produção de políticas adotada na maior parte dos estudos: o clássico ciclo das políticas, que define etapas estanques (formulação, implementação e avaliação), em que as disputas concentram-se no processo de formulação e a avaliação toma os elementos da política formulada como fonte para construer padrões/critérios avaliativos.

A próxima tabela mostra a distribuição dos lócus de estudo 
Tabela 14: Distribuição das teses e dissertações selecionadas por programa de pós-graduação, classificadas na categoria que indica a região de abrangência das pesquisas

\begin{tabular}{lccccccc} 
Programas & $\begin{array}{c}\text { município } \\
\text { Grande }\end{array}$ & $\begin{array}{c}\text { município } \\
\text { Médio }\end{array}$ & $\begin{array}{c}\text { município } \\
\text { Pequeno }\end{array}$ & ND & país & região & serviço/local \\
\hline ENSP & 37 & 12 & 6 & 51 & 12 & 36 & 15 \\
FSPUSP & 4 & 4 & 1 & 6 & & 10 & 16 \\
IMSUERJ & 7 & 15 & 2 & 13 & 13 & 12 & 5 \\
ISCUFBA & 3 & 1 & 1 & 3 & 8 & 13 & 5 \\
MPREVUSP & 5 & 2 & 1 & 3 & 4 & 5 & 16 \\
UNICAMP & 25 & 14 & 1 & 4 & 13 & 4 & 24 \\
Total & $\mathbf{8 1}$ & $\mathbf{4 8}$ & $\mathbf{1 2}$ & $\mathbf{7 6}$ & $\mathbf{5 0}$ & $\mathbf{8 0}$ & $\mathbf{8 1}$
\end{tabular}

É importante explicar pelo menos 3 das categorias utilizadas na tabela anterior e como foram empregadas:

- ND: foi utilizada quando não havia um recorte territorial possível de ser identificado;

- País: foi utilizada para todas as análises que foram de abrangência nacional, em geral, relacionadas a análises sobre a política ou algum elemento da política em geral;

- Região: foi utilizada para três tipos de arranjos regionais. Uma região dentro de um grande município que é maior do que um serviço/local; um arranjo intermunicipal que agrega mais de um município do mesmo estado ou interestadual, uma região; ou, ainda, um estado ou um arranjo de mais de um estado que pode ou não representar uma região política do país.

A maior parte dos estudos foi desenvolvida em serviços, ou nas grandes cidades, ou nas regiões territoriais. As inserções dos próprios programas e dos atores que os compõem interferem nesses locus de análise, pois com alguma frequência, os estudos ficaram mais centrados nos locus próximos ou no mesmo local em que os programas estão inseridos. Como as dissertações e teses em geral são produto de pesquisas conduzidas diretamente por seus autores é esperado que sejam feitos recortes geográficos ou de processos que tornem viáveis os estudos. Geralmente isso só não acontece quando as dissertações ou teses são "filhas" de uma pesquisa maior, levada a cabo por uma equipe. 


\section{Um olhar geral para os Periódicos}

O processo de análise construído foi semelhante ao desenvolvido com as teses e dissertações, mas nesse há atenção especial para a produção de filtros na definição do que é ou não publicado.

Já explicitamos que os periódicos foram escolhidos por sua relevância e pelo alto fator de impacto no campo da Saúde Coletiva - hoje definidos por um processo de avaliação da produção científica e acadêmica existente.

Sabemos que nem tudo que é produzido consegue ser publicado, e nem todos os periódicos utilizam dos mesmos critérios para seleção do que será publicado, considerando linhas editoriais etc. Isso tem importância, considerando que as revistas são um importante meio de divulgação da produção acadêmica. Quase o único, além dos livros. A distribuição dos artigos selecionados por periídocs é a seguinte:

Gráfico 2: Distribuição dos artigos por periódico

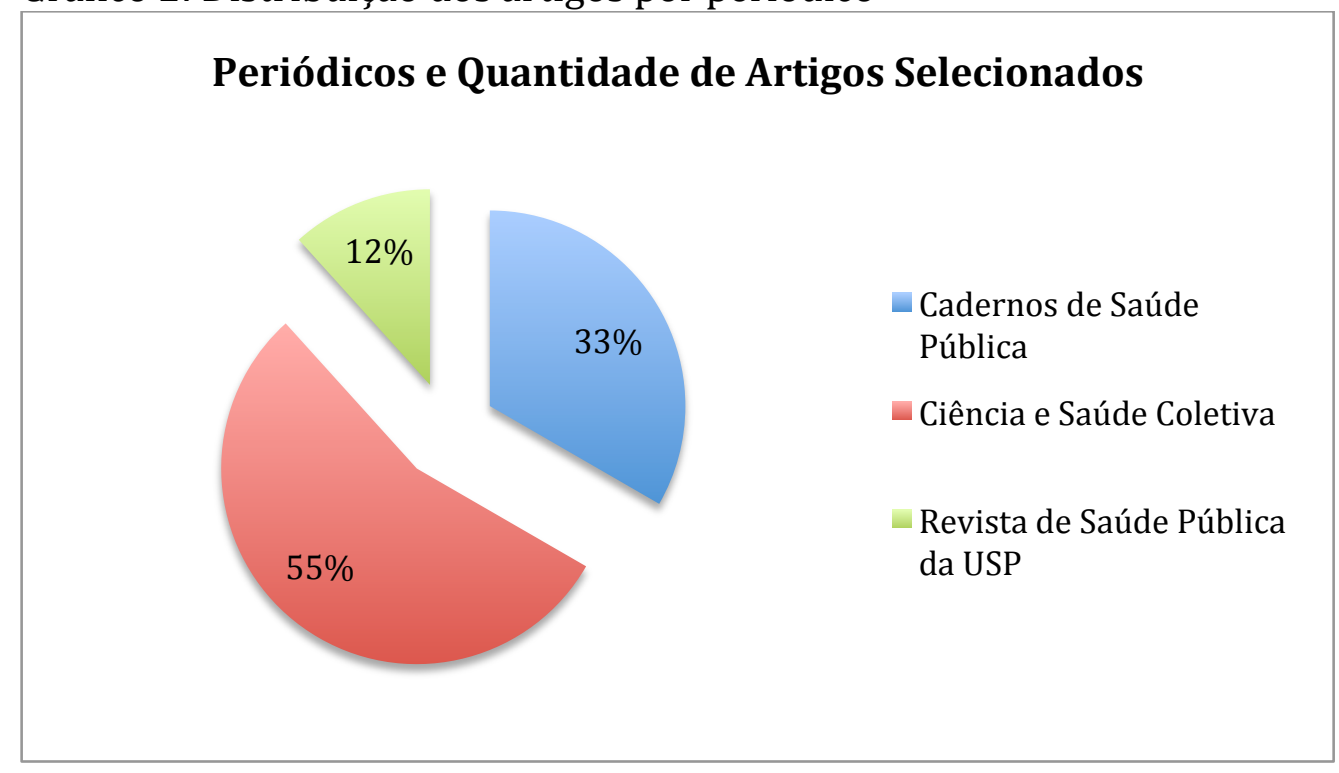

Apesar da Revista Ciência e Saúde Coletiva apresentar sua biblioteca on line somente a partir do ano de 1998, podemos perceber que ela concentra mais da metade dos artigos selecionados. De modo geral, essa revista foi a mais permeável à publicação de artigos no campo das políticas - todas elas. 
Tabela 15: Distribuição dos artigos selcionados por periódico ao longo dos anos (ano da publicação)

\begin{tabular}{|c|c|c|c|c|}
\hline ANO & $\begin{array}{l}\text { Cadernos de } \\
\text { Saúde Pública }\end{array}$ & $\begin{array}{c}\text { Ciência e Saúde } \\
\text { Coletiva }\end{array}$ & $\begin{array}{l}\text { Revista de Saúde } \\
\text { Pública da USP }\end{array}$ & Total \\
\hline 1989 & 4 & & 1 & 5 \\
\hline 1990 & 1 & & 1 & 2 \\
\hline 1991 & & & 2 & 2 \\
\hline 1992 & 6 & & 1 & 7 \\
\hline 1993 & 3 & & & 3 \\
\hline 1995 & & & 2 & 2 \\
\hline 1996 & 1 & & & 1 \\
\hline 1997 & 1 & & 2 & 3 \\
\hline 1998 & 3 & 1 & & 4 \\
\hline 1999 & 4 & 4 & 3 & 11 \\
\hline 2000 & 5 & 1 & 1 & 7 \\
\hline 2001 & 3 & 9 & 2 & 14 \\
\hline 2002 & 8 & 10 & 2 & 20 \\
\hline 2003 & 4 & 8 & 2 & 14 \\
\hline 2004 & 11 & 6 & & 17 \\
\hline 2005 & 8 & 12 & 5 & 25 \\
\hline 2006 & 8 & 19 & 2 & 29 \\
\hline 2007 & 18 & 17 & 1 & 36 \\
\hline 2008 & 40 & 22 & 7 & 69 \\
\hline 2009 & 19 & 43 & 9 & 71 \\
\hline 2010 & 24 & 43 & 6 & 73 \\
\hline 2011 & 14 & 68 & 6 & 88 \\
\hline 2012 & 20 & 43 & 10 & 73 \\
\hline 2013 & 11 & 29 & 8 & 48 \\
\hline 2014 & 12 & 41 & 7 & 60 \\
\hline Total & 228 & 376 & 80 & 684 \\
\hline
\end{tabular}

A distribuição dos artigos ao longo do tempo mostra uma intensificação da publicação relativa ao tema das políticas a partir dos anos 2000.

Do mesmo modo que em relação às teses e dissertações, a publicação dos artigos parece confirmar, como mencionado, uma intensificação do diálogo entre o SUS e a academia. Vale destacar que a partir de 2003/2004, o Ministério da Saúde passou ele próprio a lançar editais de pesquisa em parceria com o CNPq, explicitando suas questões de interesse. 0 primeiro edital específico para a área de políticas, no entanto, foi lançado apenas há dois anos.

A próxima tabela mostra a distribuição dos artigos quanto ao tipo. Esse é um dos possíveis filtros que podemos identificar nos periódicos já que os artigos que 
apresentam resultados de pesquisas correspondem a 77,2\% do total de artigos aqui selecionados (há uma preferência à publicação de artigos produto de pesquisas).

Tabela 16: Distribuição dos artigos selecionados por periódico, classificados na categoria de trabalho científico

\begin{tabular}{lccccc} 
Periódicos & Teórico & $\begin{array}{c}\text { Rel. de } \\
\text { Experiência }\end{array}$ & Opinião & Pesquisa & $\begin{array}{c}\text { Revisão } \\
\text { Bibliográfica }\end{array}$ \\
\hline $\begin{array}{l}\text { Cadernos } \\
\text { de Saúde } \\
\text { Pública }\end{array}$ & 22 & 9 & 8 & 186 & 3 \\
$\begin{array}{l}\text { Ciência e } \\
\text { Saúde } \\
\text { Coletiva }\end{array}$ & 47 & 17 & 15 & 274 & 23 \\
$\begin{array}{l}\text { Revista de } \\
\text { Saúde } \\
\text { Pública da }\end{array}$ & 2 & 6 & 1 & 68 & 3 \\
$\begin{array}{l}\text { USP } \\
\text { Total }\end{array}$ & & & & & \\
\hline
\end{tabular}

Não se pretende insinuar que as produções teóricas não sejam produtos de pesquisa. Só fizemos esse destaque porque nos interessava explicitar as pesquisas que usaram as práticas ou os serviços de saúde como campo.

Sobre que territórios estão sendo produzidas análises sobre políticas? 
Tabela 17: Distribuição dos artigos selecionados por periódico, classificados na categoria que indica a região de abrangência das pesquisas

\begin{tabular}{|c|c|c|c|c|c|c|c|}
\hline REVISTA & $\begin{array}{c}\text { município } \\
\text { G }\end{array}$ & $\underset{M}{\text { município }}$ & $\begin{array}{c}\text { município } \\
\text { P }\end{array}$ & ND & país & região & $\begin{array}{c}\text { serviço/ } \\
\text { local }\end{array}$ \\
\hline $\begin{array}{l}\text { Cadernos de } \\
\text { Saúde } \\
\text { Pública }\end{array}$ & 50 & 33 & 7 & 45 & 13 & 78 & 2 \\
\hline $\begin{array}{l}\text { Ciência e } \\
\text { Saúde } \\
\text { Coletiva }\end{array}$ & 74 & 42 & 9 & 153 & 12 & 48 & 38 \\
\hline $\begin{array}{l}\text { Revista de } \\
\text { Saúde } \\
\text { Pública da } \\
\text { USP }\end{array}$ & 29 & 11 & 4 & 4 & 9 & 22 & 1 \\
\hline Total & 153 & 86 & 20 & 202 & 34 & 148 & 41 \\
\hline
\end{tabular}

A grande ocorrência na categoria ND pode ser explicada por diferentes questões: concentram-se nessa categoria os estudos teóricos, de revisão bibliográfica e de opinião; também existem alguns estudos que não definem para análise um recorte territorial . Essa categoria também foi utilizada quando não foi possível identificar algum recorte territorial específico, seja pelo resumo pouco claro, seja pela não definição metodológica desse recorte.

Procuramos também identificar se os artigos publicados correspondiam às teses e dissertações produzidas nesses programas de Saúde Coletiva. Esperava-se que muitas dessas dissertações e teses fossem encontradas nas revistas pesquisadas já que são as com maior fator de impacto do campo. No entanto, não foi isso que encontramos.

Para realizar essa etapa da pesquisa, foram cruzados os nomes dos autores dos artigos com os nomes dos autores de teses e dissertações e dos seus respectivos orientadores. Tal comparação permitiu identificar 45 artigos publicados com algum autor igual. Contudo, ao refinar essa busca comparando as temáticas abordadas nos artigos com as teses e dissertações, restaram somente 12 artigos. Dentre esses 12 artigos, somente 1 foi publicado na Revista de Saúde Pública da USP, 4 foram publicados nos Cadernos de Saúde Pública e os outros 7 foram publicados na Ciência e Saúde Coletiva.

Abaixo, vemos ao artigos que foram identificados como produtos dos mestrados e doutorados pesquisados, publicados nas revistas selecionadas. 
Tabela 18: Artigos publicados em periódicos resultantes de pesquisas nos programas de pós-graduação pesquisados segundo ano de publicação

\begin{tabular}{|c|c|c|}
\hline Revista & Título do Artigo & Ano \\
\hline $\begin{array}{l}\text { Cadernos de Saúde } \\
\text { Pública }\end{array}$ & $\begin{array}{l}\text { Estratégia Saúde da Família e a atenção ao idoso: } \\
\text { experiências em três municípios brasileiros }\end{array}$ & 2011 \\
\hline $\begin{array}{l}\text { Cadernos de Saúde } \\
\text { Pública }\end{array}$ & $\begin{array}{l}0 \text { agente comunitário de saúde: formação, inserção } \\
\text { e práticas }\end{array}$ & 2008 \\
\hline Ciência e Saúde Coletiva & $\begin{array}{l}\text { Conexões entre o federalismo fiscal e o } \\
\text { financiamento da política de saúde no Brasil }\end{array}$ & 2007 \\
\hline $\begin{array}{l}\text { Revista de Saúde Pública } \\
\text { da USP }\end{array}$ & $\begin{array}{l}\text { Regionalização e dinâmica política do federalismo } \\
\text { sanitário brasileiro }\end{array}$ & 2011 \\
\hline Ciência e Saúde Coletiva & $\begin{array}{l}\text { O Programa de Agentes Comunitários de Saúde no } \\
\text { Ceará: o caso de Uruburetama }\end{array}$ & 2011 \\
\hline Ciência e Saúde Coletiva & $\begin{array}{l}\text { Saúde mental na atenção primária à saúde: estudo } \\
\text { avaliativo em uma grande cidade brasileira }\end{array}$ & 2011 \\
\hline Ciência e Saúde Coletiva & $\begin{array}{l}\text { Saúde Mental na atenção básica à saúde de } \\
\text { Campinas, SP: uma rede ou um emaranhado? }\end{array}$ & 2009 \\
\hline $\begin{array}{l}\text { Cadernos de Saúde } \\
\text { Pública }\end{array}$ & $\begin{array}{l}\text { Necessidades de saúde e masculinidades: atenção } \\
\text { primária no cuidado aos homens }\end{array}$ & 2010 \\
\hline Ciência e Saúde Coletiva & $\begin{array}{l}\text { Concepções de gênero, masculinidade e cuidados } \\
\text { em saúde: estudo com profissionais de saúde da } \\
\text { atenção primária }\end{array}$ & 2011 \\
\hline Ciência e Saúde Coletiva & $\begin{array}{l}\text { Humanidades e medicina: razão e sensibilidade na } \\
\text { formação médica }\end{array}$ & 2010 \\
\hline $\begin{array}{l}\text { Cadernos de Saúde } \\
\text { Pública }\end{array}$ & $\begin{array}{l}\text { O desafio da descentralização do Sistema Único de } \\
\text { Saúde em município de grande porte: o caso de São } \\
\text { Paulo, Brasil }\end{array}$ & 2009 \\
\hline Ciência e Saúde Coletiva & $\begin{array}{l}\text { Regionalização e acesso à saúde nos estados } \\
\text { brasileiros: condicionantes históricos e político- } \\
\text { institucionais }\end{array}$ & 2012 \\
\hline
\end{tabular}

Um outro estudo feito nesse banco de dados foi em relação ao tempo entre a realização da pesquisa e a publicação dos artigos. Nem todos os artigos apresentaram esses dados, mas os que apresentaram foram destacadas.

Na Revista Cadernos de Saúde Pública, 123 artigos, dentre os 228 aqui analisados, tiveram os dados de temporalidade destacados. Fazendo um exercício linear, destaca-se que o intervalo médio entre o ano de pesquisa e o ano de publicação do artigo foi de 3,3 anos. Essa média não apresenta padrão, já que existem tanto artigos que foram publicados no mesmo ano da pesquisa, como artigos que foram publicados 10 anos depois da pesquisa.

Na Revista Ciência e Saúde Coletiva, foram identificados 121 artigos, dentre os 376 selecionados, com informações relativas aos anos de pesquisa e publicação. 
0 intervalo médio entre a pesquisa e publicação é de 3,32 anos, sendo que existem artigos publicados no mesmo ano da pesquisa e outros com até 10 anos de intervalo. Da mesma forma que na Cadernos de Saúde Pública, a maior concentração apresenta um intervalo entre 2 e 5 anos.

Na Revista de Saúde Pública da USP, foram identificados 64 artigos, dentre os 80 selecionados. Dos 80 artigos, 68 foram identificados por serem provenientes de pesquisa e, destes, 64 apresentaram informação sobre o ano de realização da pesquisa e da publicação. A media também é parecida com as outras duas revistas, aqui é de 3,32 anos, sendo que o menor tempo foi de 1 ano e o maior, de 9 anos. A maior concentração de artigos apresenta entre 2 a 4 anos de intervalo entre a pesquisa e a publicação.

Tabela 19: Distribuição dos artigos por periódico e por tempo de intervalo entre produção e publicação

\begin{tabular}{|ccccc|}
\hline TEMPO & $\begin{array}{c}\text { Revista de Saúde } \\
\text { Pública }\end{array}$ & $\begin{array}{c}\text { Ciiencia e Saúde } \\
\text { Coletiva }\end{array}$ & $\begin{array}{c}\text { Cadernos de Saúde } \\
\text { Pública }\end{array}$ & Total \\
\hline $\mathbf{0}$ & & 3 & 1 & 4 \\
$\mathbf{1}$ & 4 & 9 & 8 & 21 \\
\hline $\mathbf{2}$ & 17 & 24 & 28 & 69 \\
$\mathbf{3}$ & 11 & 36 & 40 & 87 \\
$\mathbf{4}$ & 19 & 26 & 27 & 72 \\
$\mathbf{5}$ & 6 & 16 & 13 & 35 \\
$\mathbf{6}$ & 3 & 3 & 2 & 8 \\
\hline $\mathbf{7}$ & 3 & 1 & 1 & 5 \\
$\mathbf{8}$ & & 2 & 2 & 4 \\
\hline $\mathbf{9}$ & 1 & 1 & & 1 \\
\hline $\mathbf{1 0}$ & & $\mathbf{1 2 1}$ & $\mathbf{1 2 3}$ & $\mathbf{3 0 8}$ \\
\hline Total & $\mathbf{6 4}$ & & & \\
\hline
\end{tabular}


Um olhar para as políticas de saúde selecionadas e seus encontros com a cadeia produtiva do conhecimento do campo da Saúde Coletiva

A partir de agora vamos apresentar os dados específicos de cada política. Para melhor explorar o material, foram criadas categorias temáticas para caracterização dos temas abordados nos diferentes estudos analisados.

\section{Política de Atenção Básica}

É a política que concentra o maior número de estudos. Isso mostra consonância da academia com a priorização da atenção básica, tanto por ser fundamental para a efetivação do SUS para todos os brasileiros, como por haver grande concordância (os estudos indicam isso) com a aposta em sua potência transformadora em relação ao modelo de atenção.

No contexto geral da produção do campo, observando tanto a produção das teses e dissertações como os artigos, notamos distribuição regular de estudos entre as grandes categorias relativas a atenção básica, conforme é possível observar no gráfico abaixo.

Gráfico 3: Distribuição das teses, dissertações e artigos selecionados por categoria temática da Política de Atenção Básica, segundo ano de ocorrência

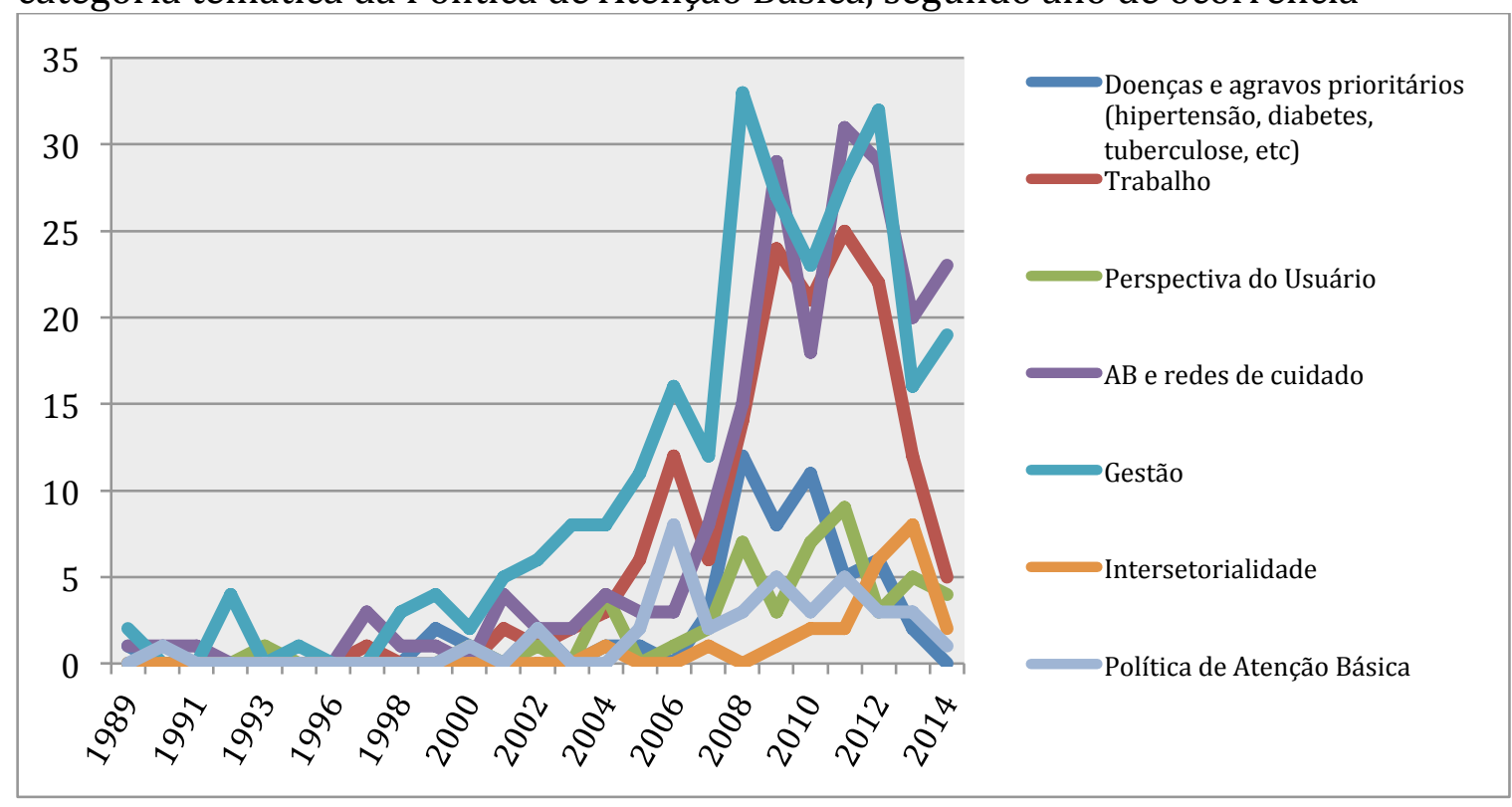

Foram estudados 253 teses e dissertações e 527 artigos em que a categoria prioritária temática estava relacionada a essa política. As categorias que 
abordam os temas da gestão, do trabalho e das redes de atenção básica são as que apresentam o maior número de produções ao longo dos anos.

Há um aumento significativo na ocorrência dos artigos a partir de 2006, o que sugere uma relação com o próprio processo de produção da política, pois foi a partir de 2003 que a saúde da família foi assumida como política e não mais como programa ou estratégia. E as categorias com maior ocorrência compõem parte significativa das formulações dos elementos da política.

Gráfico 4: Distribuição dos artigos selecionados por categoria temática da Política de Atenção Básica, segundo ano de publicação

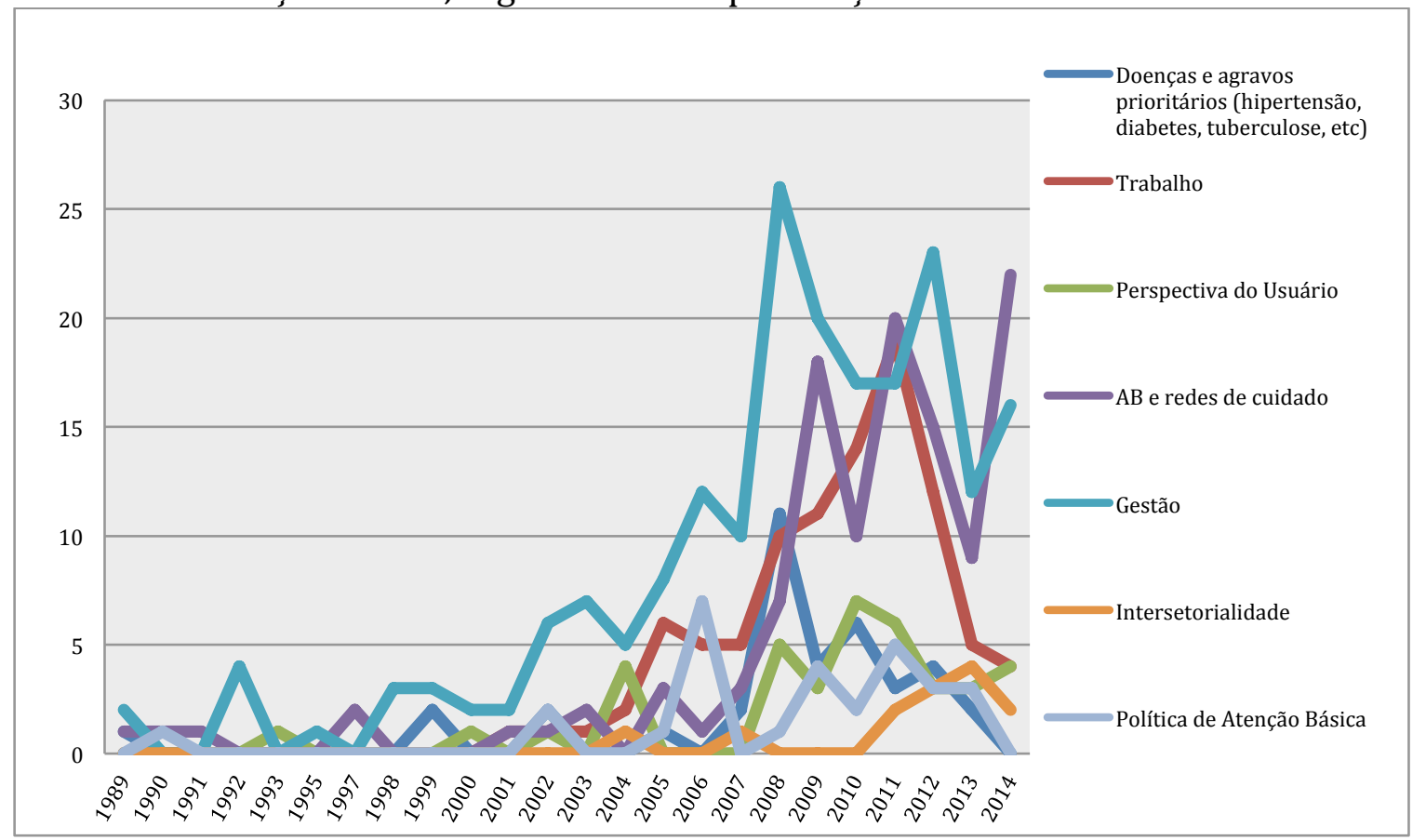

0 ano de 2007 foi muito importante para os artigos que abordam o tema da gestão (talvez algo a ver com os estudos de linha de base desenvolvidos a partir do Proesf). 0 ano de 2011, para os artigos que abordam o tema do trabalho e das redes de cuidado (redes e regiões tiveram debate intensificado a partir do Pacto, antes da proposição das redes temáticas). 
Gráfico 5: Distribuição das teses e dissertações selecionadas por categoria temática da Política de Atenção Básica, segundo ano de defesa

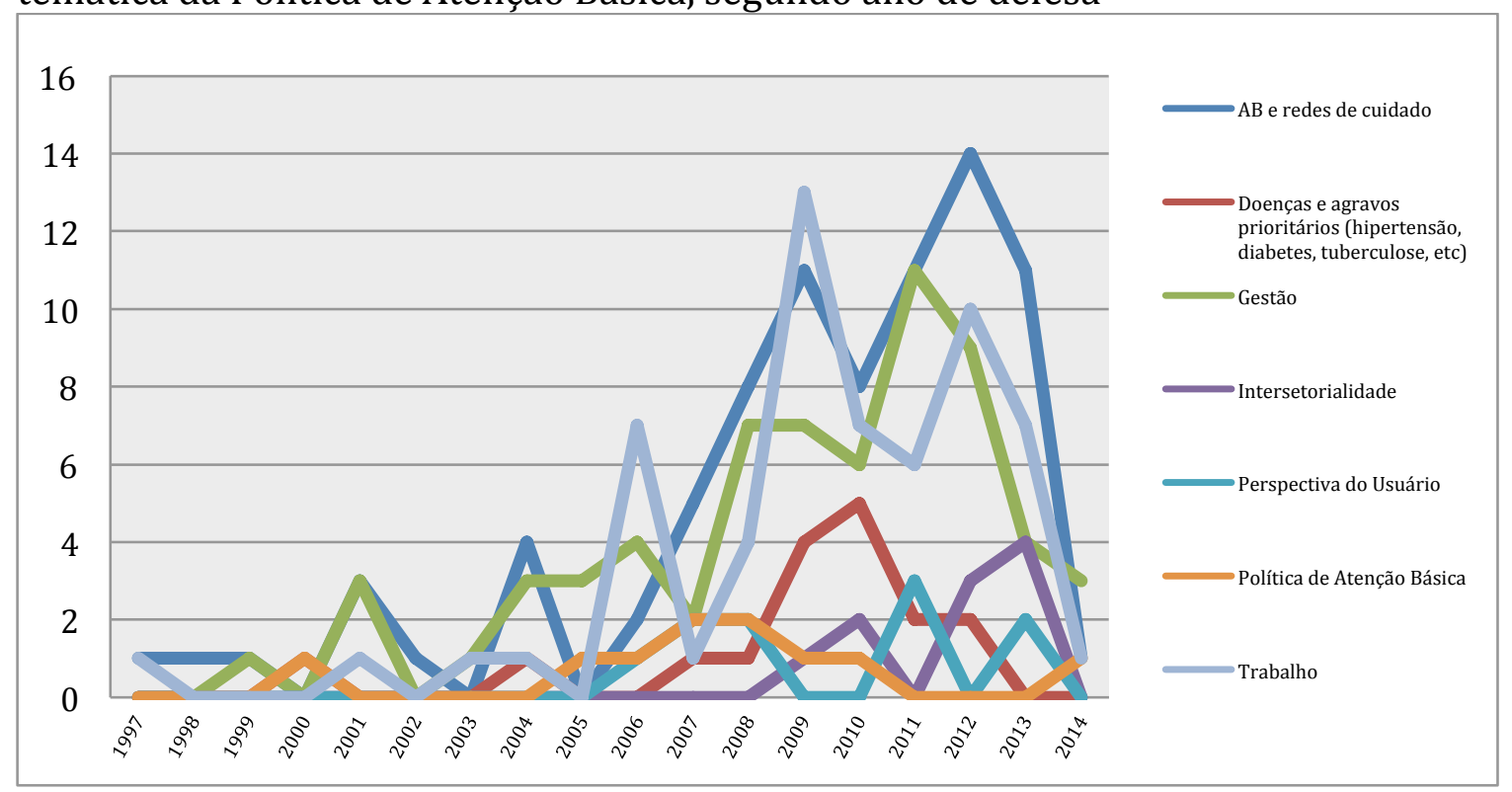

No caso das teses e dissertações, há um movimento mais convergente entre as 3 principais categorias temáticas, com dois picos mais significativos em 2008 e em 2012.

Se observadas essas categorias, veremos que:

1. Trabalho:

a. Artigos são publicados no período entre 2001 e 2014, estando em maior concentração no período entre 2008 e 2012, com as seguintes sub-categorias:

i. Atuação de categorias profissionais: período entre 2003 e 2014, com maior concentração entre 2008 e 2012

ii. Processo de Trabalho: período entre 2007 e 2012, sendo que em 2010 tem mais ocorrências

iii. Agentes Comunitários de Saúde (ACS): período entre 2005 e 2013, havendo maior concentração em 2011

b. Teses e Dissertações defendidas entre 2006 e 2014, com maior concentração em 2009, com as seguintes sub-categorias:

i. Atuação de categorias profissionais: período entre 2009 e 2012, sendo defendidas em maior número no ano de 2010

ii. Processo de Trabalho: período entre 2008 e 2012, maior concentração em 2011 
iii. Agentes Comunitários de Saúde (ACS): período entre 2006 e 2009, com maior concentração em 2006 e 2009

iv. O tema do trabalho é tratado principalmente sob o enfoque da Atuação de categorias profissionais (universitárias) e dos Agentes Comunitários de Saúde (ACS). O Processo de trabalho também é abordado nos estudos, mas não tão intensamente. ACS sempre foram foco de atenção por ser elemento de novidade no trabalho da atenção básica. 0 tema das categorias profissionais específicas ganhou força a partir da criação dos NASFs.

2. Atenção Básica e Redes de Cuidado:

a. Artigos publicados entre 2001 e 2014, com maior concentração entre 2008 a 2012, com as seguintes sub-categorias:

i. Diversificação das ofertas de cuidado: entre 2009 e 2014

ii. Produção do Cuidado: entre 2007 e 2013, 2011 com maior concentração

iii. Acesso a ações e serviços de saúde: entre 2008 e 2014, mais ocorrências em 2012

iv. Ações programáticas: entre 2008 e 2014, este último com maior concentração

b. Teses e Dissertações defendidas entre 2006 e 2014, maior número de defesas entre 2009 e 2013, com as seguintes sub-categorias:

i. Ações programáticas: entre 2006 e 2014

ii. Integralidade: entre 2008 e 2012

iii. Diversificação das ofertas de cuidado: entre 2007 e 2013, mais ocorrências em 2013

Ações programáticas e Diversificação das ofertas de cuidado são relacionados à lógica principal de organização do trabalho das equipes e provavelmente também às influências que a presença das equipes multiprofissionais dos NASFs produziram.

As outras questões estudadas tem a ver com o movimento de incorporação de outros conceitos/dispositivos na tentativa de qualificar a atenção produzida a partir da vigilância em saúde: clínica ampliada, dispositivos para produção do cuidado, acolhimento etc. 
3. Gestão:

a. Artigos publicados entre 98 e 2014, mais concentrados entre 2008 e 2012, nas sub-categorias:

i. Modelo de atenção: entre 2006 e 2009, maior número em 2006

ii. Avaliação: entre 2001 e 2014, mais concentrados entre 2008 e 2014

b. Teses e Dissertações defendidas entre 2003 e 2014, mais concentradas entre 2008 e 2012, com as seguintes sub-categorias:

i. Modelo de atenção: entre 2001 e 2013

ii. Avaliação: entre 2008 e 2012, concentração entre 2011 e 2012

4. Outras sub-categorias com número relevante de produções:

a. Artigos:

i. Vigilância em saúde: entre 2007 e 2013, sendo mais significativo 2008

ii. Ponto de vista/avaliação do usuário: 2008 e 2014, mais concentrados entre 2010 e 2011

iii. Política de atenção básica: 2005 e 2013, maior ocorrência em 2006, 2009 e 2011

b. Teses e Dissertações:

i. Política de atenção básica: entre 2005 e 2010

A maior concentração das produções que abordam a atenção básica ocorre entre 2008 e 2013. Do total das producões de artigos, teses e dissertações estudadas, nota-se aumento significativo nas produções a partir de 2006 e 2007, provavelmente pelas razões já indicadas. 
Gráfico 6: Distribuição das produções selecionadas da Política de Atenção Básica por tipo de produção segundo ano ocorrência

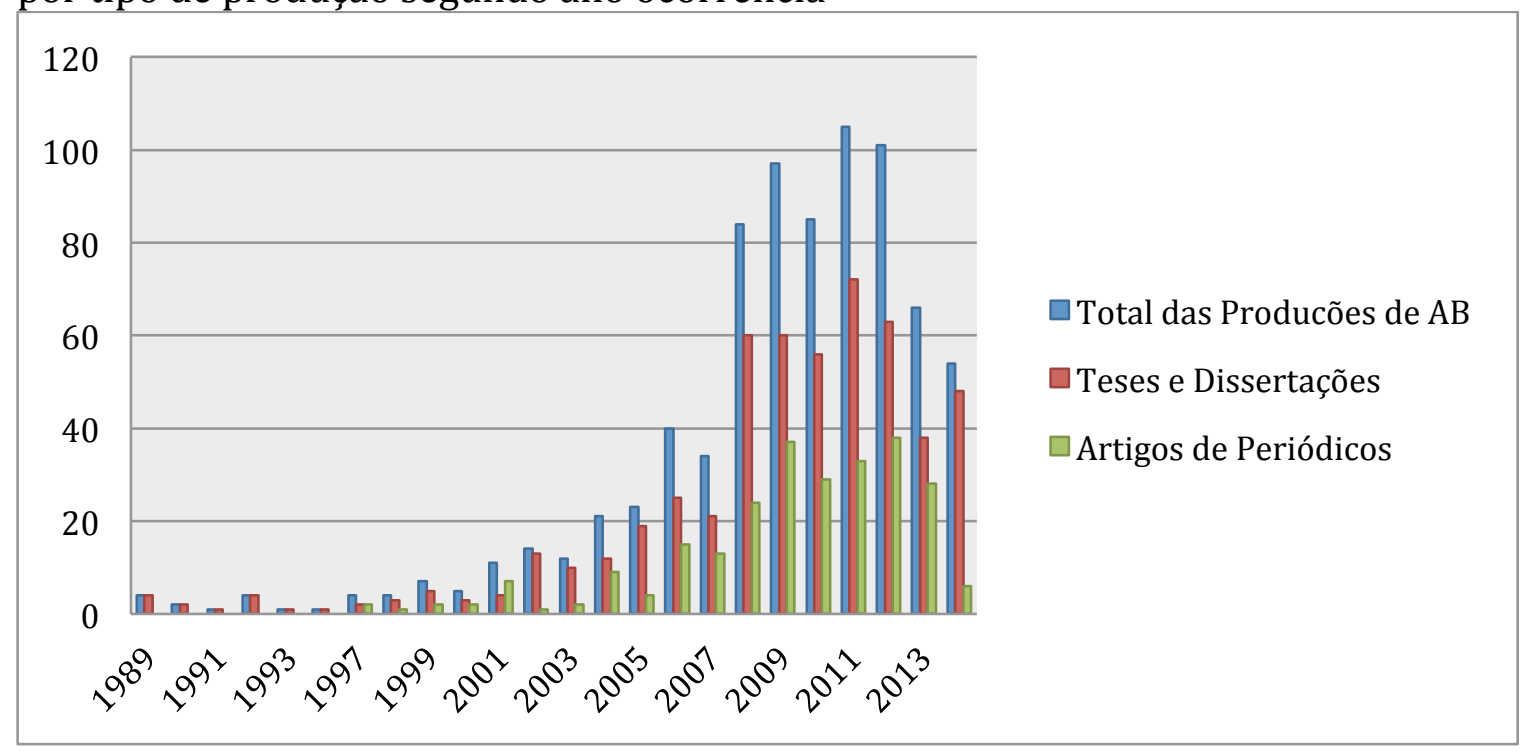

Se observadas as categorias temáticas, percebemos que entre os periódicos e os programas de pós-graduação há apostas de estudo diferentes, tantos entre os períodicos e programas, como entre cada um deles. Podemos destacar:

1. Revista de Saúde Pública da USP:

a. Principal categoria estudada: gestão, mais especificamente a subcategoria avaliação.

2. Revista Ciência e Saúde Coletiva:

a. Trabalho é uma das categorias mais estudadas, abordando os temas: atuação de categoria professional, processo de trabalho e ACS.

b. Perspectiva dos usuários também foi estudada

c. Atenção Básica e redes de cuidado foi estudada especialmente com as sub-categorias: diversificação de ofertas de cuidado, acesso a ações e serviços de saúde e ações programáticas.

d. Gestão foi estudada especialmente pela sub-categoria avaliação.

e. A política de atenção básica também foi estudada.

3. Cadernos de Saúde Pública:

a. A principal categoria estudada foi a gestão a partir de duas subcategorias: planejamento e avaliação.

Essa distribuição provavelmente está relacionada aos filtros e áreas de interesse estabelecidos pelas editorias das revistas.

A distribuição dos artigos pelos periódicos está no gráfico abaixo. 
Gráfico 7: Distribuição dos artigos selecionados da Política de Atenção Básica segundo periódico

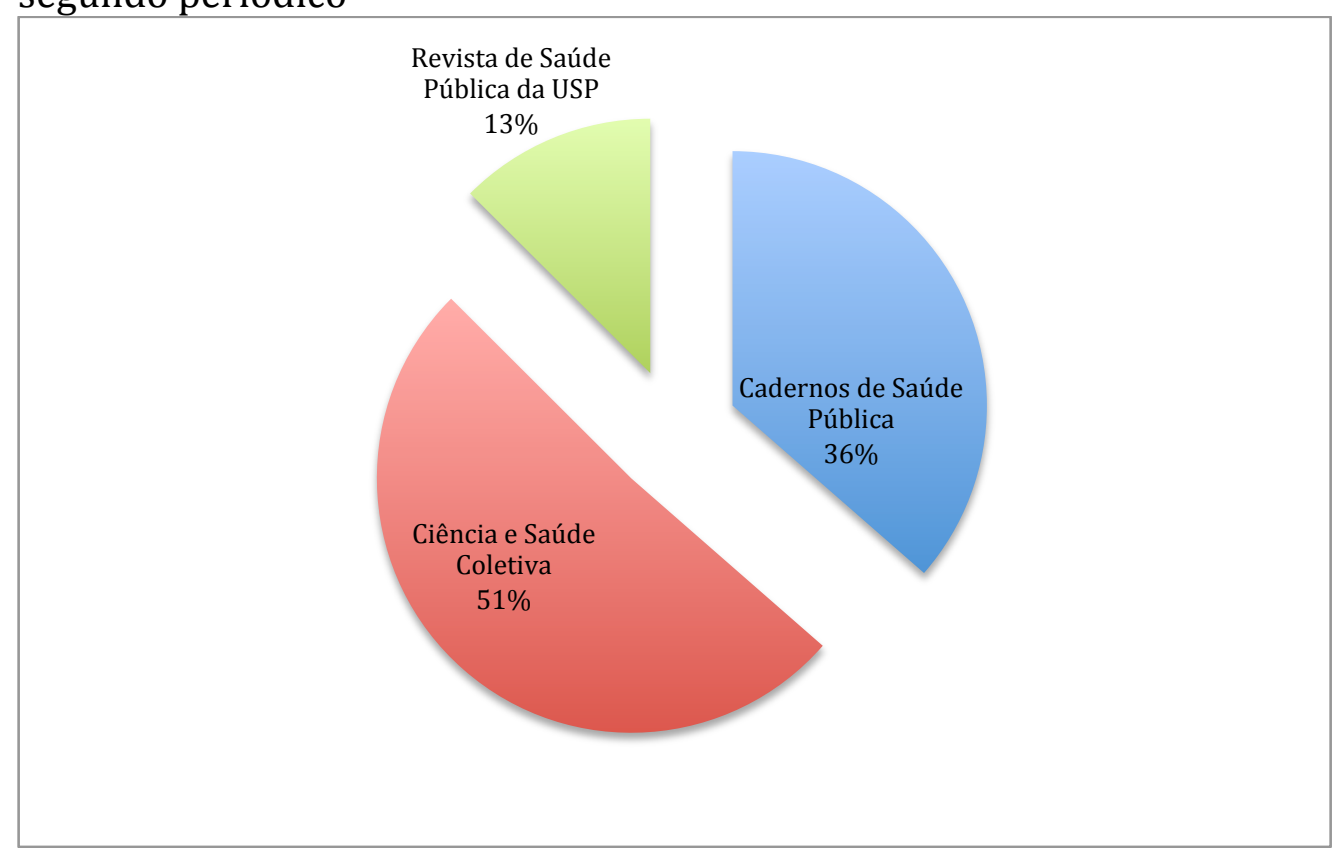

Entre teses e dissertações também há diferenças de enfoque entre os programas de pós-graduação, são elas:

1. UNICAMP:

a. A principal categoria estudada foi a gestão, especialmente a subcategoria dos modelos de atenção.

2. MPREV USP:

a. A categoria mais estudada foi atenção básica e as redes de cuidado, principalmente a partir do estudo da sub-categoria diversificação das ofertas de cuidado.

3. ISC UFBA:

a. Atenção básica e redes de cuidado foi estudada a partir do tema da sub-categoria integralidade.

b. A gestão também foi estudada por meio de duas sub-categorias: planejamento e avaliação.

4. IMS UERJ:

a. A categoria do trabalho foi estudada especialmente pela sub-categoria ACS.

b. A categoria da gestão também foi estudada e especialmente a partir da sub-categoria dos modelos de atenção.

5. FSP USP: 
a. A principal categoria estudada foi a atenção básica e as redes de cuidado a partir da sub-categoria diversificação das ofertas de cuidado.

\section{ENSP:}

a. A principal categoria estudada foi a gestão especialmente por meio da sub-categoria avaliação.

Grupos e linhas de pesquisa existentes nas instituições influenciam de modo importante a produção de dissertações e teses, o que pode explicar as diferenças encontradas. Áreas de interesse dos próprios pós-graduandos também interferem em suas escolhas: muitos deles são trabalhadores de saúde e, quando autorizados, estudam temáticas relacionadas a sua próprias experiências.

Gráfico 8: Distribuição das teses e dissertações selecionadas da Política de Atenção Básica segundo programa de pós-graduação

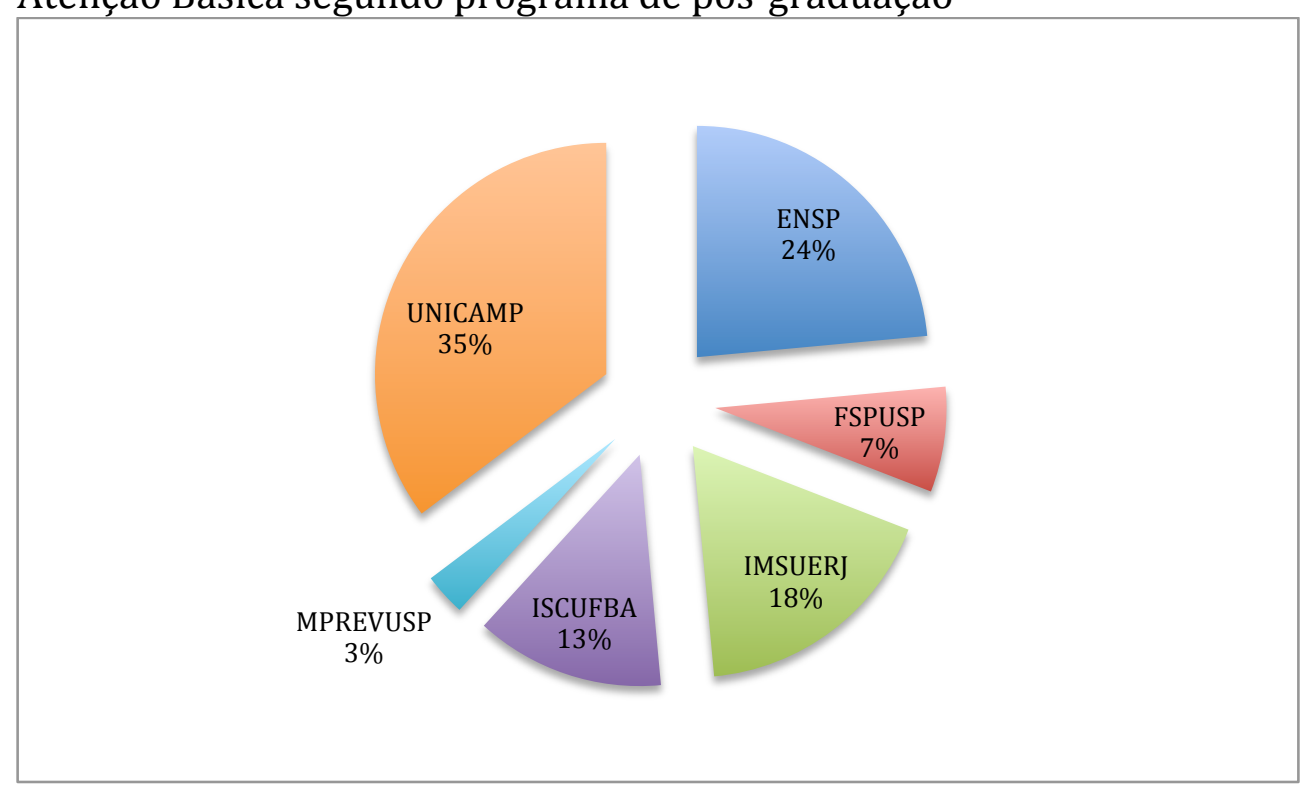

Ao observarmos esse movimento politico e conceitual que ocorreu no âmbito da Política de Atenção Básica iremos perceber alguns pontos de contato.

De forma geral, vemos que existe uma certa relação temática entre as produções da política e do campo da Saúde Coletiva. 0 tema da política de atenção básica é objeto das políticas e das produções do campo em momentos que se relacionam. Da mesma forma, o tema da gestão também é abordado em ambos os planos de produção. Contudo, o que se observa quando é feito um olhar mais atento ao que está sendo produzido, é que o enfoque do que está sendo produzido não é o mesmo, percebe-se que há uma certa convergência no temário geral mas as 
perguntas que estão presentes nas produções do campo da saúde coletiva, não são as perguntas que o sistema de saúde precisa responder para o desenvolvimento das suas políticas. Percebe-se que os temas, muitas vezes, são os mesmos no entanto o enfoque, as perguntas estudadas, nem sempre são convergentes.

O tema da política de atenção básica foi abordado pelas teses, dissertações e artigos através de estudos mais genéricos, em geral atrelados ao enfoque dos resultados de alguma de ação de saúde mais específica, ou através de estudos sobre os dispositivos específicos da política. Os estudos foram predominantemente descritivos e isso aponta um certo olhar para a avaliação da implementação da política, no caso, de ações específicas ou dos seus dispositivos. 0 tema da gestão da política da atenção básica teve um movimento interessante pois nota-se que ele esteve quase todo o tempo presente, tanto na produção da política, como na produção do campo da saúde coletiva, especialmente a partir de três categorias: modelos de atenção, financiamento e avaliação.

0 tema dos modelos de atenção foi objeto de estudos ao longo da trajetória histórica do SUS e das suas políticas. A academia buscava avaliar a implementação dos modelos propostos pelas políticas ou dos modelos que foram sendo inventados a partir de diferentes experiências locais - isso também é afirmado no encontro com muitos estudos sobre experiências tanto locais como regionais.

O tema do financiamento é constante no conjunto dos textos das políticas, havia um grande desafio em construir mecanismos de financiamento que pudessem dialogar com o modelo de produção da política no território. Ao mesmo tempo que o tema do financiamento mais geral para o SUS também era um desafio, o financiamento específico dessa política também se apresentava como mais um dos desafios. Como havia o desafio de produzir um modelo de financiamento que, ao mesmo tempo, incentivasse o conjunto de gestores a repensar a forma de organização da atenção a partir da perspectiva do fortalecimento da atenção básica como estratégia, também havia o desafio de pensar o financiamento na perspectiva da descentralização apesar da estrutura do Estado. Apesar desse tema ser um grande desafio para a política e seus textos produzidos, não se configurou como tema específico muito estudado pela academia, o financiamento mais geral, sim, mas o financiamento específico da atenção básica, não. 
O tema da avaliação é abordado pela academia (teses, dissertações e também a partir dos artigos publicados nos periódicos) de forma relevante entre 2008 e 2012, mais recentemente, e pode evidenciar a intencionalidade, identificada em muitas das produções, de avaliar a implementação das políticas, produzindo estudos avaliativos, em geral, focados em algum dos dispositivos da política, ou, em alguma ação específica, ou, em algum serviço, equipe ou município. Esse tema não aparece na formulação das políticas de forma marcante, somente por meio de algumas iniciativas pontuais que a política propõem enquanto dispositivos, como é o exemplo do AMAQ e do PMAQ. Contudo, apesar de servirem de referência para política, não conseguem ser plenamente incorporados na política, são dispositivos da política e não diretriz.

Outros temas foram objeto de estudo pela academia, observados tanto nas teses e dissertações, como nos artigos, como por exemplo o tema do trabalho (abordando o tema da equipe, do processo de trabalho, dos agentes comunitários de saúde e da atuação de alguma categoria profissional específica), o tema da Atenção Básica e as redes de cuidado (abordando o tema das ações programáticas, da diversificação das ações de cuidado, da produção do cuidado e do acesso as ações e serviços de saúde). Esses temas foram os que apresentaram mais ocorrências de produções do campo da saúde coletiva, especialmente no período entre 2008 e 2013. Esses temas são interessantes ao debate da política, no entanto, de forma geral, os estudos encontrados apresentam um olhar que é avaliativo descritivo de experiências específicas.

Apesar de perceber que as produções do campo da saúde coletiva, em geral, não apresentam questões de interesse do plano da produção da política e, portanto, influência na sua própria produção, podemos perceber que existem relações entre ambos os planos. Por exemplo, quando a política é formulada e instituída, notam-se estudos que abordam esse tema, incorporam seus conceitos e demonstram haver relação direta no estudo com a política em questão.

A percepção sobre o que está sendo estudado demonstra que as perguntas pesquisadas não apresentam relação direta nem com o enfoque dos textos das políticas e nem com as perguntas percebidas na produção das políticas a partir dos desafios postos a elas. Para observarmos de forma gráfica esse movimento, vamos observar as Linhas do Tempo construídas. 
芩

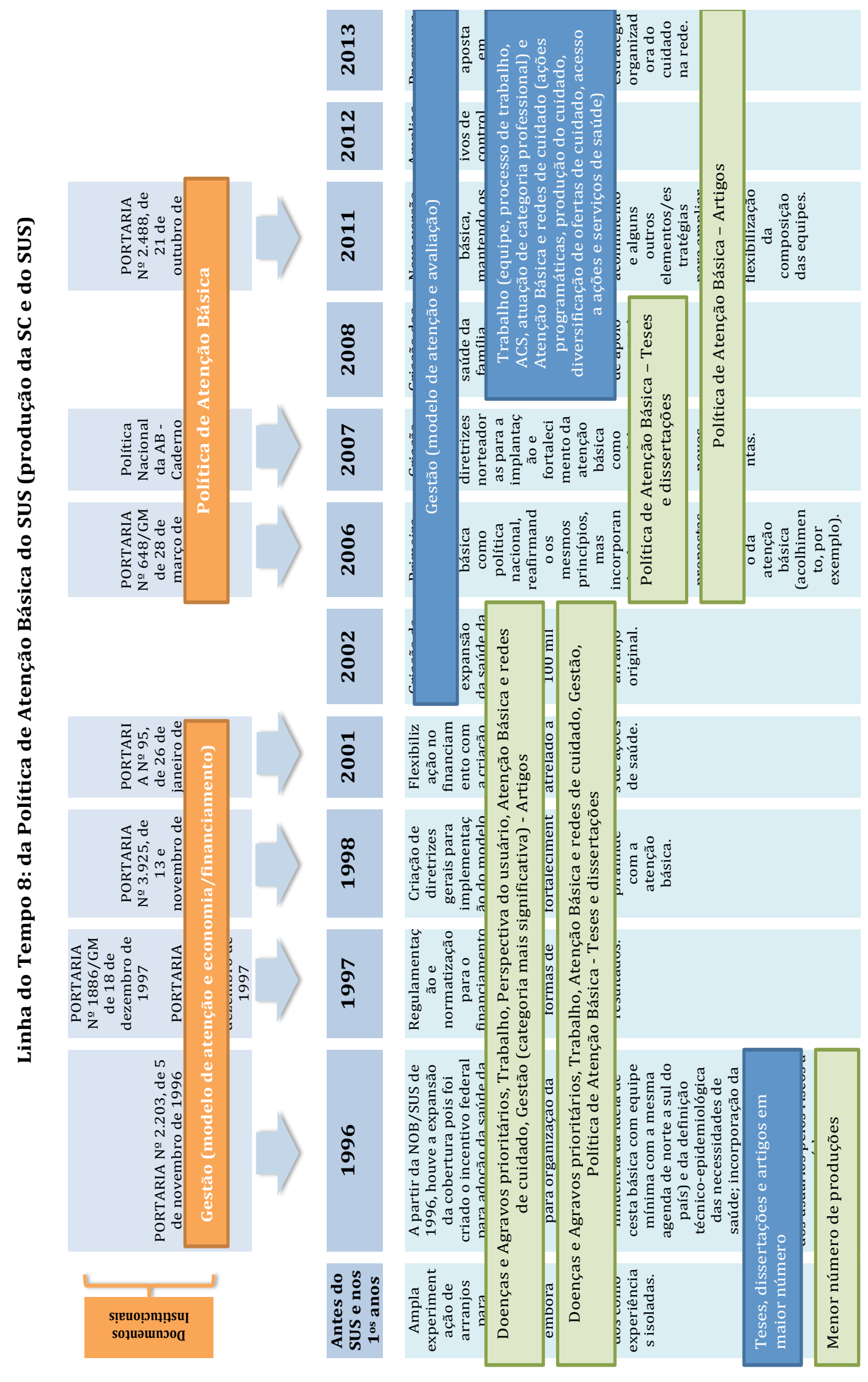




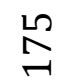

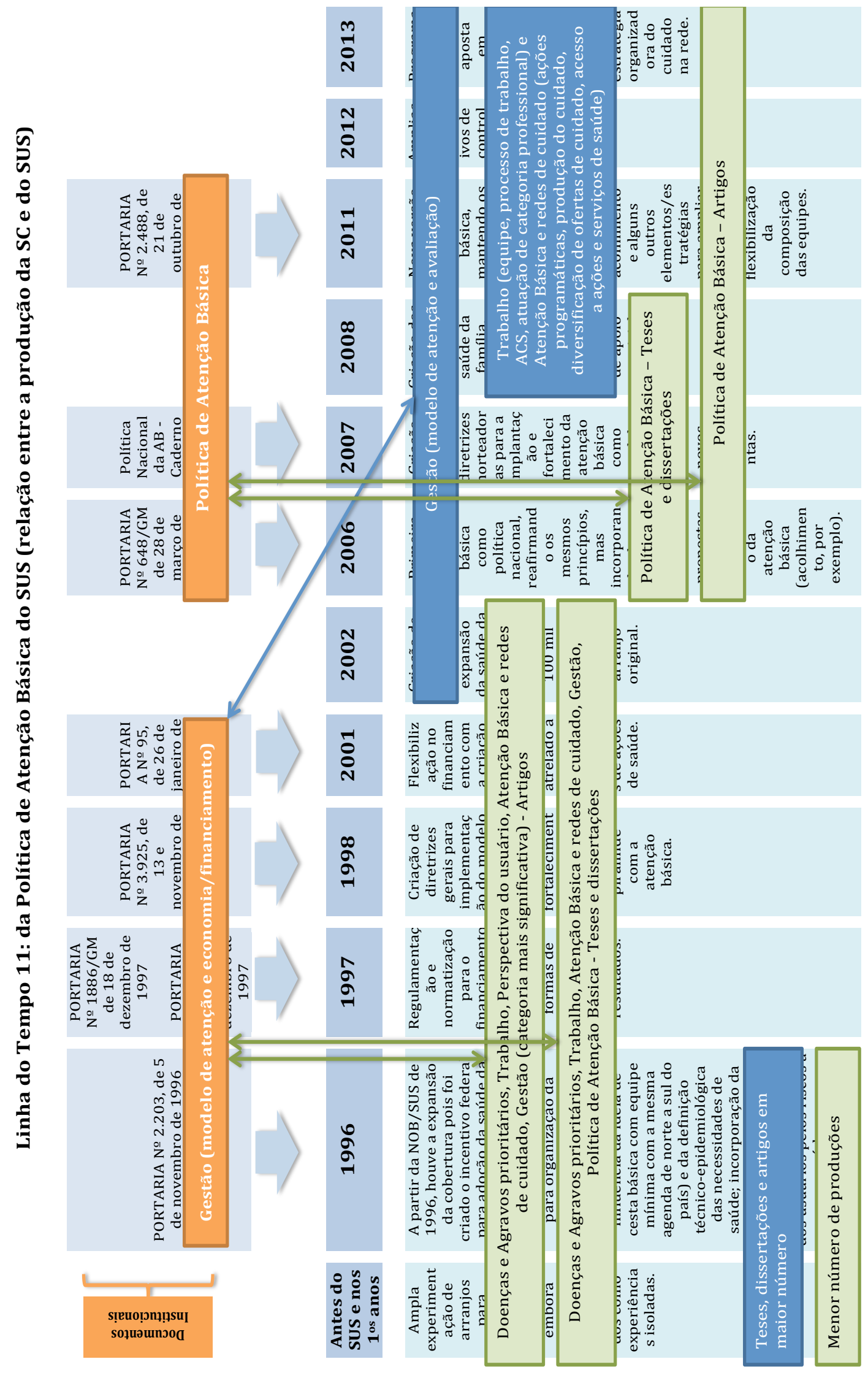




\section{Política de Regionalização e Organização do SUS}

No contexto geral da produção do campo, observando as teses, as dissertações e os artigos, notamos que as diferentes categorias temáticas referentes a política de regionalização e organização do SUS apresentam movimentos bem diferentes, conforme é possível observar no gráfico abaixo.

Gráfico 9: Distribuição das teses, dissertações e artigos selecionados por categoria temática da Política de Regionalização e Organizacão do SUS, segundo ano de ocorrência

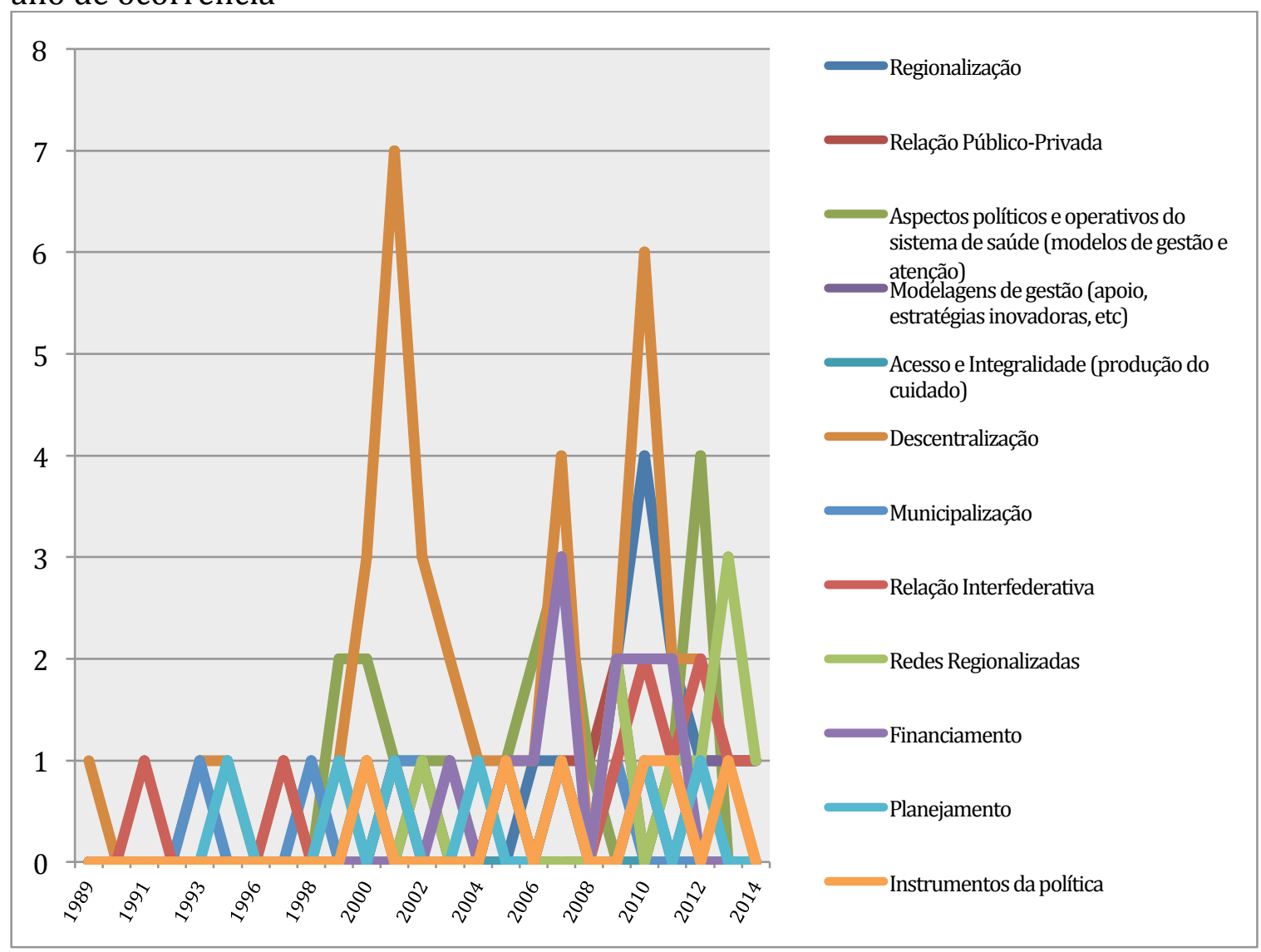

Foram estudados 68 teses e dissertações e 71 artigos com categoria prioritária relacionada a regionalização/organização do SUS, sendo que a principal categoria estudada é a descentralização. Nas teses e dissertações também aparece a categoria aspectos políticos e operativos do sistema de saúde (modelos de gestão e atenção). 
Gráfico 10: Distribuição dos artigos selecionados por categoria temática da Política de Regionalização e Organização do SUS, segundo ano de publicação

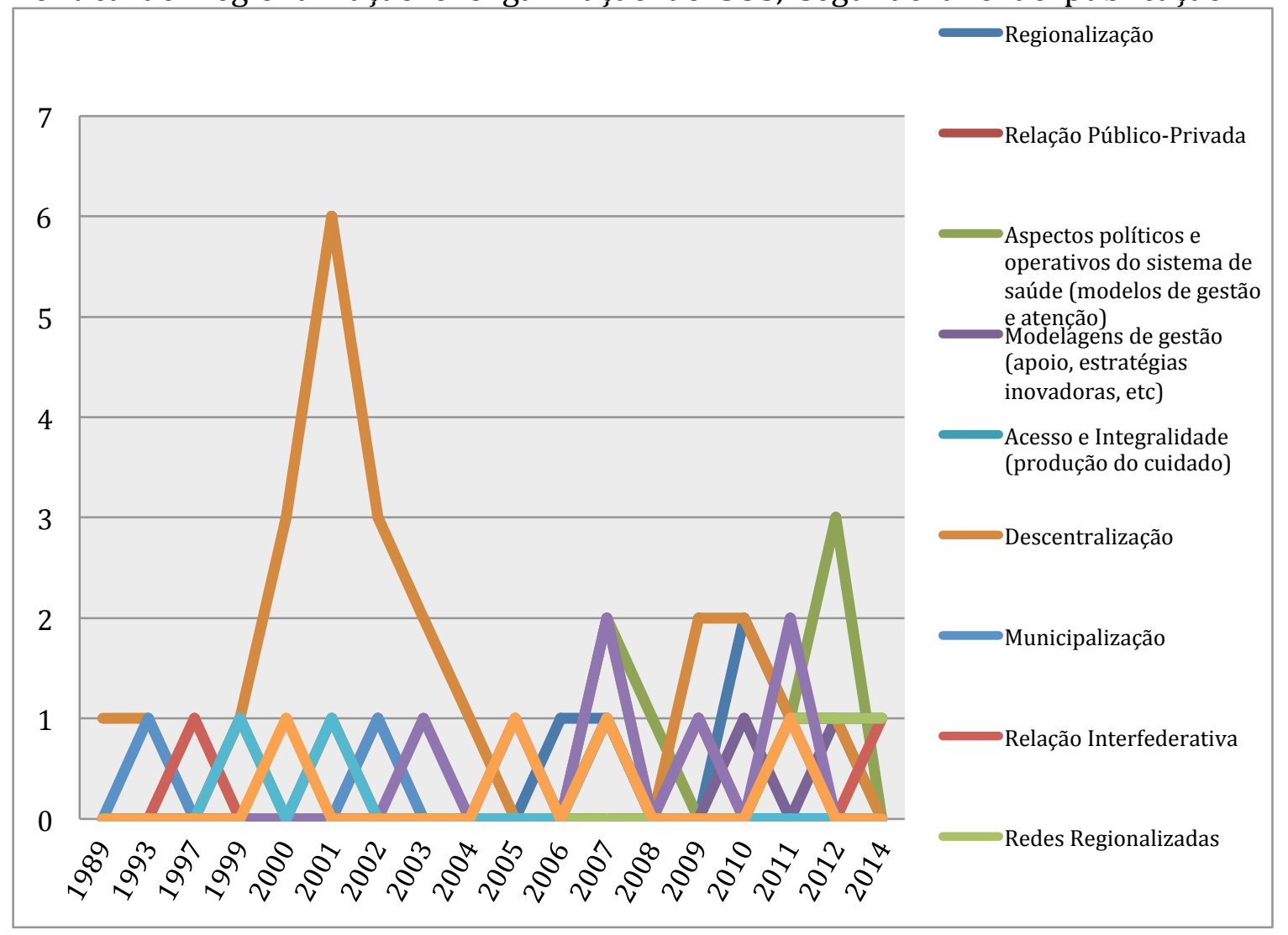

A partir dessa representação gráfica é possível perceber a predominância na publicação de artigos da categoria da descentralização, especialmente entre 2000 e 2004 e posteriormente entre 2009 e 2011. Os aspectos políticos e operativos do sistema de saúde e o financiamento também aparecem. Esses temas, a princípio, são de interesse para publicação.

Vamos observar qual o movimento das teses e dissertações. 
Gráfico 11: Distribuição das teses e dissertações selecionadas por categoria temática da Política de Regionalização e Organização do SUS, segundo ano de defesa

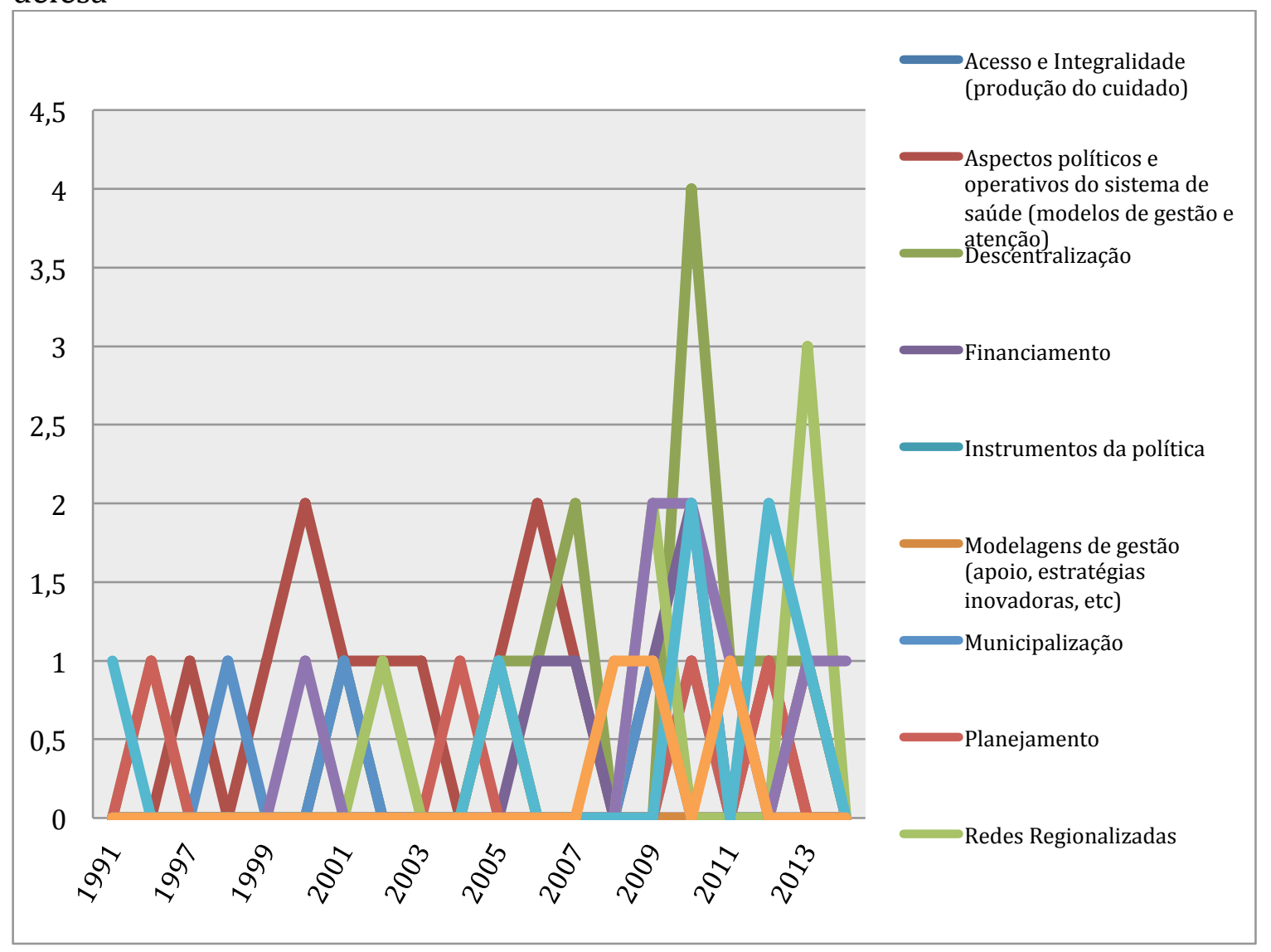

A descentralização continua sendo a categoria principal, com um pico no ano de 2010. Posteriormente, as redes regionalizadas tem uma produção relevante em 2013, assim como o planejamento em 2000 e em 2006.

Se observadas essas categorias, veremos que:

1. Descentralização:

a. Artigos são publicados entre 1999 e 2003 e entre 2008 e 2012.

b. Teses e Dissertações entre 2005 e 2007 e entre 2010 e 2013.

2. Aspectos politicos e operativos do sistema de saúde (modelos de gestão e de atenção):

a. Essa categoria somente aparece como relevante nas teses e dissertações no período entre 2000 e 2007.

São desafios enfrentados ao longo da construção do SUS e objeto de políticas que apresentam descontinuidades, não necessariamente captadas nos estudos realizados. 
Do total das produções de artigos, teses e dissertações estudadas, nota-se um aumento mais significativo no número de produções em 2001, 2007 e 2010.

Gráfico 12: Distribuição das produções selecionadas da Política de Regionalização e Organização do SUS por tipo de produção segundo ano ocorrência

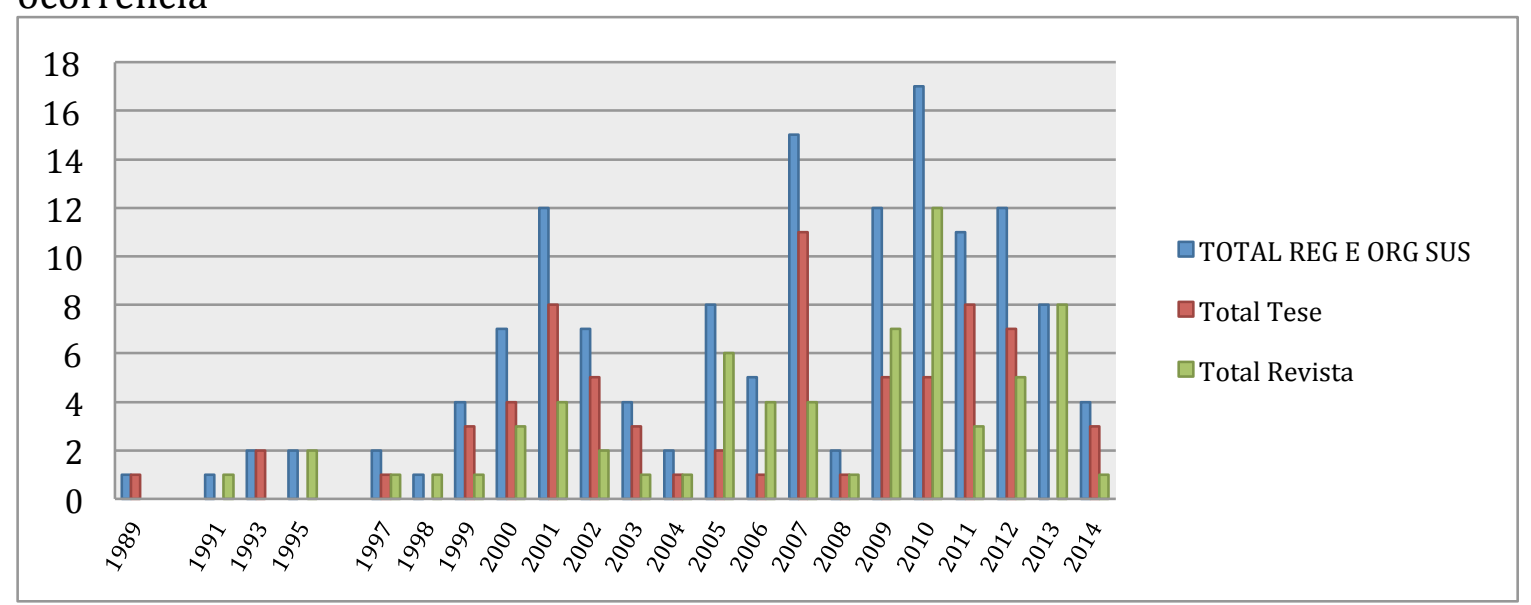

Diferenças entre revistas e programas de pós também acontecem aqui. Podemos destacar:

1. Revista de Saúde Pública da USP: não apresenta número significativo de artigos sobre essa política.

2. Revista Ciência e Saúde Coletiva:

a. Descentralização foi a categoria mais relevante nessa revista.

3. Cadernos de Saúde Pública:

a. Também teve a categoria da descentralização como a mais relevante.

Diferentes apostas e linhas editoriais entre os periódicos refletem-se na quantidade de artigos encontrados. 
Gráfico 13: Distribuição dos artigos selecionados da Política de Regionalização e Organização do SUS segundo periódico

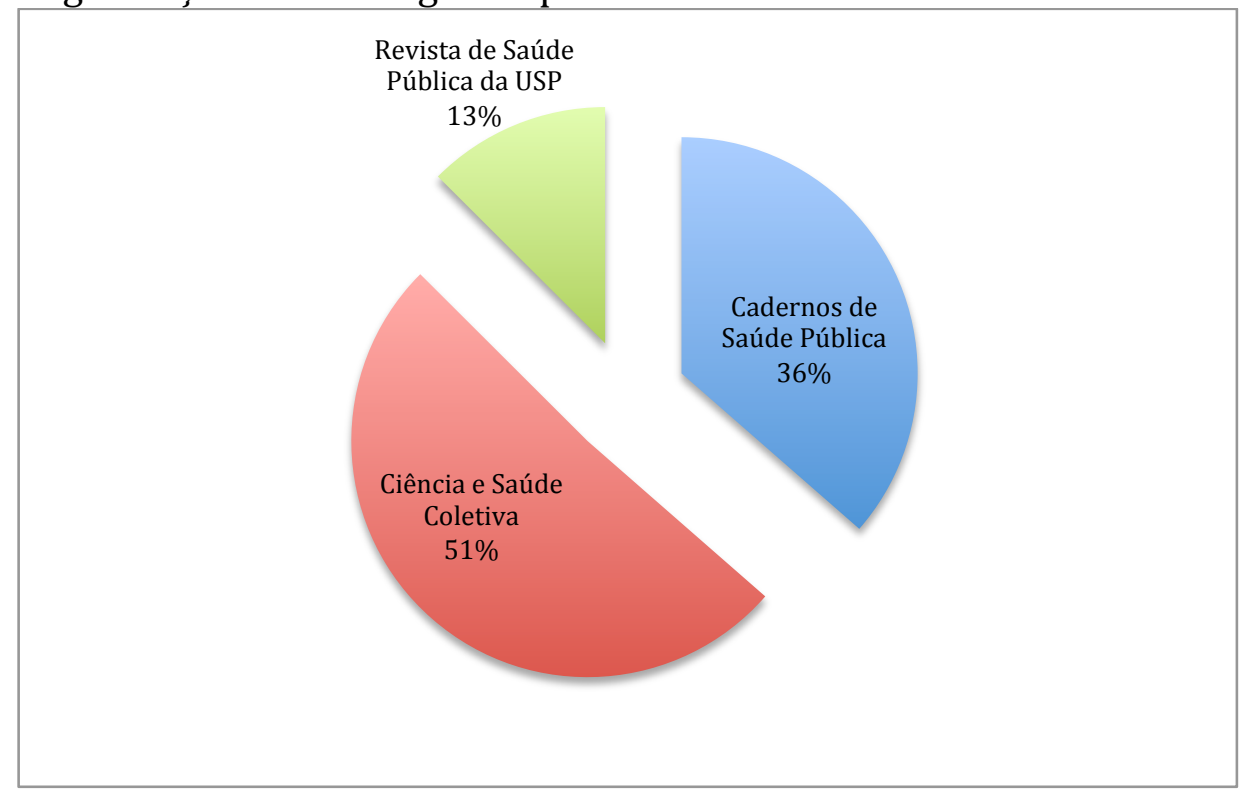

Entre os programas:

1. UNICAMP:

a. A categoria aspectos políticos e operativos do sistema de saúde (modelos de gestão e de atenção) é estudada com uma certa relevância.

b. Redes Regionalizadas é outra categoria estudada.

2. MPREV USP:

a. Regionalização é a principal categoria estudada.

3. ISC UFBA:

a. A principal categoria estudada é a regionalização.

4. IMS UERJ:

a. Aspectos políticos e operativos do sistema de saúde (modelos de gestão e de atenção)

b. Financiamento

5. FSP USP:

a. Descentralização

6. ENSP:

a. Descentralização

Percebe-se que sobre essa política não existe muita linearidade na produção entre os periódicos e nem entre os diferentes programas de pós-graduação, cada 
um fez sua aposta e, apesar de ser uma política estruturante do SUS e presente desde sua criação, não encontramos uma tendência ao estudo dela que demonstre linearidade e continuidade.

Observando a política de regionalização e organização do SUS, bem como esse movimento conceitual que foi produzido pelas produções do campo, observamos relação entre os temas da produção das políticas e do campo. Alguns temas são encontrados desenvolvidos em ambos os planos, tanto nas formulações da política como nas teses, dissertações e artigos do campo. São esses temas: regionalização, financiamento, descentralização, relação intefederativa e instrumentos da política. Todos esses temas permearam, ao longo dos anos, as diversas produções estudadas. Quando observamos mais atentamente as produções, verificamos que muitos estudos sobre essa política são teóricoconceituais, as abordagens são sobre as referências teóricas que discorrem sobre tais temas. Essa reflexão é relevante para o amadurecimento dos conceitos que são utilizados como base da formulação das políticas mas nem sempre dialogam com as questões que o sistema traz. Por exemplo, o tema da descentralização, que é o que apresenta a maior frequência de produções do campo, não apresentou formulações relevantes e/ou com capacidade de capilaridade para influenciar o sistema de saúde, isso percebe-se pela própria fragilidade nas formulações sobre o tema no contexto e nos textos das políticas.

É importante lembrar que a política de regionalização e organização do SUS, dentre as 3 estudadas, foi a política que apresentou o maior número de formulações de textos políticos, ao mesmo tempo que foi o tema com menor número de produções da academia. Esse movimento pode ser observado devido ao desafio posto ao SUS para produção de estratégias e de dispositivos potentes para a regionalização e a organização do maior sistema universal de saúde do mundo, o SUS. Da mesma forma, isso também é demonstrado pelas produções do campo, que tem dificuldade de questionar a política e de produzirem movimentos propositivos.

O tema da regionalização é constante na produção da política contudo se apresenta somente a partir de 2006 nas produções do campo, com maior ocorrência nos artigos publicados nos periódicos. Esse tema é uma das diretrizes do SUS e ao mesmo tempo a referência conceitual de toda organização do modelo de atenção à saúde. Também, sendo conceito estruturante da própria 
organização geopolítica do país, pode ser percebido como tema fundante dessa própria política aqui destacada. A produção do campo que aborda tal tema é mais recente no entanto, anteriormente, os temas descentralização e municipalização traziam consigo alguns enfoques que apresentavam similaridades e que podem ser observados mesmo anteriormente a 2002.

0 tema do financiamento é abordado de forma permanente no conjunto dos textos da política bem como nas ações produzidas pela política, no entanto, é tema das produções no campo no período entre 2006 e 2011. Ele parece ter sido influenciado pelos movimentos que vinham acontecendo no sistema de saúde pois a produção de estudos aumenta a partir do período em que começa a vigorar o mais importante movimento de mudança do financiamento no SUS, a partir de 2006. Esse tema, que sempre foi um grande desafio para a produção da política, não apresentou tantos estudos no campo, no entanto, traz análises e formulações críticas considerando problemas estruturantes e localizados em relação a necessidade de recursos para viabilização do SUS em todo país.

0 tema da descentralização não é tema constante das políticas já que se coloca como diretriz geral do sistema como um todo, mas se apresenta, ao longo dos anos, nas produções do campo, sendo percebido de forma mais relevante, tanto nos artigos como nas teses e dissertações, no período de 2002 a 2013. A descentralização que também é uma das diretrizes do SUS, tema recorrente no conjunto das formulações políticas, também foi objeto de muitos estudos e producões do campo.

Outro tema que é muito presente na produção dos textos e dos movimentos politicos é o da relação interfederativa, especialmente a partir de 1993, tanto com a abordagem para a articulação interfederativa como para os espaços colegiados do SUS. Esse tema é percebido nas produções do campo, não de forma permanente, percebe-se produções em período anterior a 1996 e depois de 2011 já quando o SUS regulamenta tal arranjo organizativo.

E, o tema dos instrumentos da política (normas, pacto e decreto) apesar de ser tema freqüente na produção dos textos das políticas, não é um tema objeto de produções do campo da saúde coletiva.

Aspectos políticos e operativos do sistema (modelos de gestão e atenção) foi outro tema que foi abordado ao longo dos anos. Não é um tema relevante devido ao volume de producões mas é interessante e, a não identificação dele enquanto 
tema principal dos textos da formulação da política também é uma informação relevante. Percebe-se o descolamento no tratamento conceitual desse tema pelo conjunto das políticas, ou seja, apesar de ser tema relevante na política de atenção básica, não se constitui da mesma forma nessa política. Isso também é demonstrado pelo próprio fato de que não houve a regulamentação do SUS até 2011, o que poderia auxiliar no fortalecimento da política. Sendo assim, compreende-se que essa política estruturou-se a partir de diretrizes e propostas que a sustentaram ao longo de 20 anos, e, por isso, tantos textos e propostas diferenciadas foram sendo produzidas nesse tempo, no entanto, seus textos infra-legais não fortaleceram o próprio sistema, foram sendo experimentações que froam sendo produzidas ao longo desse tempo.

Assim, percebe-se relação entre ambos os planos de produções, contudo, somente a partir de alguns movimentos pontuais. Por exemplo, o movimento de produzir mais estudos sobre o tema da descentralização, acentuou-se quando o próprio sistema produziu mais dispositivos para efetivar tal diretriz, especialmente com a organização da proposta do modelo de atenção à saúde da família. Também observou-se que nesse mesmo período, também aumentaram as produções do campo sobre os aspectos políticos e operativos do sistema (modelos de gestão e atenção), o que pode ser também influência dessa novidade no sistema que buscou organizar a atenção mas também ao esgotamento do modelo de gestão que não estava dando resultados concretos para o fortalecimento do próprio sistema, especialmente se considerarmos as limitações nas relações público-privadas, no uso da Lei de Responsabilidade Fiscal, no financiamento e nas relações interfederativas e os processos de pactuação e co-responsabilização.

Abaixo podemos observar esse movimento conceitual de forma gráfica a partir das Linhas do Tempo construídas da Política de Regionalização e Organização do SUS. 


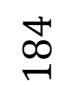

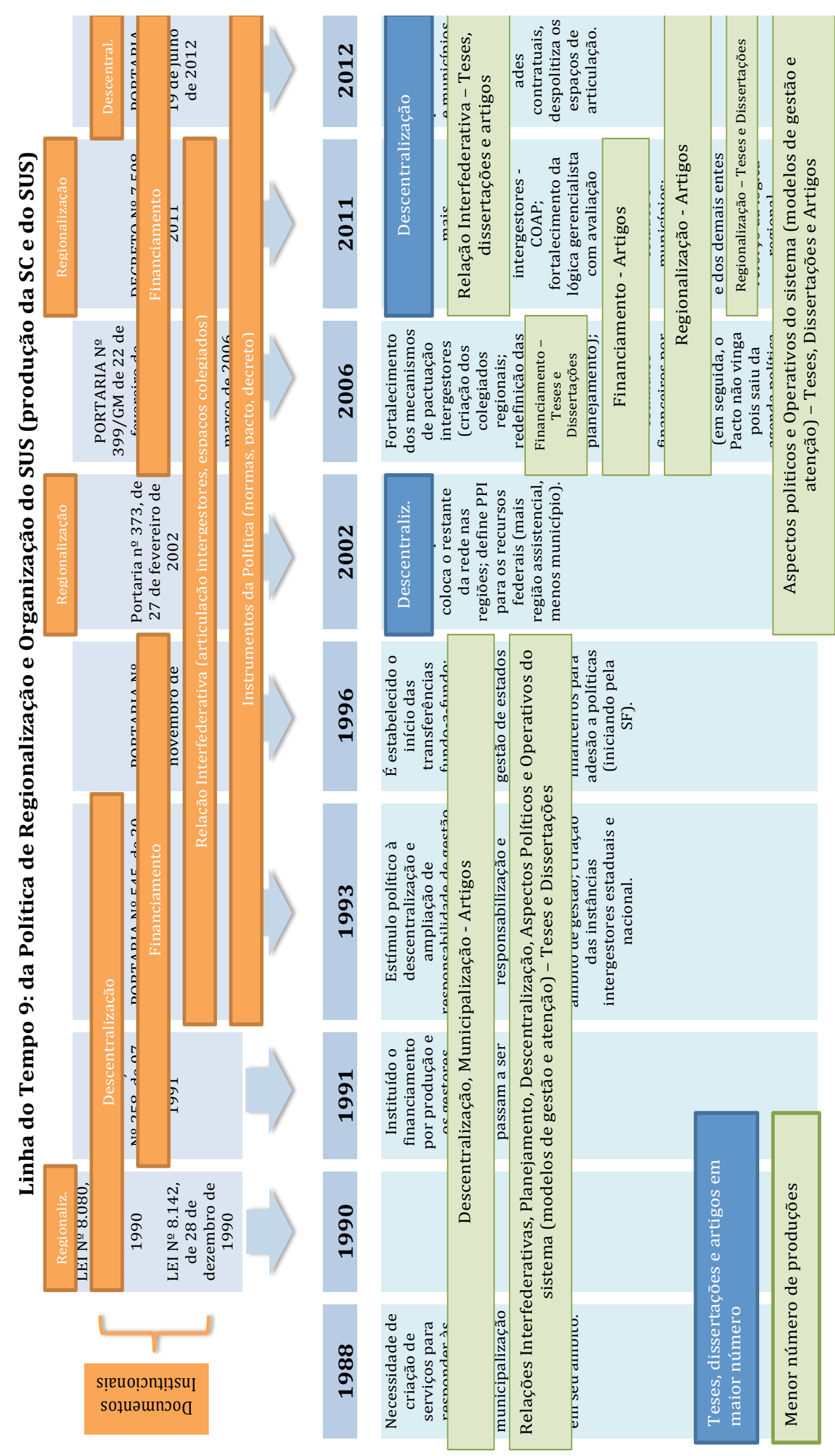




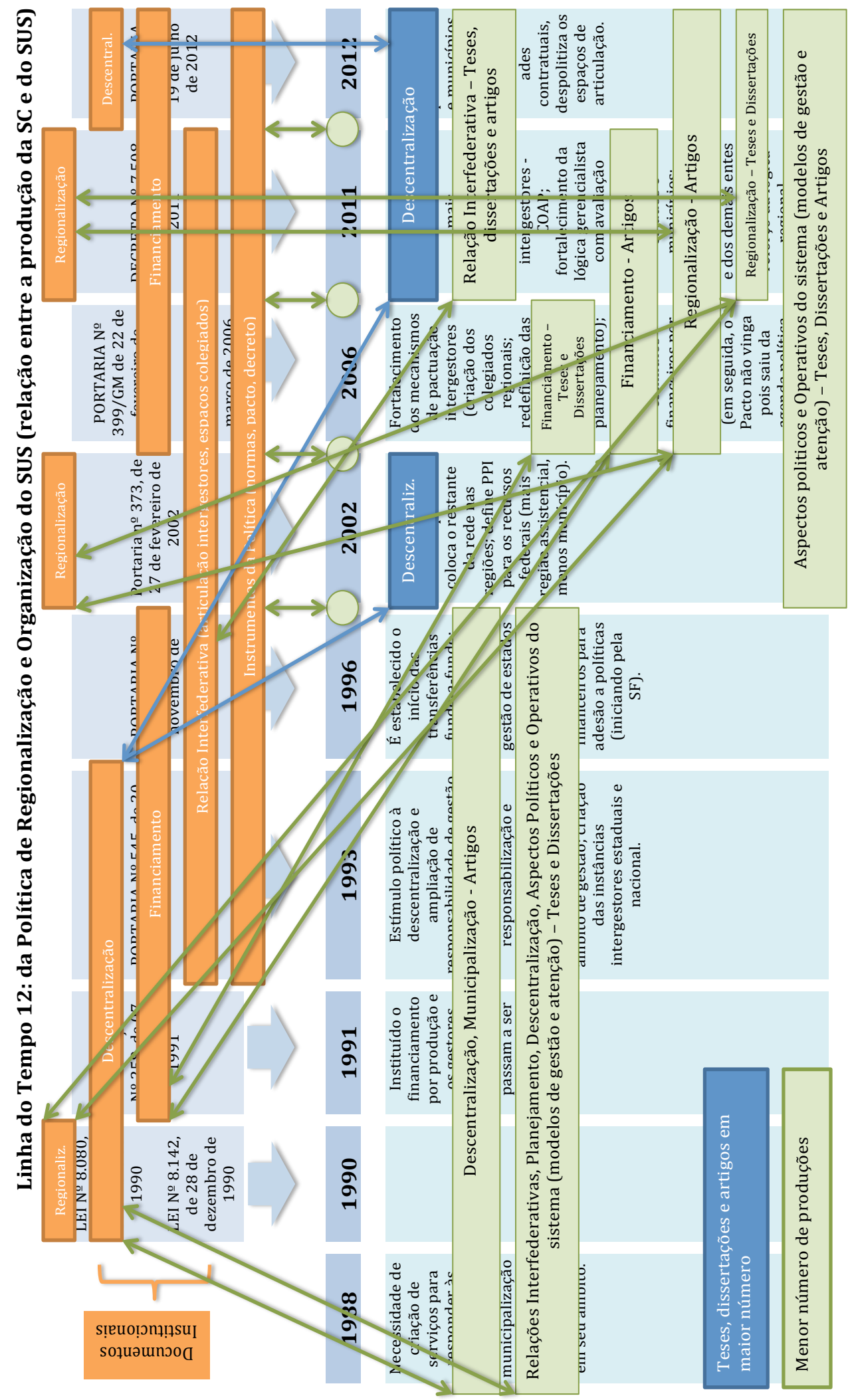




\section{Política de Educação na Saúde}

No contexto geral da produção do campo, observando as teses, as dissertações e os artigos, notamos que as diferentes categorias temáticas apresentam movimentos bem diferentes, conforme é possível observar no gráfico abaixo.

Gráfico 14: Distribuição das teses, dissertações e artigos selecionados por categoria temática da Política de Educação na Saúde, segundo ano de ocorrência

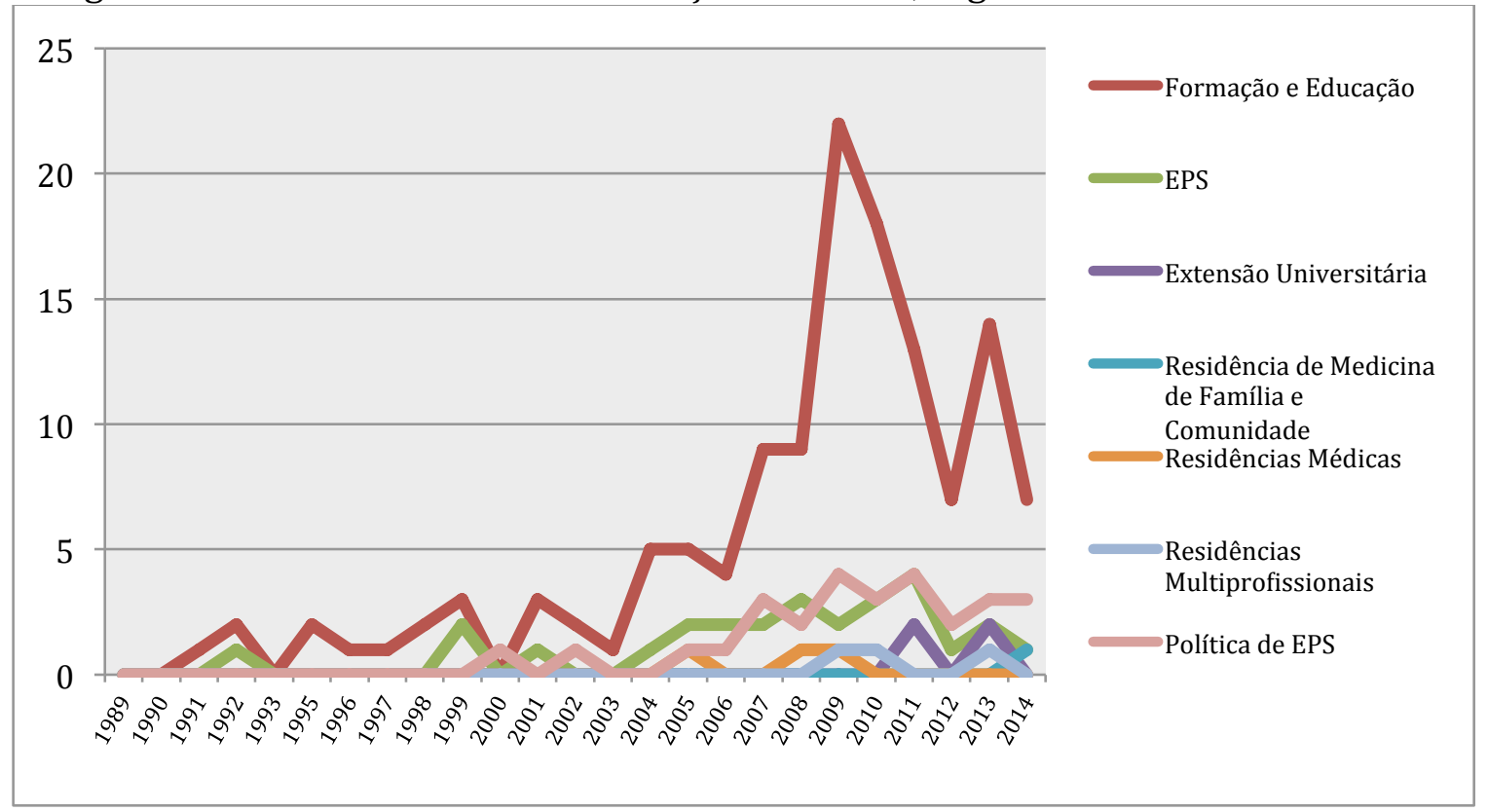

111 teses e dissertações e 86 artigos focaram como categoria prioritária a política de educação permanente. As categorias formação e educação, Educação Permanente em Saúde (EPS) e da Política de EPS são as que mais se destacam. 
Gráfico 15: Distribuição dos artigos selecionados por categoria temática da Política de Educação na Saúde, segundo ano de publicação

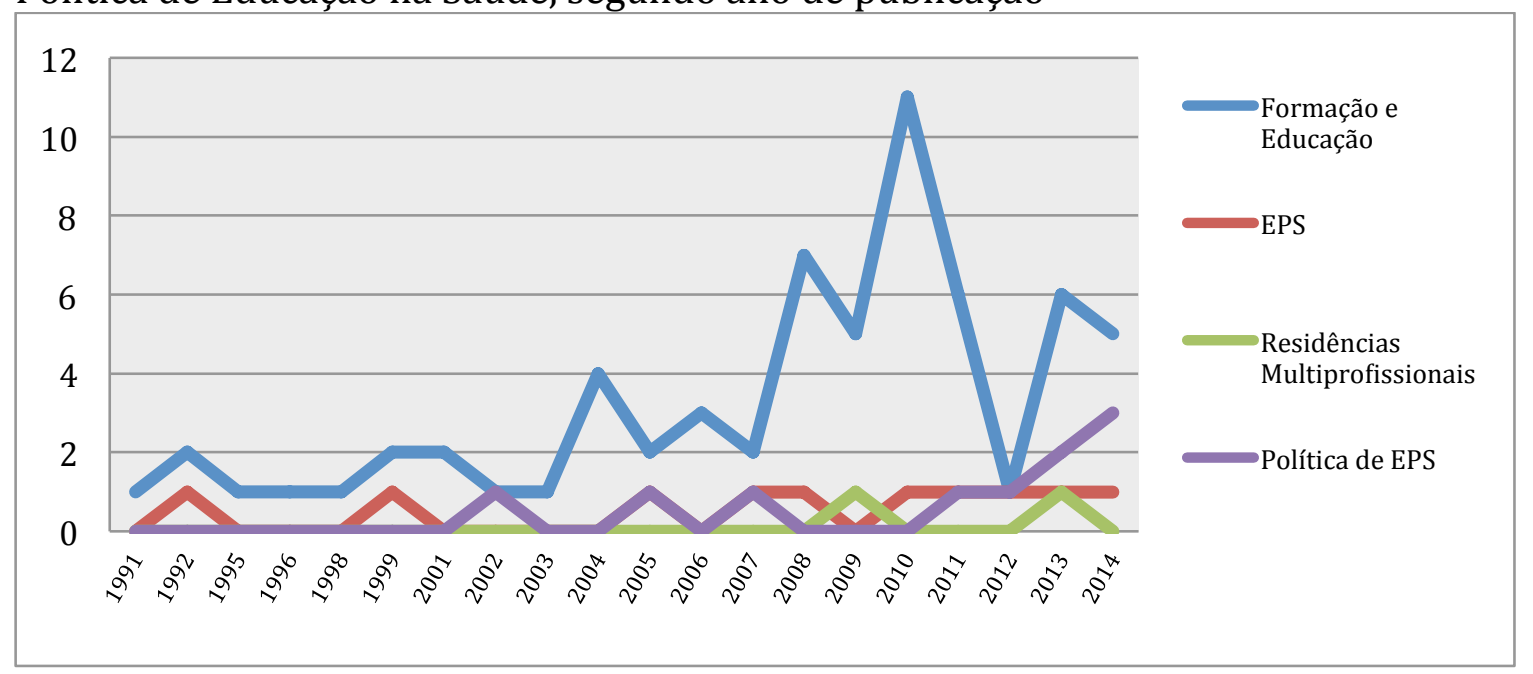

Percebe-se que os artigos majoritariamente abordam temas ligados a categoria Formação e Educação, especialmente a partir de 2004, ano em que foi lançada a política nacional de educação permanente em saúde, tendo um pico em 2010.

Conforme já comentado, antes de haver política nessa área, havia intensa mobilização e experiências de mudança na formação disparadas e estudadas a partir dos movimentos. Isso explica a produção constante sobre o tema. A intensificação provavelmente tem a ver com as políticas - a partir de 2003 e 2004 e depois com o pro e pet saúde. A Política de EPS foi objeto de vários estudos, provavelmente mobilizada pelas novidades e estranhamentos que suscitou. 
Gráfico 16: Distribuição das teses e dissertações selecionadas por categoria temática da Política de Educação na Saúde, segundo ano de defesa

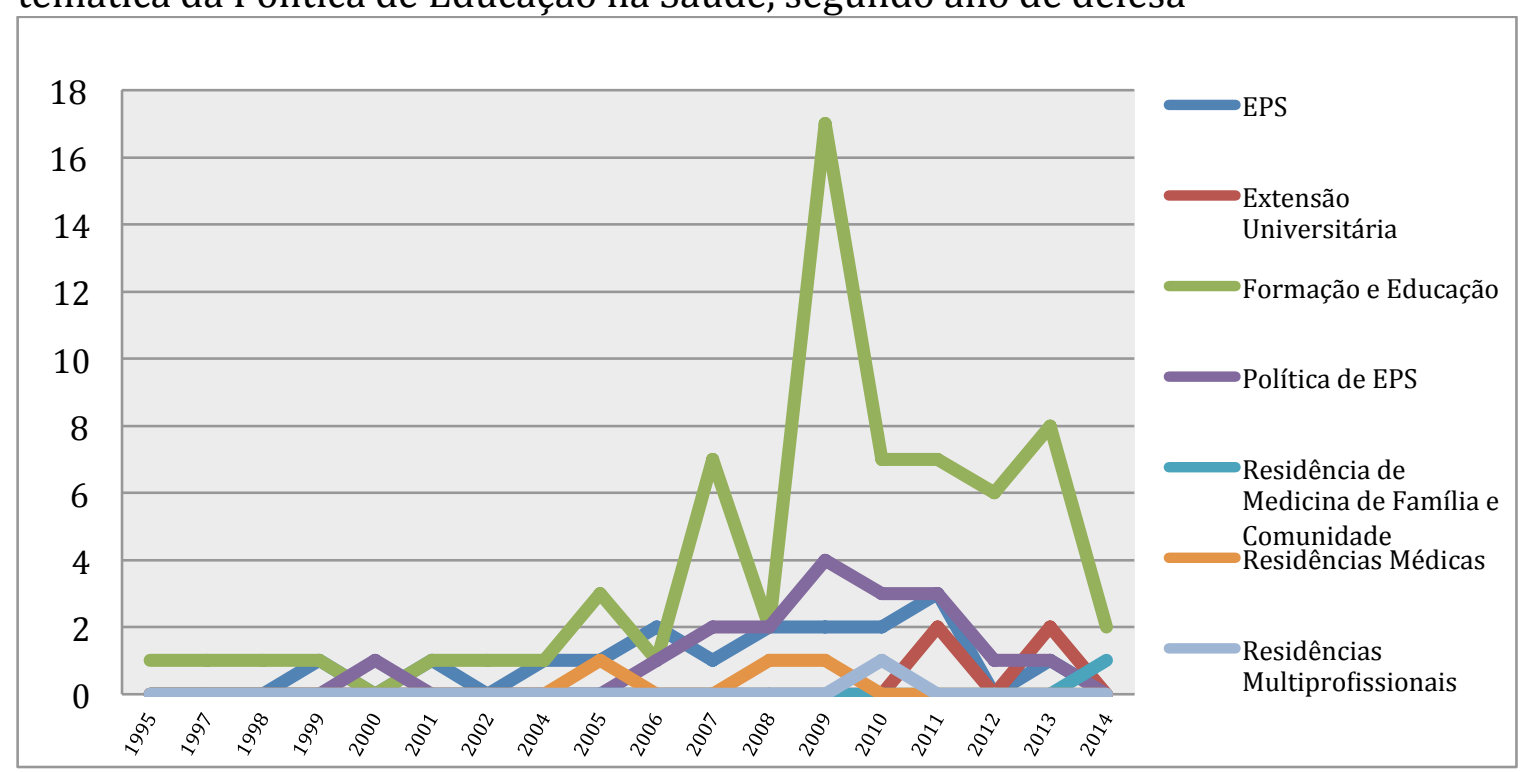

Apesar de a distribuição apresentar algumas diferenças no tempo, o movimento é semelhante. Formação e Educação, Política de EPS e depois Residências.

Se observadas essas categorias, veremos que:

1. Formação e Educação:

a. Artigos são publicados entre 1998 e 2014, com maior concentração entre 2008 e 2014, com as seguintes sub-categorias:

2. Graduação: entre 2008 e 2011, maior concentração em 2008

3. Avaliação da Formação: entre 2008 e 2014, no ano de 2010 maior concentração

4. Experiências de Formação: entre 2002 e 2009, maior concetração neste último

5. Diversificação dos cenários de prática: entre 2009 e 2014, maior concentração em 2011

6. Teses e Dissertações defendidas entre 2004 e 2014, com maior concentração em 2009, com as seguintes sub-categorias:

a. Avaliação da Formacão: entre 2007 e 2013, concentração em 2009

b. Experiências de Formação: entre 2008 e 2013, concentração em 2009

O tema da formação e educação é o principal tema do desenvolvimento das produções do campo ao longo dos anos, intensificando-se após a política . 
A Educação Permanente em Saúde se apresenta como tema prioritário em teses e dissertações entre 2004 e 2011 mas sem afirmar nenhuma sub-categoria em especial. Política de EPS também é um tema prioritário em algumas teses e dissertações no período entre 2006 e 2013, sendo que em 2009 há maior concentração. Essa tendência tem relação direta com a produção da política, construída em 2004.

Gráfico 17: Distribuição das produções selecionadas da Política de Educação na Saúde por tipo de produção segundo ano ocorrência

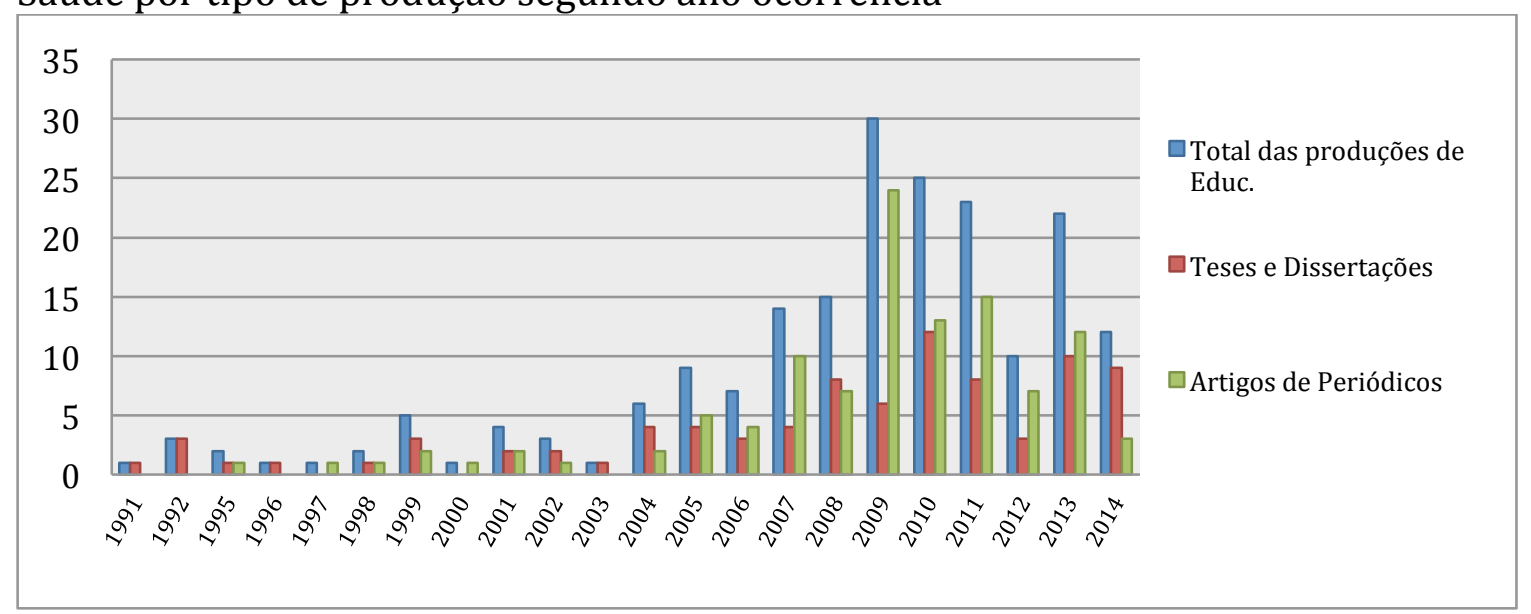

Se observadas as categorias temáticas, percebemos uma grande diferença entre os periódicos e entre os programas de pós-graduação. Podemos destacar:

1. Revista de Saúde Pública da USP: apresenta poucos artigos sobre política de educação na saúde.

2. Revista Ciência e Saúde Coletiva:

a. A principal categoria estudada foi a formação e educação a partir das sub-categorias: graduação, avaliação da formação e diversificação dos cenários de prática.

3. Cadernos de Saúde Pública: apresenta poucos artigos sobre política de educação na saúde.

0 gráfico abaixo mostra essa distribuição. 
Gráfico 18: Distribuição dos artigos selecionados da Política de Educação na Saúde segundo periódico

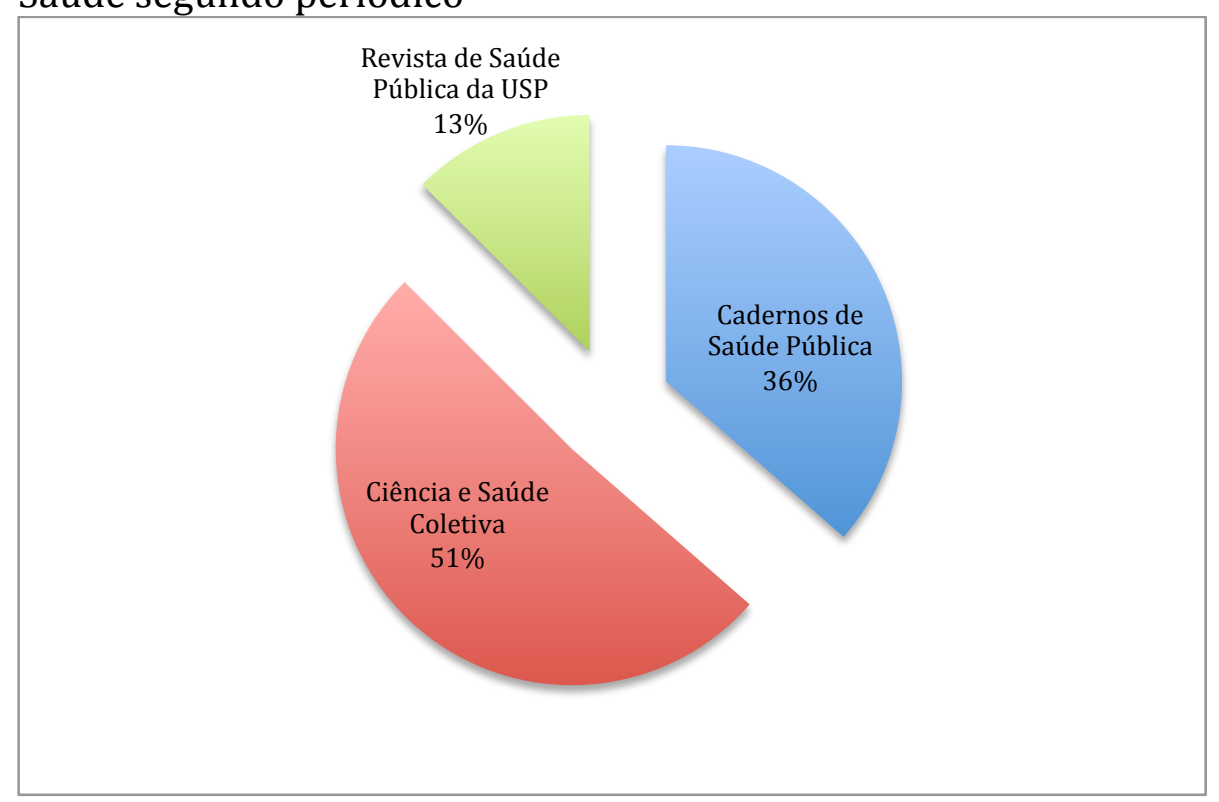

Em relação às teses e dissertacões também ficam evidentes apostas e intencionalidades:

1. UNICAMP:

a. A principal categoria estudada foi a formação e educação por meio de duas sub-categorias: graduação e experiências de formação.

2. MPREV USP:

a. A principal categoria estudada também foi a formação e educação mas a sub-categoria que mais é abordada é o desenho curricular.

3. ISC UFBA:

a. Formação e educação é estudada por meio da sub-categoria avaliação da formação.

b. A categoria Educação Permanente em Saúde aparece aqui estudada especialmente a partir da sub-categoria EAD/Telessaúde/TI.

4. IMS UERJ:

a. A categoria extensão foi estudada por meio da sub-categoria extensão universitária.

b. A categoria política de EPS foi estudada a partir do estudo da subcategoria análise da política.

5. FSP USP:

a. A formação e educação foi a principal categoria estudada especialmente por meio da sub-categoria avaliação da formação. 


\section{ENSP:}

a. A principal categoria estudada foi a formação e educação a partir de duas sub-categorias: experiências de formação e avaliação da formação.

Esse movimento pode ser visualizado no gráfico abaixo.

Gráfico 19: Distribuição das teses e dissertações selecionadas da Política de Educação na Saúde segundo programa de pós-graduação

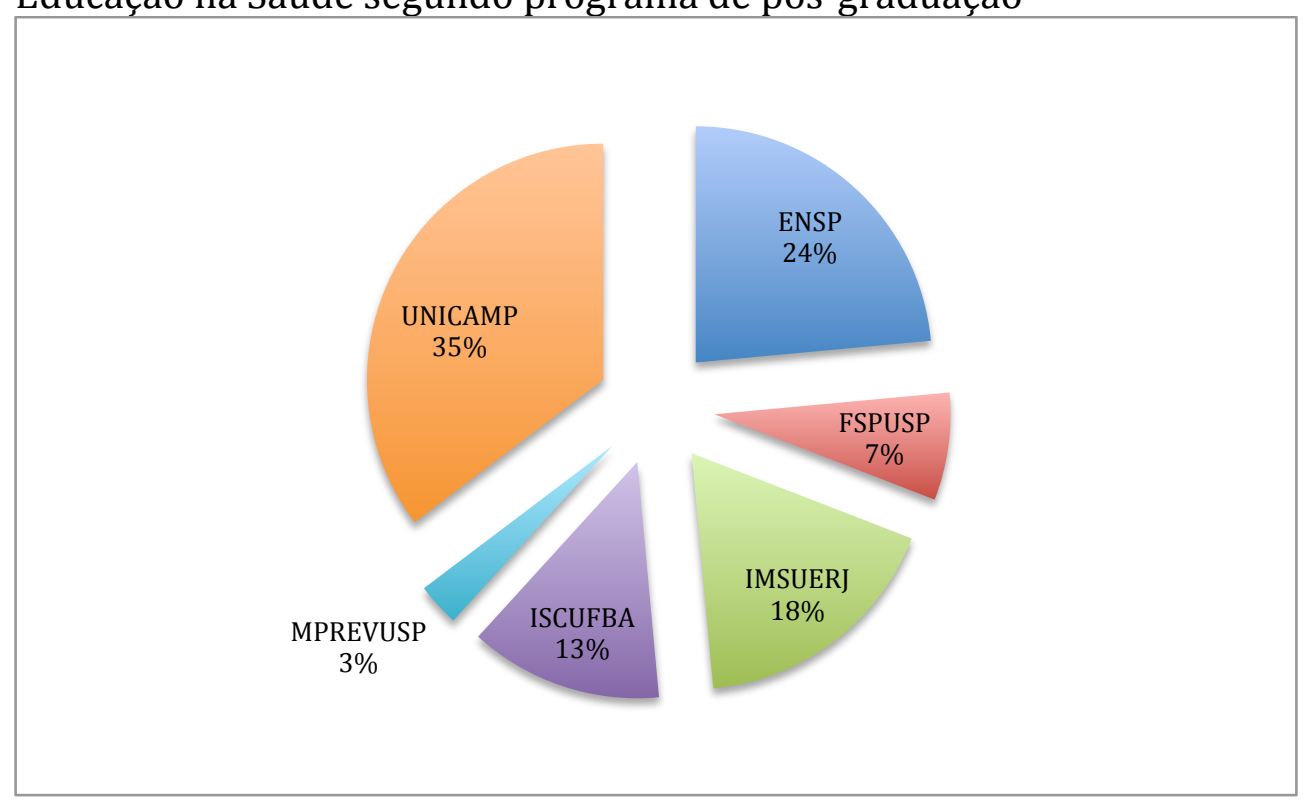

Observando a política de educação na saúde, percebemos sua temporalidade institucional limitada, pois, apesar dos temas que a compoem serem existentes no cenário do sistema de saúde, assim como no campo da saúde coletiva há muitos anos, enquanto política, e expressa em textos, somente passou a existir de forma mais sistematizada, e não somente por projetos ou iniciativas isoladas, a partir de 2004. E esse é o tema que está presente nos textos da política e que posteriormente passou a ser tema das produções do campo. Entretanto, o tema que mais está expresso no plano de produção do campo ao longo dos anos é o da formação e educação, especialmente abordando os seguintes temas específicos: graduação, avaliação da formação (aqui destacamos os estudos sobre os cursos ofertados, egressos e desconexão entre oferta e demanda de capacitações) e diversificação de cenários de prática (especialmente com o tema d ainclusão dos diferentes profissionais nos serviços de saúde, principalmente na atenção básica). 
Os diversos temas, problemas e desafios que embasaram a construção dessa política, em alguma medida, já existiam desde o início da construção do SUS e eram tema de estudos do campo, especialmente com enfoque na percepção de que a formação dos profissionais deveria ser modificada. Somente após 2003 é que esses temas viraram objeto de formulação de uma política específica no arcabouço legal do SUS. E, a partir dessa formulação, percebe-se que o tema da própria política também vira objeto das formulações do campo. Dessa forma, percebe-se que existiu relação entre as produções de ambos os planos. No caso específico dessa política, observa-se que as próprias formulações do campo, de certa forma, influenciaram e ambasaram alguns dos dispositivos da política. Contudo, o tema da política enquanto dispositivo, que se destacou na formulação dos seus textos politicos, não é percebido de forma relevante nas produções do campo. Assim como nas outras políticas, as produções do campo, de forma geral, apreendem-se dosconceitos e dos textos da política e os utilizam como referência para estudos e produções, com isso, as questões levantadas não necessariamente problematizam a política e produzem conhecimentos e propostas que possibilitem seu fortalecimento, elas tomam as políticas como referências, como algo dado.

Quando observamos mais atentos os movimentos conceituais que aconteceram ao longo dos anos a partir dos processos produtores da política, observamos que existem rupturas importantes, mudanças na formulação da política e dos seus dispositivos, no entanto, tais momentos não são percebidos na produção dos textos no campo da saúde coletiva. Existe uma certa linearidade nas produções com a incorporação das novas formulações da política do mesmo modo como antes, tomando-as como referência dos estudos e não as questionando.

Essa relação que se estabeleceu entre ambos os planos, não potencializou a utilização do próprio conceito de educação permanente como dispositivo no processo de produção das políticas. 0 que se percebe é que talvez a própria formulação dessa política com o nome de Política Nacional de Educação Permanente em Saúde tenha trazido, em certa medida, um pouco de confusão e banalização do próprio conceito já considerou muitos dispositivos como educação permanente.

Desse modo, a potência do conceito como dispositivo tanto para co-gestão como para produção compartilhada (das políticas, da gestão e do trabalho em saúde) 
foi sendo equiparado aos processos educativos, sejam os formais como também aos mais diversos formatos pedagógicos que foram sendo produzidos no SUS. Os processos educativos podem acionar movimentos de educação permanente dependendo de como forem disparados, mas isso não está dado e, por isso, o uso generalizado do conceito enfraquece sua potência como dispositivo para tranaformação das práticas, para produção de novos encontros e novas potencialidades. Essa visão é percebida no plano das produções do campo da saúde coletiva quando identificamos o uso do conceito em diversas produções que envolvem essa política.

Esse movimento conceitual observado tanto nas produções do campo como das políticas pode ser melhor visualizado, no aspect temporal, ao observarmos as Linhas do Tempo da Política de Educação na Saúde do SUS construídas. 


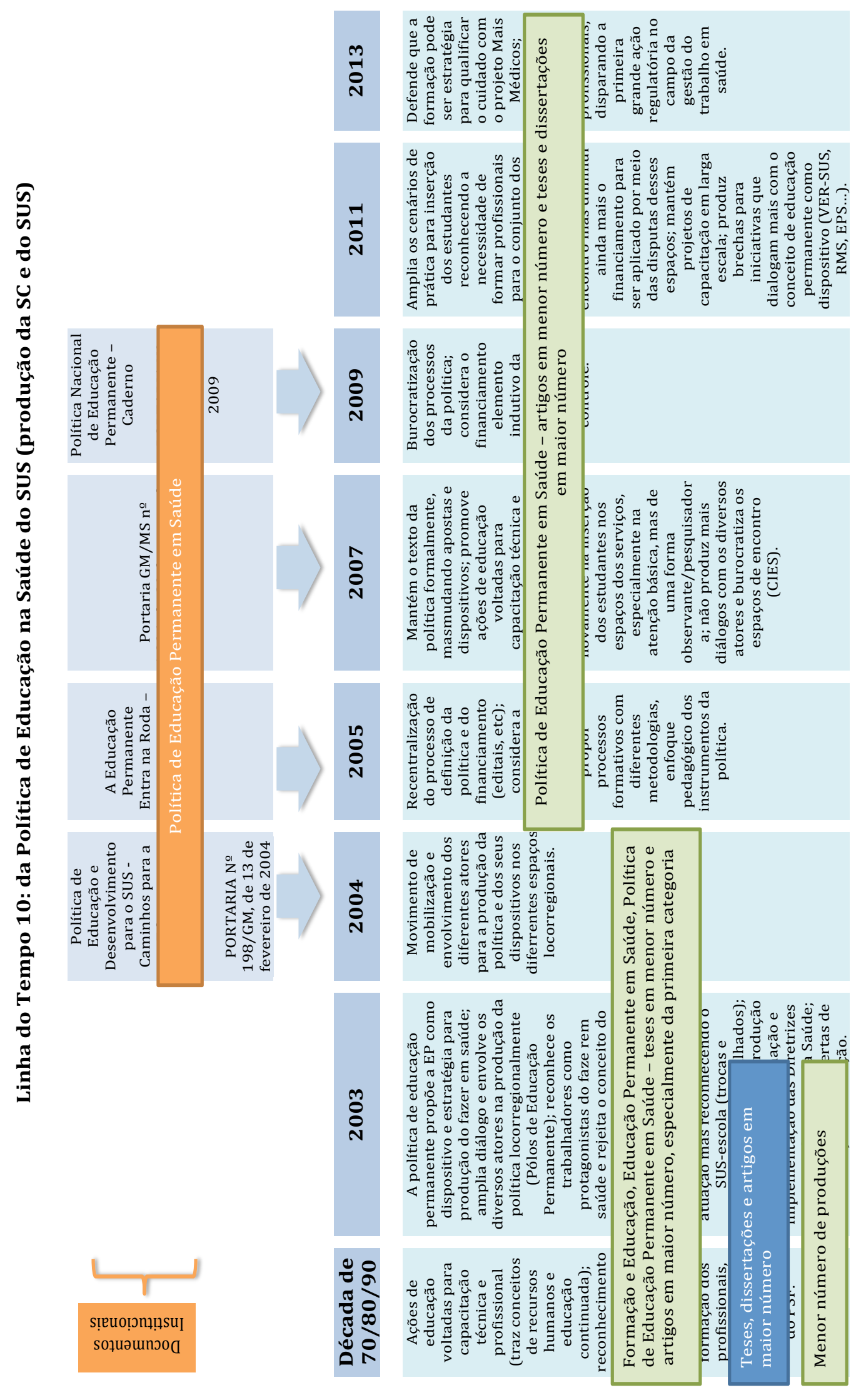




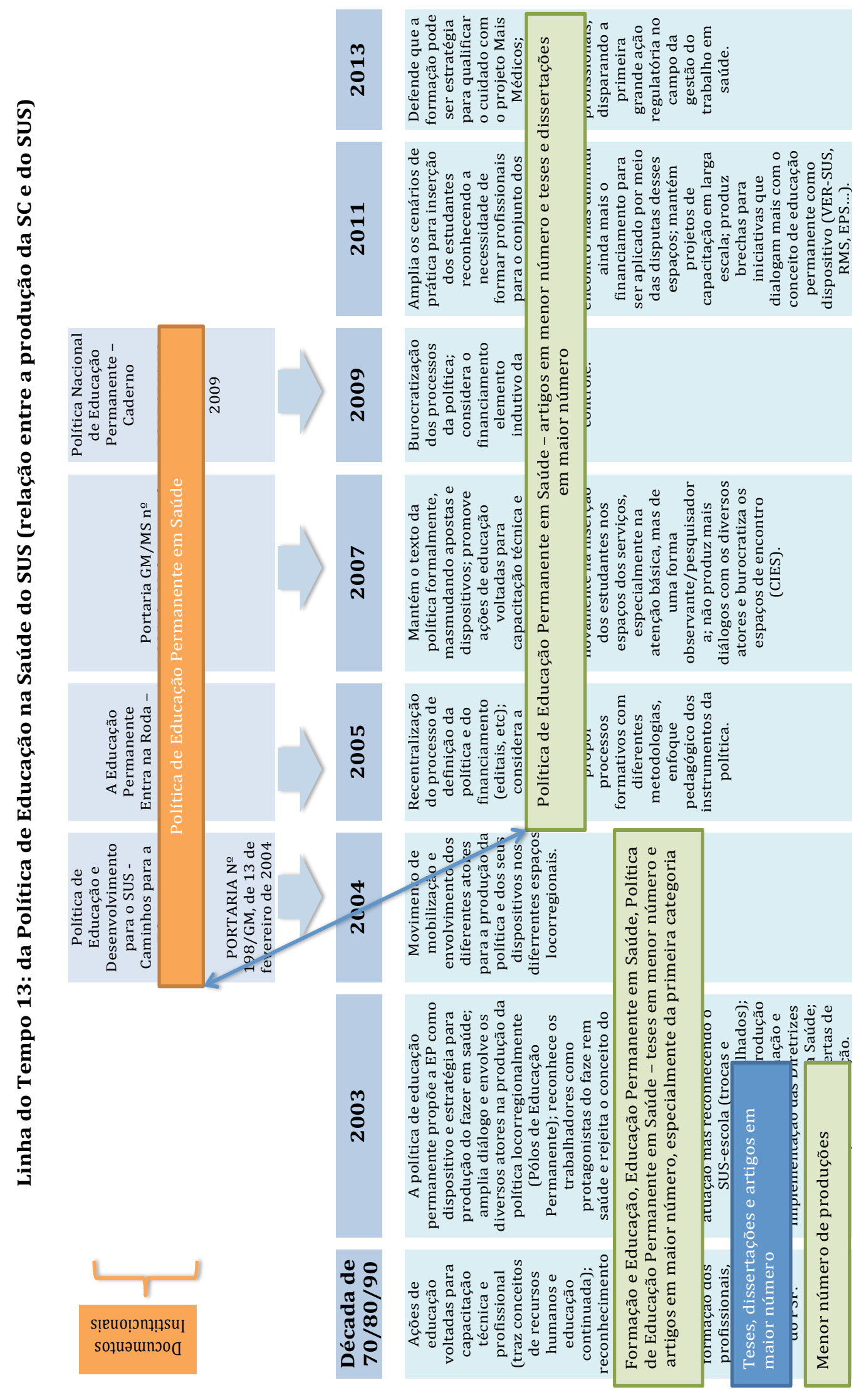


Discussão: mútuas influências entre o SUS e a Saúde Coletiva no Brasil

\section{Um pouco sobre diálogos entre o SUS e a saúde coletiva}

Além de todos os problemas já discutidos, também há problemas na produção do diálogo entre o SUS e o campo da saúde coletiva.

A produção acadêmica em saúde coletiva tem como principal meio de divulgação as revistas científicas e os livros. Somente uma pequena parte da produção de teses e disserações chega às revistas, como vimos.

A não ser alguém que tome a produção científica como objeto, os demais raramente consultarão os bancos de teses para acessar essa produção. Existe ainda o filtro das revistas, muitas delas pouco permeáveis a assuntos de extrema relevãncia para o Sistema.

Então, além do problema da dissonância e desencontro em relação às perguntas a serem respondidas, há um problema de acesso. O SUS financia pesquisas, bolsas, publicações, etc, mas pouco consegue dialogar, se apropriar, e conhecer esse conhecimento que é produzido com o seu apoio.

\section{Mútuas influências. Mútuas insuficiências}

O material analisado corresponde somente a uma parcela da produção do campo da saúde coletiva, é claro, pois analisamos somente alguns programas e algumas revistas, mas são programas referência e revistas de impacto. Então, acreditamos poder afirmar tendências gerais a partir do material estudado.

Outros estudos identificaram movimento semelhante. Pesquisa realizada por Jairnilson Silva Paim e Carmen Fontes Teixeira (2006) destaca 6 períodos de diferenciação dos temas pesquisados na saúde coletiva (p. 75-76):

1974-1979: estudos sobre determinantes econômicos, políticos e sociais da conformação de sistemas de saúde, e organização de serviços de medicina comunitária

1980-1986: estudos sobre extensão de cobertura, prática médica, modelo assistencial, ações programáticas, e programas de formação e capacitação de pessoal e experiências de integração docente-assistencial 
1987-1990: estudos sobre o ordenamento jurídico-legal dos princípios e diretrizes do projeto da reforma, descentralização, financiamento, planejamento e organização dos serviços

1991-1998: estudos sobre a definição do papel de cada esfera de governo, elaboração de instrumentos para articulação interfederativa, municipalização, programa de saúde da família, relação público-privado, promoção da saúde, modelos assistenciais, planejamento e sobre distritos sanitários

1999-2000: estudos sobre reforma do Estado/ajuste, financiamento, modelos assistenciais, relação público-privado, economia da saúde, tecnologia em saúde, processo de trabalho, análise e avaliação em saúde, sistemas de informação, descentralização, programação, monitoramento e controle social

2001-2005: estudos sobre recursos humanos, descentralização, regionalização, integralidade, saúde suplementar, financiamento, relação público-privado, informações em saúde, controle social, municipalização, expansão da atenção básica, implantação do PSF e o processo de mudança do modelo de atenção à saúde

Essa pesquisa buscou produções na base de dados bibliográficos LILACS e no banco de teses da CAPES, bem como em estudos anteriores sobre o tema. De certa forma, apresenta algumas similaridades com o que foi aqui ressaltado e ainda possibilita também relacionar uma forte influência das políticas do SUS sobre a agenda de estudos de saúde coletiva. Destacam-se algumas exceções para temas mais gerais quando são estudados no âmbito mais conceitual ou com abordagens para os desafios existentes no sistema.

\begin{abstract}
No que diz respeito à política de saúde, a maioria dos estudos realizados até o início da década de 90 apresentava uma perspectiva macro, referindo-se pouco às instituições e serviços de saúde (...) posteriormente, verificou-se uma ampliação da area com o desenvolvimento de investigações em políticas, instituições e práticas de saúde, além da maior qunatidade de estudos de avaliação em saúde (Paim e Teixeira, 2006, p. 77).
\end{abstract}

Bem, nesta tese, os dados apresentados a partir da análise de dissertações, teses e artigos também demonstram uma conexão explícita entre a produção acadêmica da saúde coletiva e o SUS. Há uma sintonia temática e até temporal entre as políticas e os estudos produzidos pelo campo.

Ou seja, a agenda temática da academia é claramente influenciada pelas políticas, suas apostas e conceitos, mas em que medida essa produção impacta, interroga, 
problematiza o instituído ou explora saídas para os problemas encontrados? Como um dos espaços de produção de textos das políticas, a saúde coletiva tem entrado na disputa ou tem cumprido um papel de difusora dos textos já produzidos?

No movimento inicial de luta pela saúde como direito, de formulação dos princípios do SUS e de produção de políticas, é nítida a influência do campo. Será que isso se mantém? Por que sim? Por que não?

No projeto original, a parte final da pesquisa incluía fazer uma oficina reunindo pesquisadores e gestores "seletos" para colocar em debate a "sensação genérica" de desencontro entre as necessidades do SUS e as pesquisas. E, assim, a autora pretendia que a tese fosse dispositivo para abrir o debate e possibilitar o repensar de encontros, diálogos e produções. Não foi possível concretizar essa oficina antes da conclusão, pretendemos realiza-la depois, mas isso não invalida a oportunidade que este estudo abre de produzir interrogações e novas conversas.

0 material analisado mostra que a imensa maioria das produções toma as políticas e os conceitos nela propostos como referência, não como objeto de análise. Ou seja, os conceitos e proposições enunciados nos textos oficiais são adotados, endossados pelos pesquisadores e raramente interrogados.

Havendo tal grau de concordância entre políticas do SUS e pesquisadores da saúde coletiva, uma primeira possibilidade de reflexão iria no sentido de melhorar o diálogo entre o SUS e o campo: quais seriam as perguntas que interessariam aos gestores/trabalhadores/usuários e por que elas não são compartilhadas com a saúde coletiva? Quais seriam os espaços de diálogo necessários à produção de uma sintonia mais fina?

Ou será que as perguntas que andam circulando são pouco produtivas para o enfrentamento de desafios? Será, então, que faltam espaços de debate crítico no âmbito do próprio SUS? Falta liberdade para interrogar as definições que orientam as políticas? Será que as políticas de indução cumprem um papel no empobrecimento dessa capacidade de interrogar, debater, propor? Será que movimentos de subordinação em cascata (gestor federal sobre estaduais e municipais; gestores estaduais sobre municipais; gestores municipais sobre trabalhadores; trabalhadores sobre usuários) também contribuem para esse empobrecimento? 
Então, a análise de políticas esboçada aqui e a análise da produção da saúde coletiva, pedem reflexões críticas nos dois campos: o da construção do SUS e o da produção da saúde coletiva.

\section{O SUS que fabricamos tem a ver com o SUS que dizemos querer?}

Do ponto de vista da mobilização de diferentes movimentos e segmentos sociais na defesa de um projeto, a situação piorou significativamente dos tempos do movimento da reforma sanitária para cá. Atualmente não se pode dizer que exista um movimento sanitário, organizado e militante. Alguns acreditam que não faria sentido um movimento assim, já que agora se trata de efetivar um sistema. Outros atribuem esse esvaziamento à concentração de esforços e energias na organização e gestão do sistema de saúde.

Nem uma coisa nem outra. Há modos de organizar o sistema, de produzir políticas que favorecem a mobilização e outros que desfavorecem. Há como ser governo sem se descolar da produção de dinâmicas sociais inventivas, mas essa é uma tarefa cada vez mais difícil com a estreitíssima margem de manobra com que os governos ditos progressistas têm sido produzidos (FEUERWERKER,2014).

Para governar mantendo a mobilização, é preciso efetivar um sistema, sim, mas em um movimento de confrontação permanente e isso exige, sim, mobilização, luta, resistência, fabricação dos atores sociais que são necessários para efetivar essas apostas.

Isso porque não existem prontos os atores que um sistema como o SUS requer. Não existem os profissionais para produzir relações cuidadoras e construir a integralidade - eles precisam ser produzidos. Não existem os secretários municipais de saúde preparados para efetivar a gestão local de modo criativo e de acordo com os contextos locais. Eles precisam ser produzidos. Não existem os espaços regionais com potência solidária para produzir a governança regional. Eles precisam ser produzidos. Não existem as escolas para formar trabalhadores que defendam esse projeto. Elas precisam ser produzidas. Não existe o saber, nem as tecnologias para atender as necessidades dos usuários numa perspectiva 
de enriquecimento de seus modos de viver. Eles precisam ser produzidos em interação com os usuários (FEUERWERKER, 2014).

Existe, sim, um contingente expressivo de atores mobilizados por tentar construir um sistema de saúde que se aproxime das proposições originais do movimento sanitário. Mas eles não têm sido convidados a participar da construção do SUS. Existem experiências interessantes e invenções. Mas não existe mais, como nos tempos pré-conquista do SUS, o debate intenso, a circulação ampla de propostas, a mobilização contínua em torno de uma disputa política e da feroz resistência às máquinas de captura.

\section{Os modelos tecnoassistenciais e a disputa pelo conceito e práticas de saúde}

A transformação dos modos de organizar a atenção à saúde vem sendo considerada indispensável para a consolidação do SUS por pelo menos dois grandes motivos. Em primeiro lugar pela necessidade de qualificar o cuidado por meio de inovações produtoras de integralidade da atenção, diversificação da utilização das tecnologias de saúde e articulação da prática dos diferentes profissionais e esferas da assistência.

Em segundo lugar, pela necessidade de adotar maneiras mais eficientes para a utilização dos recursos. Principalmente considerando que o modelo hegemônico de atenção à saúde - centrado na produção de procedimentos - implica custos crescentes, particularmente em função do envelhecimento da população, da transição epidemiológica e, sobretudo, da incorporação tecnológica orientada pela lógica do Mercado.

O conjunto de estratégias que vem sendo majoritariamente implementado para construir o SUS baseia-se na proposta de mudar o modelo tecnoassistencial a partir da atenção básica por meio da saúde da família e da ampliação da ênfase sobre a promoção à saúde.

Essa experiência tem esbarrado em problemas recorrentes, como a persistente fragmentação do cuidado por níveis de atenção, havendo grandes dificuldades para articular os diferentes pontos da rede (FEUERWERKER, 2005).

Além disso, apesar de se buscar fortalecer a programação em saúde, verifica-se amplamente a reprodução da prática clínica de pronto-atendimento na atenção 
básica. Como consequência, temos descontinuidade da atenção, dificuldade de adesão por parte dos usuários e resultados pobres no controle dos agravos crônicos.

Há significativa restrição de acesso a segmentos da atenção especializada e a métodos diagnósticos. Além disso, há dificuldades de efetivar o trabalho em equipe, persistindo o fenômeno da desresponsabilização em relação à saúde dos usuários como um todo e a perda da dimensão cuidadora dos atos de saúde.

Sucessivas tentativas de "enquadramento" dos trabalhadores e usuários a propostas estruturadas de organização das práticas e das portas de entrada à atenção à saúde têm fracassado. Dispositivos (como o acolhimento) e estratégias de suposta democratização da gestão muitas vezes se burocratizam e perdem seu sentido e potência ao longo tempo (FEUERWERKER, 2014).

Para implementar um modelo de atenção centrado nos interesses dos usuários, capaz de satisfazer suas necessidades, é preciso haver mudanças no cotidiano do fazer em saúde, na prestação das ações de saúde, na clínica realizada pelos diversos profissionais.

A escolha do desenho tecnoassistencial deve também preservar e desenvolver a autonomia das pessoas; enfrentar os preconceitos ou privilégios (garantia de igualdade na assistência); garantir o direito dos usuários e populações à informação sobre sua saúde (pessoal e coletiva); tornar conhecida a proposta "arquitetada" para a utilização da rede; incorporar, além dos saberes da saúde, as outras visões de direitos sociais na alocação de recursos e nas orientações programáticas e incentivar, ao máximo, a participação popular (BRASIL (A), 2005, p. 82).

Existem alternativas nesse sentido, implementadas por um número limitado de municípios. Nelas têm-se procurado orientar a organização dos serviços pelas necessidades de saúde, produzindo linhas de cuidado que atravessam atenção básica, especializada, ambulatorial e hospitalar. Essas experiências tem investido na produção de dispositivos de apoio e de rede - com apoio institucional, matricial, arranjos territoriais, educação permanente em saúde, por exemplo para possibilitar a produção de conexões vivas, a permanente análise crítica sobre o processo de trabalho e a constante renovação de pactos para produzir o cuidado e a ampliação/renovação das tecnologias envolvidas na atenção.

Essas alternativas, mais ousadas e flexíveis, exigem estratégias para sua gestão e implementação, que envolvem recursos de gestão do cuidado relativamente 
escassos no sistema, particularmente quando se pensa de maneira ampla em nosso país, com mais de 5500 municípios, 70\% dos quais com menos de 20 mil habitantes. E não há investimentos nesse sentido (MERHY \& FEUERWERKER, 2008).

Desde os primeiros anos de organização do SUS, em suas instâncias de decisão, os principais debates e polêmicas giraram em torno dos mecanismos de financiamento e dos arranjos de gestão. Sem se conectar ao cotidiano do mundo do trabalho e sem se colocar em diálogo com as disputas ali presentes, os gestores atuam principalmente no plano da formalidade - das regras, normas, portarias - dirigidas a atores que não existem na prática. A relação intergestores fabricou um mundo paralelo - de planos, relatórios, indicadores (e até de pactos) - que pouco se alimenta e ou alimenta da vida que acontece no cotidiano das unidades de saúde - mas que consome uma parte considerável de sua energia. Multiplicam-se as relações de subordinação do gestor federal sobre os estaduais e municipais, dos estaduais sobre os municipais, dos níveis centrais sobre os locais; dos níveis gerenciais sobre os trabalhadores; dos trabalhadores sobre os usuários. Os tempos burocráticos nunca combinam com os tempos de processos mais democráticos e participativos. Lembremos que a política é uma máquina de fabricar relações, então que projeto democrático pode ser produzido a partir de tantas relações de assujeitamento?

A democratização, a diversidade do país, a necessidade de construir respostas específicas, bem como a produção da responsabilidade local sobre a produção da saúde foram os argumentos para a descentralização. E a descentralização tem sido um dos elementos fundamentais para a vitalidade do SUS. No entanto ela é afrontada todo tempo pela persistência de um modo centralizado de fazer política (em que o gestor federal prevalece em função da concentração de poder técnico, político e financeiro). Como comentamos, os incentivos financeiros são utilizados como instrumento de subordinação. E a descentralização também é prejudicada pela ausência de políticas para fortalecer o gestor local, ampliar sua capacidade de gestão. No máximo são oferecidos cursos de capacitação (FEUERWERKER, 2005).

De modo geral, nos espaços formais de participação - conselhos e conferências no máximo, ocorre a legitimação de políticas que foram produzidas em outro lugar (em geral nas áreas técnicas do ministério ou das secretarias e depois 
acordadas nas instâncias intergestores). Parece lógico, pois como é que se poderia considerar "capazes de contribuir na formulação de políticas" as representações de atores que, em todos os outros espaços, se supõe ser necessário capacitar? Restaria a eles apenas a alternativa de defender seus interesses específicos - ou seja, um dos poucos espaços abertos para participação democrática acaba operado pelo corporativismo e pelo clientelismo. Não há organização e mobilização - entre trabalhadores e usuários - para assegurar representatividade aos representantes (com exceção dos que representam as corporações e talvez os usuários que representam portadores de doenças - mais um elemento em favor do corporativismo e do clientelismo).

A dinâmica da sociedade mudou: mais fragmentada e atravessada por ondas de mobilização específica e transitória. No pior dos casos, em pleno processo de assujeitamento pela biopolítica pela medicalização e pela máquina do capitalismo mundial.

A desconstrução desse imaginário acontece por meio de processos de desacomodação que podem ser fabricados deliberadamente ou podem acontecer ao acaso dos encontros. Processos de reflexão e autonálise em coletivos são possibilidades para produzir movimento. Essas são as apostas da educação permanente.

A mudança das práticas de saúde e a reorientação do modelo tecnoassistencial, no plano do discurso, são indicadas como fundamentais em diferentes âmbitos do SUS. Mas em termos de volume de recursos, o investimento para produzir a mudança é muito pequeno. E como não se reconhece a dinâmica micropolítica das práticas, as estratégias adotadas são em grande parte normativas, baseadas na transmissão de conhecimentos ou de estímulos materiais e financeiros. Ou seja, mesmo quando pretende mudar, as práticas políticas e de gestão adotadas majoritariamente no SUS fabricam a reprodução do que está estabelecido (FERUERWERKER, 2014).

Então, ao não enfrentar a disputa de projetos de vida em todos os campos da saúde e ao não buscar inovar as práticas de cuidado em saúde, o modelo tecnoassistencial implementado de maneira predominante no SUS vem reafirmando os conceitos e práticas hegemônicos em saúde e condenando a um gueto o espaço da atenção básica, onde se espera estar havendo a produção de práticas de saúde inovadoras.

Aos construtores do SUS, de modo geral, têm escapado o plano da micropolítica. Nas arenas de disputa que são as unidades de saúde, existem as tensões e as 
possibilidades da produção do trabalho vivo em ato nos encontros dos trabalhadores entre si, com a gestão e com os usuários. Sem interagir com esse espaço, os gestores com G governam precariamente. Iludem-se com sua potência de produzir efeitos. Depois se espantam: por que as políticas nunca são implementadas como preconizadas? E respondem: porque falta capacitação aos responsáveis pela implementação...

Mas não basta reconhecer o espaço micropolítico de produção. Há quem o reconheça (mesmo que com outro nome), mas proponha a intervenção por meio da ampliação dos controles - para aumentar a governabilidade do gestor restringindo os espaços de autonomia dos profissionais. Esses tipos de intervenção estão orientados a matar o trabalho vivo - efeito fatal sobre a possibilidade de relações cooperativas e produtoras de vida com usuários e trabalhadores. É o caso do managed care. É o caso também de gestões que não se cansam de produzir modos de controlar... (Merhy, 2002); (Cecilio, 2007)

Em função de tudo isso, o SUS é precário. É frágil e está em plena construção/desconstrução. Não há garantias de que será possível implantá-lo em sua radicalidade, pois para tanto dependemos, decisivamente, da fabricação de atores para cumprir esses papéis em novos espaços de encontro e produção das práticas e políticas de saúde. Do contrário, o SUS será reduzido ao que o neoliberalismo espera de uma política de saúde.

A construção dos espaços democráticos e dos atores necessários à construção do SUS não está plenamente contida na institucionalidade já produzida e consolidada no sistema. Novos arranjos políticos, de gestão e de participação são, portanto, indispensáveis (Merhy, 2005).

\section{E a saúde coletiva continua sustentando os compromissos que a inauguraram como campo de sabers e práticas?}

Depois de um período inicial em que vários núcleos da saúde coletiva se envolveram com a produção de alternativas para organização do SUS na prática e no plano conceitual, essa aproximação intensiva com a prática foi ficando mais restrita. 0 desafio de construir a saúde coletiva como área de pós-graduação consumiu crescentemente os esforços da maioria. E os atravessamentos que as políticas de ciência e tecnologia no país produzem também afetaram este campo. 
Em estudo de Bosi e Gastaldo (2011) é trazida a reflexão de que há um predomínio da ciência tradicional como um modelo de "boa ciência", destacando que em geral há um tendência de estudo para os resultados e não para os processos. Isso reforça o olhar para os problemas encontrados e não necessariamente para a crítica a produção dos processos que levaram a tais resultados. Também reforça que existe uma dissociação entre o que é apregoado por vários atores e o que de fato é prática científica em saúde.

\begin{abstract}
Acrescenta-se a visão de mundo hegemônica na ciência contemporânea, na qual, de forma crescente, se prioriza a produtividade e a serialidade na produção, muitas vezes sem examinar a missão que se destina. No âmbito da saúde coletiva, tal política de produtividade tem levado a que se negligencie algo cujo reconhecimento se revela como decisivo: trata-se da saúde humana. E se insistimos em adjetivar o objeto desse campo de saberes e práticas é porque julgamos ainda necessário fazê-lo, tendo em vista a necessidade de diálogo entre os distintos paradigmas que compõem o campo (Bosi e Gastaldo, 2011, p. 1199).
\end{abstract}

Submeter-se a critérios cientificistas em detrimento do compromisso e da relevância pública e social foi um dos preços que vimos pagando (CAMARGO JR, K. R., 2013, p. 1708).

Mas, talvez o principal ingrediente da perda de vitalidade intelectual da saúde coletiva tenha a ver exatamente com as acusações que, à época de sua fundação, eram dirigidas à velha saúde pública: tradicional, fechada a interrogações, fechada a perspectivas diferentes.

A saúde coletiva, apesar de ter que conviver e por para dialogar diferentes áreas de saber e de ter-se construído com base numa feroz crítica ao cartesianismo, tem pretensão de verdade. E essa pretensão de verdade está baseada na perspectiva marxista constitutiva do campo.

Do mesmo modo que no âmbito do SUS, o campo da saúde coletiva tem tido dificuldade de interrogar-se em profundidade. Se as teorias constitutivas do campo não tem sido suficientes, potentes para dar conta de explicar o mundo e contribuir para sua transformação (como eram a aspiração e o compromisso declarados da saúde coletiva), não cabem interrogações e outras buscas? Elas existem, vindo de diferentes lugares, mas são minoritárias e muitas vezes bruscamente rejeitadas. A maior parte das vezes os teóricos do campo responsabilizam os gestores pelas falhas de implementação - excesso de pragmatismo, desvios burocráticos etc. 


\section{Pensando na análise de políticas}

Como já comentado, a perspectiva predominante nos estudos de análises de política identificados era a de ciclo de políticas. Formulação, implementação, avaliação. E a maior parte das pesquisas estuda a implementação das políticas tomando os conceitos e os textos das políticas como referencial analítico. Muitos desses estudos concluem pela existência de fragilidades de implementação. Poucos interrogam a potência dos conceitos embutidos nas políticas ou os dispositivos que as políticas colocam em marcha.

Para dar um exemplo: algumas produções que tomaram como objeto de análise a política de educação permanente em saúde não percebiam descontinuidade entre os diferentes momentos da política e suas principais portarias. Isso porque no texto da portaria de 2007 estão afirmados os conceitos e declarações da portaria de 2004. Para esses autores, a política é o texto!!! O esforço extremo para fazer uma CIES funcionar ou a falta de apoio para desenvolver atividades de educação permanente que não fossem cursos eram identificadas como "problemas de implementação", insuficiência dos atores. Em nenhum momento colocavam em análise os dispositivos propostos pela política em suas diferentes fases, já comentadas no capítulo anterior.

Portanto, a interrogação não se remete a política e sim ao context em que ela é implementada. Por isso, em geral, as conclusões dos estudos e pesquisas consideram o contexto um limitador para a sua adequada implementação.

Os estudos interrogam a prática e a implementação dos textos das políticas e concluem que existem problemas e desafios, mas os autores não reconhecem que a política se produz também na prática e que os problemas identificados podem corresponder a problemas de concepção, dos dispositivos propostos, a atravessamentos societários etc.

A política é o texto e o texto é a referência fechada para orientar e organizar as práticas. A extrema dificuldade de efetivar os princípios das políticas muitas vezes são atribuídos "à distância entre teoria e prática”, mas raramente à disputa de projetos que marca o cotidiano das organizações.

Se dialogassem com certas produções do próprio campo, talvez fossem mais produtivos. A teoria do planejamento de Matus tem uso limitado na análise de políticas, no entanto, quando assumimos o conceito de que "todo mundo 
governa" e entendemos a etapa estratégica como a que de fato viabiliza o planejamento em si, talvez, possamos buscar essa similaridade com o conceito trazido por Ball. Se compreendermos que todo mundo produz política, portanto, todo mundo tem projeto e disputa por ele, compreendemos que a política é produzida em vários planos com inúmeros atravessamentos. Tal comparação é especialmente útil quando isolamos o contexto de producão de textos e que aqui foi analisado com o conjunto das políticas. A formulação dos projetos, dos planos, dos programas, das leis e das políticas, prevista pelo planejamento, de certa forma, tem alguma relação com a etapa de produção de texto aqui explorado a partir do conceito de Ball.

Essa formulação é interessante e pode dialogar com a metodologia de análise de política. Testa também considera que a saúde está inserida num contexto mais amplo e, portanto, é diretamente influenciada por vetores diferentes e sua produção é diretamente influenciada pelo contexto social, sendo assim, os atores sociais estabelecem relações de poder e a partir delas se desenvolvem ações políticas de saúde.

Os formatos estruturados e não estruturados das práticas de planejamento realizadas por sujeitos, trabalhadores e dirigentes de uma instituição de saúde, seriam uma das possíveis traduções do método, um dos componentes da capacidade de governo. As práticas de planejamento estariam dirigidas a organizar práticas de saúde, uma das formas de implementar políticas de saúde. As práticas de planejamento seriam condicionadas pela organização, caracterizada pelas estruturas e formas de organização do trabalho realizado pelos dirigentes e trabalhadores; e determinadas pelos propósitos de ambos quanto aos resultados de suas práticas: legitimação, manutenção, crescimento, mudança ou transformação. E não estariam livres de determinações mais amplas, como o papel do Estado e da história (Vilasbôas e Paim, 2012, p. 1240).

Tais formulações trazem elementos importantes para análise das políticas e fortalecem a escolha do referencial utilizado pois reforçam que existem mais elementos a serem considerados. Nessa perspectiva, é relevante considerar que a solidariedade entre os diferentes atores na produção da política é inexistente pois já um grande desequilíbrio de poder na disputa dos projetos. Assim, o conceito de Matus para o planejamento que considera que

O planejamento e a ação são inseparáveis. 0 plano é o cálculo que precede e preside a ação. Se não a preceder, o plano é inútil porque chega tarde. E se chega a tempo mas não a preside, o plano é supérfluo. Por sua vez, a ação sem cálculo que a preceda e a presida é mera improvisação (Matus, 1993, p.32). (...) o planejamento, como corpo de teoria geral, pode aplicar-se 
a qualquer atividade humana em que é necessário um esforço para alcançar um objetivo (Matus, 1993, p.10). Matus C. Política planejamento \& governo. Brasília: IPEA; 1993.

Assim, trazer esses conceitos do planejamento permite algumas reflexões. 0 postulado de coerência ajuda a saber se a idéia e a agenda proposta tem coerência, ou seja, se são viáveis, isso, teoricamente, ajuda a mapear os atores, interesses e jogos de poder e construir dispositivos potentes para viabilizarem a idéia ou a política. Esse processo faz parte do que podemos chamar de pensamento estratégico e que dialoga, de certa forma, com as idéias trazidas por Ball, mas não como referência para analisar o processo, e sim como proposta de método para apoiar o processo de produção dos textos das políticas.

A perspectiva de Ball para análise de políticas, que bebe nas ideias de Foucault e reconhece o plano micropolítico de produção do mundo, propõe uma perspectiva bem mais interessante e que obrigaria os estudos a se aproximarem das práticas (e não somente das declarações sobre as práticas) e das disputas de projeto entre os diferentes atores. Tornaria necessária a análise crítica dos textos e o mapeamento de seus vários planos de produção.

Considerando que a academia também é um ator que influencia no processso de produção dos textos da política, a pesquisa mostra que a saúde coletiva tem atuado reiterando, reafirmando as políticas vigentes. Talvez, inclusive, a saúde coletiva tenha se constituído na leitora mais cuidadosa das portarias que apresentam políticas...

A produção de conhecimento pode interferir de modo mais afirmativo no processo de produção das políticas, ainda mais num campo que se construiu para ser militante.

0 que encontramos nesta pequisa deveria, no mínimo, colocar ao campo da saúde coletiva em interrogação sobre seu papel polítco-social e os modos como o tem exercitado nos últimos anos. 


\section{Referências}

ABRASCO. PELO DIREITO UNIVERSAL À SAÚDE: Contribuição da Abrasco para os debates da VIII Conferência Nacional de Saúde. Rio de Janeiro, 1985.

AGAMBEN, Giorgio. 0 que é um dispositivo?. outra travessia, Florianópolis, n. 5, p. 9-16, jan. 2005. ISSN 2176-8552. Disponível em:

<https://periodicos.ufsc.br/index.php/Outra/article/view/12576/11743>. Acesso em: 09 Jul. 2015. doi:http://dx.doi.org/10.5007/12576.

ARMANI, Tereza Borget. Formação de Sanitaristas: cartografias de uma pedagogia da educação em saúde coletiva. Caxias do Sul, RS: Educs, 2007.

AROUCA, Sérgio. o Dilema Preventivista: contribuição para a compreensão e critica da Medicina Preventiva. São Paulo: Editora UNESP; Rio de Janeiro: Editora FIOCRUZ, 2003.

BALL, Stephen. Diretrizes Políticas Globais e Relações Políticas Locais em Educação. Currículo sem Fronteiras, v. 1, n. 2, p. 99-116, Jul/Dez, 2001.

Sociologia das políticas educacionais e pesquisa crítico-social: uma revisão pessoal das políticas educacionais e da pesquisa em política educacional. Currículo sem Fronteiras, v. 6, n. 2, p. 10-32, Jul/Dez, 2006.

What is Policy? Texts, Trajectories and Toolboxes. In: Discourse: Studies in the Cultural Politics of Education, 13:2, 10-17, DOI: 10.1080/0159630930130203, 06 jul 2006.

BALL, Stephen J.; MAINARDES, Jefferson (Orgs.). Políticas Educacionais: questões e dilemas. São Paulo: Cortez, 2011.

BARROS, Aluísio J D. Produção científica em saúde coletiva: perfil dos periódicos e avaliação pela Capes. Rev. Saúde Pública, São Paulo, v. 40, n. spe, p. 43-49, Aug. 2006 . Available from <http://www.scielo.br/scielo.php?script=sci_arttext\&pid=S0034$89102006000400007 \& \operatorname{lng}=$ en $\& n r m=$ iso $>$. access on 10 July 2015. http://dx.doi.org/10.1590/S0034-89102006000400007.

BASSINELLO, Greicelene Aparecida Hespanhol; BAGNATO, Maria Helena Salgado. Projeto larga escala: uma análise a partir da bibliografia existente. Esc. Anna Nery, Rio de Janeiro , v. 13, n. 1, p. 816-818, Mar. 2009. Available from <http://www.scielo.br/scielo.php?script=sci_arttext\&pid=S141481452009000100027\&lng=en\&nrm=iso>. access on 10 July 2015. http://dx.doi.org/10.1590/S1414-81452009000100027.

BERTOLLI FILHO, Claudio. História da saúde pública no Brasil. São Paulo: Editora Ática, 2008.

BERTUSSI, Débora; BADUY, Rossana Staevie; MERHY, Emerson Elias; FEUERWERKER, Laura Camargo Macruz. Viagem cartográfica: pelos trilhos e desvios. In: MATTOS, Ruben Araújo de; BAPTISTA, Tatiana Wargas de Farias (Orgs.). Caminhos para Análise das Políticas de Saúde. Rio de Janeiro, Agosto 2011. p. 306-321.

BOSI, Maria Lúcia Magalhães; GASTALDO, Denise. Construindo pontes entre ciência, política e práticas em saúde coletiva. Rev. Saúde Pública, São Paulo , v. 45, n. 6, p. 1197 1200, Dec. 2011. Available from <http://www.scielo.br/scielo.php?script=sci_arttext\&pid=S003489102011000600023\&lng=en\&nrm=iso>. access on 09 July 2015. http://dx.doi.org/10.1590/S0034-89102011000600023.

BOSI, Maria Lúcia Magalhães. Pesquisa qualitativa em saúde coletiva: panorama e desafios. Ciênc. saúde coletiva, Rio de Janeiro, v. 17, n. 3, p. 575-586, Mar. 2012. Available from <http://www.scielo.br/scielo.php?script=sci_arttext\&pid=S1413- 
$81232012000300002 \& \operatorname{lng}=$ en\&nrm=iso $>$. access on 10 July 2015. http://dx.doi.org/10.1590/S1413-81232012000300002.

BOURDIEU. Pierre. O esboço de uma teoria da prática. In: ORTIZ, Renato. Pierre Bourdieu: Sociologia. São Paulo: Ática, 1983a. p. 46- 81.

. O campo científico. In: ORTIZ, Renato. Pierre Bourdieu: sociologia. São Paulo: Ática, 1983b. p. 122-155.

. Sobre a televisão. Rio de Janeiro: Jorge Zahar, 1997.

. A produção da crença: contribuição para uma economia dos bens simbólicos. 2. ed. São Paulo: Zouk, 2004.

. Os usos sociais da ciência: por uma sociologia clínica do campo científico. São Paulo: Ed. UNESP, 2004.

. O poder simbólico. 8. ed. Rio de Janeiro: Bertrand Brasil, 2005.

BURLANDY, Luciene; BODSTEIN, Regina Cele de A.. Política e saúde coletiva: reflexão sobre a produção científica (1976-1992). Cad. Saúde Pública, Rio de Janeiro , v. 14, n. 3, p. 543554, July 1998. Available from <http://www.scielo.br/scielo.php?script=sci_arttext\&pid=S0102311X1998000300011\&lng=en\&nrm=iso>. access on 10 July 2015. http://dx.doi.org/10.1590/S0102-311X1998000300011.

BUSS, Paulo Marchiori. Promoção da saúde e qualidade de vida. Ciência \& Saúde Coletiva (p. 163-177). Rio de Janeiro: ABRASCO, 2000.

CAMARGO JUNIOR, Kenneth Rochel de. Apresentação: As muitas vozes da integralidade. In: PINHEIRO, Roseni; MATTOS, Ruben Araújo de (Orgs.). Os sentidos da Integralidade na atenção e no cuidado à saúde. Rio de Janeiro: UERJ, IMS: Abrasco, 2001.p. 11-16.

Biomedicina, saber \& ciência: uma abordagem crítica. São Paulo: HUCITEC, 2003.

.Produção científica: avaliação da qualidade ou ficção contábil? Cad Saúde Pública 2013; 29:1707-11.

CAMARGO JR, Kenneth Rochel de et al . Produção intelectual em saúde coletiva: epistemologia e evidências de diferentes tradições. Rev. Saúde Pública, São Paulo, v. 44, n. 3, p. 394398, jun. 2010. Disponível em <http://www.scielosp.org/scielo.php?script=sci_arttext\&pid=S003489102010000300002\&lng=pt\&nrm=iso>. acessos em 10 jul. 2015. Epub 07-Maio2010. http://dx.doi.org/10.1590/S0034-89102010005000008.

CAMPOS, Gastão Wagner de Sousa. Um balanço do processo de municipalização dos serviços de saúde no Brasil. Saúde em Debate, (28):24-7, mar. 1990.

. Modelos de atenção em saúde pública: um modo mutante de fazer saúde. Rev. Saúde em Debate, Rio de Janeiro, n. 37, Dezembro, 1992.

Um método para análise e co-gestão de coletivos. São Paulo: HUCITEC, 2000.

A saúde pública e a defesa da vida. 3. ed. São Paulo: HUCITEC, 2006a.

Reforma da Reforma: repensando a saúde. 3. ed. São Paulo: HUCITEC, 2006b.

Saúde pública e saúde coletiva: campo e núcleo de saberes e práticas. Rev. Ciência \&

Saúde Coletiva, Rio de Janeiro, v. 5, n. 2, 2000. Disponível em: 
<http://www.scielo.br/scielo.php?script=sci_arttext\&pid=S1413-

$81232000000200002 \& \operatorname{lng}=$ pt\&nrm=iso $>$. Acesso em: 26 Set 2007a.

. Reforma política e sanitária: a sustentabilidade do sus em questão?. Ciênc. saúde coletiva, Rio de Janeiro, v. 12, n. 2, p. 301-306, Apr. 2007b. Available from <http://www.scielo.br/scielo.php?script=sci_arttext\&pid=S141381232007000200002\&lng=en\&nrm=iso $>$. access on 10 July 2015. http://dx.doi.org/10.1590/S1413-81232007000200002.

CAMPOS, Francisco Eduardo de; BADUY, Rossana Staevie. Programa de Saúde da Família: Oportunidade para a transformação da Educação dos Profissionais de Saúde. In: Olho Mágico, Londrina, ano 4, abril/maio/jun 98, nº 16, p. 4-5, 1998.

CARVALHO, Sérgio Resende. Saúde coletiva e promoção da saúde: sujeito e mudança. 2. ed. São Paulo: HUCITEC, 2007.

CARVALHO, Mônica Sampaio de; SOUSA, Maria Fátima de. Como o Brasil tem enfrentado o tema provimento de médicos?. Interface (Botucatu), Botucatu , v. 17, n. 47, p. 913-

926, Dec. 2013. Available from <http://www.scielo.br/scielo.php?script=sci_arttext\&pid=S141432832013000400012\&lng=en\&nrm=iso >. access on 10 July 2015. http://dx.doi.org/10.1590/1807-57622013.0403.

CECCIM, Ricardo Burg. Equipe de saúde: a perspectiva entre-disciplinar na produção de atos terapêuticos. In: PINHEIRO, Roseni; MATTOS, Ruben Araújo de (Orgs.). Cuidado: as fronteiras da integralidade. Rio de Janeiro: HUCITEC / Abrasco, 2004. p. 259-278.

. Onde se lê "recursos humanos da saúde", leia-se "coletivos organizados de produção da saúde": desafios para a educação. In: PINHEIRO, Roseni; MATTOS, Ruben Araújo de (Orgs.). Construção social da demanda: direito à saúde, trabalho em equipe, participação e espaços públicos. Rio de Janeiro: CEPSC/UERJ: Abrasco, 2005, p.161-180.

CECCIM, Ricardo Burg; FERLA, Alcindo Antônio. Notas Cartográficas sobre a escuta e a escrita: contribuições à educação das práticas de saúde. In: PINHEIRO, Roseni; MATTOS, Ruben Araújo de (Orgs.). Construção social da demanda: direito à saúde, trabalho em equipe, participação e espaços públicos. Rio de Janeiro: IMS / UERJ - CEPESC - Abrasco, 2005. p. 253-266.

CHIGNOLA, Sandro. Sobre o dispositivo: Foucault, Agamben, Deleuze. Cadernos IHU ideias/Universidade do Vale do Rio dos Sinos, Intituto Humanitas, Unisinos. Ano 1, n. 1. São Leopoldo: Universidade do Vale do Rio dos Sinos, 2003.

COHN, Amélia. Conhecimento e prática em saúde coletiva: o desafio permanente. In: Revista Saúde e Sociedade, São Paulo, v. 1, n. 2, p. 97-109, 1992.

CORDEIRO, Hésio. A indústria da saúde no Brasil. 2. ed. Rio de Janeiro: Graal, 1985.

. O Instituto de Medicina Social e a luta pela Reforma Sanitária: Contribuição à História do SUS. PHYSIS: Revista de Saúde Coletiva, Rio de Janeiro, v. 14, n. 2, p. 343-362, 2004.

CRUZ, Marly M. Avaliação de Políticas e Programas de Saúde: contribuições para o debate. In: MATTOS, Ruben Araújo de; BAPTISTA, Tatiana Wargas de Farias (Orgs.). Caminhos para Análise das Políticas de Saúde. Rio de Janeiro, Agosto 2011. p. 181-199.

DALLEGRAVE, Daniela; KRUSE, Maria Henriqueta Luce. No olho do furacão, na ilha da fantasia: a invenção da residência multiprofissional em saúde. Interface (Botucatu), Botucatu , v. 13, n. 28, p. 213-226, Mar. 2009. Available from <http://www.scielo.br/scielo.php?script=sci_arttext\&pid=S141432832009000100018\&lng=en\&nrm=iso $>$. access on 10 July 2015. http://dx.doi.org/10.1590/S1414-32832009000100018. 
DANNER, Fernando. O sentido da biopolítica em Michel Foucault. Rev Estudos Filosóficos [online], p. 143-57, 2010. Disponível em: http://www.ufsj.edu.br/portal2repositorio/File/revistaestudosfilosoficos/art9-rev4.pdf. Acesso em 09 de julho de 2015.

DELEUZE, Gilles. 0 que é um dispositivo? In: Michel Foucault, filósofo. Barcelona: Gedisa, 1990, p. 155-161.

1942. Foucault. Tradução Claudia Sant’Anna Martins; revisão da tradução Renato Ribeiro. São Paulo: Brasiliense, 2005.

DELEUZE, G. E GUATTARI, F. Mil Platôs: capitalismo e esquizofrenia. Vol. 1. Rio de Janeiro: Ed. $34,1995 a$.

Mil Platôs: capitalismo e esquizofrenia. Vol. 2. Rio de Janeiro: Ed. 34, 1995b.

Mil Platôs: capitalismo e esquizofrenia. Vol. 3 Rio de Janeiro: Ed. 34, 1996.

DONNANGELO, Maria Cecília F.; PEREIRA, Luiz. Saúde e Sociedade. 2ª ed. São Paulo: Duas Cidades, 1979.

DREYFUS, Hubert L.; RABINOW, Paul. Michel Foucault: uma trajetória filosófica: para além do estruturalismo e da hermenêutica. $2^{\text {a }}$ ed., rev. Rio de Janeiro: Forense Universitária, 2010.

EPS EM MOVIMENTO. Educação e trabalho em saúde: a importância do saber da experiência. 2014. Disponível em: <http://eps.otics.org/material/entrada-textos/educacao-e-trabalho-emsaude-a-importancia-do-saber-da-experiencia>. Acesso em: 09 jul 2015.

EPS EM MOVIMENTO. A EPS, aprendizagem flutuante e um convite para pensar, sentir e se expressar. 2014. Disponível em: <http://eps.otics.org/material/entrada-textos/a-epsaprendizagem-flutuante-e-um-convite-para-pensar-sentir-e-se-expressar $>$. Acesso em: 09 jul 2015.

ESCOREL, S. Reviravolta na Saúde: origem e articulação do movimento sanitário. Rio de Janeiro, 1987.

ESCOREL, Sarah; TEIXEIRA, Luiz Antonio. História das políticas de saúde no Brasil de 1822 a 1963: do império ao desenvolvimentismo populista. In: GOVANELLA, Ligia et. Al. (Orgs.).

Políticas e Sistema de Saúde no Brasil. Rio de Janeiro: Editora Fiocruz, 2008. p. 333-384.

ESCOREL, Sarah; PAVUNA, Miguel Luiz. Política Naciona de Saúde 1990/1994: o “jogo da amarelinha"? Rev. Saúde em Debate, Rio de Janeiro, n. 329.

FERLA, Alcindo Antônio; JAEGER, Maria Luiza. Controle Social como processo: a participação da população na saúde e o Orçamento Participativo do estado do Rio Grande do Sul. In: FERLA, Alcindo Antônio; FAGUNDES, Sandra Maria Sales (Orgs.). Tempo de inovações: a experiência da gestão na saúde do Rio Grande do Sul. Porto Alegre: DaCasa: Escola de Saúde Pública/RS, 2002. p. 179-194.

FERLA, Alcindo Antônio. Clínica em Movimento: cartografia do cuidado em saúde. Caxias do Sul, RS: EDUCS, 2007.

FEUERWERKER, Laura Camargo Macruz. Micropolítica e saúde: produção do cuidado, gestão e formação. Porto Alegre: Rede UNIDA, 2014.

. Modelos tecnoassistenciais, gestão e organização do trabalho em saúde: nada é indiferente no processo de luta para a consolidação do SUS. Interface (Botucatu), Botucatu , v. 9, n. 18, p. 489-506, dez. 2005. Disponível em

<http://www.scielo.br/scielo.php?script=sci_arttext\&pid=S1414-

$32832005000300003 \& \operatorname{lng}=$ pt\&nrm=iso $>$. acessos

em 10 jul. 2015. http://dx.doi.org/10.1590/S1414-32832005000300003. 
FEUERWERKER, Laura Camargo Macruz; LIMA, Valeria Vernaschi de. Os paradigmas da Atenção à Saúde e da Formação de Recursos Humanos. In: BRASIL. Ministério da Saúde. Política de Recursos Humanos em Saúde: Seminário Internacional. Brasília: Ministério da Saúde, 2002.

FERREIRA NETO, João Leite et al . Usos da noção de subjetividade no campo da Saúde Coletiva. Cad. Saúde Pública, Rio de Janeiro, v. 27, n. 5, p. 831-842, May 2011. Available from <http://www.scielo.br/scielo.php?script=sci_arttext\&pid=S0102311X2011000500002\&lng=en\&nrm=iso>. access on 10 July 2015. http://dx.doi.org/10.1590/S0102-311X2011000500002.

FOUCAULT, M. A ordem do discurso. 14. ed. São Paulo: Edições Loyola, 1996.

Microfísica do Poder. 8ª ed. Rio de Janeiro: Edições Graal, 2005.

o Nascimento da clínica. 6. ed. Rio de Janeiro: Forense Universitária, 2006.

FORATTINI, Oswaldo Paulo. Pesquisa em saúde pública. Rev. Saúde Pública, 29(2): 81-88, 1995.

FRANCO, Túlio Batista; MERHY, Emerson Elias. Mapas analíticos: um olhar sobre a organização e seus processos de trabalho. 2007. Disponível em:

http://www.uff.br/saudecoletiva/professores/merhy/. Acesso em: 02 de outubro de 2010, às $12 \mathrm{~h}$.

GADELHA, Carlos Augusto Grabois. O complexo industrial da saúde e a necessidade de um enfoque dinâmico na economia da saúde. Revista Ciência \& Saúde Coletiva, Rio de Janeiro, v. 8, n. 2, p. 521-535, 2003.

. Desenvolvimento, complexo industrial da saúde e política industrial. Revista de Saúde Pública, São Paulo, v. 40, n. esp., p. 11-23, 2006.

. Desenvolvimento, complexo industrial da saúde e política industrial. Rev. Saúde

Pública, São Paulo, v. 40, n. spe, p. 11-23, Aug. 2006. Available from

<http://www.scielo.br/scielo.php?script=sci_arttext\&pid=S0034-

$89102006000400003 \& \operatorname{lng}=$ en\&nrm=iso $>$. access

on 10 July 2015. http://dx.doi.org/10.1590/S0034-89102006000400003.

GRYSCHEK, Anna Luiza de F. P. Lins et al . Projeto larga escala: uma proposta pedagógica atual. Rev. esc. enferm. USP, São Paulo, v. 34, n. 2, p. 196-201, June 2000 . Available from <http://www.scielo.br/scielo.php?script=sci_arttext\&pid=S008062342000000200009\&lng=en\&nrm=iso>. access on 10 July 2015. http://dx.doi.org/10.1590/S0080-62342000000200009.

HAESBAERT, Rogério; BRUCE, Glauco. A desterritorialização na obra de Deleuze e Guattari. GEOgraphia (UFF), Niterói, v. 7, p. 7-31, 2002.

LEAL, Mariana Bertol. Dissertação de Mestrado: Saúde Coletiva em Debate: a brasilidade de muitos encontros. Rio de Janeiro: IMS/UERJ, 2009.

LEMOS, Flávia Cristina Silveira; SILVA, Alyne Alvarez; BRÍCIO, Vilma Nonato de. Dispositivos disciplinares e biopolíticos em xeque: uma ontologia de práticas de governo. In: Anais do XV Congresso da ABRAPSO, realizado entre os dias 30 de outubro e 02 de novembro de 2009, disponível em:

http://www.abrapso.org.br/siteprincipal/images/Anais_XVENABRAPSO/291.\%20dispositivos\% 20disciplinares $\% 20 \mathrm{e} \% 20$ biopol\%CDticos $\% 20 \mathrm{em} \% 20$ xeque.pdf

LEVCOVITZ, Eduardo; LIMA, Luciana Dias de; MACHADO, Cristiani Vieira. Política de saúde nos anos 90: relações intergovernamentais e o papel das Normas Operacionais Básicas. Ciênc. saúde coletiva, São Paulo, v. 6, n. 2, p. 269-291, 2001. Available from <http://www.scielo.br/scielo.php?script=sci_arttext\&pid=S1413- 
$81232001000200002 \& \operatorname{lng}=\mathrm{en} \& \mathrm{nrm}=\mathrm{iso}>$. access on 10 July 2015. http://dx.doi.org/10.1590/S1413-81232001000200002.

LIMA, Nísia Trindade; SANTANA, José Paranaguá (Orgs.). Saúde Coletiva como compromisso: a trajetória da Abrasco. Rio de Janeiro: Ed. FIOCRUZ / Abrasco, 2006.

LIMA, Luciana Dias de et al. Descentralização e regionalização: dinâmica e condicionantes da implantação do Pacto pela Saúde no Brasil. Ciênc. saúde coletiva, Rio de Janeiro , v. 17, n. 7, p. 1903-1914, July 2012. Available from

<http://www.scielo.br/scielo.php?script=sci_arttext\&pid=S1413-

81232012000700030\&lng=en\&nrm=iso $>$. access

on 10 July 2015. http://dx.doi.org/10.1590/S1413-81232012000700030.

LUZ, Madel Therezinha. Duas questões permanentes em um século de políticas de saúde no Brasil republicano. Ciênc. saúde coletiva, Rio de Janeiro, v. 5, n. 2, p. 293-312, Jan. 2000 . Available from <http://www.scielosp.org/scielo.php?script=sci_arttext\&pid=S1413-

$81232000000200006 \& \operatorname{lng}=$ en $\&$ nrm $=$ iso $>$. access

on 10 July 2015. http://dx.doi.org/10.1590/S1413-81232000000200006.

. Notas sobre a política de produtividade em pesquisa no Brasil: consequências para a vida acadêmica, a ética no trabalho e a saúde dos trabalhadores. Política \& Sociedade: Revista de Sociologia Política, Florianópolis, v. 7, n.13, p. 205-228, 2008.

LUZ, Madel Therezinha; MATTOS, Rafael da Silva. Dimensões qualitativas na produção científica, tecnológica e na inovação em Saúde Coletiva. Ciênc. saúde coletiva, Rio de Janeiro, v. 15, n. 4, p. 1945-1953, July 2010. Available from

<http://www.scielo.br/scielo.php?script=sci_arttext\&pid=S1413-

81232010000400010\&lng=en\&nrm=iso >. access

on 10 July 2015. http://dx.doi.org/10.1590/S1413-81232010000400010.

MACHADO, Roberto. Introdução: Por uma genealogia do poder. In: FOUCAULT, Michel.

Microfísica do poder. Rio de Janeiro: Graal, 1979. p. VII-XXIII.

Foucault: a ciência e o saber. 3. ed. Rio de Janeiro: Jorge Zahar, 2006.

MACHADO, Cristiani Vieira; BAPTISTA, Tatiana Wargas de Faria; LIMA, Luciana Dias de. 0 planejamento nacional da política de saúde no Brasil: estratégias e instrumentos nos anos 2000. Ciênc. saúde coletiva, Rio de Janeiro, v. 15, n. 5, p. 2367-2382, Aug. 2010 . Available from <http://www.scielo.br/scielo.php?script=sci_arttext\&pid=S141381232010000500012\&lng=en\&nrm=iso >. access on 10 July 2015. http://dx.doi.org/10.1590/S1413-81232010000500012.

Machado J. A. Pacto de gestão na saúde: até onde esperar uma regionalização solidária e cooperativa? Rev Bras Ciênc Soc 2009; 24:105-93.

MACHADO, Francisco de Assis. Sugestões para um modelo alternative de atenção à saúde. Rev. Saúde em Debate, Rio de Janeiro, n. 31.

MAINARDES, Jefferson. Abordagem do ciclo de políticas: uma contribuição para a análise de políticas educacionais. Rev. Educação \& Sociedade 2009, v. 27, n. 94, p. 47-69, jan/abr 2006.

MAINARDES, Jefferson; FERREIRA, Márcia dos Santos; TELLO, César. Análise de políticas: fundamentos e principais debates teórico-metodológicos. In: BALL, Stephen J.; MAINARDES, Jefferson (Orgs.). Políticas Educacionais: questões e dilemas. São Paulo: Cortez, 2011. p. 143172.

MAINARDES, Jefferson; MARCONDES, Maria Inês. Entrevista com Stephen Ball: um diálogo sobre justice social, pesquisa e política educacional. Rev. Educação \& Sociedade 2009, v. 30, n. 106, p. 303-318, jan/abr 2009. 
MARCELLO, Fabiana de Amorim. O conceito de dispositivo em Foucault: mídia e produção agonística de sujeitos maternos. Educação \& Realidade, Porto Alegre (RS), v. 29, n. 1, 2004, p. 199-213.

MASCARENHAS, Rodolfo dos Santos. História da saúde pública no Estado de São Paulo. Rev. Saúde Pública, 2006; 40(1). p.3-19.

MATTOS, Ruben Araújo de. Cuidado prudente para uma vida decente. In: PINHEIRO, Roseni; MATTOS, Ruben Araújo de (Orgs.). Cuidado: as fronteiras da integralidade. Rio de Janeiro: HUCITEC / Abrasco, 2004. p. 119-132.

(Re)visitando alguns elementos do enfoque situacional: um exame crítico de algumas das contribuições de Carlos Matus. Ciênc. saúde coletiva, Rio de Janeiro , v. 15, n. 5, p. 2327 2336, Aug. 2010. Available from <http://www.scielo.br/scielo.php?script=sci_arttext\&pid=S1413$81232010000500008 \& \operatorname{lng}=$ en $\& n r m=$ iso $>$. access on 10 July 2015. http://dx.doi.org/10.1590/S1413-81232010000500008.

MATTOS, Ruben Araújo de; BAPTISTA, Tatiana Wargas de Farias (Orgs.). Caminhos para Análise das Políticas de Saúde. Rio de Janeiro, Agosto 2011.

. Sobre Política (ou o que achamos pertinente refletir para analisar políticas). In: MATTOS, Ruben Araújo de; BAPTISTA, Tatiana Wargas de Farias (Orgs.). Caminhos para Análise das Políticas de Saúde. Rio de Janeiro, Agosto 2011. p. 52-91.

MERHY, Emerson Elias. 0 capitalismo e a saúde pública: a emergência das práticas sanitárias no Estado de São Paulo. 2ª ed. Campinas: Papirus, 1987.

. A saúde pública como política: um estudo de formuladores de políticas. São Paulo: Hucitec, 1992.

A rede básica como uma construção da saúde pública e seus dilemas. In: MERHY, Emerson Elias \& ONOCKO, Rossana (Orgs.). Agir em Saúde. Um Desafio para o Público. São Paulo: Editora Hucitec. p. 197-228, 1997.

Introdução ao debate sobre os componentes da caixa de ferramentas dos gestores em saúde. Ver SUS/Brasil-Vivências e estágios na realidade do SUS do Brasil. Introdução ao debate sobre os componentes da caixa de ferramentas dos gestores em saúde. Ver SUS/BrasilVivências e estágios na realidade do SUS do Brasil, 2002.

O conhecer militante do sujeito implicado: o desafio de reconhecê-lo como saber válido. In: FRANCO, Túlio Batista; PERES, Marco Aurélio de Anselmo. (Orgs.). Acolher Chapecó: uma experiência de mudança do modelo assistencial, com base no processo de trabalho. São Paulo: HUCITEC, 2004. p. 21-45.

Debatedores. In: Ciênc. saúde coletiva [online]. 2010, vol.15, n.5, pp. 2275-2284. ISSN 1413-8123.

MERHY, Emerson E.; QUEIROZ, Marcos S.. Saúde pública, rede básica e o sistema de saúde brasileiro. Cad. Saúde Pública, Rio de Janeiro, v. 9, n. 2, p. 177-184, June 1993. Available from <http://www.scielo.br/scielo.php?script=sci_arttext\&pid=S0102-

311X1993000200009\&lng=en\&nrm=iso >. access on 10 July 2015. http://dx.doi.org/10.1590/S0102-311X1993000200009.

MERHY, Emerson Elias; MALTA, Deborah Carvalho; SANTOS, Fausto Pereira dos. Desafios para os gestores do SUS, hoje: compreender os modelos de assistência à saúde no âmbito da reforma sanitária brasileira e a potencia transformadora da gestão. In: FREESE. E. (Org.). Municípios: a gestão da mudança em saúde. Recife: UFPE, 2004. p. 45-76. 
MERHY, Emerson Elias; CAMARGO MACRUZ FEUERWERKER, Laura; BURG CECCIM, Ricardo. Educación Permanente en Salud: una Estrategia para Intervenir en la Micropolítica del Trabajo en Salud. Salud colectiva, Lanús, v. 2, n. 2, agosto 2006. Disponible en $<$ http://www.scielo.org.ar/scielo.php?script=sci_arttext\&pid=S1851$82652006000200004 \& \operatorname{lng}=$ es\&nrm=iso>. accedido en 09 jul. 2015.

MINAYO, M.C.S. 0 desafio do conhecimento: pesquisa qualitativa em saúde. 8a. Ed., São Paulo: Hucitec, 2004.

MINAYO, M.C.S.; ASSIS, S. G.; SOUZA, E. R. (org.) Avaliação por triangulação de métodos: abordagem de programas sociais. Rio de Janeiro: Editora Fiocruz, 2005.

MINISTÉRIO DA SAÚDE/BRASIL; OPAS. Contribuições pragmáticas para a organização dos recursos humanos em saúde e para a história da profissão médica no Brasil: a obra de Maria Cecília Donnangelo. Brasília, DF: Ministério da Saúde, 2004.

MINISTÉRIO DA SAÚDE/BRASIL. A Construção do SUS: Histórias da Reforma Sanitária e do Processo Participativo. Brasília, DF: Ministério da Saúde, 2006.

MINISTÉRIO DA SAÚDE/BRASIL. A Construção do SUS: Histórias da Reforma Sanitária e do Processo Participativo. Brasília, DF: Ministério da Saúde, 2006.

MINISTÉRIO DA SAÚDE/BRASIL. A Construção do SUS: Histórias da Reforma Sanitária e do Processo Participativo. Brasília, DF: Ministério da Saúde, 2006.

MINISTÉRIO DA SAÚDE/BRASIL. Departamento de Ciência e Tecnologia; Secretaria de Ciência; Tecnologia e Insumos Estratégicos. Saúde define prioridades de pesquisa. Rev. Saúde Pública, São Paulo, v. 42, n. 5, p. 974-977, Oct. 2008. Available from <http://www.scielo.br/scielo.php?script=sci_arttext\&pid=S003489102008000500027\&lng=en\&nrm=iso>. access on 10 July 2015. http://dx.doi.org/10.1590/S0034-89102008000500027.

MINISTÉRIO DA SAÚDE/BRASIL. Departamento de Ciência e Tecnologia; Secretaria de Ciência; Tecnologia e Insumos Estratégicos. Pontes e obstáculos à apropriação de resultados de estudos e pesquisas para a gestão do SUS. Rev. Saúde Pública, São Paulo , v. 42, n. 1, p. 165-

167, Feb. 2008. Available from

<http://www.scielo.br/scielo.php?script=sci_arttext\&pid=S0034-

89102008000100024\&lng=en\&nrm=iso>. access

on 10 July 2015. http://dx.doi.org/10.1590/S0034-89102008000100024.

MISHIMA, Silvana Martins; SILVA, Eliete Maria; ANSELMI, Maria Luiza; FERREIRA, Silvia Lúcia. Agentes Comunitários de Saúde: bom para o Ceará... bom para o Brasil?. Rev. Saúde em Debate, Rio de Janeiro, n. 37, Dezembro, 1992.

MORIN, Edgar. Ciência com consciência. 9. ed. Rio de Janeiro: Bertrand Brasil, 2005.

MOTA, André et. al. Ministério da Saúde e Organização Pan-americana da Saúde. Contribuições pragmáticas para a organização dos recursos humanos em saúde e para a história da profissão médica no Brasil: à obra de Maria Cecília Donnangelo. Brasília: Ministério da Saúde, 2004.

NEMES, Mari Inês Baptistella. Ação Programática em Saúde: recuperação histórica de uma política de programacão. In: SCHRAIBER, Lilia Bbima (org.). Programação em Saúde Hoje. São Paulo: Editora HUCITEC, 1993.

NETO, Júlio S. Müller. Descentralização e Democracia: Tópicos de um Debate. Rev. Saúde em Debate, Rio de Janeiro, n. 33.

NUNES, Everardo Duarte. Sobre a história da saúde pública: idéias e autores. Rev. Ciência e Saúde Coletiva, 5 (2): 251-264, 2000. 
Saúde coletiva: uma história recente de um passado remoto. In: CAMPOS, Gastão Wagner de Sousa et al. (Orgs.). Tratado da saúde coletiva. São Paulo: HUCITEC; Rio de Janeiro: Ed. FIOCRUZ, 2006. p. 19-40.

OLIVEIRA, Dora Lúcia de. A 'nova' saúde pública e a promoção da saúde via educação: entre a tradição e a inovação. Rev. Latino-Am. Enfermagem [online]. 2005, vol.13, n.3, pp. 423-431. ISSN 0104-1169. doi: 10.1590/S0104-11692005000300018.

OLIVEIRA, Ana de; LOPES, Alice Casimiro. A abordagem do ciclo de políticas: uma leitura pela teoria do discurso. Cadernos de Educação/FaE/PPGE/UFPel, Pelotas (38): 19-41, janeiro/abril, 2011.

Organización Panamericana de la Salud. La crisis de la salud pública: Reflexiones para el debate. Whashington, D.C.: OPAS, 1992.

PAIM, J.S. Collective health and the challenges of practice In: Pan American Health Organization The crisis of public health: reflections for the debate . Washington, 1992. p. 136-50. (Scientific Publication, 540).

PAIM, J. Bases Conceituais da Reforma Sanitária Brasileira. In: Fleury, S. (org.) Saúde e Democracia. A luta do CEBES. São Paulo: Lemos Editorial. 1997.

PAIM, Jairnilson Silva. Modelos de Atenção e Vigilância da Saúde. In: ROUQUAYROL, Maria Zélia; ALMEIDA FILHO, Naomar de. Epidemiologia \& Saúde. 6. ed. Rio de Janeiro: MEDSI/Guanabara Koogan, 2003a.

. Do "Dilema Preventivista" á Saúde Coletiva. In: AROUCA, S. O Dilema Preventivista. Contribuição para a compreensão e crítica da Medicina Preventiva. São Paulo: Editora UNESP; Rio de Janeiro: Fiocruz, 2003b. p.151-156.

Políticas de Saúde no Brasil. In: ROUQUAYROL, M.Z.; ALMEIDA FILHO, N. Epidemiologia e Saúde . 6. ed. Rio de Janeiro: MEDSI, 2003c. p.587-603.

Desafios para a Saúde Coletiva no Século XXI. 1. ed. Salvador: EDUFBA, 2006. v. 01.153 p.

Saúde coletiva como compromisso: a trajetória da abrasco. Cad. Saúde Pública, Rio de Janeiro, v. 23, n. 10, p. 2521-2522, Oct. 2007. Available from

<http://www.scielo.br/scielo.php?script=sci_arttext\&pid=S0102-311X2007001000030\&lng=en\&nrm=iso>. access on 15 July 2015. http://dx.doi.org/10.1590/S0102-311X2007001000030.

Reforma Sanitária Brasileira: contribuição para a compreensão e crítica. Salvador: EDUFBA, Rio de Janeiro: FIOCRUZ, 2008.

PAIM, Jairnilson Silva; ALMEIDA FILHO, Naomar de. Saúde Coletiva: uma "nova saúde pública" ou campo aberto a novos paradigmas? Revista de Saúde Pública, São Paulo, v. 32, n. 4, p. 299-316, 1998.

. A crise da saúde pública e a utopia da saúde coletiva. Salvador: Casa da Qualidade Editora, 2000.

PAIM, Jairnilson Silva; TEIXEIRA, Carmen Fontes. Configuração institucional e gestão do Sistema Único de Saúde: problemas e desafios. Ciênc. saúde coletiva, Rio de Janeiro, v. 12, supl. p. 1819-1829, Nov. 2007. Available from <http://www.scielo.br/scielo.php?script=sci_arttext\&pid=S141381232007000700005\&lng=en\&nrm=iso >. access on 09 July 2015. http://dx.doi.org/10.1590/S1413-81232007000700005.

. Política, planejamento e gestão em saúde: balanço do estado da arte. Rev. Saúde Pública, São Paulo, v. 40, n. spe, p. 73-78, Aug. 2006. Available from <http://www.scielo.br/scielo.php?script=sci_arttext\&pid=S0034- 
$89102006000400011 \& \operatorname{lng}=$ en\&nrm=iso $>$. access on 09 July 2015. http://dx.doi.org/10.1590/S0034-89102006000400011.

PASSOS, Eduardo; BARROS, Regina Benevides de. A construção do plano da clínica e a Transdisciplinariedade. In: Revista Psicologia: Teoria e Pesquisa, Brasília, v. 16, n. 1, p. 71-79, 2000.

PASSOS, Eduardo; KASTRUP, Virgínia; ESCÓSSIA, Liliana da (Orgs.). Pistas do método da cartografia: Pesquisa-intervenção e produção de subjetividade. Porto Alegre: Sulina, 2012.

PITTA, Aurea Maria da Rocha; MEIRA, Roseana. Comunicação social em saúde e modelo assistencial: do dicurso médico hegemônico ao discurso da integralidade: uma introdução à discussão de modelos. Rev. Saúde em Debate, Rio de Janeiro, n. 32.

POPKEWITZ, Thomas S. História do currículo, regulação social e poder. In: SILVA, Tomaz T. (Org.). 0 sujeito da educação. Petrópolis: Vozes, 1994. p. 173-210.

REZENDE, Mônica de; BAPTISTA, Tatiana Wargas de Faria. A Análise da Política proposta por Ball. In: MATTOS, Ruben Araújo de; BAPTISTA, Tatiana Wargas de Farias (Orgs.). Caminhos para Análise das Políticas de Saúde. Rio de Janeiro, Agosto 2011. p. 173-180.

ROSEN, George. Da Polícia Médica à Medicina Social. Rio de Janeiro: Graal, 1979.

SANTOS, Boaventura de Sousa. Introdução a uma ciência pós-moderna. 4. ed. Rio de Janeiro: Graal, 2003.

. Um discurso sobre as ciências. 4. ed. São Paulo: Cortez, 2006a.

(Org.). Conhecimento prudente para uma vida decente: "Um discurso sobre as ciências" revisitado. 2. ed. São Paulo: Cortez, 2006b.

SANTOS, Lenir; ANDRADE, Luiz Odorico Monteiro de. Redes interfederativas de saúde: um desafio para o SUS nos seus vinte anos. Ciênc. saúde coletiva, Rio de Janeiro, v. 16, n. 3, p. 1671-1680, Mar. 2011. Available from <http://www.scielo.br/scielo.php?script=sci_arttext\&pid=S1413$81232011000300002 \& \operatorname{lng}=$ en\&nrm=iso $>$. access on 10 July 2015. http://dx.doi.org/10.1590/S1413-81232011000300002.

SANTOS, Nelson Rodrigues dos. Os repasses federais e a descentralização da gestão, controle e avaliação. Saúde em Debate, Rio de Janeiro, n. 31, Março 1991, Cebes.

SILVA JUNIOR, Aluísio Gomes da. Modelos Tecnoassistenciais em saúde: o debate no campo da Saúde Coletiva. São Paulo: Editora HUCITEC, 2006.

SILVA, Guilherme Rodrigues. PREFÁCIO. In: AROUCA, Sérgio. 0 dilema preventivista: contribuição para a compreensão e crítica da medicina preventiva. São Paulo: Ed. UNESP; Rio de Janeiro: Ed. FIOCRUZ, 2003. p. 13-20.

SILVA, Joana Azevedo da; DALMASO, Ana Sílvia Whitaker. Agente Comunitário de Saúde: o ser, o saber, o fazer. Rio de Janeiro: Editora FIOCRUZ, 2002.

SILVA, Livia Angeli; CASOTTI, Cezar Augusto; CHAVES, Sônia Cristina Lima. A produção científica brasileira sobre a Estratégia Saúde da Família e a mudança no modelo de atenção. Ciênc. saúde coletiva, Rio de Janeiro, v. 18, n. 1, p. 221-232, Jan. 2013. Available from <http://www.scielo.br/scielo.php?script=sci_arttext\&pid=S141381232013000100023\&lng=en\&nrm=iso >. access on 10 July 2015. http://dx.doi.org/10.1590/S1413-81232013000100023.

SOUSA, Maria de Fátima de. A cor-agem do PSF. São Paulo: Hucitec, 2001. 
SOUZA, Renilson Rehem de. A regionalização no contexto atual das políticas de saúde. Ciênc. saúde coletiva, São Paulo, v. 6, n. 2, p. 451-455, 2001. Available from <http://www.scielo.br/scielo.php?script=sci_arttext\&pid=S141381232001000200014\&lng=en\&nrm=iso $>$. access on 10 July 2015. http://dx.doi.org/10.1590/S1413-81232001000200014.

STASSUN, Cristian Caê Seemann; ASSMANN, Selvino José. Dispositivo: Fusão de objeto e método de pesquisa em Michel Foucault doi: 10.5007/1984-8951.2010 v11n99p72. Cadernos de Pesquisa Interdisciplinar em Ciências Humanas, v. 11, n. 99, p. 72-92, 2010.

STOTZ, E.N. Trabalhadores, direito à saúde e ordem social no Brasil. São Paulo Perspec., v.17, n.1, p.25-33, 2003.

TEIXEIRA, Carmem Fontes. Políticas de saúde no Brasil: situação atual e desafios estratégicos. Saúde em Debate, n.35, p.4-7, 1987.

. A mudança do modelo de atenção à saúde no SUS: desatando nós, criando laços. In: TEIXEIRA, Carmem Fontes; SOLLA, Jorge Pereira. Modelo de atenção à saúde: promoção, vigilância e saúde da família. Salvador: EDUFBA, 2006. p. 19-58.

., Julho/92. Políticas de saúde no Brasil - Situação atual e desafios estratégicos. Revista Saúde em Debate, $n^{\circ}$ 35, julho, CEBES, 1992.

., (Org.). Planejamento em saúde : conceitos, métodos e experiências. Salvador : EDUFBA, 2010a.

.. Enfoques Teórico-Metodológicos Do Planejamento Em Saúde. In: TEIXEIRA, Carmen Fontes (Org.). Planejamento em saúde : conceitos, métodos e experiências. Salvador : EDUFBA, 2010b. p. 17-32.

TEIXEIRA, Carmem Fontes; PAIM, Jairnilson Silva; VILASBOAS, Ana Luiza. SUS, modelos assistenciais e vigilância da saúde. Inf. Epidemiol. Sus, Brasília , v. 7, n. 2, jun. 1998

. Disponível em <http://scielo.iec.pa.gov.br/scielo.php?script=sci_arttext\&pid=S0104-

$16731998000200002 \& \operatorname{lng}=p t \& n r m=i s o>$. acessos

em 10 jul. 2015. http://dx.doi.org/10.5123/S0104-16731998000200002.

TEIXEIRA, Carmen Fontes. Municipalização da saúde: os caminhos do labirinto. Rev. bras.

enferm., Brasília, v. 44, n. 1, p. 10-15, Mar. 1991. Available from

<http://www.scielo.br/scielo.php?script=sci_arttext\&pid=S0034-

$71671991000100003 \& \operatorname{lng}=$ en\&nrm=iso $>$. access

on 10 July 2015. http://dx.doi.org/10.1590/S0034-71671991000100003.

TRINDADE, Nisia; SANTANA, José Paranaguá de (Orgs.). Saúde Coletiva como compromisso: a trajetória da Abrasco. Rio de Janeiro: Ed. FIOCRUZ, 2006.

TURATO, Egberto Ribeiro. Métodos qualitativos e quantitativos na área da saúde: definições, diferenças e seus objetos de pesquisa. Rev. Saúde Pública, São Paulo, v. 39, n. 3, p. 507-

514, June 2005. Available from

<http://www.scielo.br/scielo.php?script=sci_arttext\&pid=S0034-

$89102005000300025 \& \operatorname{lng}=$ en\&nrm=iso $>$. access

on 10 July 2015. http://dx.doi.org/10.1590/S0034-89102005000300025.

UGA, Maria Alícia et al . Descentralização e alocação de recursos no âmbito do Sistema Único de Saúde (SUS). Ciênc. saúde coletiva, Rio de Janeiro, v. 8, n. 2, p. 417-437, 2003 . Available from <http://www.scielo.br/scielo.php?script=sci_arttext\&pid=S1413-

81232003000200008\&lng=en\&nrm=iso >. access

on 10 July 2015. http://dx.doi.org/10.1590/S1413-81232003000200008.

VASCONCELLOS, Maria da Penha Costa; SIQUEIRA, Arnaldo Augusto Franco de. Uma contribuição à saúde pública no Brasil: centro de educação permanente em saúde pública. In: Saúde em Debate, Londrina, 52: 18-23, setembro, 1996. 
VASCONCELOS, Silvia Cypriano de. Dissertação de Mestrado. A Problemática do Financiamento da Atenção Básica nos municípios no período do Pacto pela Saúde (2006-2010): o caso do Estado da Bahia. São Paulo: FSP/USP, 2013.

VIACAVA, Francisco. Produção científica dos cursos de pós-graduação em Saúde Coletiva no período 1998-2006. Ciênc. saúde coletiva, Rio de Janeiro, v. 15, n. 4, p. 1977-1988, July 2010 . Available from <http://www.scielo.br/scielo.php?script=sci_arttext\&pid=S141381232010000400013\&lng=en\&nrm=iso>. access on 09 July 2015. http://dx.doi.org/10.1590/S1413-81232010000400013.

VIANA, Ana Luiza D'Ávila; ELIAS, Paulo Eduardo M. Saúde e desenvolvimento. Revista Ciência \& Saúde Coletiva [online], Rio de Janeiro, v. 12, suppl., p. 1765-1777, 2007.

VIANA, Ana Luiza DÀvila; IBAÑEZ, Nelson; ELIAS, Paulo Eduardo Mangeon; LIMA, Luciana Dias de; ALBUQUERQUE, Mariana Vercesi de; IOZZI, Fabíola Lana. Novas perspectivas para a regionalização da saúde. São Paulo em Perspectiva, v. 22, n. 1, p. 92-106, jan./jun. 2008.

VIANA, Ana Luiza D'Ávila; LIMA, Luciana Dias de; OLIVEIRA, Roberta Gondim de. Descentralização e federalismo: a política de saúde em novo contexto - lições do caso brasileiro. Ciênc. saúde coletiva, São Paulo, v. 7, n. 3, p. 493-507, 2002 . Available from <http://www.scielo.br/scielo.php?script=sci_arttext\&pid=S1413$81232002000300008 \& \operatorname{lng}=e n \& n r m=i s o>$. access on 10 July 2015. http://dx.doi.org/10.1590/S1413-81232002000300008. 
ANEXO 1: Parecer do COEP/FSP/USP

FACULDADE DE SAÚDE
PÚBLICA DA UNIVERSIDADE Platoforma
DE SÃO PAULO

PARECER CONSUBSTANCIADO DO CEP

\section{DADOS DO PROJETO DE PESQUISA}

Título da Pesquisa: SAÚDE COLETIVA E SUS: análise sobre as mútuas influências entre o campo e o sistema de saúde no Brasil

Pesquisador: Mariana Bertol Leal

Área Temática:

Versão: 2

CAAE: 09846812.0 .0000 .5421

Instituição Proponente: Faculdade de Saúde Pública da Universidade de São Paulo - FSP/USP

Patrocinador Principal: Financiamento Próprio

\section{DADOS DO PARECER}

Número do Parecer: 193.050

Data da Relatoria: 01/02/2013

\section{Apresentação do Projeto:}

Pesquisa qualitativa referente a estudo de doutorado que se propõe a um aprofundamento a partir do mestrado da mesma proponente, tendo como objeto as relações (articulações e interseções) que se estabelecem entre o campo da Saúde Coletiva e o Sistema Único

de Saúde.

Objetivo da Pesquisa:

Analisar as interações entre o campo da Saúde Coletiva e o Sistema Único de Saúde (SUS) na construção de suas agendas.

Avaliação dos Riscos e Benefícios:

foram adequados nesta versão de projeto e do TCLE

Comentários e Considerações sobre a Pesquisa:

Pesquisa relevante, com embasamento teórico pertinente, passível de uma boa execução.

Enquanto metodologia se caracteriza como uma investigação qualitativa exploratória que obterá evidências por meio de pesquisa documental, entrevistas com especialistas de Saúde Coletiva e realização de oficina(s) com sanitaristas, indicados por entrevistados.

Considerações sobre os Termos de apresentação obrigatória:

O TCLE foi adequado conforme solicitação anterior.

Endereço: Av. Doutor Arnaldo, 715

Bairro: Cerqueira Cesar CEP: $01.246-904$

UF: SP Município: SAO PAULO

Telefone: (11)3061-7779 Fax: (11)3061-7742 E-mail: coep@fsp.usp.br 
FACULDADE DE SAÚDE

PÚBLICA DA UNIVERSIDADE DE SÃO PAULO

\section{Recomendações:}

aprovar

Conclusões ou Pendências e Lista de Inadequações:

projeto apto para execução.

Situação do Parecer:

Aprovado

Necessita Apreciação da CONEP:

Não

Considerações Finais a critério do CEP:

SAO PAULO, 04 de Fevereiro de 2013

Assinador por:

Claudio Leone

(Coordenador)

UF: SP Município: SAO PAULO

Telefone: (11)3061-7779 Fax: (11)3061-7742 


\section{ANEXO 2: Página Inicial do Currículo Lattes da Autora}

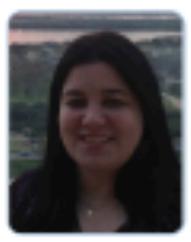

\section{Mariana Bertol Leal}

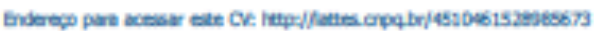

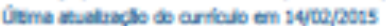

graducu-se na primeira turma do primeiro arso de Saúde Coletiva do Bresil, recebendo o titulo de bacharel em Administraçao de Satemas e Servicos de Sajde pela Universidade Estadual do Rio Grande do Sul - UERGS (2005), se deslcou ao Mestrado en Saíde Coletiva, na área de politica, planejamento e avaliaşo en sajde, no Instituto de Medidina Soclal da Universidade do Estado do Rio de Janeiro - UCRJ (condus\$o em abril de 2009), estudando o tema da constituiģo do campo dentifico da Saúde Coletiva no Brasi. Ahualmente esta finalizando o Doutorado en Saúde Pública na Faculdade de Saíde Pública na Universidade de Săo Paulo - USP, pesquisando a relaço entre o campo da Saúde Coletiva e a conformagão e orgarinscajo do SUS no Brasil. Teve experiênda como gestora do SUS (trabalhou na esfera federal e estadual e em servico de sajde) e deservolve pesquises e consultorias na área da Saúde, com enfase em Saúde Coletbra e Pública, atuando principalmente com o tema da gestào dos sistemas e serviços de saúde, planejamento, avaliaģöo, programaç̄o, contrictualizaçäa, gestso do trabalho bem como com a formaço e eblucaço en saide. (Tento informado palo autor)

Identificação

\begin{tabular}{|c|c|}
\hline Nome & Martana Bertal Leart? \\
\hline $\begin{array}{l}\text { Nome em cituçües } \\
\text { bibliegrifices }\end{array}$ & IEAL, Mariana Bertoli, EAL, Mascava Besto. \\
\hline Endereço & \\
\hline
\end{tabular}




\section{ANEXO 3: Página Inicial do Currículo Lattes da Orientadora}

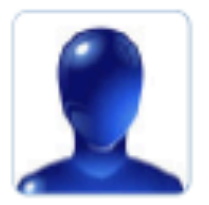

\section{Laura Camargo Macruz Feuerwerker}

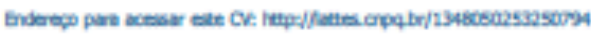

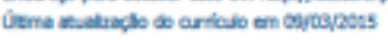

Possui graduaço em Mealdna pela Universidade de S5o Paulo (1983), mestrado en Saúde Pública pela Universidade de Säo Paulo (1997), doutorado en Saúde Pública pela Universidade de S5o Paulo (2002) e Ivre-docenda en Sajide Pública pela Universidade de S5o Paulo (2012). Atualmente é professora assodada da Facuidade de Sajde Pública da Universidade de Så Paulo do Departamento de Prática de Sajde Pública, Linha de Pesqusa Poltica e Gestăo. É colaboradora da Linha de Micropoltica do Trabalho e o Cuidado en Saúde da Pás-Graduaçón de Clinica Medica da Universidade Federal do Fio de Janeiro. No campo da produço do conhedinento, atua principalmente nos seguintes temas: politicas pública na área da gestâo, da produçăo do auidado e do trabalo em saúde, educaço de profissionais de saide. Na extersjio, desenvolve atbidades de apoio a educaço permanerte e ao desenvolvimento da gestô junto a secretarias municipais de sajde e as ministerio da sajde. (Terto informado palo autor)

\section{Identificação}

\begin{tabular}{|c|c|}
\hline Nome & Laun Camargo Macur Peverwaker \\
\hline $\begin{array}{l}\text { Nome em ditap̧es } \\
\text { bibliegrifices }\end{array}$ & 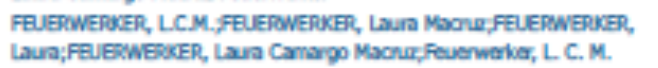 \\
\hline \multicolumn{2}{|l|}{ Endereşo } \\
\hline Enderepo hrofisional & 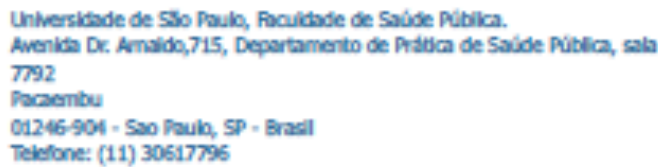 \\
\hline
\end{tabular}

